\title{
INFLUÊNCIA DA ADULTERAÇÃO DE COMBUSTÍVEIS NO DESEMPENHO E NA VIDA ÚTIL DE MOTORES DE COMBUSTÃO INTERNA DE IGNIÇÃO POR FAÍSCA DE PEQUENO PORTE UTILIZADOS EM MOTOCICLETAS
}

CONSULTA

FMP-163

Ed.rev. 


\section{INFLUÊNCIA DA ADULTERAÇÃO DE COMBUSTÍVEIS NO DESEMPENHO E NA VIDA ÚTIL DE MOTORES DE COMBUSTÃO INTERNA DE IGNIÇÃO POR FAÍSCA DE PEQUENO PORTE UTILIZADOS EM MOTOCICLETAS}

Trabalho de Conclusão de Curso apresentado à Escola Politécnica da Universidade de São Paulo para obtenção do Título de Mestre Profissional em Engenharia Automotiva.

Área de Concentração:

Engenharia Automotiva

Orientador:

Prof. Dr. Maurício Assumpção Trielli 
Este exemplar foi revisado e alterado em relação à versão original, sob responsabilidade única do autor e com a anuência de seu orientador.

São Paulo, 02 de abril de 2009.

Assinatura do autor

Assinatura do orientador

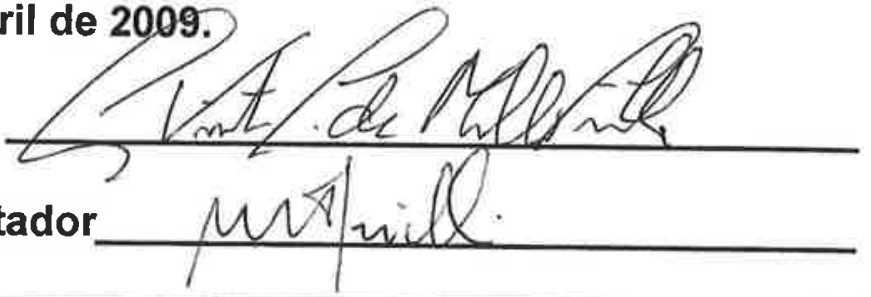

\section{FICHA CATALOGRÁFICA}

Mello Filho, Luiz Vicente Figueira de

Influência da adulteração de combustiveis no desempenho e na vida útil de motores de combustão interna de ignição por faísca de pequeno porte utilizados em motocicletas / L.V.F. de Mello Filho. -- ed.rev. -- São Paulo, 2009.

$177 \mathrm{p}$.

Dissertação (Mestrado) - Escola Politécnica da Universidade de São Paulo. Departamento de Engenharia Mecânica.

1. Combustíveis líquidos 2. Adulteração 3. Solvente 4. Etanol 5. Motor I. Universidade de São Paulo. Escola Politécnica. Depar- tamento de Engenharia Mecânica II. t. 
Dedico este trabalho aos meus pais que sempre me incentivaram a estudar. 


\section{AGRADECIMENTOS}

A minha noiva Kátia que sempre me apoiou nos estudos durante o trabalho.

Ao professor Maurício Assumpção Trielli, pela orientação e pelo constante estímulo e atenção ao longo de todo o trabalho.

A todos os colaboradores da Yamaha que diretamente e indiretamente me apoiaram, principalmente aqueles que permitiram e disponibilizaram os recursos humanos, materiais e financeiros, além de todo o tempo necessário na pesquisa, planejamento e execução do experimento. Sem essa oportunidade, o trabalho não teria sido concretizado.

A Chevron Brasil Ltda. pelas análises de óleo ao longo de todo o experimento.

E a todos que colaboraram direta ou indiretamente, na execução deste trabalho. 
O conhecimento é um tesouro, mas a prática é a chave para ele.

(Thomas Fuller) 


\section{RESUMO}

Este trabalho tem como principal objetivo mostrar os efeitos do uso de gasolina adulterada em motores de pequena cilindrada em seus desempenhos e durabilidades. Para tanto, foram realizados ensaios comparativos em três motores carburados de aplicação em motocicletas, de mesmas séries. Estes motores consumiram gasolina $\mathrm{C}$, padrão brasileiro de combustível para motores de ignição por faísca, e misturas desta gasolina com etanol hidratado carburante e solvente $\mathrm{C}-9$. Os resultados mostram alterações de desempenho, nas concentrações de gases poluentes produzidos e nos níveis de deterioração.

Palavras-chave: Combustíveis líquidos. Adulteração. Solvente. Etanol. Motor. 


\section{ABSTRACT}

This work has as main aim to show the effects of the use of the out of specification fuels in performance and durability of the low volumetric displacement engines. So, it was carried out comparative tests in three similar engines, equipped with carburetors as fuel metering arrangement, applied in motorcycles. These engines worked with standard gasoline $\mathrm{C}$, Brazilian reference fuel to spark ignition engines and blends containing hydrated ethanol and C-9 solvent. The results show changes in performance, in the pollutant gases concentration productions and deterioration levels.

Keywords: Liquid fuels. Adulteration. Solvent. Ethanol. Engine. 


\section{LISTA DE ILUSTRAÇÕES}

Figura 1 - Figura esquemática de duas superfícies em um movimento relativo abaixo das condições limites de lubrificação (HEYWOOD, 1988) 20

Figura 2 - Figura esquemática do guia da válvula, retentor e haste da válvula (PUBLICAÇÃO YAMAHA, 2001) 22

Figura 3 - Figura esquemática da distribuição de pressão no filme de óleo lubrificante no tempo de expansão, corte longitudinal (HEYWOOD, 1988) 22

Figura 4 - Figura esquemática da distribuição de pressão no filme de óleo lubrificante no virabrequim ao longo da rotação do motor (HEYWOOD, 1988) ......... 23

Figura 5 - Respiro do cárter do motor (PUBLICAÇÃO YAMAHA, 2000) ….............. 45

Figura 6 - Filtro de ar (PUBLICAÇÃO YAMAHA, 2000) …................................... 45

Figura 7 - Vista lateral direita do sistema de lubrificação do motor (PUBLICAÇÃO

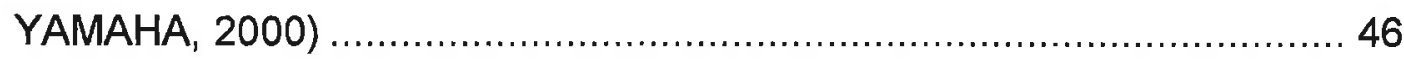

Figura 8 - Vista frontal do sistema de lubrificação do motor (PUBLICAÇÃO YAMAHA, 2000) 47

Figura 9 - Vista explodida do carburador (PUBLICAÇÃO YAMAHA, 2000) ............ 48

Figura 10 - Vedação das válvulas (PUBLICAÇÃO YAMAHA, 2000) ...................... 49

Figura 11 - Medição da pressão de compressão do motor (PUBLICAÇÃO YAMAHA, 2000) 50

Figura 12 - Válvulas de admissão do motor E25 (esquerda), motor C-9 (centro) e motor E40 (direita)... 99

Figura 13 - Válvulas de escape do motor E25 (esquerda), motor C-9 (centro) e motor E40 (direita) 99

Figura 14 - Câmara de combustão do motor E25 (esquerda), motor C-9 (centro) e motor E40 (direita) 100

Figura 15 - Vista superior do pistão motor E25 (esquerda), motor C-9 (centro) e motor E40 (direita). 100

Figura 16 - Vista lateral do pistão do motor E25 (esquerda), motor C-9 (centro) e motor E40 (direita). 101

Figura 17 - Outra vista lateral do pistão do motor E25 (esquerda), motor C-9 (centro) e motor E40 (direita). 101

Figura 18 - Cilindro do motor E25 (esquerda), motor C-9 (centro) e motor E40 (direita) 
Figura 19 - Cuba do carburador do motor E25 (esquerda), motor C-9 (centro) e motor E40 (direita)

Figura 20 - Vela de ignição do motor E25 (esquerda), motor C-9 (centro) e motor E40 (direita). 102

Figura A1 - Comprimento da mola da válvula (PUBLICAÇÃO YAMAHA, 2000) ........ I

Figura A2 - Diâmetro interno do guia da válvula (PUBLICAÇÃO YAMAHA, 2000) .... I

Figura A3 - Dimensões do came do comando de válvulas (PUBLICAÇÃO YAMAHA, 2000)

Figura A4 - Diâmetro externo do pino do balancim (PUBLICAÇÃO YAMAHA, 2000). I

Figura A5 - Diâmetro interno do cilindro (PUBLICAÇÃO YAMAHA, 2000) ............... II

Figura A6 - Diâmetro do pistão (PUBLICAÇÃO YAMAHA, 2000) ........................... II

Figura A7 - Diâmetro interno do pino do pistão (PUBLICAÇÃO YAMAHA, 2000) ..... II

Figura A8 - Folga dos anéis no pistão (PUBLICAÇÃO YAMAHA, 2000) .................. III

Figura A9 - Folga dos anéis no cilindro (PUBLICAÇÃO YAMAHA, 2000) ............... III

Figura A10 - Folga entre a biela e o virabrequim (PUBLICAÇÃO YAMAHA, 2000).. III

Figura A11 - Distância entre os contrapesos (PUBLICAÇÃO YAMAHA, 2000)........ III

Figura A12 - Folga da bomba trocoidal (PUBLICAÇÃO YAMAHA, 2000) ................. IV

Figura A13 - Ajuste da bóia do carburador (PUBLICAÇÃO YAMAHA, 2000)............ IV 


\section{LISTA DE GRÁFICOS}

Gráfico 1 - Concentração de $\mathrm{HC}, \mathrm{CO}$ e NO no escape de um motor convencional de ignição por faísca, sem pós-tratamento, em funcionamento com gasolina em função da relação ar-combustível (HEYWOOD, 1988) 10

Gráfico 2 - Concentrações de $\mathrm{NO}$ e $\mathrm{NO}_{2}$ no escapamento de um motor de ignição por centelha (HEYWOOD, 1988)

Gráfico 3 - Variação da emissão de CO com onze combustíveis em diferentes relações de ar-combustível (HEYWOOD, 1988) 15

Gráfico 4 - Classificação SAE dos óleos multi-viscosos em função da temperatura (PUBLICAÇÃO YAMAHA, 2007) 18

Gráfico 5 - Pacote típico de aditivos (BENFAREMO, 1991) 19

Gráfico 6 - Proporção de não conformidades apresentadas no período de janeiro de 2006 a novembro de 2008 (ANP, 2008) 29

Gráfico 7 - Boletim mensal de não conformidades apresentadas no período de janeiro de 2006 a novembro de 2008 (ANP, 2008) 30

Gráfico 8 - Efeito da concentração de oxigenados na pressão de vapor de misturas com gasolina (OWEN et al., 1990) 33

Gráfico 9 - Tolerância de água na mistura de metanol e etanol com uma gasolina com $26 \%$ de aromático em volume e sem a presença de cossolvente (OWEN et al., 1990) 34

Gráfico 10 - Tolerância de água numa mistura de metanol e etanol de $10 \%$ na gasolina, com diferentes quantidades de aromáticos (OWEN et al., 1990). 35

Gráfico 11 - Efeito do cossolvente na tolerância de água na mistura de metanol e etanol com $26 \%$ de aromáticos na gasolina (OWEN et al., 1990). 35

Gráfico 12 - Influência dos oxigenados e aditivos na limpeza do sistema de admissão

(OWEN et al., 1990) 36

Gráfico 13 - Comparativo de curvas de destilação para gasolina formulada com solventes e Gasolina tipo "C" comum (ALMEIDA et al, 2003) ................. 41

Gráfico 14 - Normalização dos três motores ......................................................6 66

Gráfico 15 - Levantamento das curvas de potência e torque do motor 1 ................68 68

Gráfico 16 - Levantamento das curvas de potência e torque do motor 2 ................ 70

Gráfico 17 - Levantamento das curvas de potência e torque do motor 3 .............. 71

Gráfico 18 - Emissão dos gases de escape $\mathrm{CO}_{2}, \mathrm{HC}$ e $\mathrm{CO}$ do motor 1 ................ 75 
Gráfico 19 - Emissão dos gases de escape $\mathrm{CO}_{2}, \mathrm{HC}$ e $\mathrm{CO}$ do motor 2 ................. 77

Gráfico 20 - Emissão dos gases de escape $\mathrm{CO}_{2}, \mathrm{HC}$ e $\mathrm{CO}$ do motor 3 .................. 78

Gráfico 21 - Rendimento dos motores na potência máxima .................................... 90

Gráfico 22 - Viscosidade do óleo lubrificante nos três motores durante o primeiro ciclo

Gráfico 23 - Viscosidade do óleo lubrificante nos três motores durante o segundo ciclo

Gráfico 24 - Viscosidade do óleo lubrificante nos três motores durante o terceiro ciclo

Gráfico 25 - Índice de viscosidade do óleo lubrificante nos três motores durante o primeiro ciclo

Gráfico 26 - Índice de viscosidade do óleo lubrificante nos três motores durante o segundo ciclo

Gráfico 27 - Índice de viscosidade do óleo lubrificante nos três motores durante o terceiro ciclo 93

Gráfico 28 - Número de basicidade total nos três motores durante o terceiro ciclo (mg $\mathrm{KOH} / \mathrm{g}$ ) 93

Gráfico 29 - Número de acidez total nos três motores durante o terceiro ciclo (mg $\mathrm{KOH} / \mathrm{g}$ )

Gráfico 30 - Número em ppm de alumínio encontrado nos três motores durante o terceiro ciclo 94

Gráfico 31 - Número em ppm de ferro encontrado nos três motores durante o terceiro ciclo 95

Gráfico 32 - Número em ppm de cobre encontrado nos três motores durante o terceiro ciclo 95

Gráfico 33 - Número em ppm de silício encontrado nos três motores durante o primeiro ciclo 95

Gráfico 34 - Número em ppm de silício encontrado nos três motores durante o segundo ciclo 96

Gráfico 35 - Número em ppm de silício encontrado nos três motores durante o terceiro ciclo 96

Gráfico 36 - Oxidação do óleo lubrificante encontrado nos três motores durante o primeiro ciclo em Abs/ cm 
Gráfico 37 - Oxidação do óleo lubrificante encontrado nos três motores durante o segundo ciclo em Abs/ cm .............................................................. 97

Gráfico 38 - Oxidação do óleo lubrificante encontrado nos três motores durante o

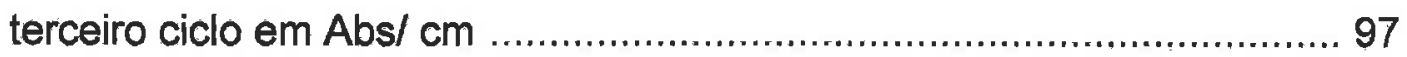

Gráfico 39 - Nitração do óleo lubrificante encontrado nos três motores durante o terceiro ciclo em Abs/ cm .............................................................. 97

Gráfico 40 - Presença de sulfatos do óleo lubrificante encontrado nos três motores durante 0 terceiro ciclo em Abs/ cm .................................................. 98 


\section{LISTA DE TABELAS}

Tabela 1 - Especificação da Gasolina Comum tipo C. Portaria ANP n 309 de $27 / 12 / 2001$

Tabela 2 - Especificação do AEAC. Portaria ANP n 36 de 06/12/2005 .............. 32

Tabela 3 - Especificação do AEHC. Portaria ANP n 36 de 06/12/2005

Tabela 4 - Comparação da destilação e a octanagem da Gasolina C com alguns tipos de solventes (ANP, 1999)

Tabela 5 - Curva de destilação do solvente AB9 (TAKESHITA, 2006) ................. 42

Tabela 6 - Amaciamento dos três motores com gasolina E25 ............................ 54

Tabela 7 - Durabilidade dos três motores com os respectivos combustíveis. ....... 55

Tabela 8 - Mistura dos combustíveis testados ................................................ 61

Tabela 9 - Dados da cromatografia em fase gasosa da mistura C-9 ...................62 62

Tabela 10 - Potência dos motores em porcentagem........................................ 63

Tabela 11 - Análise estatística do levantamento da curva de potência em \% (usando a distribuição t de Student) ......................................................... 63

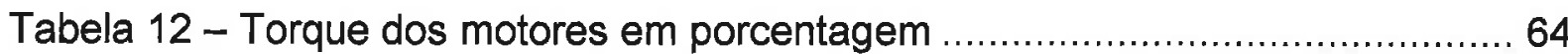

Tabela 13 - Análise estatística do levantamento da curva de torque em \% (usando a

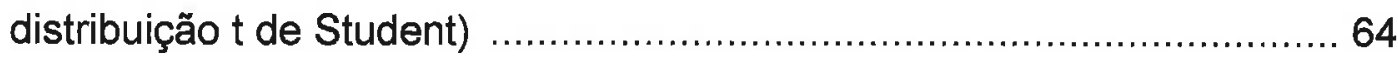

Tabela 14 - Consumo específico de combustível dos motores em $\mathrm{g} / \mathrm{kW} . \mathrm{h}$............ 65

Tabela 15 - Análise estatística do levantamento da curva do consumo específico de combustivel em $\mathrm{g} / \mathrm{kW} . \mathrm{h}$ (usando a distribuição t de Student) .................6 65

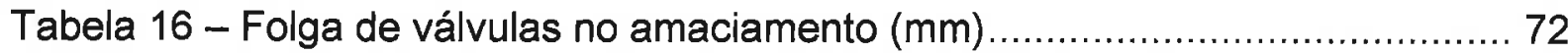

Tabela 17 - Folga de válvulas no primeiro ciclo durabilidade $(\mathrm{mm})$...................... 72

Tabela 18 - Folga de válvulas no segundo ciclo durabilidade $(\mathrm{mm})$.................... 73

Tabela 19 - Folga de válvulas no terceiro ciclo durabilidade $(\mathrm{mm})$....................... 73

Tabela 20 - Folga do eletrodo da vela de ignição $(\mathrm{mm})$................................ 73

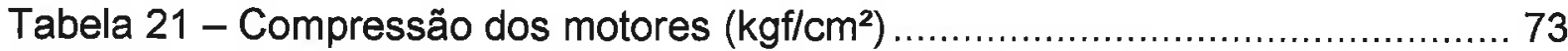

Tabela 22 - Consumo de óleo dos motores após o primeiro ciclo em gramas e gramas por hora

Tabela 23 - Consumo de óleo dos motores após o segundo ciclo em gramas e gramas por hora

Tabela 24 - Consumo de óleo dos motores após o terceiro ciclo em gramas e gramas por hora 
Tabela 25 - Valor $\lambda$ do motor E25 na rotação de potência máxima 85

Tabela 26 - Valor $\lambda$ do motor C-9 na rotação de potência máxima 85

Tabela 27 - Valor $\lambda$ do motor E40 na rotação de potência máxima 85

Tabela 28 - Vazão em massa dos gases de escape do motor E25 86

Tabela 29 - Vazão em massa dos gases de escape do motor C-9 86

Tabela 30 - Vazão em massa dos gases de escape do motor E40 86

Tabela 31 - Vazão em massa dos gases $\mathrm{HC}, \mathrm{CO}$ e $\mathrm{CO}_{2}$ do motor $\mathrm{E} 25$ a $8.500 \mathrm{rpm}$

Tabela 32 - Vazão em massa dos gases $\mathrm{HC}, \mathrm{CO}$ e $\mathrm{CO}_{2}$ do motor C-9 a $8.500 \mathrm{rpm}$

Tabela 33 - Vazão em massa dos gases $\mathrm{HC}, \mathrm{CO}$ e $\mathrm{CO}_{2}$ do motor E40 a $8.500 \mathrm{rpm}$

Tabela 34 - Emissão dos gases $\mathrm{HC}, \mathrm{CO}$ e $\mathrm{CO}_{2}$ em g/km do motor E25 …........... 88

Tabela 35 - Emissão dos gases $\mathrm{HC}, \mathrm{CO}$ e $\mathrm{CO}_{2}$ em g/km do motor $\mathrm{C}-9$.............. 88

Tabela 36 - Emissão dos gases $\mathrm{HC}, \mathrm{CO}$ e $\mathrm{CO}_{2}$ em g/km do motor $\mathrm{E} 40$............... 88

Tabela 37 - Rendimento global do motor E25 ….................................................. 89

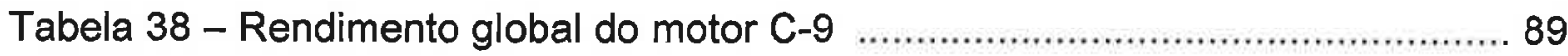

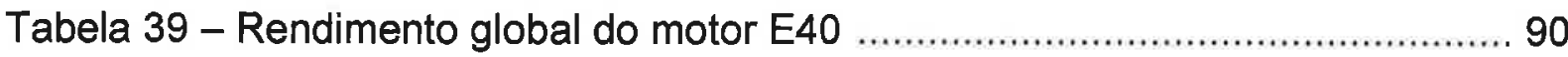

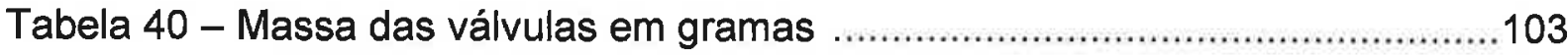

Tabela 41 - Massa das bóias do carburador em gramas ....................................103

Tabela 42 - Massa dos elastômeros do carburador em gramas após os testes de

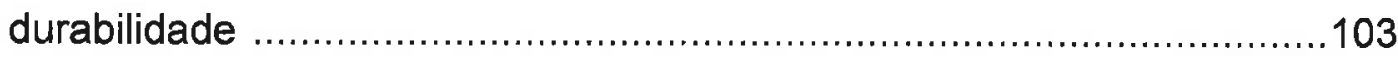

Tabela 43 - Valor inicial do diâmetro interno do cilindro (mm) ...............................104

Tabela 44 - Valor final do diâmetro interno do cilindro $(\mathrm{mm})$...................................104

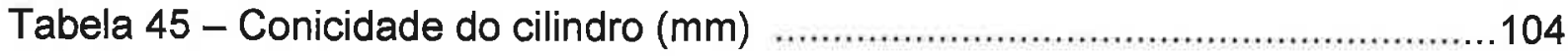

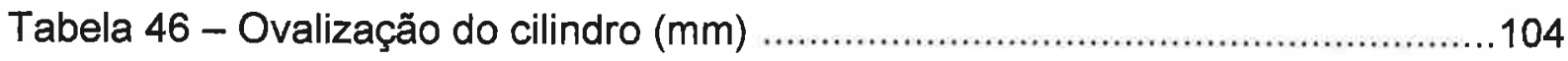

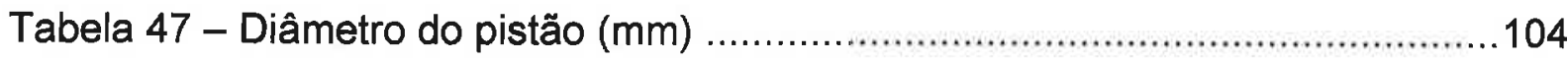

Tabela 48 - Folga entre cilindro e pistão (mm) ....................................................105

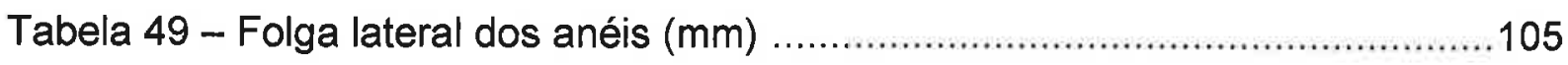

Tabela 50 - Valor inicial da folga entre pontas dos anéis $(\mathrm{mm})$...........................105

Tabela 51 - Valor final da folga entre pontas dos anéis $(\mathrm{mm})$..............................105

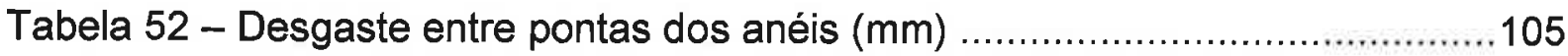

Tabela 53 - Desgaste da bomba de óleo trocoidal $(\mathrm{mm})$...................................106

Tabela B1 - Comprimento livre da mola $(\mathrm{mm})$................................................. 


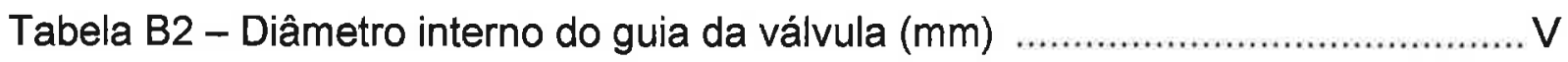

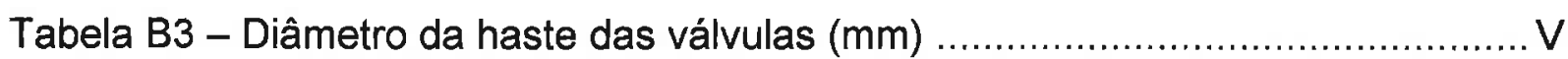

Tabela B4 - Folga entre a haste da válvula com o diâmetro interno do guia da válvula

$(\mathrm{mm})$

Tabela B5 - Came do eixo comando - parte com o ressalto $(\mathrm{mm})$........................ VI

Tabela B6 - Came do eixo comando - parte sem o ressalto $(\mathrm{mm})$......................... VI

Tabela B7 - Diâmetro interno do balancim $(\mathrm{mm})$............................................. VI

Tabela B8 - Diâmetro externo do pino do balancim $(\mathrm{mm})$..................................... VI

Tabela B9 - Folga entre o pino e o balancim $(\mathrm{mm})$.......................................... Vl

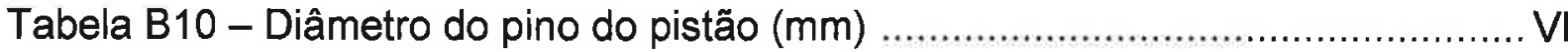

Tabela B11 - Diâmetro interno do alojamento do pino do pistão $(\mathrm{mm})$..................... VI

Tabela B12 - Folga entre o pistão e o pino do pistão $(\mathrm{mm})$................................... VII

Tabela B13 - Alinhamento do virabrequim $(\mathrm{mm})$............................................. VII

Tabela B14 - Folga lateral da biela com o virabrequim $(\mathrm{mm})$............................... VII

Tabela B15 - Largura do virabrequim (mm) ................................................. VII

Tabela C1 - Amaciamento do motor 1 utilizando o combustível E25 .................... VIII

Tabela C2 - Amaciamento do motor 2 utilizando o combustível E25 .......................IX

Tabela C3 - Amaciamento do motor 3 utilizando o combustível E25 .......................X

Tabela C4 - Durabilidade do motor 1 utilizando o combustível E25 ( $1^{\circ}$ ciclo) .......... XI

Tabela C5 - Durabilidade do motor 1 utilizando o combustível E25 ( $2^{\circ}$ ciclo) ......... XII

Tabela C6 - Durabilidade do motor 1 utilizando o combustível E25 ( $\left.3^{\circ} \mathrm{ciclo}\right)$........ XIII

Tabela C7 - Durabilidade do motor 2 utilizando o combustível C-9 ( $1^{\circ}$ ciclo) ........XIV

Tabela C8 - Durabilidade do motor 2 utilizando o combustível C-9 $\left(2^{\circ}\right.$ ciclo) .........XV

Tabela C9 - Durabilidade do motor 2 utilizando o combustível C-9 $\left(3^{\circ}\right.$ ciclo) ........XVI

Tabela C10 - Durabilidade do motor 3 utilizando o combustível E40 $\left(1^{\circ} \mathrm{ciclo}\right) \ldots . . . \mathrm{XVII}$

Tabela C11 - Durabilidade do motor 3 utilizando o combustível E40 ( $2^{\circ}$ ciclo $)$....XVIII

Tabela C12 - Durabilidade do motor 3 utilizando o combustível E40 $\left(3^{\circ} \mathrm{ciclo}\right)$......XIX

Tabela D1 - Concentrações de CO dos motores 1, 2 e 3 utilizando o combustível E25 na primeira medição após 0 amaciamento ..........................................XX

Tabela D2 - Concentrações de $\mathrm{CO}_{2}$ dos motores 1, 2 e 3 utilizando o combustível E25 na primeira medição após o amaciamento ...........................................XXI

Tabela D3 - Concentrações de HC dos motores 1, 2 e 3 utilizando o combustível E25 na primeira medição após o amaciamento XXII 
Tabela D4 - Potência do motor 1 utilizando o combustível E25 ao longo da durabilidade XXIII

Tabela D5 - Potência do motor 2 utilizando o combustível C-9 ao longo da durabilidade XXIV

Tabela D6 - Potência do motor 3 utilizando o combustível E40 ao longo da durabilidade XXV

Tabela D7 - Torque do motor 1 utilizando o combustível E25 ao longo da durabilidade XXVI

Tabela D8 - Torque do motor 2 utilizando o combustível C-9 ao longo da durabilidade XXVII

Tabela D9 - Torque do motor 3 utilizando o combustível E40 ao longo da durabilidade XXVIII

Tabela D10 - Consumo específico de combustível do motor 1 utilizando o combustível E25 ao longo da durabilidade XXIX

Tabela D11 - Consumo específico de combustível do motor 2 utilizando o combustível

C-9 ao longo da durabilidade $\mathrm{XXX}$

Tabela D12 - Consumo específico de combustível do motor 3 utilizando o combustível E40 ao longo da durabilidade $X X X I$

Tabela D13 - Concentrações de CO do motor 1 utilizando o combustível E25 ao longo da durabilidade XXXII

Tabela D14 - Concentrações de CO do motor 2 utilizando o combustível C-9 ao longo da durabilidade XXXIII

Tabela D15 - Concentrações de CO do motor 3 utilizando o combustível E40 ao longo da durabilidade XXXIV

Tabela D16 - Concentrações de $\mathrm{CO}_{2}$ do motor 1 utilizando o combustível E25 ao longo da durabilidade $X X X V$

Tabela D17 - Concentrações de $\mathrm{CO}_{2}$ do motor 2 utilizando o combustível C-9 ao longo da durabilidade $X X X V I$

Tabela D18 - Concentrações de $\mathrm{CO}_{2}$ do motor 3 utilizando o combustível E40 ao longo da durabilidade XXXVII

Tabela D19 - Concentrações de HC do motor 1 utilizando o combustível E25 ao longo da durabilidade XXXVIII

Tabela D20 - Concentrações de HC do motor 2 utilizando o combustível C-9 ao longo da durabilidade XXXIX 
Tabela D21 - Concentrações de HC do motor 3 utilizando o combustível E40 ao longo

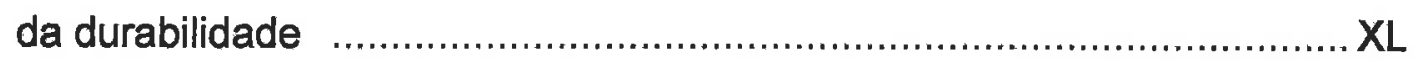

Tabela A1 - Análise do óleo lubrificante após o amaciamento ................................ XI

Tabela A2 - Análise do óleo lubrificante após o primeiro ciclo .............................. XLII

Tabela A3 - Análise do óleo lubrificante após o segundo ciclo ............................ XLIII

Tabela A4 - Análise do óleo lubrificante após o terceiro ciclo .............................XLIV 


\section{LISTA DE ABREVIATURAS E SIGLAS}

AEA Associação de Engenharia Automotiva

AEAC Álcool Etílico Anidro Carburante

AEHC Álcool Etílico Hidratado Carburante

ANP Agência Nacional do Petróleo, Gás Natural e Biocombustíveis

API American Petroleum Institute

ASTM American Society for Testing and Materials

CC Centímetros Cúbicos

IAD Índice Antidetonante

IPT-SP Instituto de Pesquisa Tecnológica - São Paulo

JASO Japanese Automobile Standards Organization

MAPA Ministério da Agricultura, Pecuária e Abastecimento

MON Motor Octane Number

NDIR Non-Dispersive Infrared Detector

$\mathrm{PCl} \quad$ Poder Calorífico Inferior

PROMOT Programa de Controle da Poluição do Ar por Motociclos e Veículos Similares

RON Research Octane Number

RPM Rotações Por Minuto

SAE Society Automotive Engineering

SOHC Single Overhead Camshaft

TAN Número de Acidez Total

TBN Número de Basicidade Total

UNICA União da Agroindústria Canavieira de São Paulo 


\section{LISTA DE SÍMBOLOS}

$\checkmark \quad$ velocidade

p perímetro do pneu

I2 relação total de engrenamento para segunda marcha

13 relação total de engrenamento para terceira marcha

14 relação total de engrenamento para quarta marcha

I5 relação total de engrenamento para quinta marcha

$\mathrm{N}$ rotação do motor

D distância percorrida

$t$ intervalo de tempo

$\bar{X}$ média aritmética

n número de amostras

x valor medido

$\sigma$ desvio padrão

xi valor medido

$\mathrm{E}$ incerteza

to//2 valor obtido para a distribuição t de Student com grau de liberdade $(n-1)$ e grau de confiança de $95 \%$.

$\mu \quad$ intervalo de confiança

$\bar{\rho} \quad$ massa especifica

n' quantidade de água calculada no AEAC

X massa total do combustível

n" quantidade de água calculada no AEHC

$\lambda$ relação ar-combustível

FEST relação combustível-ar teórica

FoBs relação combustível-ar observada

$\dot{m}_{\text {esc }}$ vazão em massa total dos gases de escape

$\dot{\mathrm{m}}_{\mathrm{c}} \quad$ vazão em massa do combustível

$\dot{\mathrm{m}}_{\mathrm{ar}}$ vazão em massa do ar

$\eta$ rendimento global

$\mathrm{C}_{\mathrm{e}} \quad$ consumo específico de combustivel 


\section{SUMÁRIO}

1. INTRODUÇÃO ...............................................................................4

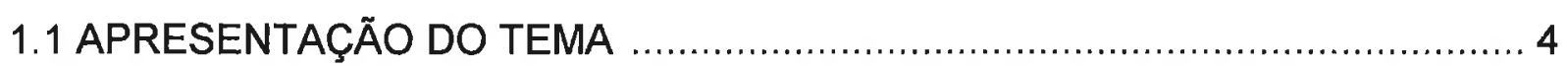

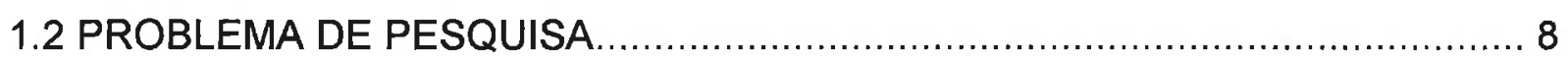

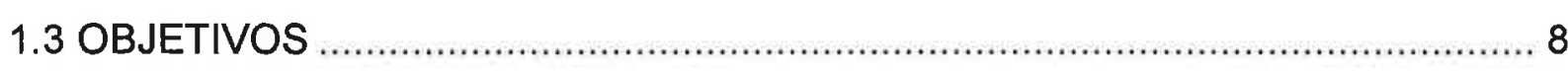

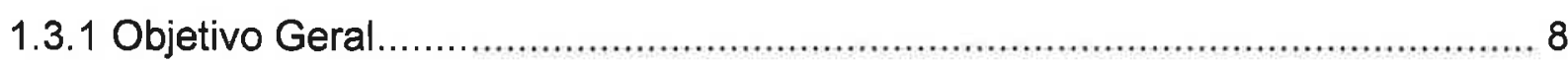

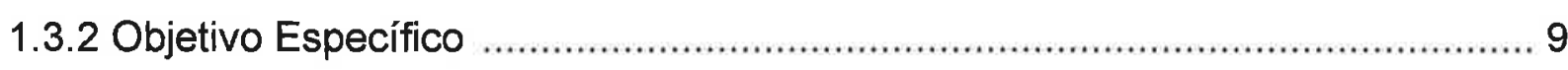

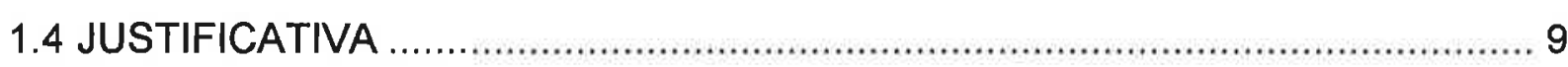

2. REVISÃO DE LITERATURA ......................................................10

2.1 EMISSÃO DOS GASES POLUENTES ……..................................................... 10

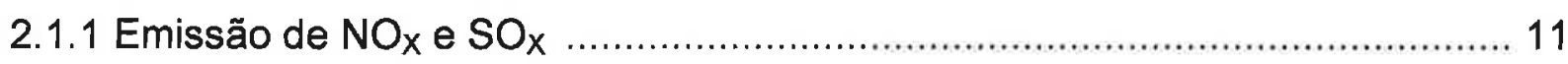

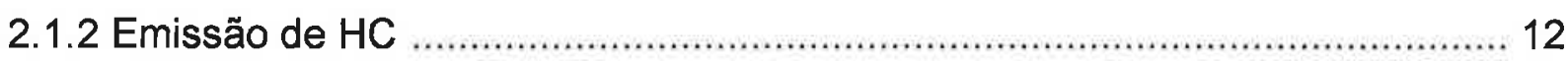

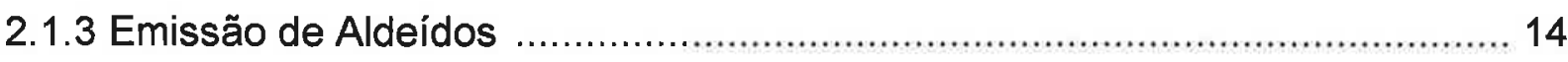

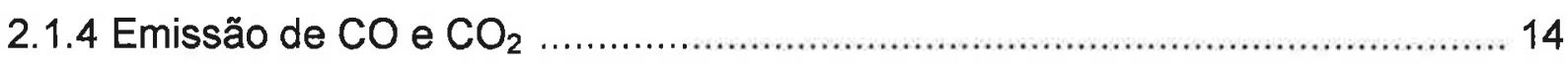

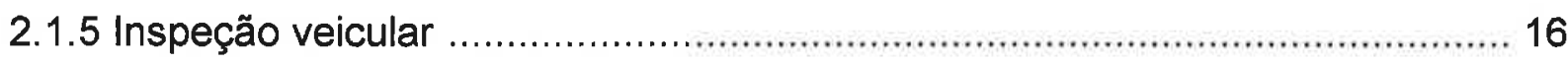

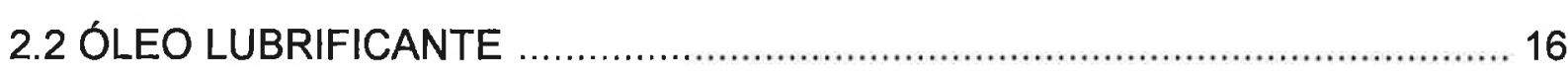

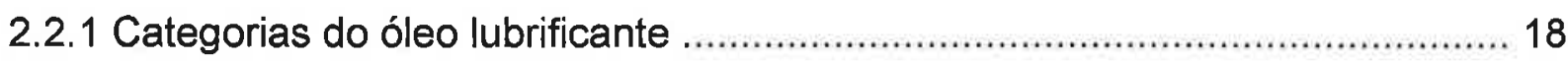

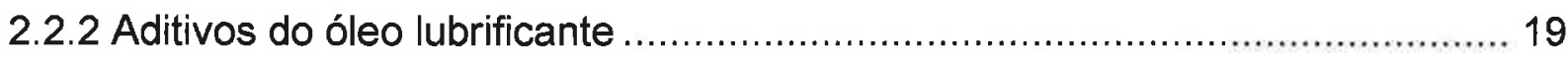

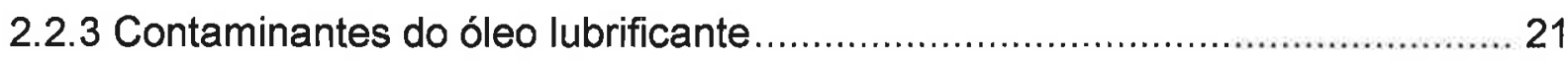

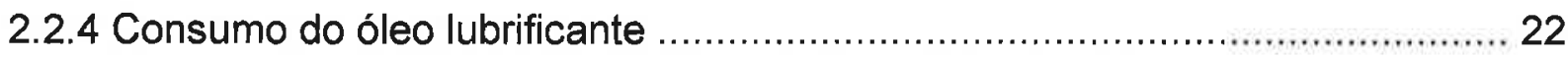

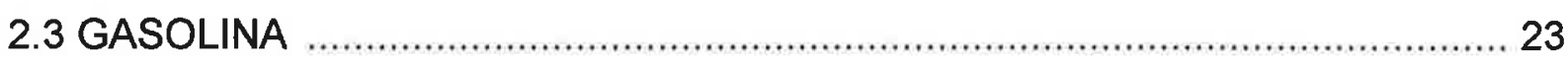

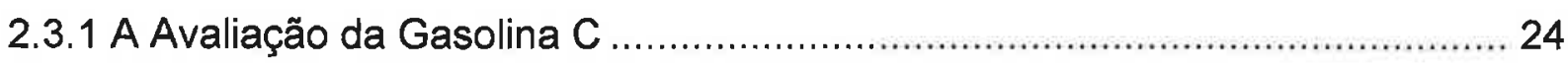

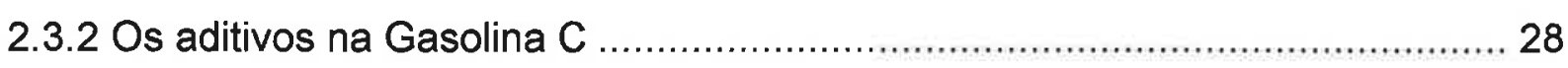

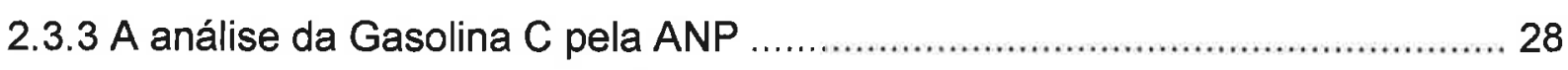

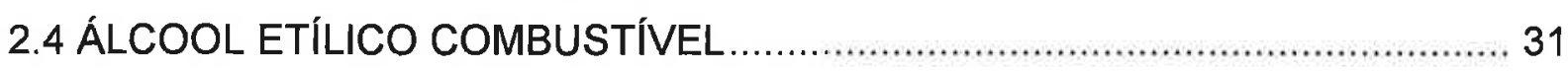

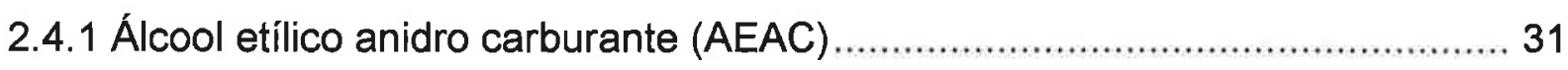

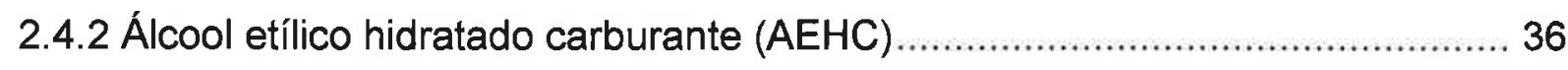

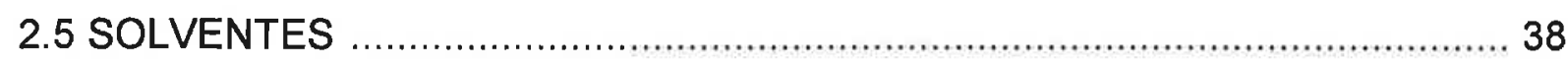

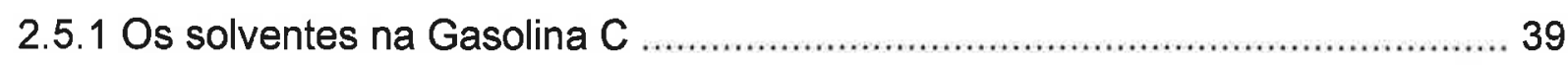

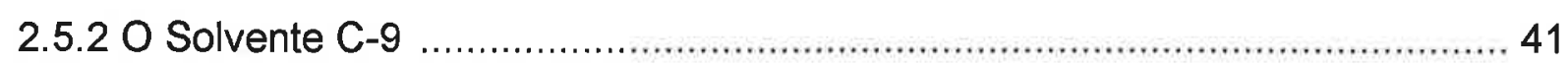


2.5.3 O marcador no solvente. 42

2.6.4 Aplicação dos solventes no mercado nacional. 42

3. DESCRIÇÃO DA METODOLOGIA 44

3.1 SELEÇÃO DOS MOTORES 44

3.2 PARÂMETROS DOS MOTORES DE 125cc UTILIZADO NO TRABALHO ....... 44

3.3 VERIFICAÇÕES NA MONTAGEM DOS MOTORES …................................... 49

3.4 DEFINIÇÃO DA MISTURA GASOLINA C COM AEHC ................................... 50

3.5 DEFINIÇÃO DA MISTURA GASOLINA C E O SOLVENTE C-9 ................... 51

3.6 PROCEDIMENTO PARA A MISTURA DOS COMBUSTÍVEIS ....................... 51

3.7 ENSAIOS NO DINAMÔMETRO DE BANCADA …...................................52

3.8 ACOMPANHAMENTO DO ÓLEO LUBRIFICANTE ….................................. 55

3.9 PROCEDIMENTO PARA A COLETA DO ÓLEO LUBRIFICANTE ................... 57

3.10 LEVANTAMENTO DA CURVA DE POTÊNCIA E TORQUE, CONSUMO E

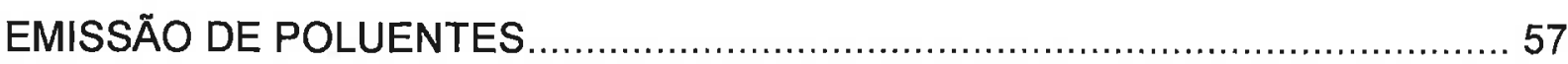

3.11 ANÁLISE ESTATÍSTICA USANDO A DISTRIBUIÇÃO T DE STUDENT ........ 58

3.12 EQUIPAMENTOS UTILIZADOS NA MEDIÇÃO DA CURVA DE POTÊNCIA E TORQUE, CONSUMO ESPECÍFICO E EMISSÃO DE GASES POLUENTES ........ 59

\section{RESULTADOS OBTIDOS E ANÁLISE} .61

4.1 ANÁLISE QUÍMICA DAS MISTURAS REALIZADAS ........................................ 61

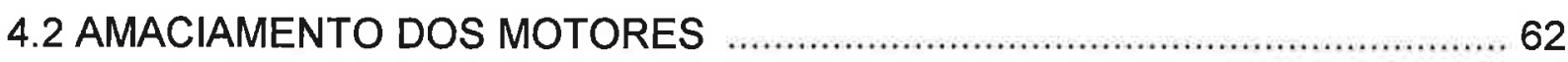

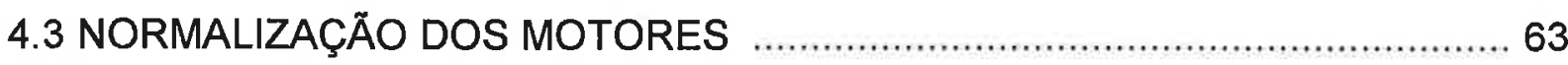

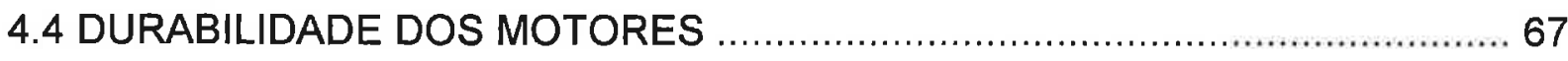

4.4.1 Análise do motor 1 abastecido com Casolina C (E25) ..................................... 67

4.4.2 Análise do motor 2 abastecido com gasolina adulterada (C-9) ........................ 69

4.4.3 Análise do motor 3 abastecidos com gasolina adulterada (E40) ................... 70

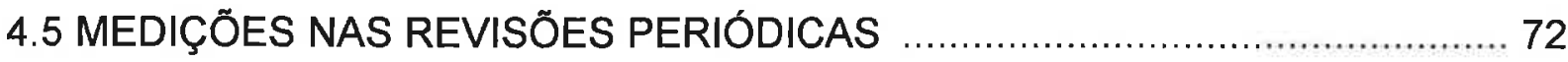

4.6 ANÁLISE DAS EMISSÕES DE POLUENTES …......................................... 74

4.6.1 Análise do motor 1 abastecido com Gasolina C (E25) ............................... 74

4.6.2 Análise do motor 2 abastecido com gasolina adulterada (C-9) ................... 76

4.6.3 Análise do motor 3 abastecido com gasolina adulterada (E40) ..................... 78

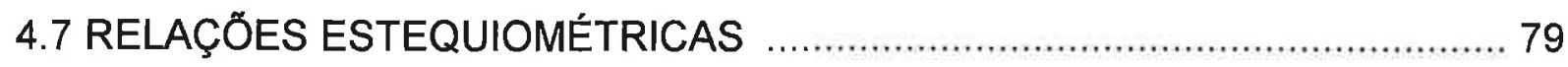

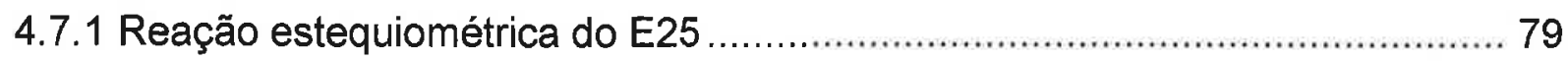




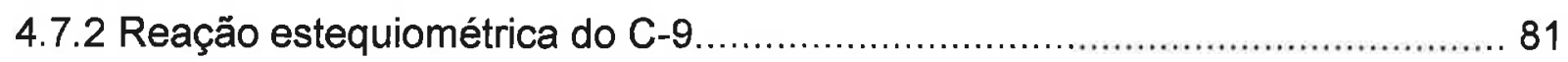

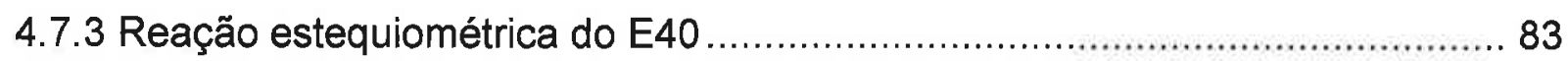

4.7.4 Emissões de poluentes na potência máxima .............................................. 85

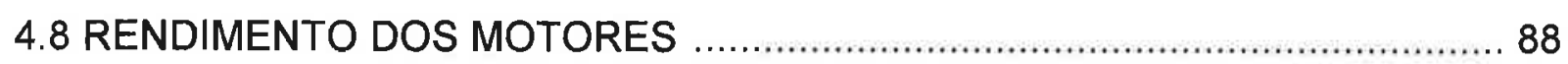

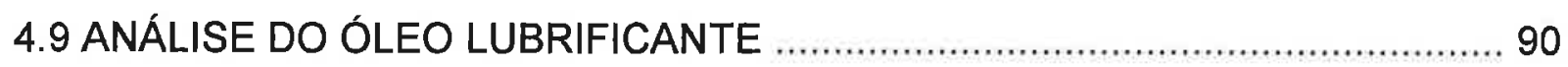

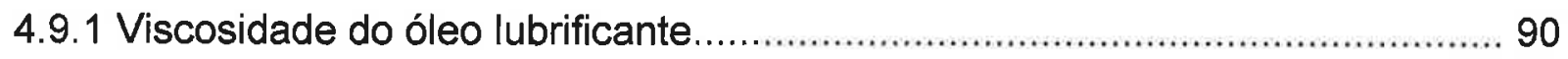

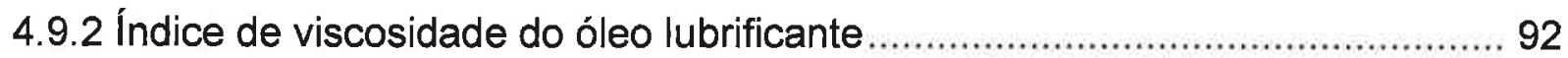

4.9.3 Número de basicidade e acidez total .......................................................... 93

4.9.4 Concentrações de metais nos óleos lubrificantes usados ............................ 94

4.9.5 Concentração de silício no óleo lubrificante usado .................................... 95

4.9.6 Oxidação, nitração e presença de sulfatos do óleo lubrificante ...................... 96

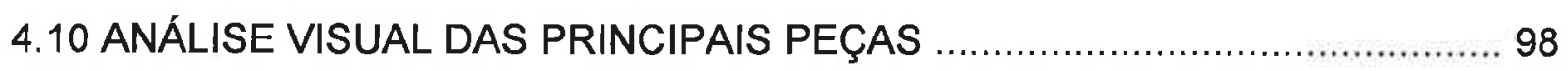

4.11 MEDIÇÕES FÍSICAS DOS MOTORES ............................................... 102

5. CONCLUSÕES ..............................................................................107

6. REFERÊNCIAS ........................................................................110

7. APÊNDICE

7.1 APÊNDICE A - Procedimento para a medição das principais peças ................... I

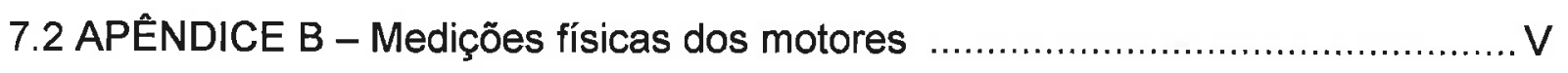

7.3 APÊNDICE C - Tabelas do amaciamento e da durabilidade dos motores ....... VIII 7.4 APÊNDICE D - Tabelas dos levantamentos das curvas de potência e torque, consumo específico e emissões $\mathrm{XX}$

8. ANEXO XLI

8.1 ANEXO A - Acompanhamento dos óleos lubrificantes analisados XLI 


\section{Introdução}

\subsection{Apresentação do Tema}

No Brasil, o refino do petróleo é fundamentalmente realizado pela Petrobras. Porém, a distribuição de combustíveis, ao longo dos últimos anos, sofreu mudanças significativas. Até o final da década de 1980, a distribuição de combustível vigorou em ambiente estritamente regulamentado, com postos de venda atrelados a contratos de concessão realizados junto a um pequeno número de distribuidoras. Entretanto, em 1993, o governo federal autorizou o funcionamento dos chamados postos de "bandeira branca" com o intuito de eliminar seu vínculo com a distribuidora, buscando criar melhores condições para o exercício da livre concorrência. Também nessa ocasião, houve mudanças nas regras para a criação de distribuidoras, o que permitiu que centenas de novas empresas entrassem no mercado de combustíveis.

Dessa forma, na segunda metade da década de 1990, a Agência Nacional do Petróleo, Gás Natural e Biocombustíveis (ANP), órgão setorial controlador da comercialização de combustíveis no Brasil, redefiniu as relações entre formuladores, distribuidoras, transportadoras e revendedores.

Entretanto, o que deveria alavancar a competição, facilitou a prática de adulteração de combustiveis. Dois fatores estimularam essa prática no mercado: o primeiro foi a carga tributária aplicada aos combustíveis que permitiu incidir $51,7 \%$ de impostos sobre os custos de alguns deles; a segunda foi a possibilidade de formulação do produto pelas distribuidoras. Com o objetivo de reduzir custos, alguns formuladores passaram a utilizar, alternativa e indevidamente, substâncias isentas ou com baixas tributações na sua formulação. As dificuldades de identificação, pelo consumidor e pelos órgãos de monitoramento e fiscalização, de desvios nas características físicoquímicas especificadas para o combustível facilitaram o uso dessas alternativas.

Em estudo realizado por Dutra (2004), a origem de ganhos ilícitos na comercialização de combustíveis é decorrente basicamente em dois pontos: o descaminho dos produtos e a adulteração da qualidade. No estudo proposto, levou-se em consideração o segundo ponto. A adulteração é a mistura de qualquer substância diferente ou acima das especificações permitidas, originadas por um produto de qualidade inferior. A adulteração pode ser devida tanto à adição de água, aguarrás e sucedâneos (como alguns tipos de solventes) à gasolina. Durante as fiscalizações, é 
constatado que as adições de álcool e solventes são as práticas mais comuns na adulteração da gasolina. Isso pode ser comprovado acessando os relatórios mensais divulgados pela ANP, onde são disponibilizadas informações sobre o uso de teor de álcool anidro ou hidratado acima do permitido e não conformidades nas curvas de destilação bem como índices de detonação abaixo dos valores mínimos da especificação.

Conforme Rolli (2005), as distribuidoras aprimoraram a mistura de solventes de tal forma que o produto adulterado se confunde com a gasolina. Porém, os sintomas acarretados com o consumo de combustíveis adulterados no motor são somente perceptíveis pelo consumidor depois de percorrer vários quilômetros. Além disso, os solventes são considerados commodities, cujo menor preço, via de regra, é o fator decisivo para ser utilizado na adulteração (ANP, 1999).

Ainda segundo Dutra (2004) da ANP, a adição de $30 \%$ de álcool etílico anidro carburante, contra os $25 \%$ especificados na maior parte de um ano, gera uma redução porcentual no preço final de 3,3\%; a adição de $30 \%$ de solvente à gasolina, gera uma redução percentual de $16,8 \%$ nesse mesmo preço final.

As margens de lucro em levantamento realizado no ano de 2003 , de acordo com a ANP, oscilam em torno de $5 \%$ a $15 \%$. A adição de $30 \%$ de álcool etílico anidro carburante aumenta consideravelmente essa margem de lucro, quer do revendedor, quer do distribuidor.

No que tange às empresas montadoras, os sintomas de mau funcionamento dos motores que utilizam combustíveis adulterados surgem ao longo da utilização e o descontentamento do consumidor acaba ficando, muitas vezes, associado a um menor desempenho e uma menor vida útil do veículo.

O consumo elevado de combustivel pode ser o primeiro sintoma e, conseqüentemente, a primeira reclamação do consumidor. O descontentamento com o produto pode aumentar, por exemplo, após um engripamento de válvulas do motor, decorrente de excesso de goma formado pelo uso de combustivel adulterado. Para um veículo ainda dentro do período de garantia, quem custeia soluções de problemas dessas naturezas é a conta de garantia do fabricante. Algumas reclamações são levadas para o Procon, Juizado de Pequenas Causas e Justiça Comum.

Entretanto, em geral, os reparos necessários são custeados pelo proprietário, que na maioria das vezes o utiliza na sua atividade profissional. A imagem da marca do fabricante e do veículo fica prejudicada e diminui a chance de uma recompra. 
No caso específico de fabricantes de motocicletas esses aspectos se agravam. O grau de instrução do público alvo e a renda mensal desses consumidores incentiva-os a procurarem postos de combustível com preços mais baixos. Segundo pesquisa apresentada por fabricante, ficou identificado que o público alvo de motocicletas de $125 \mathrm{cc}$ (centímetros cúbicos) de cilindrada total adquire o bem por financiamento e consórcio em prazos de sessenta meses em $90 \%$ dos casos. A faixa salarial desse consumidor está entre $R \$ 1.000,00$ (um mil reais) à $R \$ 2.000,00$ (dois mil reais).

Conforme Alvarez (2006), durante o Seminário promovido pela Associação de Engenharia Automotiva (AEA) em julho de 2006, estudos para aumentar a robustez das peças afetadas pelo combustível de má qualidade já vêm sendo realizados. $O$ objetivo é amenizar os efeitos causados por essa adulteração no funcionamento dos motores de quatro tempos.

Além disso, há dificuldades de se implementar um selo de qualidade para a gasolina devido ao grande volume comercializado desse combustível. Segundo Simionatto (2006), 30.000 litros de gasolina em um posto médio têm um consumo em torno de três a quatro dias, e no caso do uso de um selo, cada produto deve ser analisado. Só no estado de Santa Catarina há cerca de 1.500 postos, o que torna impossível a análise de toda a gasolina consumida.

O tema combustível adulterado nos manuais do proprietário dos fabricantes de veículos é tratado de forma a expor seus efeitos diretamente na durabilidade do motor, entretanto, alguns se omitem. Das quatro maiores montadoras no Brasil de veículos de quatro rodas, que representam mais de $70 \%$ nas vendas no mercado interno, somente a Volkswagen e a Ford incluem em seus manuais os problemas e os cuidados que os consumidores devem tomar no momento de abastecer o veículo. Por outro lado, a General Motors e a Fiat preferem não fazer comentários sobre combustíveis adulterados nos manuais analisados, informando apenas que o combustivel deve estar de acordo com as especificações.

Por exemplo, em folha avulsa dos manuais de proprietário dos veículos Ford inclue o seguinte texto:

Atenção! A utilização de combustível adulterado, contaminado ou de má qualidade, danifica componentes do motor. Reparos decorrentes desta condição não são cobertos em garantia. Para maiores informações consulte o 
capítulo combustível e lubrificante. (PUBLICAÇÃO FORD, 2006, p. avulsa)

Em seguida, no capítulo 12 do mesmo manual, são mencionados sintomas e efeitos do uso de combustível de qualidade inferior, adulterado ou contaminado, relacionados abaixo:

- Ruído anormal do motor;

- $\quad$ Falha do motor em aceleração;

- Perda de potência do motor;

- Vazamento de óleo pela caixa do filtro de ar;

- Consumo elevado de combustível;

- Consumo excessivo de óleo do motor;

- Emissão excessiva de fumaça pelo escapamento, dentre outros problemas.

De acordo com o manual de instruções, no capítulo abastecimento (PUBLICAÇÃO VOLKSWAGEN, 2006), um parágrafo em negrito deixa bem clara a responsabilidade que os consumidores têm em procurar um posto de combustível idôneo no momento do abastecimento. O parágrafo diz o seguinte:

Considerando-se que é praticamente impossivel a
fiscalização de todos os postos de combustivel,
recomendamos que o veículo seja abastecido em postos
das redes de distribuidores de combustível, que tenham
programas transparentes, para a certificação da qualidade
do produto ofertado. (PUBLICAÇÃO VOLKSWAGEN, 2006,
p.2-67)

Além disso, complementam dizendo que os concessionários já estão informados sobre problemas no motor decorrentes do uso de combustíveis adulterados.

Nos manuais do proprietário de motocicletas, as recomendações com relação ao combustível seguem as orientações dos veículos de quatro rodas. Os fabricantes Honda e Yamaha, que representam mais de $80 \%$ nas vendas de motocicletas no território brasileiro, incluem as recomendações e os cuidados no momento do abastecimento. 
No período de 14 de fevereiro a 04 de abril de 2007, no mesmo caderno semanal do Jornal do Carro (Jornal da Tarde, Seção Defenda-se) da cidade de São Paulo, constavam sete reclamações com imagens de consumidores e seus respectivos veículos dentro do período de vigência da garantia; as respostas dadas pelos fabricantes para problemas atribuíam como causas o uso de combustíveis adulterados. Dos sete casos apresentados, cinco são de fabricantes distintos e de diferentes segmentos de veículos, porém a insatisfação dos consumidores é a mesma.

Conforme Dias et al (2007), a lei Penal do artigo $1 .^{\circ}$, inciso I, da Lei n. ${ }^{\circ}$ 8.176/1991, que trata o crime de adulteração de combustíveis, na verdade, revela que a conduta de adulterar combustíveis não é criminalizada, mas sim, e exclusivamente, as condutas de adquirir, distribuir e revender.

O trabalho científico proposto estuda os efeitos das duas maneiras mais comuns de adulteração da gasolina em motores de pequena cilindrada. Para que o experimento venha a comprovar os danos causados ao motor pelo uso desses combustíveis adulterados, ao longo de seu planejamento e execução levou em conta o grau de confiabilidade e de reprodução do experimento, em seqüência padronizada em etapas, em conformidade com os princípios estabelecidos por Jung (2004).

\subsection{Problema de Pesquisa}

Como as gasolinas adulteradas com a adição de álcool etílico hidratado carburante $(A E H C)$ e/ ou solventes afetam o funcionamento dos motores de baixa cilindrada?

\subsection{Objetivos}

\subsubsection{Objetivo Geral}

Analisar como os combustiveis adulterados afetam o funcionamento de motores de ignição por faísca de baixa cilindrada, buscando identificar os componentes do motor mais prejudicados em função do consumo constante desse tipo de combustível, bem como afetam suas emissões. 


\subsubsection{Objetivos Específicos}

A análise segue os seguintes passos:

1-Identificar os adulterantes comumente utilizados na comercialização ilegal, sem a percepção imediata do consumidor, tomando como referência os relatórios emitidos pela ANP, conforme Boletim Mensal da Qualidade dos Combustíveis Automotivos Brasileiros e Conjuntura e Informação.

2 - Escolher duas adulterações mais importantes como objeto de estudo. Foram escolhidas duas misturas compostas por Gasolina $C$, uma com adição de solvente C-9 e outra com adição de AEHC em excesso.

3 - Definir ensaios comparativos de desempenho, emissões e durabilidade em três motores de $125 \mathrm{cc}$ (centímetros cúbicos), de mesma especificação técnica.

4 - Realizar ensaios comparativos de desempenho, emissões de poluentes e durabilidade.

\subsection{Justificativa}

O procedimento proposto tem grande potencial para fornecimento de informações relevantes sobre os efeitos do uso de combustíveis adulterados em motores de ignição por faísca de baixa cilindrada. 


\section{Revisão de Literatura}

2.1 Emissões dos gases poluentes

Os gases poluentes emitidos por motores de combustão interna de ignição por faísca podem ser gerados de duas maneiras: pela emissão de gases pelo escapamento ou pela evaporação de combustível.

Os principais gases poluentes decorrentes da combustão da gasolina são os óxidos de nitrogênio $\left(\mathrm{NO}_{\mathrm{X}}\right)$, hidrocarbonetos $(\mathrm{HC})$, monóxido de carbono (CO), óxidos de enxofre $\left(\mathrm{SO}_{\mathrm{X}}\right)$ e aldeídos.

A emissão dos poluentes está diretamente relacionada com a relação combustível-ar utilizada pelo motor. Dessa maneira, as emissões de $\mathrm{HC}, \mathrm{NO}_{x}$ e $\mathrm{CO}$ variam qualitativamente com a riqueza da mistura, num motor de ignição por faísca convencional (sem sistemas de pós-tratamento de gases) como mostra a Gráfico 1, a seguir.

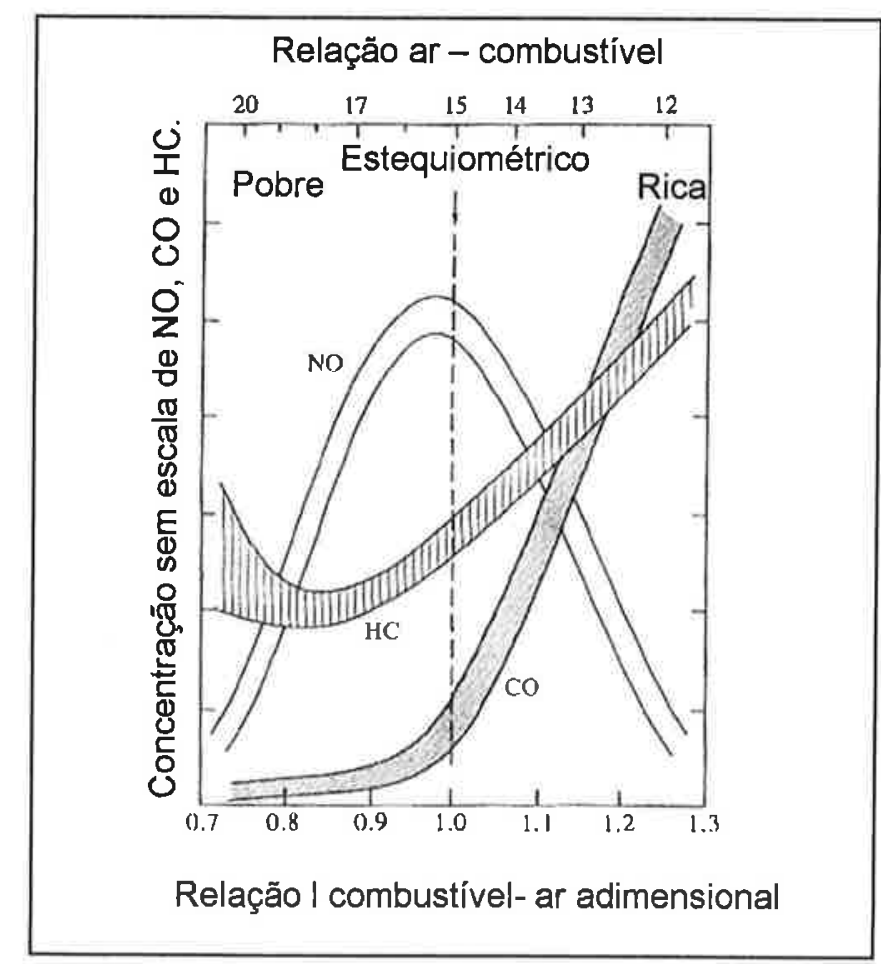

Gráfico 1: Concentração de HC, CO e NO no escape de um motor convencional de ignição por faísca, sem póstratamento, em funcionamento com gasolina em função da relaçăo ar-combustível (HEYWOOD, 1988). 


\subsubsection{Emissão de $\mathrm{NO}_{x}$ e $\mathrm{SO}_{x}$}

Óxidos de nitrogênio e enxofre são gerados por reações do nitrogênio (contido no ar ou combustível) e do enxofre (contido no combustível) com o oxigênio (do ar ou do combustivel) dentro da câmara de combustão. Os processos de reação e a formação na combustão estão profundamente interligados (HEYWOOD, 1988).

Temperaturas mais altas observadas durante a combustão aumentam a formação de óxido nítrico (NO) e dióxido de nitrogênio $\left(\mathrm{NO}_{2}\right)$, comumente agrupados como $\mathrm{NO}_{x}$, porém o $\mathrm{NO}$ é encontrado em maior proporção que $\mathrm{NO}_{2}$ nos escapamentos dos motores conforme o Gráfico 2.

A formação de $\mathrm{NO}_{2}$ pela reação do $\mathrm{NO}$ com $\mathrm{O}_{2}$, é de cerca de dois por cento da formação do NO para um motor por centelha a $1500 \mathrm{rpm}$ (rotações por minuto) e acelerador totalmente aberto (HEYWOOD, 1988), por exemplo.

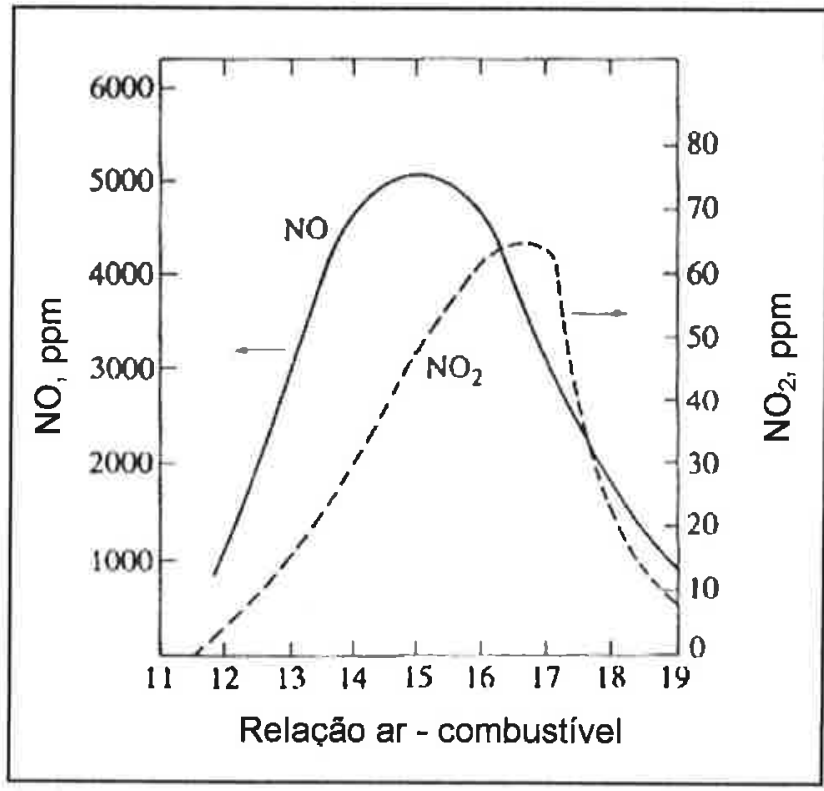

Gráfico 2: Concentrações de $\mathrm{NO}$ e $\mathrm{NO}_{2}$ no escapamento de um motor de ignição por centelha (HEYWOOD, 1988).

As produções de $\mathrm{NO}_{x}$ tendem a aumentar para os motores de ignição por centelha abastecidos com a mistura oxigenada de combustível. Por exemplo, a mistura E25 (25\% de etanol) aumenta a emissão de NOx na gasolina. No combustível E100, o valor de $\mathrm{NO}_{x}$ é ainda maior devido à ocorrência de maiores temperaturas na câmara de combustão e maior consumo de combustivel decorrente do menor poder calorífico do álcool etílico relativamente à gasolina. 
Outro fator que influi consideravelmente ao aumento de $\mathrm{NO}_{\mathrm{X}}$ é o instante de ignição. Na medida em que a ignição ocorre de forma mais antecipada no que diz respeito ao instante em que o pistão alcança o ponto morto superior (PMS) onde o volume do cilindro é menor, há maior razão de elevação de pressão observada no tempo de compressão. Conseqüentemente, observar-se-á maiores temperaturas instantâneas no cilindro com aumento na formação de NOx. (HEYWOOD, 1988).

A produção de $\mathrm{NO}_{2}$ é menor que $\mathrm{NO}$, porém é bastante mais prejudicial à saúde humana. $\mathrm{O} \mathrm{NO}_{2}$ afeta o sistema respiratório em exposição a curto e longo prazo, que inclui alteração na função pulmonar e aumento na predisposição de doenças respiratórias. Além disso, o $\mathrm{NO}_{2}$ é responsável pelo aumento do ozônio na atmosfera (POULTON, 1994) por ocasião de sua decomposição fotoquímica.

Diferente do nitrogênio presente na atmosfera na formação dos $\mathrm{NO}_{\mathrm{x}}$, a quantidade de $\mathrm{SO}_{\mathrm{X}}$ formada na reação de combustão está relacionada com a quantidade de enxofre presente na gasolina. A adição de etanol na composição da gasolina, reduz o teor de enxofre do combustível resultante.

$\mathrm{O}$ enxofre é oxidado produzindo $\mathrm{SO}_{2}$. Entretanto, algumas frações podem ser oxidadas em $\mathrm{SO}_{3}$, que combinado com a água, forma o ácido sulfúrico (HEYWOOD, 1988).

$\mathrm{Na}$ medida em que o teor de enxofre se reduz nos combustíveis, reduz-se, também, o potencial de produção de material particulado.

Combustiveis com alto teor de enxofre, principalmente o óleo diesel e a gasolina, são os principais causadores das chuvas ácidas nos grandes centros.

\subsubsection{Emissão de $H C$}

A emissão de hidrocarbonetos para o meio ambiente deve-se principalmente à combustão incompleta ou parcial do combustível, da evaporação no tanque de combustível, após desligar o motor e pelo efeito de blow by, momento em que parte dos gases queimados passa entre os anéis do pistão e cilindro e voltam para o filtro de ar para serem novamente queimados pelo motor e possivelmente para a atmosfera.

A presença de $\mathrm{HC}$ nos gases de escapamento deve-se fundamentalmente aos seguintes fenômenos observados num motor em funcionamento: após a combustão, parte do HC não queimado concentra-se em pequenas fissuras no cilindro no processo de expansão e exaustão; uma fina camada contendo a mistura ar- 
combustível queimada ou parcialmente queimada fica na parede do cilindro após o término da propagação da frente de chama.

O HC não queimado em camadas com espessuras menores que 0,1 milimetros podem ser posteriormente queimados rapidamente quando as paredes da câmara estão limpas; depósitos porosos no cilindro do motor aumentam a emissão de HC. Nesse caso trata-se da oxidação do $\mathrm{HC}$, que logo após o término da propagação da frente de chama, tem sua difusão promovida no cilindro (HEYWOOD, 1988).

O fino filme de óleo deixado na parede do cilindro, pistão e câmara de combustão pelo sistema de lubrificação aumenta a emissão do HC não queimado. Esse filme pode absorver ou soltar componentes dos hidrocarbonetos da gasolina, antes e depois da combustão.

Uma outra maneira de concentrar $\mathrm{HC}$ no escapamento deve-se à combustão incompleta que ocorre em condições de funcionamento do motor onde a combustão é especialmente lenta. Esse efeito ocorre em condições de funcionamento do motor em marcha-lenta ou quando ele está se acelerando ou se desacelerando (HEYWOOD, 1988).

Os hidrocarbonetos são formados por cadeias de carbono e hidrogênio de modo que a sua estrutura química, isto é, uma cadeia fechada ou aberta, influi diretamente na qualidade do combustível e conseqüentemente nas emissões e desempenho do motor (OWEN et al., 1990).

A composição do combustível pode influenciar significativamente a composição e a magnitude da emissão de orgânicos. Os combustíveis que contém altas proporções de aromáticos e olefinas produzem relativamente maior concentração de hidrocarbonetos reativos. Entretanto, muitos compostos orgânicos encontrados na exaustão não estão presentes no combustível, indicando que significativas reações de pirólise e de síntese ocorrem durante o processo de combustão (HEYWOOD, 1988).

Aproximadamente são encontrados 400 compostos orgânicos individuais na exaustão do veículo (POULTON, 1994; BALL et al, 1991; GRAEDEL et al, 1986). Desses compostos orgânicos, os voláteis altamente reativos (VOCs) têm um curto período de vida que contribuem substancialmente na reação fotoquímica atmosférica e conseqüentemente na formação de ozônio, peroxiacetis, nitratos e outros oxidantes. Os compostos orgânicos voláteis de longa vida são menos reativos e dispersos nas áreas urbanas e decompostos vagarosamente. Alguns compostos orgânicos voláteis são altamente tóxicos, sendo parte deles cancerígenos. 


\subsubsection{Emissão de Aldeídos}

Os aldeídos são formados pela combustão incompleta dos motores de combustão interna que utilizam a gasolina, o diesel, o metanol, o etanol, o propano, o metano como combustível ou combinações deles.

Os aldeídos presentes nos gases de escapamento em maiores quantidades são o acetaldeído e o formaldeído. O acetaldeído é o aldeído primário na exaustão dos gases de escape para o combustível etanol enquanto que o formaldeído é 0 aldeído primário para o metanol. $\mathrm{Na}$ atmosfera os aldeídos estão entre os mais reativos contribuintes para a formação de ozônio.

Tanto $\circ$ formaldeído quanto $\circ$ acetaldeído são tóxicos e possivelmente cancerígenos. Ambos são nomeados no 1990 US Clean Air Act Amendments (CAAA) como poluentes do ar tóxicos a serem controlados (POULTON, 1994).

$\mathrm{O}$ acetaldeído encontrado na queima do etanol é um veneno se ingerido e irritante se inalado ou em contato com a pele; o formaldeído é caracterizado como um veneno tanto por meio de ingestão quanto por inalação e contato com a pele. Dessa maneira, o formaldeído é mais nocivo que o acetaldeído e, conseqüentemente, o metanol em relação ao etanol, apesar da queima do etanol também produzir formaldeído.

No Brasil não há restrição na emissão de aldeídos na homologação de veículos e controle da frota para os abastecidos com o combustível conhecido como gasolina C ( $25 \%$ de álcool etílico anidro carburante - AEAC). Os controles são os mesmos encontrados na Comunidade Européia e Estados Unidos, porém o mercado brasileiro é o maior consumidor mundial de etanol em veículos que utilizam esse combustivel misturado à gasolina, e na comercialização de álcool etílico hidratado carburante (AEHC).

A redução na emissão dos aldeídos pode ser feita com a utilização dos catalisadores de três vias com o controle closed-loop e recirculação dos gases de escape (EGR - Exhaust Gas Recirculation).

\subsubsection{Emissão de $\mathrm{CO}_{\text {e } \mathrm{CO}_{2}}$}

A emissão do monóxido de carbono $(\mathrm{CO})$ também está associada à relação de equivalência da mistura ar-combustível nos motores de combustão interna. Se a 
mistura for rica, isto é, se a proporção em massa de combustível misturada ao ar é maior que aquela que gera uma combustão estequiométrica, a concentração de CO aumenta nos gases de escape; se a mistura for pobre, a concentração de CO se reduz. O Gráfico 3 apresenta a variação da emissão de CO com onze combustíveis em diferentes relações de ar - combustível.

O CO é um gás incolor, inodoro, insípido e levemente mais denso que o ar. Quando inalado pode entrar na corrente sanguínea e competir com o fornecimento de $\mathrm{O}_{2}$ pelo sistema pulmonar. Dessa maneira, afeta diretamente a saúde humana na troca de $\mathrm{O}_{2}$ com a hemoglobina, resultando na formação de carboxihemoglobina ( $\mathrm{COHb}$ ). Conseqüentemente, reduz a capacidade respiratória podendo levar à morte. A exposição ao monóxido de carbono aumenta os riscos de doenças cardiovasculares e a redução da capacidade para exercícios físicos, contribuindo para o ataque cardíaco (POULTON, 1994).

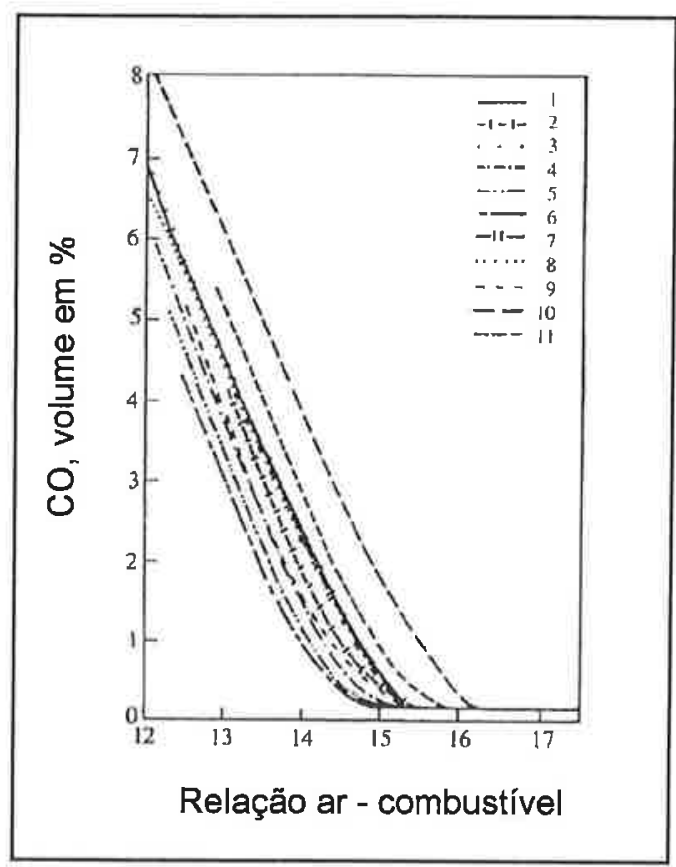

Gráfico 3: Variação da emissão de $\mathrm{CO}$ com onze combustíveis em diferentes relações de ar - combustível (HEYWOOD, 1988).

O monóxido de carbono é um produto intermediário no qual todo carbono deve passar quando oxidado. São oxidados na presença de $\mathrm{O}_{2}$ para a formação de $\mathrm{CO}_{2}$, porém esta oxidação não ocorre de forma adequada nos motores de combustão interna, principalmente nas condições de marcha lenta e desacelerações. Na atmosfera o CO pode ser oxidado em contato com o radical hidroxila $(\mathrm{OH})$, atuando indiretamente como gás do efeito estufa (POULTON, 1994). 
Segundo a World Health Organization, recomenda-se que os níveis de exposição ao $\mathrm{CO}$ não superem 85 ppm para um período de permanência máxima de quinze minutos, $50 \mathrm{ppm}$ para trinta minutos, $25 \mathrm{ppm}$ para uma hora e $10 \mathrm{ppm}$ para oito horas.

O dióxido de carbono $\left(\mathrm{CO}_{2}\right)$ é o maior produto na combustão dos motores e não afeta significativamente a formação de ozônio além de não ser tóxico. Porém entre os gases responsáveis pelo efeito estufa, $\circ \mathrm{CO}_{2}$ contribui em 50 por cento no efeito de aquecimento (POULTON, 1994).

\subsubsection{Inspeção veicular}

A Prefeitura do Município de São Paulo (PMSP) criou em 14 de abril de 1994, através do Decreto 34.009, o Programa de Inspeção e Manutenção de Veículos em Uso no Município de São Paulo (1/M-SP).

O programa I/M - SP foi regulamentado com o sancionamento e publicação da Lei $n^{\circ} 11.733$ de 1995, instituindo normas sobre a concessão do serviço de inspeção e funcionamento do programa I/M-SP. A Prefeitura realizou alterações no I/M, através da lei $n^{0} 12.157$ e regulamentou a lei $n^{0} 11.733$ com o decreto $n^{\circ} 36.305$; em 2008 , esses dispositivos foram alterados pela lei municipal 14.717 e decreto número 49.463.

Nos testes do I/M serão inspecionados os níveis de emissão de monóxido de carbono $(\mathrm{CO})$, de hidrocarbonetos $(\mathrm{HC})$, diluição (percentual de $\mathrm{CO}$ e $\mathrm{CO}_{2}$ ) e velocidade angular do motor (rotação em marcha lenta). Os limites são variáveis em função do ano de fabricação do veículo, devido à tecnologia utilizada.

O objetivo desse programa é forçar os usuários do transporte motorizado a manter os seus veículos bem regulados, não modificar ou introduzir modificações, e assim deter os impactos sob a qualidade do ar (STEINBAUM, 2008).

\section{2 Óleo lubrificante}

O óleo lubrificante no motor de $125 \mathrm{cc}$, de refrigeração a ar e cárter úmido, tem basicamente as mesmas propriedades e aditivos para lubrificar um motor de quatro tempos de automóveis. Porém, ao contrário dos veículos de quatro rodas, a maioria dos motores de motocicletas utiliza o mesmo óleo para lubrificar o motor, a embreagem 
e a transmissão. Nesses casos, alguns aditivos redutores de atrito podem impedir o funcionamento correto da embreagem.

A resistência ao escoamento do óleo ou de qualquer outro tipo de líquido é conhecida como viscosidade. Dessa maneira, lubrificantes de baixa viscosidade escorrem mais rápidos devido ao atrito interno deste oferecer menor resistência que o de um lubrificante considerado de elevada viscosidade. A viscosidade é uma das propriedades mais importantes do óleo lubrificante, pois é responsável diretamente na formação da película lubrificante e na manutenção do funcionamento adequado do motor ao longo de sua vida útil. Para isso, é necessário seguir as recomendações do fabricante quanto ao período de troca do óleo.

A medição da viscosidade é geralmente baseada no período de tempo em que o óleo, a uma temperatura preestabelecida, escorre por um orifício. Entre os mais comuns estão os viscosímetros Saybolt, o cinemático, o Redwood e o Engler. Outra avaliação seria pela classificação SAE (Society Automotive Engineering - Sociedade dos Engenheiros Automotivos).

$O$ índice de viscosidade tem a função de definir a variação da viscosidade do óleo com a temperatura, isto é, quanto mais elevado for o índice de viscosidade, menor será a variação da viscosidade com a temperatura, quando comparado com outro óleo de menor índice de viscosidade.

A eficiência do óleo lubrificante deve levar em conta a velocidade com que deve fluir, a carga entre as superfícies que deve suportar e a temperatura de trabalho que deve manter, garantindo as propriedades suficientes para o correto funcionamento do motor. Esses três fatores determinam à viscosidade adequada de acordo com o tipo de utilização.

Além disso, o número de basicidade total (TBN) e de acidez total (TAN) são avaliados pelo número equivalente em miligramas de hidróxido de potássio por gramas ( $\mathrm{mg} . \mathrm{KOH} / \mathrm{g}$ ), quanto maior o número, mais básico e quanto menor o número, mais ácido será a solução avaliada.

A oxidação, nitração e a presença de sulfatos são medidas em absorbância por centímetro $(\mathrm{Abs} / \mathrm{cm})$ e tendem a aumentar seus valores de acordo com a vida útil do óleo lubrificante em funcionamento no motor e no combustível utilizado. 
2.2.1 Categorias do óleo lubrificante

Há três categorias básicas do óleo lubrificante, a primeira é estabelecida pela SAE (Society of Automotive Engineers), que padroniza a viscosidade, a segunda quanto à aplicação do óleo pelo API (American Petroleum Institute) ou pela JASO (Japanese Automobile Standards Organization) e, por último a base de fabricação do óleo.

A categoria SAE estabelece determinados limites em unidades de tempo (segundos) para determinar a viscosidade. No caso de lubrificantes para motores de combustão interna, há, por exemplo, os índices $5 \mathrm{~W}, 10 \mathrm{~W}, 20 \mathrm{~W}, 30,40$ e 50 , ou multiviscosos, que tem pouca mudança de viscosidade em relação à temperatura. Como por exemplo, o 10W30, 20W40 e 20W50, conforme apresentado no Gráfico 4.

A categoria API ou JASO, refere-se ao rendimento ou aplicação do óleo lubrificante. Como por exemplo, a classificação pode ser SE, SF, SG, SH, SJ e SL entre outras. Quanto maior a segunda letra do alfabeto, maior concentração e tipos de aditivos apresentará o óleo lubrificante.

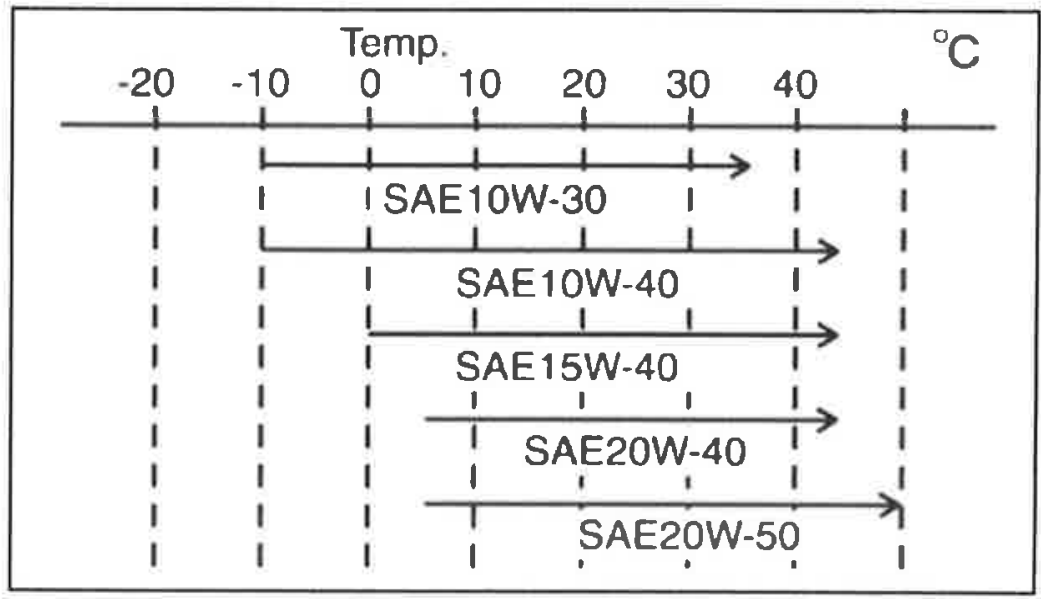

Gráfico 4: Classificação SAE dos óleos multi-viscosos em função da temperatura (PUBLICAÇÃO YAMAHA, 2007).

A categoria como material base do óleo lubrificante pode ser mineral, vegetal, sintético e semi-sintético. O mineral é o óleo base usual nas motocicletas de baixa cilindrada, comumente nos modelos de $125 \mathrm{cc}$.

O óleo vegetal tem uma excelente lubrificação comparado ao mineral, porém a oxidação ocorre mais rápida em contato com o ar e são utilizados, em geral, somente em motores de competição (PUBLICAÇÃO YAMAHA, 2000). 
Os óleos sintéticos são elaborados para manter uma viscosidade estável em altas e baixas temperaturas e têm características que superam as especificações dos óleos minerais, podendo ser utilizados por períodos de tempo maiores. Por último temse o semi-sintético, que é composto por uma mistura de óleo mineral com o sintético, e apresentam características de estabilidade no óleo com propriedades de um mineral.

\subsubsection{Aditivos do óleo lubrificante}

Os aditivos em sua maioria são aditivos formados por materiais solúveis em óleo, preparados usando o próprio óleo como solvente. Devido à estabilidade no armazenamento e na facilidade de manipulação, os aditivos chegam a representar de 30 a $75 \%$ em massa no óleo (BENFAREMO, 1991).

Os pacotes de aditivos podem apresentar algumas variações de acordo com a aplicação, sendo que, um pacote típico de aditivos pode ser composto como mostra o Gráfico 5 abaixo:

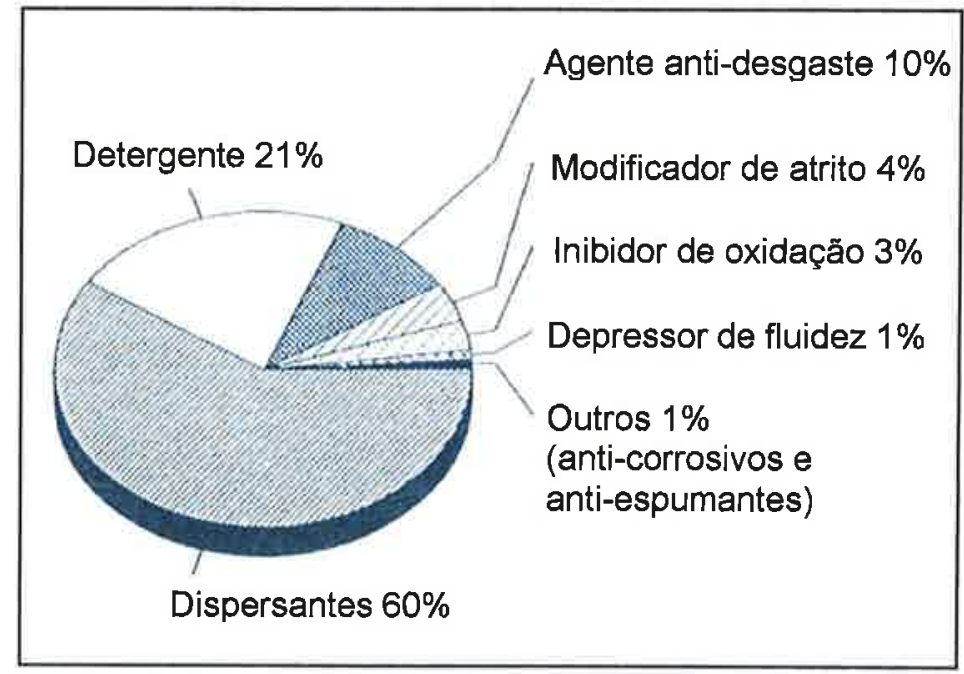

Gráfico 5: Pacote típico de aditivos (BENFAREMO, 1991).

Enquanto que os dispersantes são materiais que solubilizam ou inibem a formação de borra no motor em temperaturas baixas, o detergente são materiais que reduzem, impedem a formação ou até eliminam os depósitos em temperaturas elevadas (BENFAREMO, 1991).

Devido às exigências de controle de borras e da oxidação nos motores atuais e na necessidade de uma classificação de serviço API (como SL, por exemplo) há uma alta concentração de dispersantes no aditivo. 
Os detergentes, além de reduzir e eliminar depósitos, também oferecem proteção contra a oxidação. Os metais mais comuns utilizados são o sódio, o cálcio e o magnésio.

Os detergentes sobre-básicos são utilizados principalmente para neutralizar os ácidos produzidos pelo processo de combustão e pela oxidação do óleo. Os fenatos por exemplo, que são usados comercialmente como detergente, também conferem propriedades anti-oxidantes. Já os fosfanatos, também usados como detergentes, têm propriedades de carga, anti-desgaste e anti-oxidante.

Basicamente, a oxidação ocorre pela reação do lubrificante quente com o ar, nos resíduos do combustível e na presença de subprodutos da combustão. Dessa maneira, a oxidação no cárter do óleo lubrificante é muito complexa (BENFAREMO, 1991).

Para que o anti-oxidante exerça a função eficazmente, é necessário romper as etapas de propagação das cadeias das reações oxidantes. Por isso, a escolha do anti-oxidante está diretamente relacionado com as condições que o óleo lubrificante será submetido.

A maioria dos agentes anti-desgaste são de compostos que contém enxofre elou fósforo, de modo que uma película de polissulfeto protege as superfícies envolvidas. Compostos de enxofre-molibdênio também tem se mostrado eficazes aditivos anti-desgaste (BENFAREMO, 1991).

A Figura 1 abaixo apresenta, de forma esquemática, duas superfícies em movimento relativo sob condições de lubrificação inferiores às limites.

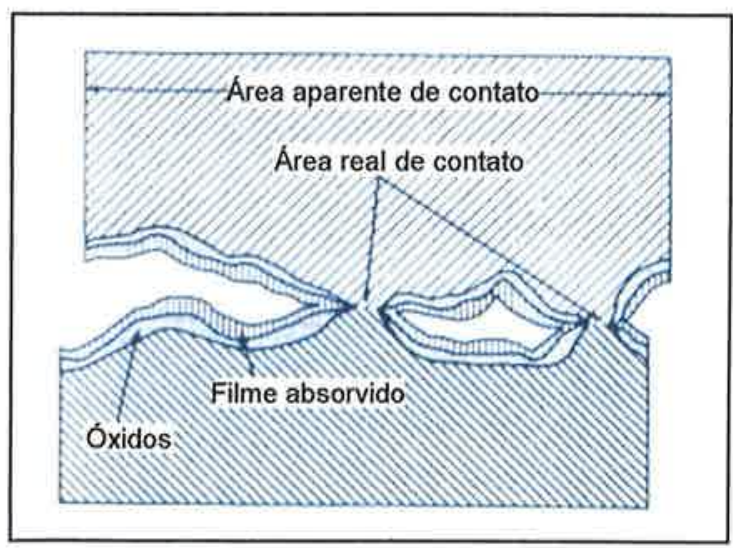

Figura 1: Superfícies em movimento relativo abaixo das condições limites de lubrificação (HEYWOOD, 1988). 
Os modificadores de atrito são relacionados aos aditivos de extrema pressão na estrutura e modo de ação na lubrificação do motor. Os aditivos a base de dissulfeto de molibdênio são eficientes modificadores de atrito.

Os depressores de ponto de fluidez apresentam maior vantagem em baixas temperaturas para o desempenho adequado em climas frios, que tem a função de reduzir o ponto de fluidez do óleo. A eficácia desse aditivo depende basicamente do peso molecular, da composição química e outras características estruturais da molécula do polímero (BENFAREMO, 1991).

Os inibidores de corrosão atuam nas superfícies metálicas de modo que a composição química desse aditivo adere nos metais criando um revestimento de proteção. Funcionam especificamente para evitar a corrosão de metais ferrosos impedindo que a água ou outro material corrosivo entre em contato com essa superfície.

A espuma no óleo do motor retém grandes quantidades de ar e água, e em temperaturas elevadas, há oxidação do óleo. Por isso os anti-espumantes são fundamentais para evitar a oxidação e a reduzir a pressão do óleo.

\subsubsection{Contaminantes do óleo lubrificante}

A periodicidade da troca da carga de óleo lubrificante é definida em função de sua deterioração decorrente, principalmente, da sua contaminação pelo combustível utilizado.

Além disso, o acúmulo de partículas sólidas, água e solventes afetam o comportamento dos lubrificantes.

Considerando que o circuito de óleo no motor de quatro tempos é fechado, a presença de impurezas são decorrentes principalmente de poeira em suspensão no ar e da falta de manutenção adequada no filtro de ar.

A água é produzida em grande parte após a parada do motor. Os efeitos no comportamento do lubrificante se apresentam sob a forma de emulsões, que em conjunto com as impurezas, formam resíduos e borras que dificultam a lubrificação.

A presença de outros fluídos diluídos, tais como solventes, altera as propriedades dos lubrificantes, principalmente a viscosidade e a estabilidade química. Conseqüentemente surgem problemas de superaquecimento, desgaste, corrosão e ferrugem. 


\subsubsection{Consumo do óleo lubrificante}

A maior parte do consumo de óleo lubrificante, nos padrões normais de funcionamento de um motor de quatro tempos, está entre o guia de válvulas e a haste da válvula (PUBLICAÇÃO YAMAHA, 2000). Após a lubrificação nesse ponto, o óleo flui para a câmara de combustão, local onde é queimado. Por isso, o retentor da haste da válvula deve ser dimensionado para manter um consumo mínimo de óleo,conforme apresenta a Figura 2 abaixo.

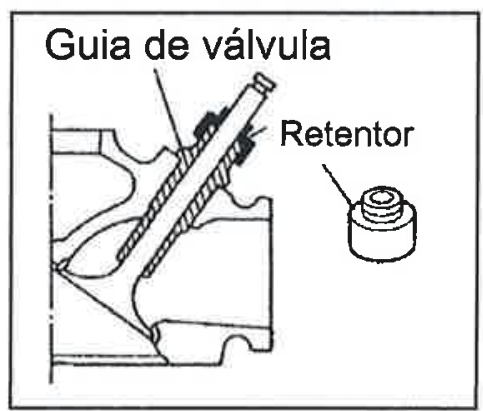

Figura 2: Guia da válvula, retentor e haste da válvula (PUBLICAÇÃO YAMAHA, 2000).

Outro ponto importante de consumo de óleo está entre o cilindro e o pistão, principalmente quando os anéis apresentam desgastes. As forças que atuam nesse contato hidrodinâmico são complexas e dependem do tempo e da mudança do deslizamento dos anéis, como apresentado na Figura 3.

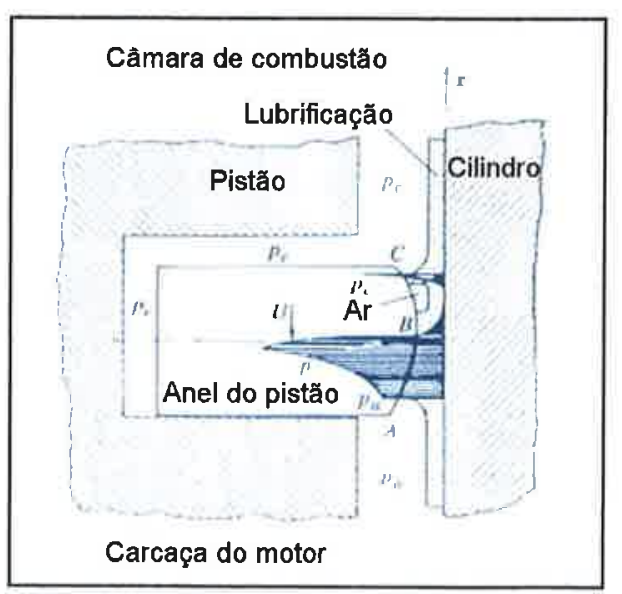

Figura 3: Distribuição de pressão no filme de óleo lubrificante no tempo de expansão, corte longitudinal (HEYWOOD, 1988).
$P C=$ pressão do cilindro;

Pir = pressão do anel interno;

$P=$ pressăo

$U=$ velocidade relativa entre as duas superfícies $A B C=$ superfície do anel 
A lubrificação da biela com o virabrequim está diretamente relacionada com a correta lubrificação dos anéis do pistão. Uma lubrificação deficiente provocará um desgaste excessivo dos anéis, e conseqüentemente, um consumo elevado do óleo lubrificante. A Figura 4 esquemática mostra a distribuição de pressão no filme de óleo lubrificante no virabrequim para uma dada condição de funcionamento do motor.

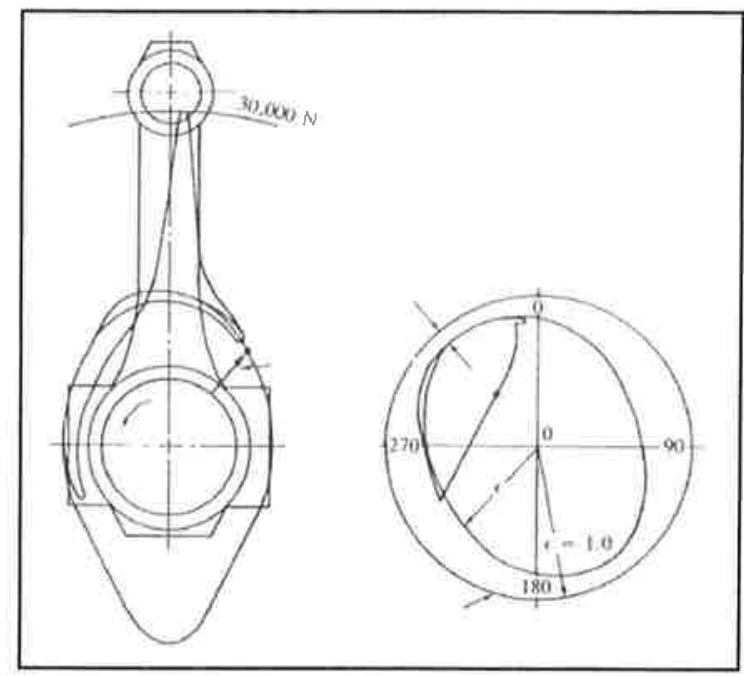

Figura 4: Distribuição de pressão no filme de óleo lubrificante no virabrequim (HEYWOOD, 1988).

Em suma, por melhor que seja o lubrificante, após um uso contínuo em temperaturas e cargas distintas, sua oxidação é inevitável, tornando-se mais viscoso e potencializando a formação de gomas e lacas que prejudicarão o sistema de lubrificação, e em muitos casos, a substituição de componentes do motor.

\subsection{Gasolina}

A "qualidade" da gasolina é essencial para o correto funcionamento do motor de combustão interna. Variações em sua composição química podem promover condições de mau funcionamento, utilização dificultada do veículo e a percepção de perda de desempenho pelo usuário.

Assim como o projeto dos motores vem se aperfeiçoando, a melhoria da qualidade dos combustiveis acompanha esta evolução, particularmente em termos de qualidade anti-detonante que reduz as ocorrências de anomalias de combustão (pré- 
ignição e detonação), que limitam a potência disponibilizada e pode trazer prejuízos catastróficos no motor (OWEN et al., 1990).

A gasolina automotiva brasileira tem sua especificação para a comercialização definida pela Portaria ANP n 309 de 27 de dezembro de 2001 por meio do Regulamento Técnico $n^{\circ} 5$ de 2001. É proibida, no Brasil, a comercialização de gasolina sem a adição de $A E A C$, ou seja, da denominada gasolina $A$. $A$ adição de AEAC na gasolina é definida pelo Ministério da Agricultura, Pecuária e Abastecimento (MAPA) pela Portaria MAPA n० 554 de 27 de maio de 2003.

A adição de $25 \%$ em volume de AEAC está em vigor atualmente conforme a Lei $n^{\circ} 8.723$, de 28 de outubro de 1993, a qual dispõe que o Poder Executivo fixe o percentual da mistura de álcool anidro na gasolina no intervalo de $20 \%$ a $25 \%$. Entretanto, a tolerância adotada é sempre de 1\%, considerando a forma que é preparada nas distribuidoras.

A composição da gasolina depende da origem do petróleo e dos processos que são utilizados no refino. Os hidrocarbonetos que formam a gasolina vão de 4 a 13 átomos de carbono, massa específica de 740 a $776 \mathrm{~kg} / \mathrm{m}^{3}$ e temperatura de ebulição de 30 a $225{ }^{\circ} \mathrm{C}$. Dessa maneira, a gasolina é formada por uma mistura de hidrocarbonetos líquidos voláteis e inflamáveis. Os hidrocarbonetos são subclassificados em parafínicos, olefínicos, naftênicos e aromáticos.

\subsubsection{A Avaliação da Gasolina C}

Os itens avaliados na especificação da Gasolina C estão na Tabela 1 e são discutidos a seguir.

A cor e 0 aspecto da gasolina são verificados visualmente, indica a presença de contaminantes ou oxidações de compostos instáveis que podem causar entupimento do sistema de combustível e perda de desempenho do veículo.

A mudança no teor de adição de AEAC altera o número de octano e a emissão de poluentes, porém, em geral, é imperceptível ao consumidor.

A massa específica permite identificar a adição de compostos mais leves ou pesados em uma possível adulteração na gasolina, porém não identifica em caso de adição de solventes e AEHC em quantidades controladas.

A destilação permite traçar uma curva em função das características da gasolina que tem uma mistura de muitos compostos, e conseqüentemente, diferentes 
pontos de ebulição. A curva de destilação é utilizada para a identificação de adulteração na gasolina, porém há casos de adição de solventes controlados que não são identificados.

O número de octano é obtido a partir da combustão de misturas de dois hidrocarbonetos parafínicos puros de estruturas químicas selecionados como padrões. O primeiro é o iso-octano (2,2,4 trimetilpentano ou iso-octano) que tem alta resistência à detonação e classificado com o valor 100; o outro é o n-heptano, com baixa resistência a detonação e classificado com o valor zero. O número de octanas do combustivel é o volume percentual do iso-octano em relação ao n-heptano que apresenta o mesmo desempenho em termos de detonação ao obtido num teste em motor e condições padronizadas (OWEN et al., 1990).

Dois parâmetros definem o índice antidetonante (IAD) de um combustível para motores de ignição por faísca: o número de octano pesquisa (RON - research octane number), que está correlacionado a condições de dirigibilidade suave, e o número de octano motor (MON- motor octane number), que está relacionado ao uso de motores em condições severas.

$\mathrm{Na}$ especificação da gasolina $\mathrm{C}$ é solicitado o número octano motor e o índice antidetonante. O IAD é a média aritmética dos resultados obtidos para o RON e - MON do combustível.

A adição de solvente na gasolina, dependendo do composto utilizado, pode aumentar ou reduzir o indice antidetonante enquanto que a adição de AEHC somente aumenta esse índice.

A pressão do vapor indica a maior pressão absoluta a qual uma substância pode ser submetida, numa determinada temperatura, mantendo-se na forma de vapor exclusivamente. Esse valor máximo é de $69 \mathrm{kPa}$ para a gasolina. Porém, para facilitar a partida a frio nos meses de menor temperatura de Estados como Rio Grande do Sul, Santa Catarina, Paraná, São Paulo, Rio de Janeiro, Espírito Santo, Minas Gerais, Mato Grosso, Mato Grosso do Sul, Goiás e Tocantins, bem como para o Distrito Federal, admite-se, nos meses de abril a novembro, um acréscimo de $7,0 \mathrm{kPa}$ ao valor máximo especificado para a pressão de vapor (ANP, 2001).

O volume de goma identifica a presença dos compostos olefínicos que são muito menos estáveis à oxidação do que os compostos aromáticos ou parafínicos. Altos teores de olefinas geram instabilidade química na gasolina devido à reação com outros hidrocarbonetos na presença de oxigênio, luz ou calor, promovendo a formação 
de goma. Os processos de craqueamento da gasolina podem dar origem a compostos di-olefínicos em adição de mono-olefínicos, tornando as gasolinas significativamente mais suscetíveis à oxidação e à formação de goma (OWEN et al., 1990).

O período de indução a $100^{\circ} \mathrm{C}$ é de no mínimo de 360 minutos. Este vapor pode ser correlacionado com o periodo de estocagem da gasolina.

A corrosividade ao cobre a $50^{\circ} \mathrm{C}$ tem a função de verificar o grau de corrosão que ocorre nas peças metálicas do motor após três horas em contato com essa gasolina.

O teor de enxofre não pode ultrapassar o valor de $0,10 \%$ em massa. $O$ enxofre é responsável pela formação de material particulado e gases poluentes como 0 $\mathrm{SO}_{2}$ e $\circ \mathrm{SO}_{3}$, que originam as chuvas ácidas, e além disso, sua ação corrosiva deteriora o óleo do motor e causa corrosão nas peças do motor em contato com os gases de escape tais como catalisadores.

O benzeno é um hidrocarboneto encontrado na gasolina no qual não pode passar o valor de $1 \%$ em volume na gasolina. Contatos repetidos com esta substância tornam a pele vermelha, seca e áspera e promovem rachaduras devido a sua ação solubilizante sobre a camada gordurosa da pele. Contínuas exposições podem resultar em anemia e leucemia. Essa agressão à medula óssea é a principal ação tóxica do benzeno numa exposição crônica (BRASKEM, 2005).

O chumbo é um metal de elevada toxicidade adicionado à gasolina com a finalidade de aumentar o seu índice anti-detonante. É um dos componentes mais bem controlados na especificação do combustível pois tem efeitos fortemente degenerativos sobre a saúde humana; nos veículos, reduz, por exemplo, a durabilidade dos catalisadores. No Brasil, a quantidade de chumbo na gasolina não pode exceder o valor de 0,005 g/l. Esse valor está associado à possibilidade de contaminação e não ao fato de serem permitidas adições desse metal durante a produção.

Uma última consideração diz respeito às porcentagens máximas em volume de hidrocarbonetos (valores porcentuais máximos em volume de $45 \%$ de aromáticos e $30 \%$ de olefínicos). A alta porcentagem de hidrocarbonetos aromáticos permitida na especificação da gasolina é explorada pelos adulteradores de gasolina que se utilizam de solventes com essa estrutura química, sem desrespeitar os limites da especificação regulamentada pela ANP. 
Tabela 1. Especificação da Gasolina Comum tipo C. Portaria ANP n 309 de 27/12/2001.

\begin{tabular}{|c|c|c|c|}
\hline Característica & Unidade & Especificação & Normas \\
\hline Cor & \multirow{2}{*}{ não tem } & \multirow{2}{*}{$\begin{array}{l}\text { De incolor a amare lada se isento de corantes, } \\
\text { Ilmpida e isento de impurezas. }\end{array}$} & \multirow{2}{*}{$\begin{array}{l}\text { NBR } 7148 \\
\text { ASTM D } 1298\end{array}$} \\
\hline Aspecto & & & \\
\hline
\end{tabular}

Álcool Etílico Ani dro Combustivel (AEAC)
O AEAC a ser misturado à gasolina automotiva para produção da gasolina $\mathrm{C}$

$\%$ em volume deverá estar em conformidade com o teore a NBR13992 especificação estabele cidos pela legislaçăo em vigor.

\begin{tabular}{|c|c|c|c|}
\hline Massa específica a $20^{\circ} \mathrm{C}$ & $\mathrm{Kg} / \mathrm{m}^{3}$ & Anotar faixa típica 740 e 776 & $\begin{array}{l}\text { NBR } 7148 \\
\text { NBR } 14065 \\
\text { ASTM D } 1298 \\
\text { ASTM D4052 }\end{array}$ \\
\hline Destilação & & & $\begin{array}{l}\text { NBR } 9619 \\
\text { ASTMD } 86\end{array}$ \\
\hline $10 \%$ evaporado, máx. & & 65 & \\
\hline $\begin{array}{l}50 \% \text { evaporado, máx. } \\
90 \% \text { evaporado. }\end{array}$ & ${ }^{\circ} \mathrm{C}$ & $\begin{array}{c}90 \\
120\end{array}$ & \\
\hline PFE, máx. & & 220 & \\
\hline Resíduo & $\%$ em volume & 2 & \\
\hline $\begin{array}{l}\text { No de Octano Motor - } \\
\text { MON, mín. }\end{array}$ & \multirow{2}{*}{ não tem } & 82 & $\begin{array}{l}\text { NBR MB } 457 \\
\text { ASTM D } 2700 \\
\end{array}$ \\
\hline $\begin{array}{l}\text { Índice Antidetonante - } \\
\text { IAD, mín. }\end{array}$ & & $\begin{array}{l}\text { Teor mínimo estabelecido pela } \\
\text { legislaçäo em vigor. }\end{array}$ & $\begin{array}{l}\text { NBR MB } 457 \\
\text { ASTM D2699 } \\
\text { ASTM D2700 }\end{array}$ \\
\hline $\begin{array}{l}\text { Pressão de vapor a } \\
37,8^{\circ} \mathrm{C}\end{array}$ & $\mathrm{kPa}$ & máximo de 69 & $\begin{array}{c}\text { NBR } 4149 \\
\text { NBR } 14156 \\
\text { ASTM D4953 } \\
\text { ASTM D519 } \\
\text { ASTM D5191 } \\
\text { ASTM D5482 }\end{array}$ \\
\hline Goma atual lavada máx. & $\mathrm{mg} / 100 \mathrm{ml}$ & 5 & $\begin{array}{l}\text { NBR } 14525 \\
\text { ASTM D } 381 \\
\end{array}$ \\
\hline $\begin{array}{l}\text { Período de induçăo a } \\
100^{\circ} \mathrm{C} \text {, mín. }\end{array}$ & minutos & 360 & $\begin{array}{l}\text { NBR } 14478 \\
\text { ASTM D525 }\end{array}$ \\
\hline $\begin{array}{l}\text { Corrosidade ao cobre a } \\
50^{\circ} \mathrm{C}, 3 \mathrm{~h} \text {, máx. }\end{array}$ & não tem & 1 & $\begin{array}{l}\text { NBR } 14359 \\
\text { ASTM D130 }\end{array}$ \\
\hline Enxofre, máx. & $\%$ em massa & 0,1 & $\begin{array}{c}\text { NBR } 6563 \\
\text { NBR } 14533 \\
\text { ASTM D } 1266 \\
\text { ASTM D54 } \\
\text { ASTM D4294 } \\
\text { ASTM D3120 } \\
\text { ASTM D2622 }\end{array}$ \\
\hline Benzeno, máx. & $\%$ em volume & 1 & $\begin{array}{l}\text { ASTM D3606 } \\
\text { ASTM D6277 } \\
\text { ASTM D5443 } \\
\text { ASTM D3237 }\end{array}$ \\
\hline Chumbo, máx. & $\mathrm{g} /$ & 0,005 & ASTM D3237 \\
\hline Aditivos & não tem & $\begin{array}{l}\text { Utilização permitida conforme legislação em } \\
\text { vigor, sendo proibidos os aditivos a base de } \\
\text { metais pesados. }\end{array}$ & nãotem \\
\hline Hidrocarbonetos: & $\%$ em volume & & $\begin{array}{l}\text { NBR MB424 } \\
\text { ASTM D1319 }\end{array}$ \\
\hline $\begin{array}{l}\text { Aromáticos, máx } \\
\text { Olefínicos, máx }\end{array}$ & & $\begin{array}{l}45 \\
30 \\
\end{array}$ & \\
\hline
\end{tabular}




\subsubsection{Os aditivos na Gasolina C}

Os aditivos disponíveis na gasolina são geralmente de efeito detergente com o intuito de promover a limpeza das peças metálicas que tem contato direto com o combustível. A utilização em vigor proíbe o uso de aditivos à base de metais pesados.

Atualmente não há uma legislação que determine o uso de aditivos de efeito detergente para toda a Gasolina C comercializada no Brasil. Países como, por exemplo, Estados Unidos, México, Colômbia, Tailândia, China e Índia têm obrigatoriedade legal na adição desse aditivo.

Conforme SA (2008), a inclusão dos aditivos em toda a gasolina comercializada no Brasil traria vantagens contra a adulteração dos combustíveis, pois poderia haver um controle das empresas que enviassem dados conflitantes aos dados dos fabricantes de aditivos.

Além disso, os aditivos detergentes devido às características químicas, contribuem na redução de emissões de poluentes, na melhor lubricidade e estabilidade, e, conseqüentemente, menores tendências na formação de depósitos e corrosividade.

\subsubsection{A análise da gasolina $\mathrm{C}$ pela ANP}

Mensalmente são disponibilizados, via website da ANP, os Boletins da Qualidade dos Combustíveis, de modo que são apresentados os índices de nãoconformidades dos combustíveis comercializados no território nacional.

Conforme os boletins mensais divulgados pela ANP, há quatro maneiras utilizadas para a identificação de alguma não conformidade na Gasolina C. Essa seqüência está de acordo com o grau de complexidade na análise para a identificação. Encontrada uma não conformidade, o teste é finalizado.

A primeira está na análise do teor alcoólico na gasolina. Em seguida, é verificada a curva de destilação, e caso haja alguma evidência da adição de algum solvente, porém, com uma quantidade dentro das especificações da ANP, é feita uma análise do número de octanas. Por último, se o número de octanas estiver de acordo com a especificação, é realizada uma cromatografia gasosa para verificar se há a presença de marcador utilizado nos solventes nacionais e nos importados legalmente. Essa seqüência utiliza-se o critério do custo das análises, do menor para o maior valor para identificação de alguma irregularidade. 
Os marcadores são moléculas orgânicas adicionadas ao solvente em partes por bilhão. Para não interferirem na aplicabilidade dos solventes, os marcadores são projetados de forma a manter suas funções básicas como, por exemplo, em pinturas, vernizes e perfumes (FLUMIGNAM et al, 2007).

Porém, a utilização de marcadores pode causar danos ao produto final conforme a finalidade do solvente. Solventes destinados a algumas aplicações, devido ao processamento químico, não apresentam marcadores (MENDES, 2008).

Desta forma, dependendo do solvente utilizado na adulteração não apresentar o marcador químico, dificilmente será identificada alguma não conformidade na qualidade da gasolina.

No período de janeiro de 2006 a novembro de 2008, os boletins mensais, somente para a gasolina, das adulterações identificadas pela ANP dividem-se da seguinte maneira como mostra o Gráfico 6.

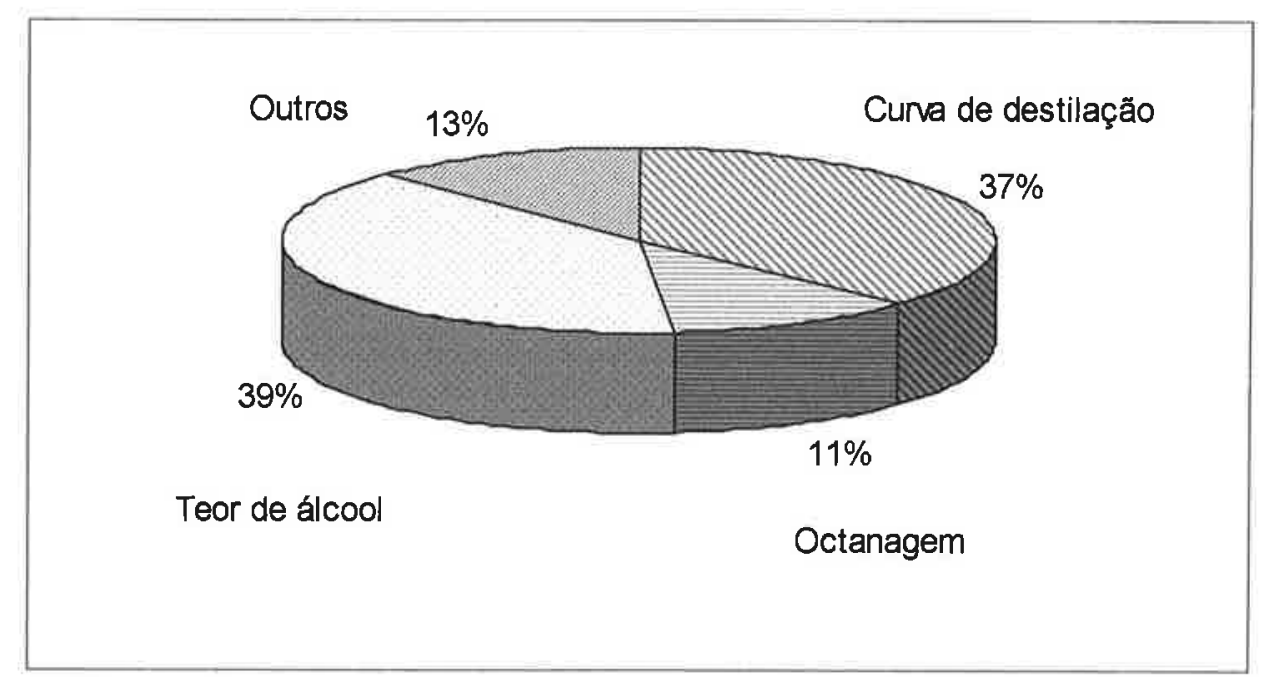

Gráfico 6: Proporção de não conformidades apresentadas no período de janeiro de 2006 a novembro de 2008 (ANP, 2008).

A porcentagem de não conformidades identificadas nas gasolinas analisadas ao longo dos 35 meses teve uma variação tanto na proporção de adulterações como na porcentagem de irregularidades em relação ao número de amostras, conforme os Gráficos 6 e 7. 


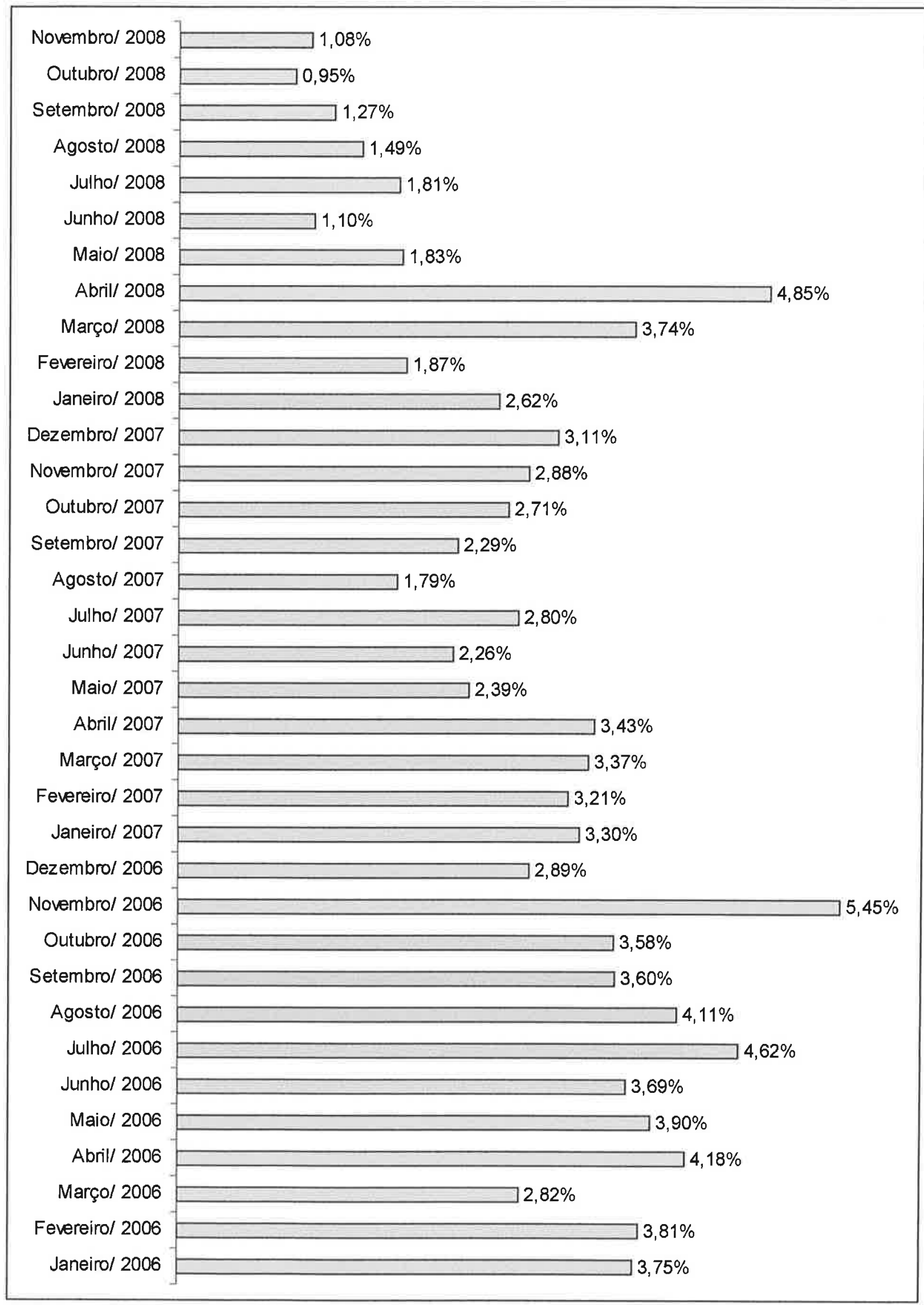

Gráfico 7: Boletins mensais de não conformidades apresentadas no período de janeiro de 2006 a novembro de 2008 (ANP, 2008). 
As porcentagens encontradas nos boletins mensais podem ter grandes variações de adulterações. Enquanto em alguns meses o índice de não conformidades está em torno de $1 \%$, em outros ultrapassam $5 \%$.

Porém, algumas misturas de solventes sem marcadores na Gasolina C, com a manutenção da porcentagem do AEAC na mistura da gasolina, impossibilitam uma análise correta em alguns casos na divulgação dos boletins mensais da ANP.

\section{4 Álcool etílico combustível}

Atualmente são comercializados no Brasil dois combustíveis oxigenados, o álcool etílico anidro carburante, utilizado na mistura da gasolina e o álcool etílico hidratado carburante, comercializado para os veículos exclusivamente a álcool e para os veículos bicombustíveis abastecidos com gasolina e álcool.

Como o álcool etílico hidratado carburante pode apresentar até 7,4\% em massa de água, há entendimentos entre a Petrobras e a União da Agroindústria Canavieira de São Paulo (UNICA) para a produção integral do álcool etílico anidro carburante. A unificação do álcool etílico anidro carburante traria benefícios quanto ao controle nas possiveis adulterações, agregaria maior valor no produto para se tornar uma commodity mundial, reduziria os valores de frete na distribuição sem o transporte de água, diminuiria o ataque corrosivo proveniente da água e reduziria o consumo dos veículos abastecidos exclusivamente a álcool e os bicombustíveis.

Segundo PORTO (2006), mesmo que o álcool etílico anidro carburante custasse cerca de $10 \%$ a mais que o hidratado no período da safra, haveria uma compensação nos benefícios em relação à economia energética.

\subsection{1 Álcool etílico anidro carburante (AEAC)}

O álcool etílico anidro carburante (AEAC) contém um teor alcoólico de no mínimo $99,30{ }^{\circ}$ INPM e uma massa específica de $790,30 \mathrm{Kg} / \mathrm{m}^{3}$ a $20{ }^{\circ} \mathrm{C}$. A gasolina que recebe o AEAC é conhecida também como gasohol. A especificação do AEAC no Brasil segue a Portaria ANP, n 36 de 06 de dezembro de 2005.

As vantagens na adição do AEAC na gasolina, por ser um combustível oxigenado, estão principalmente na redução de emissão dos gases CO e HC. Porém, para que o motor funcione corretamente com o gasohol, devem ser feitas alterações no 
motor principalmente no sistema de alimentação e nos materiais de construção para evitar o ataque corrosivo do álcool. Segundo OWEN et al (1990), há a necessidade de mudar os parâmetros de funcionamento de sistemas de injeção eletrônica e a geometria de componentes de carburadores para compensar a quantidade de oxigênio presente no combustível.

$\mathrm{O}$ etanol tem sua composição química dada pela fórmula molecular $\mathrm{C}_{2} \mathrm{H}_{5} \mathrm{OH}$, enquanto que a gasolina é uma mistura de hidrocarbonetos que, em geral, contém de 4 a 13 carbonos na molécula. Enquanto as porcentagens em peso de carbono, hidrogênio e oxigênio no etanol são, respectivamente, de 52,2\%,13,1\% e 34,7\%, a gasolina possui de 85 a $88 \%$ de carbono e de 12 a $15 \%$ de hidrogênio. (OWEN et al., 1990). Dessa maneira, o oxigênio do etanol substitui uma parte considerável de carbono da gasolina.

A Tabela 2 apresenta a especificação do AEAC.

Tabela 2: Especificação do AEAC. Portaria ANP n 36 de 06/12/2005

\begin{tabular}{|c|c|c|c|}
\hline Característica & Unidade & Especificação & Normas \\
\hline Cor & \multirow{2}{*}{ não tem } & \multirow{2}{*}{$\begin{array}{l}\text { Limpida e isento de impurezas. Deveser } \\
\text { adicionado o teor de } 15 \mathrm{mg} / \text { proporcionando a } \\
\text { cor laranja }\end{array}$} & \multirow{2}{*}{ Visual } \\
\hline Aspecto & & & \\
\hline $\begin{array}{l}\text { Ácidez total (como o } \\
\text { ácido acético), máx. }\end{array}$ & $\mathrm{ml} / \mathrm{litro}$ & 30 & $\begin{array}{c}\text { NBR } 9986 \\
\text { ASTM D1613 }\end{array}$ \\
\hline $\begin{array}{l}\text { Condutividade } \\
\text { elétrica, máx. }\end{array}$ & $\mu \mathrm{S} / \mathrm{m}$ & 500 & $\begin{array}{c}\text { NBR } 10547 \\
\text { ASTM D1125 }\end{array}$ \\
\hline Massa específica à $20^{\circ} \mathrm{C}$ & $\mathrm{Kg} / \mathrm{m}^{3}$ & 791,5 & $\begin{array}{c}\text { NBR } 5592 \\
\text { ASTM D4052 } \\
\end{array}$ \\
\hline Teor alcoólico & ㅇNPM & mín. de 99,3 & NBR5592 \\
\hline Potencial hidrogeniônico & $\mathrm{pH}$ & não tem & NBR 10891 \\
\hline $\begin{array}{l}\text { Resíduo por evaporação } \\
\text { máx. }\end{array}$ & $\mathrm{mg} / 100 \mathrm{Ml}$ & não tem & NBR 8644 \\
\hline $\begin{array}{l}\text { Teor de hidrocarbonetos, } \\
\text { máx. }\end{array}$ & $\%$ em volume & 3,0 & NBR 13993 \\
\hline Íon Cloreto, máx. & $\mathrm{ml} / \mathrm{Kg}$ & năo tem & $\begin{array}{l}\text { NBR } 10894 \\
\text { NBR } 10895 \\
\text { ASTM D512 } \\
\end{array}$ \\
\hline Teor de etanol, mín. & $\%$ em volume & 99,6 & ASTM D5501 \\
\hline Íon Sulfato, máx. & $\mathrm{mg} / \mathrm{Kg}$ & não tem & $\begin{array}{l}\text { NBR } 10894 \\
\text { NBR } 12120\end{array}$ \\
\hline Ferro, máx. & $\mathrm{mg} / \mathrm{Kg}$ & não tem & NBR 11331 \\
\hline Sódio, máx. & $\mathrm{mg} / \mathrm{Kg}$ & não tem & NBR 10422 \\
\hline Cobre, máx. & $\mathrm{mg} / \mathrm{Kg}$ & 0,07 & NBR 10893 \\
\hline
\end{tabular}

A quantidade de oxigênio no etanol torna a relação estequiométrica arcombustível menor e gera uma mistura pobre quando adicionado à gasolina. As 
características de volatilidade também se modificam com a mistura do etanol na gasolina e, conseqüentemente, surgem diferenças nos desempenhos de um motor ao consumir a gasolina pura e uma "gasolina oxigenada".

A pressão de vapor de uma "gasolina oxigenada" varia de acordo com o tipo de composto oxigenado adicionado. Por exemplo, a adição de metanol que possui uma pressão de vapor maior que o etanol, gera dificuldades ainda maiores que o etanol para a evaporação da mistura com o aumento da porcentagem misturada à gasolina.

O Gráfico 8 mostra o efeito da concentração de oxigenados na pressão de vapor de misturas com gasolina.

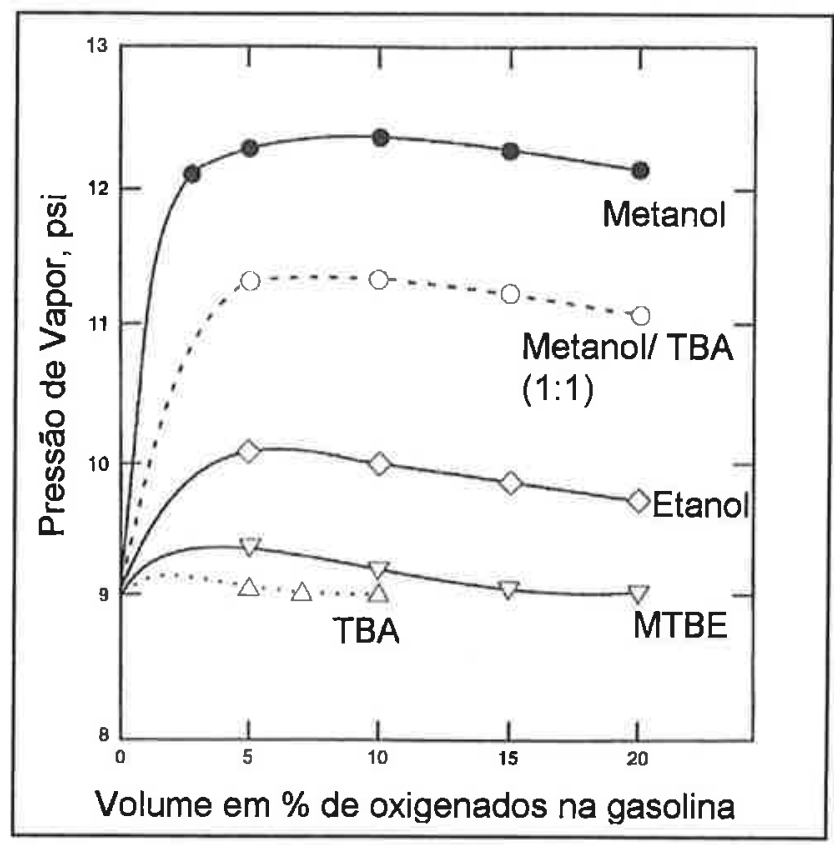

Gráfico 8: Efeito da concentração de oxigenados na pressão de vapor de misturas com gasolina (OWEN et al., 1990).

Em contrapartida, o número de octanas aumenta com a adição do etanol. O etanol possui número de octano RON que varia entre 120 e 135 octanas e número de octano MON que varia entre 100 e 106 (OWEN et al., 1990).

O Gráfico 9 apresenta a tolerância de água na mistura de metanol e etanol com $26 \%$ de aromático em volume e sem a presença de cossolvente. 


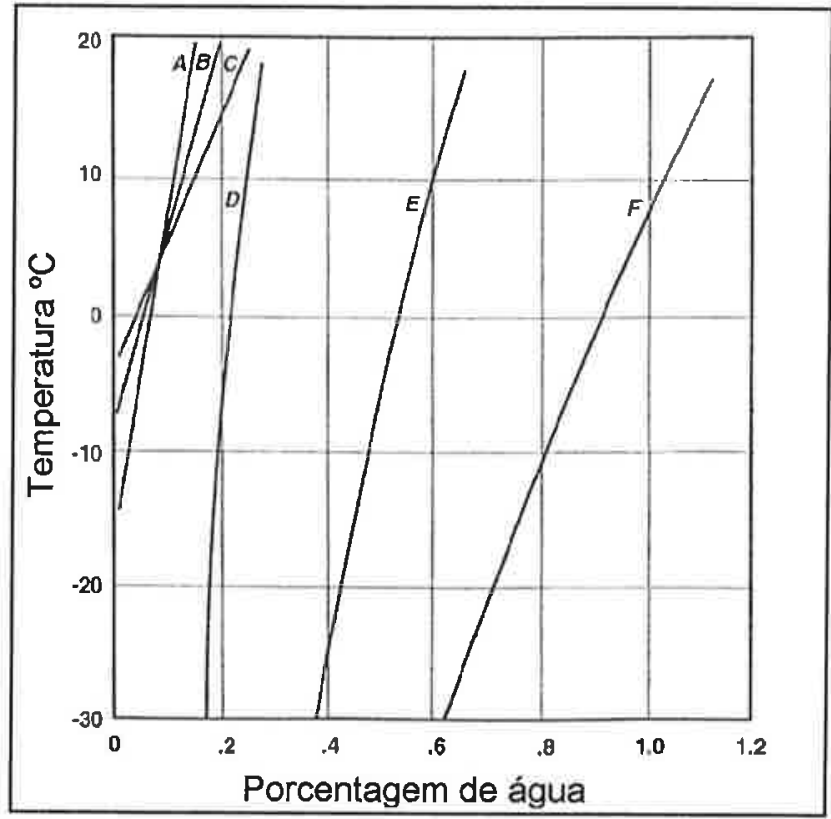

Gráfico 9: Tolerância de água na mistura de metanol e etanol com uma gasolina com $26 \%$ de aromático em volume e sem a presença de cossolvente (OWEN et al, 1990).
Metanol

A $-10 \%$ em vol.

B $-15 \%$ em vol.

C $-20 \%$ em vol.

\section{Etanol}

$D-10 \%$ em vol.

E - $15 \%$ em vol.

F- $20 \%$ em vol.

Enquanto o etanol é totalmente hidrófilo, a gasolina não se mistura com a água. Porém, o etanol se mistura com os hidrocarbonetos. Dessa maneira, dependendo da porcentagem de água no etanol, pode ocorrer a separação do combustível em duas fases. Segundo OWEN et al (1990), antes do combustível se apresentar em duas fases, há uma quantidade tolerável de água na mistura do combustivel oxigenado que depende da temperatura, da composição dos hidrocarbonetos da gasolina, do tipo e concentração do álcool e da presença de cossolventes.

A tolerância de água na mistura de um combustível oxigenado varia também da temperatura e da quantidade de hidrocarbonetos aromáticos presentes na gasolina misturada, conforme mostra o Gráfico 10. 


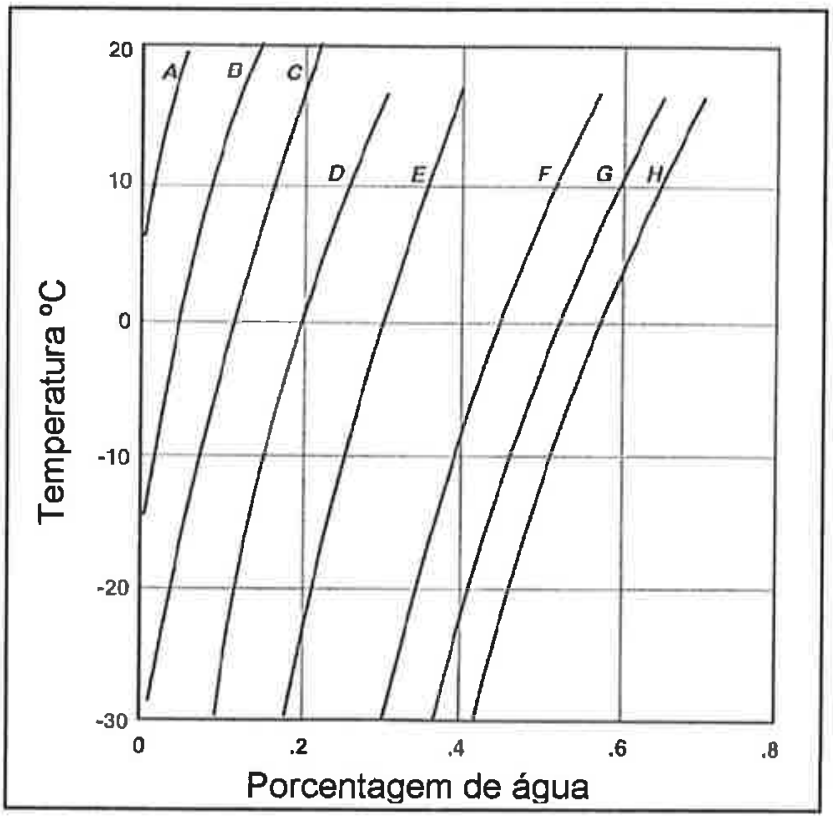

\begin{tabular}{|c|c|c|c|}
\hline & $\begin{array}{c}\text { AROM. } \\
\text { na } \\
\text { gasolina } \\
\text { Vol. \% }\end{array}$ & $\begin{array}{c}\text { MeOH } \\
\text { na } \\
\text { mistura } \\
\text { Vol \% }\end{array}$ & $\begin{array}{c}\text { EtOH } \\
\text { na } \\
\text { mistura } \\
\text { Vol. \% }\end{array}$ \\
\hline A & 14 & 10 & - \\
\hline B & 26 & 10 & - \\
\hline C & 38 & 10 & - \\
\hline D & 26 & 6,7 & 3,3 \\
\hline E & 26 & 3,3 & 6,7 \\
\hline F & 14 & - & 10 \\
\hline G & 26 & - & 10 \\
\hline H & 38 & - & 10 \\
\hline
\end{tabular}

Gráfico 10: Tolerância de água numa mistura de metanol e etanol de $10 \%$ na gasolina, com diferentes quantidades de aromáticos (OWEN et al., 1990).

O Gráfico 11, a seguir, mostra como a adição do cossolvente no combustível oxigenado aumenta a tolerância de água.

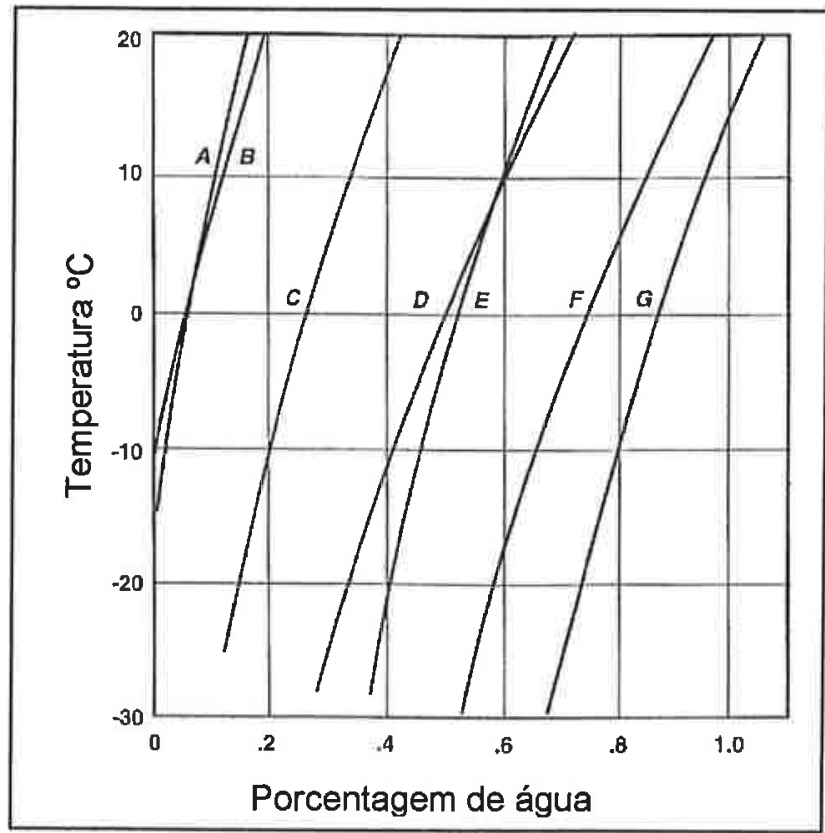

\begin{tabular}{|c|c|c|c|}
\hline & $\begin{array}{c}\mathrm{MeOH} \\
\text { na } \\
\text { mistura } \\
\text { Vol \% }\end{array}$ & $\begin{array}{c}\text { EtOH } \\
\text { na } \\
\text { mistura } \\
\text { Vol. \% }\end{array}$ & $\begin{array}{c}\text { Cosolvente } \\
\text { Vol. \% }\end{array}$ \\
\hline A & 10,0 & - & - \\
\hline B & 13,2 & - & - \\
\hline C & 10,0 & - & $3,2 \mathrm{iBuOH}$ \\
\hline D & 14,0 & - & $6,0 \mathrm{iBuOH}$ \\
\hline E & - & 10,0 & - \\
\hline F & - & 13,2 & - \\
\hline G & - & 10,0 & $3,2 \mathrm{iBuOH}$ \\
\hline
\end{tabular}

Gráfico 11: Efeito do cossolvente na tolerância de água na mistura de metanol e etanol com $26 \%$ de aromáticos na gasolina (OWEN et al., 1990).

Outro fator ao qual se deve dar atenção diz respeito aos depósitos formados particularmente nas válvulas e coletor de admissão que aumentam com o uso do combustivel oxigenado. A mistura da gasolina com o AEAC aumenta a solubilidade da 
goma e conseqüentemente aumenta a tendência de formação de depósitos no sistema de admissão, conforme mostra o Gráfico 12.

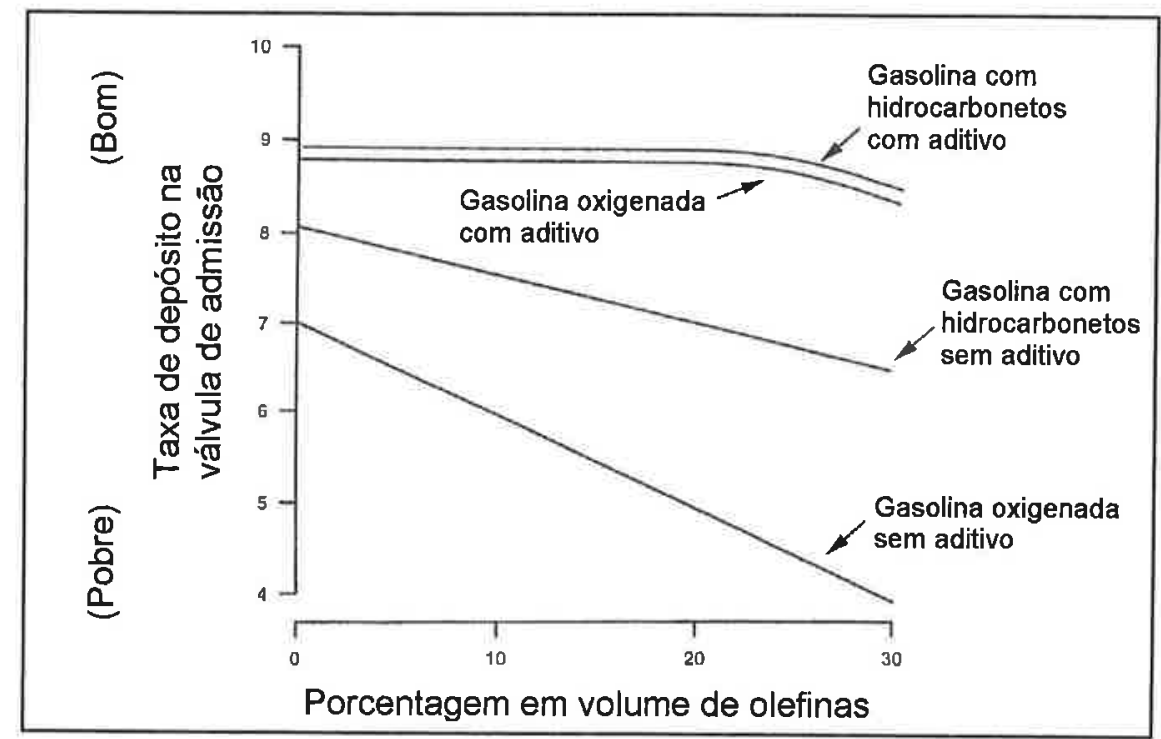

Gráfico 12: Influência dos oxigenados e aditivos na limpeza do sistema de admissão (OWEN et al., 1990).

A utilização de um combustível com maior concentração de etanol pode gerar desprendimento de goma e outros tipos de sedimentos, promovendo o bloqueio dos filtros. Mudanças no abastecimento do tanque de combustível é o principal efeito para dissolver a goma já existente no sistema de alimentação.

Porém, segundo OWEN et al (1990), a combustão de um motor preparado para funcionar com a presença de oxigenados melhora parâmetros de desempenho tal como redução comprovada de emissão de CO.

\subsection{2 Álcool etílico hidratado carburante (AEHC)}

O álcool etílico hidratado carburante (AEHC) é o combustivel conhecido como E100 (100\% de etanol). Devido à alta concentração de oxigenados nesse combustivel, os efeitos no desempenho, momento de força, partida a frio, desgastes e emissões são mais perceptíveis que o AEAC misturado com a gasolina.

A especificação segue a mesma Portaria ANP, $n^{\circ} 36$ de 06 de dezembro de 2005 que o AEAC, porém com algumas mudanças.

Enquanto que o AEAC tem um teor alcoólico de no mínimo 99,3 ${ }^{\circ}$ INPM, o AEHC está entre 92,6 a 93,8 'INPM. Conseqüentemente, há diferenças na especificação da massa específica controlada a $20^{\circ} \mathrm{C}$ entre eles. 
A máxima acidez total, condutividade elétrica e teor de hidrocarbonetos são as mesmas para ambas as especificações do etanol, porém a diferença do teor alcoólico tem uma pequena variação em volume de combustível.

As quantidades máximas de íon sulfato, de ferro e de sódio são controladas somente no $A E H C$, sendo que o AEAC é controlada a quantidade de cobre por espectrofotometria pois, em geral, a produção e o transporte se fazem com a utilização de tubulações e equipamentos que contém esse metal ou suas ligas.

O potencial hidrogeniônico $(\mathrm{pH})$ deve estar entre 6,0 a 8,0.

A presença de resíduos de evaporação é verificada somente para AEHC (máximo de $5 \mathrm{mg} / 100 \mathrm{ml}$ ).

A Tabela 3 apresenta a especificação do AEHC.

Tabela 3: Especificação do AEHC. Portaria ANP n 36 de 06/12/2005.

\begin{tabular}{|c|c|c|c|}
\hline Característica & Unidade & Especificação & Normas \\
\hline Cor & \multirow{2}{*}{ não tem } & \multirow{2}{*}{ Limpida e isento de impurezas. } & \multirow{2}{*}{ Visual } \\
\hline Aspecto & & & \\
\hline $\begin{array}{l}\text { Ácidez total (como o ácido } \\
\text { acético), máx. }\end{array}$ & $\mathrm{ml} / \mathrm{litro}$ & 30 & $\begin{array}{c}\text { NBR } 9986 \\
\text { ASTMD1613 }\end{array}$ \\
\hline $\begin{array}{l}\text { Condutividade el étrica, } \\
\text { máx. }\end{array}$ & $\mu S / m$ & 500 & $\begin{array}{c}\text { NBR } 10547 \\
\text { ASTMD1 } 125 \\
\end{array}$ \\
\hline Massa especifica à $20^{\circ} \mathrm{C}$ & $\mathrm{Kg} / \mathrm{m}^{3}$ & 807,6 a 811,0 & $\begin{array}{c}\text { NBR } 5592 \\
\text { ASTM D4052 } \\
\end{array}$ \\
\hline Teor alcoólico & 이PM & 92,6 a 93,8 & NBR5592 \\
\hline Potencial hidrogeniônico & $\mathrm{pH}$ & 6,0 a 8,0 & NBR 10891 \\
\hline $\begin{array}{l}\text { Resíduo por evaporação } \\
\text { máx. }\end{array}$ & $\mathrm{mg} / 100 \mathrm{Ml}$ & 5 & NBR 8644 \\
\hline $\begin{array}{l}\text { Teor de hidrocarbonetos, } \\
\text { máx. }\end{array}$ & $\%$ em volume & 3,0 & NBR 13993 \\
\hline Íon Cloreto, máx. & $\mathrm{ml} / \mathrm{Kg}$ & 1 & $\begin{array}{l}\text { NBR } 10894 \\
\text { NBR } 10895 \\
\text { ASTM D5 } 12 \\
\end{array}$ \\
\hline Teor de etanol, min. & $\%$ em volume & 95,1 & ASTM D5501 \\
\hline Ion Sulfato, máx. & $\mathrm{mg} / \mathrm{Kg}$ & 4 & $\begin{array}{l}\text { NBR } 10894 \\
\text { NBR } 12120 \\
\end{array}$ \\
\hline Ferro, máx. & $\mathrm{mg} / \mathrm{Kg}$ & 5 & NBR 11331 \\
\hline Sódio, máx. & $\mathrm{mg} / \mathrm{Kg}$ & 2 & NBR 10422 \\
\hline Cobre, máx. & $\mathrm{mg} / \mathrm{Kg}$ & não tem & NBR 10893 \\
\hline
\end{tabular}

O uso do AEHC como combustível associa vantagens e desvantagens. 
Segundo OWEN et al (1990), o álcool queima mais rápido que a gasolina e permite a evolução do momento de força (torque) de forma mais eficiente, além de gerar maiores pressões durante a combustão no cilindro.

O etanol tem uma excelente propriedade anti-detonante para motores com altas taxas de compressão. Uma conseqüência importante é a possibilidade de uso de maiores razões de compressão nos motores que, potencialmente aumentam suas eficiências indicadas.

A principal desvantagem está no desgaste do motor entre os anéis do pistão e o cilindro. Conforme OWEN et al (1990), há duas linhas que permitem explicar o desgaste. A primeira relata que parte da camada do filme de óleo pode ser "lavada" pelo álcool durante a partida a frio. A segunda explica que o desgaste dos anéis do pistão com o cilindro é decorrente dos ácidos fórmico e perfórmico formados durante a combustão, que poderia corroer $o$ aço.

As pressões de vapor dos hidrocarbonetos na gasolina são em grande parte superiores à do etanol. Por isso, o sistema de partida a frio requer auxílio de combustíveis com cadeias de carbono menores para facilitar o acionamento inicial do motor. A energia necessária para vaporizar o etanol é, em grande parte, superior àquela necessária aos hidrocarbonetos presentes na gasolina. Portanto, a partida a frio é mais difícil quando se utiliza somente o E100.

Dependendo da temperatura ambiente, o período de tempo necessário para o aquecimento de um motor movido a etanol é maior do que aqueles movidos a gasolina. $\mathrm{O}$ baixo poder calorífico do etanol requer tanques de combustíveis maiores ou freqüentes abastecimentos (POULTON, 1994).

Outro fator que deve ser levado em consideração é que o álcool, comparado com a gasolina, tem baixas viscosidade e lubricidade que podem causar desgastes excessivos no sistema de alimentação.

\subsection{Solventes}

Os solventes são produtos que tem a capacidade de dissolver outros produtos sem modificar-Ihes as propriedades químicas (ANP, 1999). Os grupos de hidrocarbonetos usados supostamente na adulteração da gasolina enquadram-se nesta classificação e se sub-classificam em, parafínicos, alifáticos, naftênicos e aromáticos. 
Os alifáticos são solventes de cadeias abertas ou fechadas saturadas que possuem poderes de solvência e volatilidade relativamente baixos. Exemplos de alifáticos são: aguarrás, hexano, querosene e solvente de borracha. Devido às suas características, a adição desses solventes na gasolina $\mathrm{C}$ é de identificação rápida $\mathrm{e}$ simples por meio da curva de destilação.

Os naftênicos têm poder de solvência maior e menor volatilidade que os alifáticos, além de um elevado número de octanas.

Os aromáticos baseiam-se em anel insaturado de seis átomos de carbono e tem um poder de solvência e odor superior aos alifáticos. Exemplos de aromáticos são: benzeno, tolueno e xileno. Os solventes aromáticos adicionados na gasolina $\mathrm{C}$ geram uma formulação mais eficiente à primeira percepção, devido ao maior número de octanas que incorpora ao combustivel.

Sendo a gasolina formada por uma grande variedade de naftas e como os solventes do grupo dos hidrocarbonetos se originam também de naftas, a adição dentro de certos limites de um determinado teor de um solvente à gasolina como, por exemplo, o xileno, não deverá comprometer a qualidade do combustível (ANP, 1999).

\subsubsection{Os solventes na Gasolina C}

Conforme a tabela abaixo, alguns solventes podem ser adicionados à Gasolina C sem uma detecção prévia, por exemplo, com a análise do teor alcoólico. Porém, as propriedades químicas fora de especificação são facilmente identificadas com uma análise da curva de destilação.

Danos maiores só serão observados após vários abastecimentos com combustível adulterado. Rendimento insatisfatório, perda da potência do motor, aumento no consumo são sintomas considerados de curto prazo (SOUZA NETO et al, 2005).

A Tabela 4 busca mostrar a influência da presença de alguns tipos de solventes na curva de destilação e na octanagem da Gasolina C. 
Tabela 4. Comparação da destilação e a octanagem da Gasolina C com alguns tipos de solventes (ANP, 1999).

\begin{tabular}{lccccccc}
\hline $\begin{array}{c}\text { Destilação } \\
\begin{array}{c}\text { Evaporado } \\
\text { máximo }\end{array}\end{array}$ & ANP & Média & $\begin{array}{c}\text { Giluentes } \\
\text { de tintas }\end{array}$ & $\begin{array}{c}\text { Solvente } \\
\text { borracha }\end{array}$ & $\begin{array}{c}\text { Solvente } \\
\text { para } \\
\text { extração } \\
n^{\circ} 5\end{array}$ & Xileno & Tolueno \\
\hline Ponto Inicial de Ebulição & - & - & 107 & 52 & 71 & 135 & 110,2 \\
\hline $10 \%$ & 70 & 57 & 118 & 71 & 81 & 137 & - \\
\hline $50 \%$ & 140 & 100 & 122 & 88 & 87 & 138 & 110,5 \\
\hline $90 \%$ & 200 & 175 & 131 & 113 & 101 & 140 & - \\
\hline Ponto Final de Ebulição & 220 & 212 & 142 & 128 & 120 & 153 & 111 \\
\hline Resíduo \% & 2,0 & - & 1,5 & 1,0 & 1,0 & - & - \\
\hline MON & $80(\mathrm{~min})$ & 82 & $51.4^{*}$ & $62.5^{*}$ & $61.8^{*}$ & 102,5 & 103,5 \\
\hline RON & 94 & 94 & $70.7^{*}$ & $78.5^{*}$ & $92.7^{*}$ & 116,4 & 120 \\
\hline (RON + MON) /2 & 87 (min) & 88 & 61 & 70,5 & 77,3 & 111 & 112 \\
\hline
\end{tabular}

* Cálculos teóricos conforme correlação de octanagem com ponto de ebulição médio para naftas de destilação direta em Nelson - Petroleum Refinery Engineering $4^{a}$ edição. Ponto de ebulição médio de acordo com o método de Maxwell para frações leves de petróleo.

A contaminação ao meio ambiente devida à emissão de poluentes, e até a evaporação do combustível adulterado no abastecimento do veículo pode comprometer a saúde de quem manuseia esse produto.

Os hidrocarbonetos parafínicos e aromáticos são utilizados na adulteração de gasolina por solventes. Os solventes parafínicos não são detectados facilmente, pois são compostos que está na mesma faixa de destilação da gasolina (AZEVEDO et al., 2004). Dessa forma, dependendo do solvente a ser adicionado à gasolina, é possível uma adulteração mais complexa de modo que a análise da gasolina dificilmente será identificada em alguma irregularidade.

Segundo estudo de Almeida et al (2003), é possível formular uma Gasolina C utilizando os solventes comercializados no mercado nacional sem a necessidade de ao menos fazer uma mistura com a própria Gasolina C.

No Gráfico 13 há uma mistura de solventes que consegue alcançar uma curva de destilação especificada pela ANP na formulação da Gasolina C. Dessa maneira, os marcadores de solventes são essenciais para inibir a prática comum na adulteração da Gasolina C. 


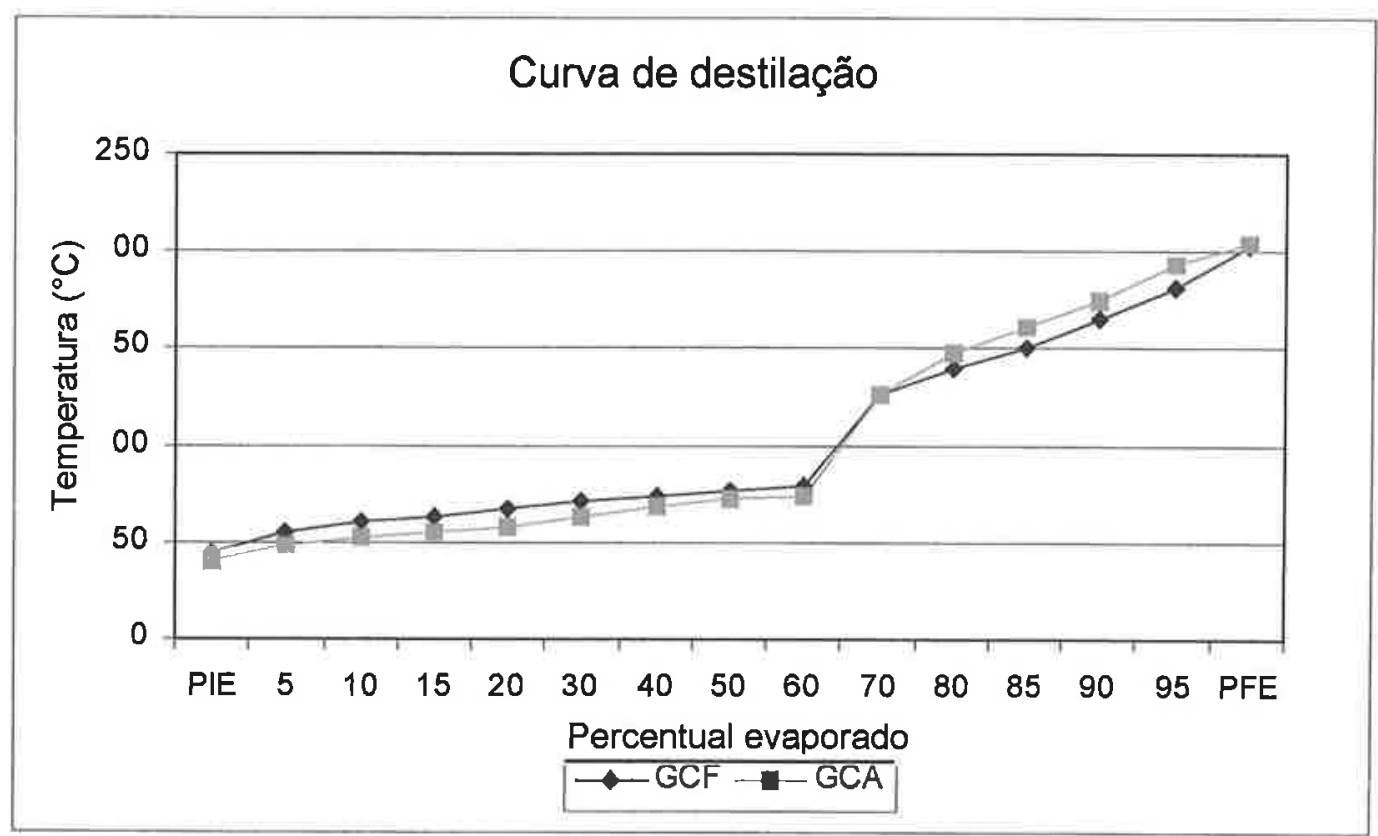

Gráfico 13: Comparativo de curvas de destilação para gasolina formulada com solventes (GCF) e gasolina tipo "C" comum (GCA) (ALMEIDA et al, 2003).

\subsubsection{O solvente C-9}

Em estudo realizado por Takeshita (2006), é possível fazer misturas de Gasolina C com até $30 \%$ de adição de solvente AB-9, 20\% de solvente de aguarrás e $2 \%$ de óleo diesel, sem que sejam detectados pelos testes efetuados pela ANP.

A curva de destilação do solvente $A B 9$, também conhecido como $C-9$ por ser uma cadeia molecular média com nove átomos de carbono, apresenta uma curva de destilação estreita, conforme a Tabela 5 , de modo que a adição na Gasolina $\mathrm{C}$, em quantidades controladas, permite uma adulteração complexa para identificação.

O solvente C-9 pertence aos hidrocarbonetos aromáticos e tem grande resistência à detonação. Em contra partida, há a tendência de gerar mais depósitos de carbono durante a queima no motor e, conseqüentemente, a emissão de mais fumaça.

Na coleta de cinqüenta amostras no estado da Bahia no estudo realizado por Oliveira et al (2004), onze amostras estavam fora da especificação. Porém, quatro delas estavam em conformidade com o método e especificação da ANP. 
Tabela 5: Curva de destilação do solvente AB9 (TAKESHITA, 2006)

\begin{tabular}{cc}
\hline Volume destilado (\%) & Temperatura ${ }^{\circ} \mathrm{C}$ \\
\hline Ponto inicial de ebuliçăo & 155,1 \\
\hline $5 \%$ & 160,4 \\
\hline $10 \%$ & 160,9 \\
\hline $15 \%$ & 161,2 \\
\hline $20 \%$ & 161,4 \\
\hline $30 \%$ & 161,8 \\
\hline $40 \%$ & 162,2 \\
\hline $50 \%$ & 162,8 \\
\hline $60 \%$ & 163,4 \\
\hline $70 \%$ & 164,0 \\
\hline $80 \%$ & 164,9 \\
\hline $85 \%$ & 165,5 \\
\hline $90 \%$ & 166,5 \\
\hline $95 \%$ & 168,6 \\
\hline Ponto final de ebulição & 174,4 \\
\hline Resíduo (ml) & 1,5 \\
\hline Recuperado (\%Vol.) & 97,5 \\
\hline Perdas (ml) & 1,0 \\
\hline
\end{tabular}

2.6.3 O marcador no solvente

Para coibir a utilização de solventes como, por exemplo, o C-9, foi criado a Portaria da ANP $n^{\circ} .274 / 2001$, a utilização de marcador com uma quantidade inferior a $1 \mathrm{ppm}$ em todos os solventes comercializados no território nacional.

Dependendo da utilização do solvente há algumas exceções na introdução de marcadores. Dessa maneira, o número de exceções na marcação de solventes dificulta o controle pela ANP na comercialização do produto. O próprio produtor determina quais caminhões serão ou não marcados conforme o destino do solvente (MENDES, 2008).

2.6.4 Aplicação dos solventes no mercado nacional

Os principais solventes encontrados no mercado nacional e suas aplicações são: solvente para borracha, utilizado para tintas, adesivos, colas, borracha, cera, 
thinner, resinas, lacas e limpeza; xileno ou xilol para tintas, adesivos, colas, borracha, lubrificantes, verniz, massa rápida, primmer, têxtil, pesticidas e química; tolueno ou toluol para tintas, adesivos, colas, borracha, verniz, esmalte, colas de neoprene, lubrificantes, explosivos, massa rápida, primmer, lacas, thinner, selantes e química; benzeno ou benzol para plástico, têxtil, química e farmacêutica; hexano para tintas, adesivos, colas, borracha, ceras, desengraxantes, couro, thinner e seladoura; diluente de tintas para tintas automotivas, thinner, gráfica e nitrosintéticas; solvente para extração $n^{\circ} 5$ para dissolvente de borracha, removedor de manchas gordurosas, diluentes de tintas e vernizes, adesivos e fitas adesivas; rafinado petroquímico para adesivos e colas; AB-9 ou C-9 para tintas, adesivos, colas, borracha, resinas, lacas, massa rápida e primmer; $A B-10$ para tinta automotiva, borracha, thinner, resinas e lacas; aguarrás para tintas, borracha, primmer, cera, massa rápida e de polimento, thinner, têxtil, limpeza e lavagem a seco; querosene para tintas, adesivos, colas para calçados, thinner, limpeza, lubrificantes e graxa; Signal Oil para tintas gráficas, lubrificantes e graxas. 


\section{DESCRIÇÃO DA METODOLOGIA}

Para atingir os objetivos gerais e específicos foram adotados os seguintes procedimentos.

\subsection{Seleção dos motores de combustão interna}

Os motores selecionados para a realização desse trabalho, em número de três foram motores carburados de $125 \mathrm{~cm}^{3}$ de cilindrada, sem dispositivos de póstratamento, que equipam motocicletas. Foram retirados da linha de montagem no mesmo período de fabricação (outubro de 2006), sendo que já eram de modelo 2007.

O mesmo carburador, a mesma vela de ignição e o mesmo conjunto filtrante para de ar foram usados nos três motores no período de amaciamento, buscando reduzir a interferência das tolerâncias de fabricação desses componentes no desempenho dos motores. Também se utilizou o mesmo escapamento para os três motores com a inclusão de uma sonda lâmbda para medição da relação arcombustível. O escapamento não apresenta catalisador e nem sistema de indução de ar.

Nos testes de durabilidade, cada motor utilizou um carburador e uma vela de ignição com a mesma especificação de fábrica para o combustível E25. Os três carburadores, um para cada motor, foram enquadrados numa mesma especificação. $A$ caixa, o filtro de ar e o escapamento do período de amaciamento foram mantidos.

\subsection{Parâmetros do motor de 125 cc para motocicleta}

O motor utilizado no experimento é fornecido para três modelos e sete versões nacionais, entre outras para exportação, produzida pela Yamaha Motor da Amazônia Ltda.

O sistema de lubrificação é projetado de forma que o óleo do motor é utilizado para lubrificar o sistema de transmissão, sistema de embreagem e o próprio sistema de propulsão.

Na região inferior da carcaça do motor, local onde fica a transmissão, existe um respiro sem válvula conectado na caixa do filtro de ar fazendo com que os gases que passam pelo respiro do motor se dirijam para a caixa do filtro de ar. Desta forma, 
os gases de blow-by provenientes do motor são queimados na câmara de combustão antes de ser eliminados para o ambiente, como apresentado na Figura 5.

O filtro de ar não requer substituição, somente limpeza. É composto por uma tela metálica e por duas espumas umedecidas com óleo do motor nas verificações e limpezas periódicas, como mostra na Figura 6 . No fundo da caixa filtro de ar há uma mangueira de dreno para eliminação, durante as revisões periódicas, do óleo lubrificante acumulado.

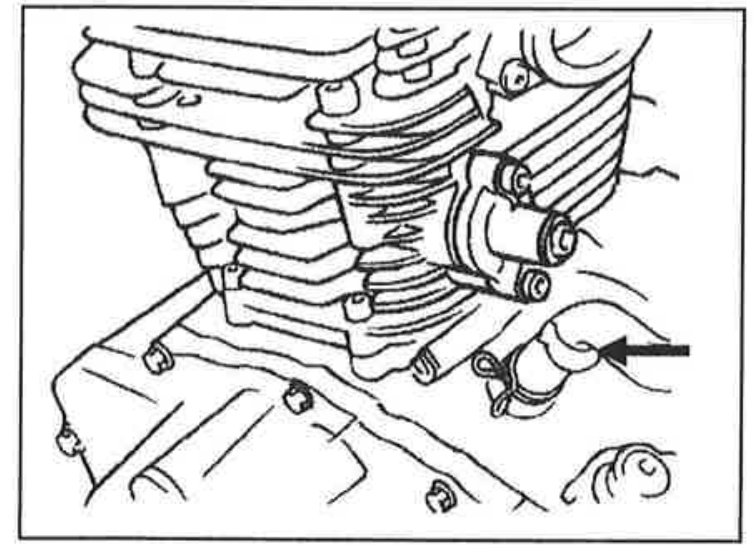

Figura 5: Respiro do cárter do motor (PUBLICAÇĀO YAMAHA, 2000).

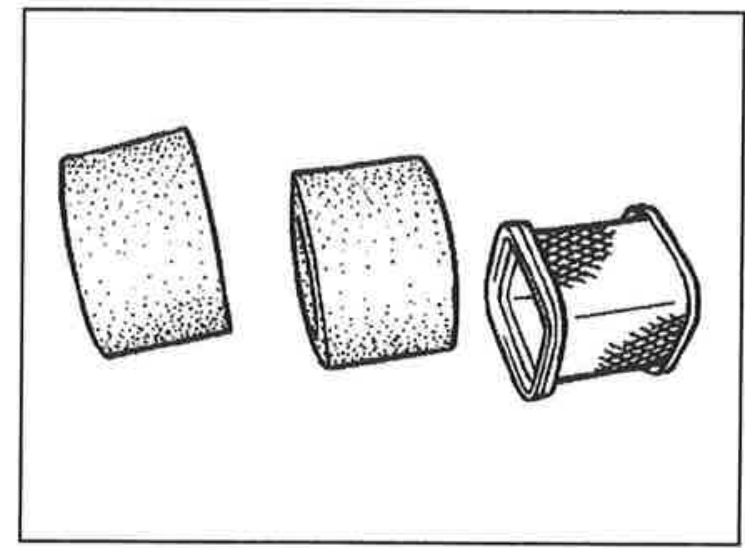

Figura 6: Filtro de ar (PUBLICAÇÃO YAMAHA, 2000).

O óleo é filtrado por um filtro rotativo (que não exige manutenção), como apresenta a Figura 7 e 8 , que tem a mesma rotação do virabrequim, está fixado ao próprio eixo e impede que partículas do óleo passem pelo filtro, utilizando o princípio da inércia. 


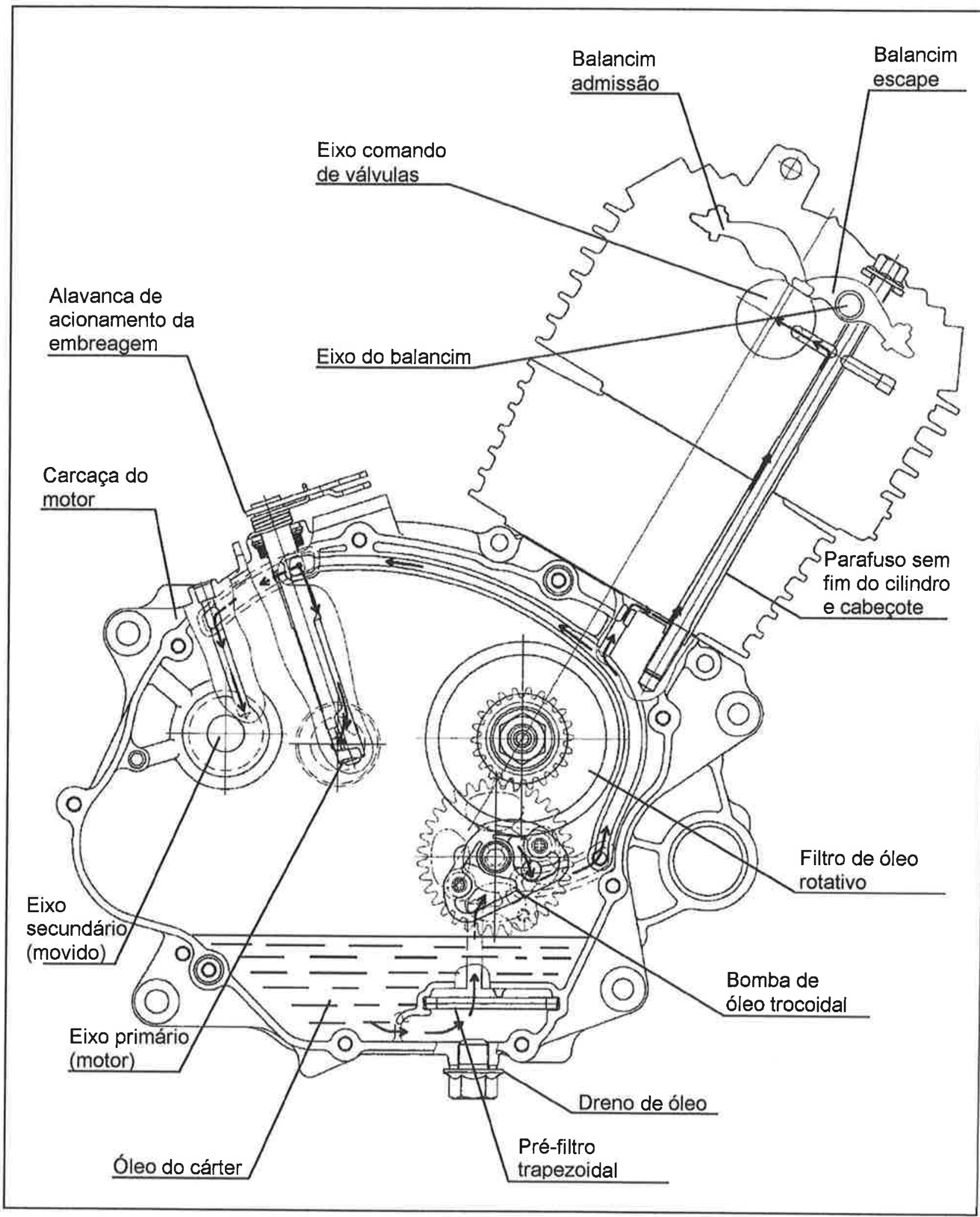

Figura 7: Vista lateral direita do sistema de lubrificação do motor (PUBLICAÇÃO YAMAHA, 2000). 


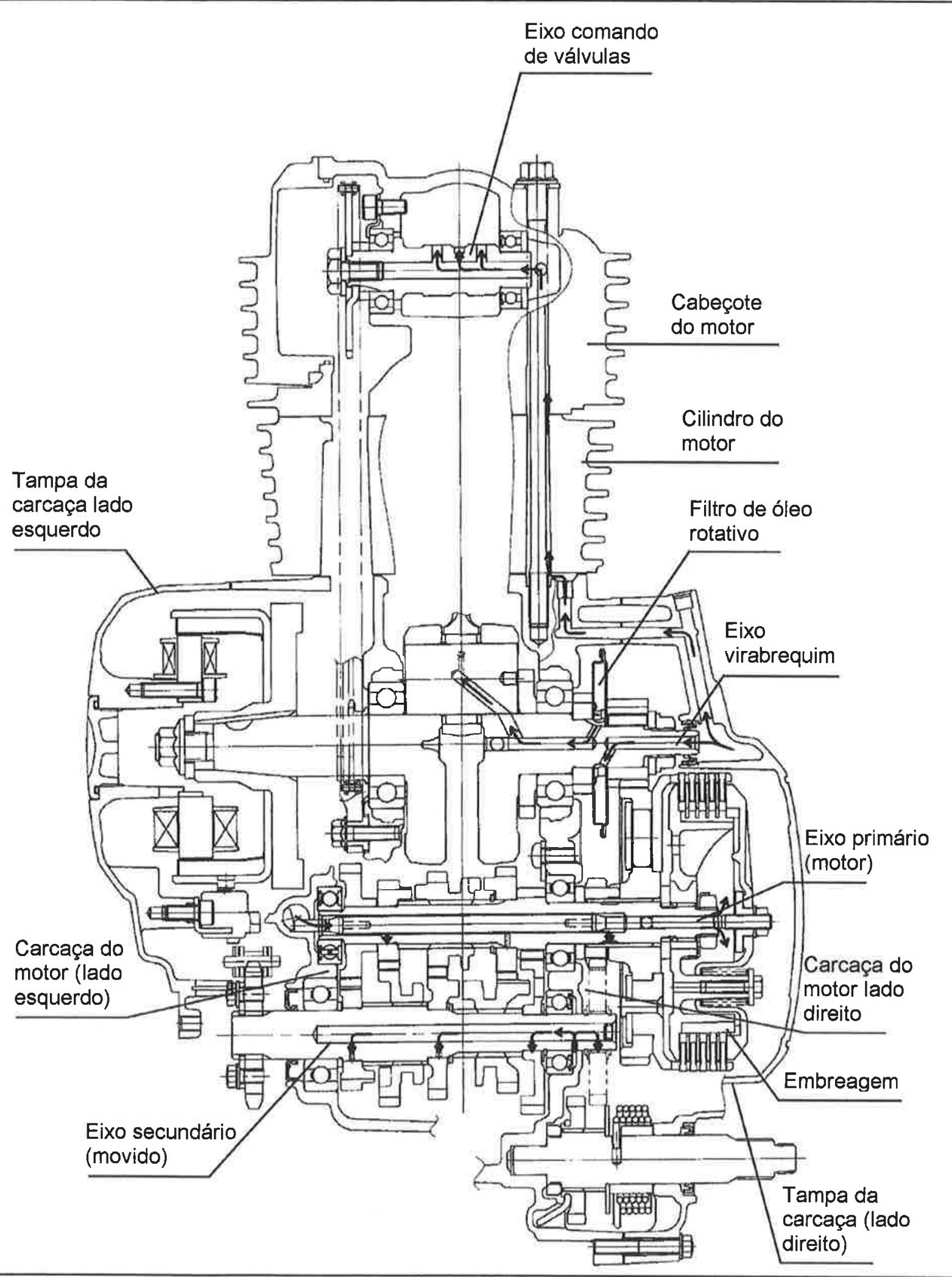

Figura 8: Vista frontal do sistema de lubrificação do motor (PUBLICAÇÃO YAMAHA, 2000).

O fornecimento da mistura combustível-ar é feita por um carburador, como mostra na Figura 9, cujo acelerador aciona o pistonete do venturi variável que define as quantidades de ar e de combustível dosado, conforme a solicitação do motor. 


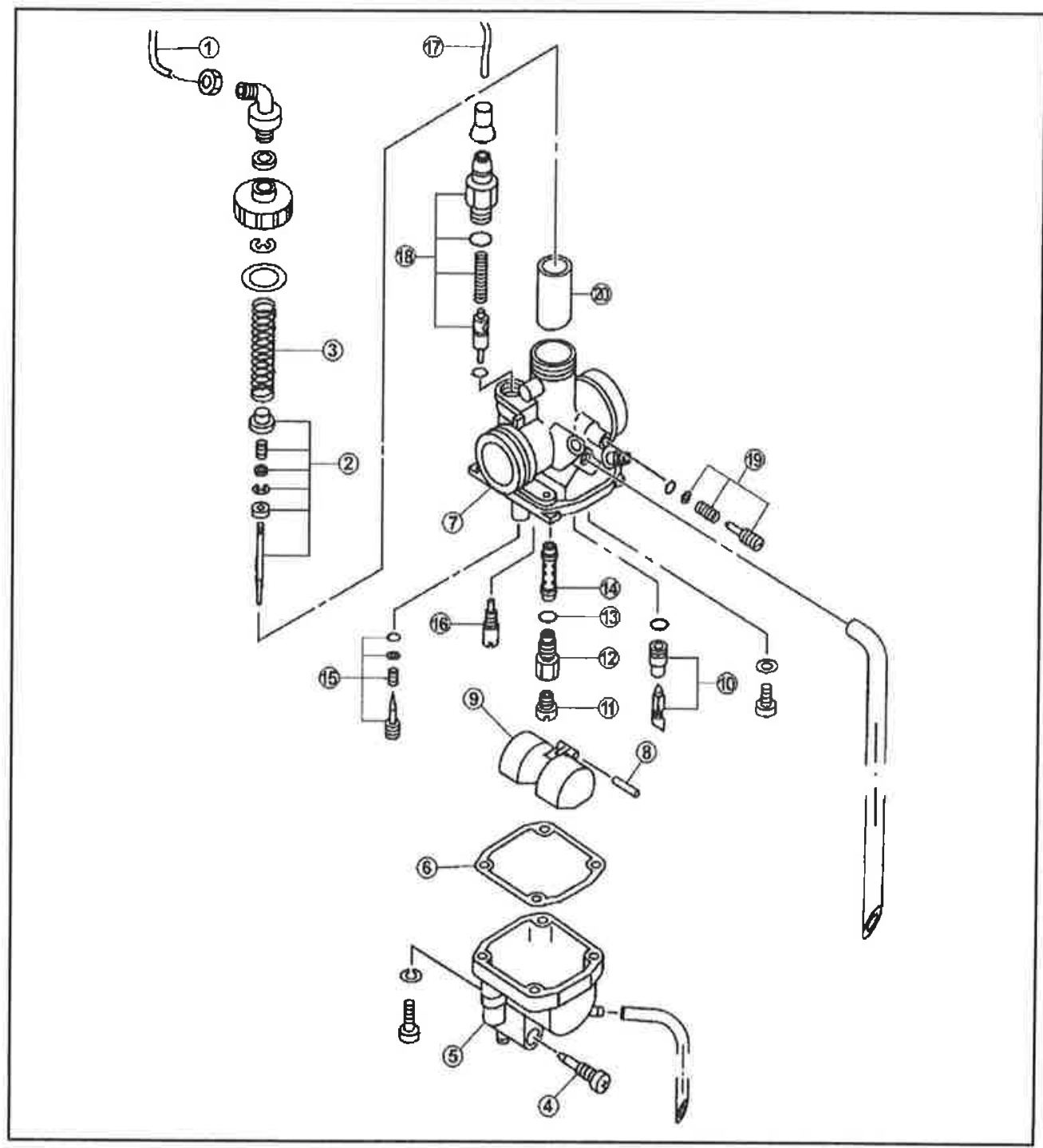

Figura 9: Vista explodida do carburador (PUBLICAÇÃO YAMAHA, 2000).

Legenda:

1. Cabo do acelerador

2. Conjunto agulha do pistonete

3. Mola do pistonete

4. Parafuso de dreno

5. Cuba do carburador

6. Junta da cuba

7. Corpo do carburador

8. Pino da bóia

9. Bóia da cuba
10. Conjunto da válvula de agulha

11. Giclê de alta carga

12. Difusor 1

13. Anel de borracha do difusor

14. Difusor 2

15. Parafuso de mistura ar e combustivel

16. Giclê de baixa carga

17. Cabo do afogador

18. Conjunto do afogador

19. Parafuso da marcha lenta

20. Pistonete

O motor dispõe de um único par cilindro e pistão (monocilíndrico), conforme mostra a Figura 8. O sistema de acionamento das válvulas é do tipo SOHC (Single Overhead Camshaft), sendo que há somente uma válvula de admissão e outra de escape; ambas são reguladas por uma porca localizada no balancim. O motor é do tipo 
quadrado, ou seja, o curso do cilindro e o diâmetro do pistão têm a mesma medida (54 mm). A razão (ou taxa) de compressão é de 10:1.

Embora o modelo atual esteja enquadrado na transição das fases II e III do programa de emissão de poluentes PROMOT, o estudo levou em consideração a fase I para que os gases poluentes pudessem ser analisados sem a interferência de catalisadores e sistemas de indução de ar que têm a finalidade de reduzir a emissão dos gases poluentes.

Os três motores testados são combinações de dois motores em linha de produção, isto é, o sistema de propulsão pertence a um modelo $125 \mathrm{cc}$ para utilização fora de estrada, enquanto que o sistema de alimentação e escape são de motocicletas para utilização urbana, e não caracteriza um arranjo comercial.

\subsection{Verificações na montagem dos motores}

Após a montagem do motor, utilizando juntas novas nas tampas laterais, no cilindro e cabeçote bem como junta líquida entre as carcaças, é verificado e certificado que todas as medidas estão dentro das especificações do fabricante.

Na montagem verifica-se a vedação da base das válvulas de admissão e escape, ponto do motor, folga das válvulas, altura da bóia da cuba do carburador e compressão do motor.

A vedação da sede da válvula de admissão e escape deve ser verificada com o cabeçote na posição horizontal e preenchimento das câmaras de admissão e de escape com gasolina, conforme mostra a Figura 10.

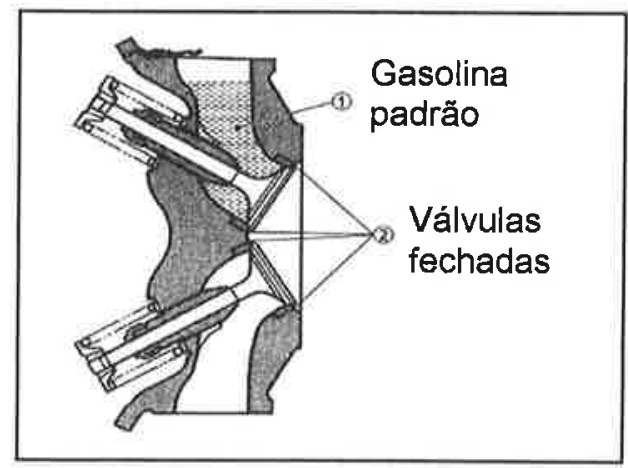

Fig. 10: Vedação das válvulas (PUBLICAÇÃO YAMAHA, 2000). 
Concluído o ajuste do ponto de ignição do motor, o próximo passo é ajustar as folgas das válvulas de admissão e escape. Essa etapa deve ser realizada com o motor frio, conforme o manual de serviço do modelo.

Antes de realizar a medição da pressão de compressão do motor, foi verificada a altura da cuba do carburador com o motor fixado na base do dinamômetro.

Após o amaciamento, utilizando a mesma vela de ignição para os três motores, é instalada uma vela de ignição nova para cada motor e verificada a folga do eletrodo. No final de cada ciclo de durabilidade, deve-se verificar a coloração e o desgaste dos eletrodos da vela de ignição.

A última etapa das medições é a verificação da compressão do motor que deve ser refeita após o amaciamento e no final de cada ciclo no dinamômetro de bancada. Após um rápido aquecimento por um período de 5 minutos e a limpeza da região da vela de ignição com ar comprimido, é instalado o manômetro medidor de compressão (1) na rosca da vela, conforme mostra a Figura 11. Com o acelerador todo acionado, o motor é posto em funcionamento com o auxílio do motor ou pedal de partida até que a pressão se estabilize para a realização da medição.

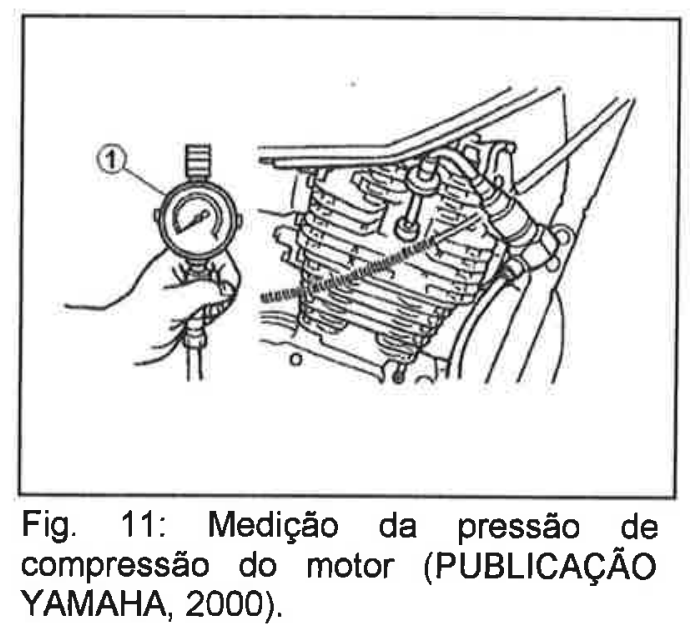

\subsection{Definição da mistura Gasolina C com AEHC}

Segundo os relatórios mensais da ANP, a adição do AEHC na gasolina $C$ é uma das práticas de adulteração mais comuns. Nesse estudo teremos a gasolina padrão com $25 \%$ de AEAC e mais a adição de $15 \%$ de AEHC (E40).

A opção pela adição de $15 \%$ de AEHC leva em conta que essa quantidade não prejudica momentaneamente 0 desempenho do veículo. A marcha lenta fica estável utilizando E40 com o carburador especificado para Gasolina C (E25), porém a 
rotação que deveria ser de $1.400+/-100$ rpm, fica entre $1.000+/-100$ rpm com o motor aquecido. Há mais dificuldade ao dar a partida a frio se comparado com a Gasolina C, mas não a ponto do motor não funcionar.

Para adicionar AEHC na Gasolina $C$, foi feita uma mistura de AEAC com água destilada com a maior quantidade permitida na especificação do AEHC, que é de $7,4 \%$ de água destilada em massa conforme a resolução ANP $n^{\circ} .36$ de 06 de dezembro de 2005.

\subsection{Definição da mistura Gasolina C e o solvente C-9}

A segunda maneira mais usual na adulteração da gasolina $C$ está na adição de solvente. Neste estudo foi selecionado o solvente Best Solv 9, utilizado na formulação de "thinners" para secagem lenta de tintas e esmaltes sintéticos. Esse solvente também é conhecido como Alquilbenzeno 9 ou solvente C-9. Sua fórmula genérica é $\mathrm{C}_{9} \mathrm{H}_{12}$ e trata-se de uma mistura complexa de hidrocarbonetos aromáticos. $\mathrm{A}$ composição típica em porcentagem em massa é de: $38,6 \%$ de etil - tolueno, $36,6 \%$ de tri - metil - benzeno, $12,1 \%$ de $n$ - propil - benzeno, $9,8 \%$ de Indano, $1,7 \%$ de iso propil - benzeno, $0,6 \%$ de dietil - benzeno e $0,6 \%$ de $\mathrm{C} 8$ aromáticos.

Para se definir a quantidade em massa desse solvente a ser adicionado à gasolina $C$, adotou-se o critério de continuar satisfazendo a especificação da Gasolina C estabelecida na resolução ANP n. 309 de 27 de dezembro de 2001.

A mistura obtida será caracterizada pela realização dos seguintes ensaios: cor, aspecto visual, teor de álcool (NBR 13992-97), massa específica a $20^{\circ} \mathrm{C}$ (ASTM D 4052-02e1), destilação (ASTM D 86-07a), corrosão (ASTM D 130-04), enxofre total (ASTM D 4294-03), período de indução, (ASTM D 525-01), pressão de vapor (ASTM D 5191-04a), goma atual (ASTM D 6277-01), benzeno (ASTM D 6277-01) e detalhamento dos porcentuais de aromáticos, olefinas e saturados (DHA-PIANO).

\subsection{Procedimento para a mistura dos combustíveis}

A gasolina padrão, o AEAC e o solvente C-9 foram adquiridos em tambores de 200 litros. A gasolina padrão, mesmo combustível utilizado na homologação de emissões de poluentes de veículos, foi adquirida diretamente da Petrobras, enquanto que o solvente $\mathrm{C}-9$ e o AEAC foram adquiridos por distribuidoras. 
Para a formulação dos combustíveis, são utilizados tambores novos de 20 litros com tampa rosqueada. Os tambores eram revestidos internamente com epóxi fenólico, como os usados para transporte aéreo de combustível.

A gasolina padrão, o AEAC e o solvente $\mathrm{C}-9$ foram fornecidos em tambores de 20 litros.

Outro tambor novo de 20 litros foi adquirido para armazenar as misturas. Após o esvaziamento de cada tambor foi inspecionado o revestimento interno. Caso fossem identificadas alterações no revestimento, o tambor era substituído por um novo.

As misturas dos combustiveis foram preparadas com o auxílio de uma bomba manual de sucção com mangueira, marca Miyake, modelo BD-type, de vazão de 6,5 a $10 \mathrm{l} / \mathrm{min}$, um funil e duas probetas graduadas, uma de 2.000 mililitros e outra de 200 mililitros.

Preferencialmente, as misturas eram preparadas no dia do consumo com o objetivo de evitar que fenômenos como a oxidação pudessem interferir nos resultados dos ensaios.

Depois de concluída a formulação da mistura, ela era armazenada por pelo menos trinta minutos antes do abastecimento do reservatório de 16 litros em aço com tratamento superficial em zinco.

A extensão do funil na preparação, colocado no bocal do tambor de mistura, era o indicador que a quantidade de combustivel estava correta no tambor de 20 litros.

A formulação da gasolina E25 foi realizada a partir de 12 litros de gasolina padrão e 4 litros de AEAC. Para a formulação da gasolina adulterada com solvente, foram misturados 3,2 litros de $\mathrm{C}-9,8,8$ litros de gasolina padrão e 4 litros de AEAC. $\mathrm{Na}$ formulação da gasolina E40 foram utilizados 9,6 litros de gasolina padrão, 6,232 litros de AEAC e 0,168 litro de água destilada.

A água destilada utilizada no combustível E40 refere-se a $7 \%$ em volume somente dos $15 \%$ da mistura do AEAC. Dessa forma, tratava-se de uma mistura de $25 \%$ de AEAC com $15 \%$ de AEHC formulado.

\subsection{Ensaios no dinamômetro de bancada}

Para avaliar a durabilidade dos motores em dinamômetro de bancada, calculou-se o número de horas que uma motocicleta demoraria para percorrer uma distância de 3.000 quilômetros, valor intermediário entre as revisões periódicas 
conforme as orientações do manual do proprietário do modelo. O amaciamento foi realizado considerando um percurso de 478 quilômetros (conforme Tabela 6), metade do valor que consta no manual do proprietário. O ciclo de amaciamento era composto por um período de 60 minutos de funcionamento em marcha lenta, 150 minutos em carga parcial (com metade do acelerador aberto) e 270 minutos com o acelerador aberto em rotações de funcionamento conseguidas com a utilização da quinta marcha.

Considerando que a transmissão primária, entre a engrenagem primária do virabrequim e a campana da embreagem possui engrenagens com, respectivamente, 19 e 68 dentes, tem-se uma relação de transmissão de 3,579:1. O câmbio de cinco marchas possui relações de transmissão de 2,642 para primeira marcha, 1,777 para a segunda marcha, 1,315 para a terceira marcha, 1,045 para a quarta marcha e 0,875 para a quinta marcha. Por último, a transmissão secundária por corrente é composta por um pinhão e uma coroa que possuem, respectivamente, 14 e 43 dentes (relação de 3,071:1). O perímetro da roda é de $1,93 \mathrm{~m}$, a massa do veículo em ordem de marcha (EOM) é de 188 quilogramas e o pneu traseiro é calibrado com uma pressão efetiva de $2,0 \mathrm{kgf} / \mathrm{cm}^{2}$.

Para o cálculo da distância percorrida, utilizou-se as equações 1 e 2:

$$
V=\frac{p \times N \times 60}{1000 \times I} \text { (1) D } \quad V \times t
$$

onde:

- perímetro do pneu $p=1,93 \mathrm{~m}$

- relação total de engrenamento para segunda marcha $12=19,43$

- relação total de engrenamento para terceira marcha $I 3=14,38$

- relação total de engrenamento para quarta marcha $14=11,43$

- relação total de engrenamento para quinta marcha $15=9,56$

- rotação do motor $\mathrm{N}$ em rpm

- velocidade $V$ em quilômetros por hora $(\mathrm{km} / \mathrm{h})$

- distância percorrida $D$ em quilômetros

- intervalo de tempo t em horas

Dessa maneira, a distância percorrida associada ao amaciamento, em função das rotações e dos engrenamentos utilizados estão relacionadas na Tabela 6. 
A execução do amaciamento deve acontecer no mesmo período para os três motores, cumprindo o protocolo estabelecido na Tabela 6. A vela de ignição, o conjunto caixa filtro de ar, o escapamento e o carburador são os mesmos utilizados em todo o amaciamento.

As temperaturas do óleo no cárter e na base da vela da ignição foram monitoradas em todo ciclo para que os motores tivessem o mesmo padrão de amaciamento.

Tabela 6. Amaciamento dos três motores com gasolina E25.

\begin{tabular}{|c|c|c|c|c|c|c|}
\hline Marcha & Condção & RPM do motor & $\begin{array}{c}\text { Relação de } \\
\text { transmissăo (i) }\end{array}$ & $\begin{array}{c}\text { Velocidade da } \\
\text { Motocicleta }(\mathrm{Km} / \mathrm{h})\end{array}$ & $\begin{array}{l}\text { Duração } \\
\text { (horas) }\end{array}$ & Quilometragem \\
\hline \multicolumn{7}{|c|}{ MANTER EM MARCHA LENTA DURANTE 1 HORA } \\
\hline $5^{a}$ & $1 / 2$ acelerador aberto & 4.000 & 9,56 & 48,44 & 0,5 & 24,22 \\
\hline $5^{\mathrm{a}}$ & $1 / 2$ acelerador aberto & 4.500 & 9,56 & 54,49 & 0,5 & 27,25 \\
\hline $5^{a}$ & $1 / 2$ acelerador aberto & 5.000 & 9,56 & 60,55 & 0,5 & 30,27 \\
\hline $5^{a}$ & $1 / 2$ acelerador aberto & 5.500 & 9,56 & 66,60 & 0,5 & 33,30 \\
\hline $5^{a}$ & $1 / 2$ acelerador aberto & 6.000 & 9,56 & 72,66 & 0,5 & 36,33 \\
\hline $5^{a}$ & Acelerador aberto & 4.000 & 9,56 & 48,44 & 0,5 & 24,22 \\
\hline $5^{a}$ & Acelerador aberto & 4.500 & 8,56 & 54,49 & 0,5 & 27,25 \\
\hline $5^{a}$ & Acelerador aberto & 5.000 & 9,56 & 60,55 & 0,5 & 30,27 \\
\hline $5^{a}$ & Acelerador aberto & 5.500 & 9,56 & 66,60 & 0,5 & 33,30 \\
\hline $5^{a}$ & Acelerador aberto & 6.000 & 9,56 & 72,66 & 0,5 & 36,33 \\
\hline $5^{a}$ & Acelerador aberto & 6.500 & 9,56 & 78,71 & 0,5 & 39,36 \\
\hline $5^{a}$ & Acelerador aberto & 7.000 & 9,56 & $84, \pi$ & 0,5 & 42,38 \\
\hline $5^{a}$ & Acelerador aberto & 7.500 & 9,56 & 90,82 & 0,5 & 45,41 \\
\hline \multirow[t]{2}{*}{$5^{a}$} & Acelerador aberto & 8.000 & 9,56 & 96,88 & 0,5 & 48,44 \\
\hline & & & & $\begin{array}{c}\text { Total } \\
\text { Amaciamento } \\
\end{array}$ & 7,00 & 478,34 \\
\hline
\end{tabular}

O teste de durabilidade foi feito em três ciclos de 36 horas cada, totalizando 108 horas. Cada motor funciona com seu respectivo combustível, isto é, Gasolina C (E25), gasolina adulterada com a adição de solvente (C-9); e por último a gasolina adulterada com a adição de AEHC (E40).

Dessa maneira, a distância total percorrida durante os testes de durabilidade de cada motor é mostrada na Tabela 7.

Antes de iniciar cada ciclo dos motores, era feita uma revisão periódica. Esta revisão engloba a verificação do ponto de ignição do motor, a folga de válvulas, as condições do filtro de ar, a folga do eletrodo da vela de ignição, o nível de combustível na cuba do carburador, a compressão do motor e o consumo total de óleo lubrificante, incluindo a quantidade encontrada na caixa do filtro de ar.

Cada ciclo do ensaio de durabilidade foi realizado no período de 4 dias (aproximadamente nove horas por dia).

As revisões e o levantamento das curvas de potência foram feitas no último dia da semana. 
Tabela 7. Durabilidade dos três motores com os respectivos combustiveis.

\begin{tabular}{|c|c|c|c|c|c|c|}
\hline Marcha & Condição & RPM do motor & $\begin{array}{c}\text { Relação de } \\
\text { tansmissão (i) }\end{array}$ & $\begin{array}{c}\text { Velocidade da } \\
\text { Motocicleta }\end{array}$ & $\begin{array}{c}\text { Duração } \\
\text { (horas) }\end{array}$ & Quilometragem \\
\hline $2^{a}$ & Torque máximo & 6.500 & 19,43 & 38,74 & 1,5 & 58,11 \\
\hline $3^{a}$ & Torque máximo & 6.500 & 14,38 & 52,34 & 6 & 314,07 \\
\hline $4^{\mathrm{a}}$ & Torque máximo & 6.500 & 11,43 & 65,88 & 5 & 329,40 \\
\hline $4^{a}$ & Potência máxima & 8.500 & 11,43 & 86,15 & 5 & 430,75 \\
\hline $5^{a}$ & Potência máxima & 8.500 & 9,56 & 102,93 & 7 & 720,53 \\
\hline $5^{a}$ & Velocidade máxima & 8.107 & 9,56 & 98,17 & 10 & 981,74 \\
\hline $5^{a}$ & Super rotação & 9.350 & 9,56 & 113,23 & 1,5 & 169,84 \\
\hline & & & & $\begin{array}{c}\text { Sub-total } \\
\text { Durabilidade }\end{array}$ & 36,00 & $3.004,45$ \\
\hline \multicolumn{7}{|l|}{$2^{\circ} \mathrm{CICLO}$} \\
\hline Marcha & Condição & RPM do motor & $\begin{array}{l}\text { Relaçāo de } \\
\text { transmissão (i) }\end{array}$ & $\begin{array}{c}\text { Velocidade da } \\
\text { Motocicleta }\end{array}$ & $\begin{array}{l}\text { Duraçāo } \\
\text { (horas) }\end{array}$ & Quilometragem \\
\hline $2^{a}$ & Torque máximo & 6.500 & 19,43 & 38,74 & 1,5 & 58,11 \\
\hline $3^{a}$ & Torque máximo & 6.500 & 14,38 & 52,34 & 6 & 314,07 \\
\hline $4^{\mathrm{a}}$ & Torque máximo & 6.500 & 11,43 & 65,88 & 5 & 329,40 \\
\hline $4^{\mathrm{a}}$ & Potência máxima & 8.500 & 11,43 & 86,15 & 5 & 430,75 \\
\hline $5^{a}$ & Potência máxima & 8.500 & 9,56 & 102,93 & 7 & 720,53 \\
\hline $5^{a}$ & Velocidade máxima & 8.107 & 9,56 & 98,17 & 10 & 981,74 \\
\hline $5^{\mathrm{a}}$ & Super rotaçăo & 9.350 & 9,56 & 113.23 & 1,5 & 169,84 \\
\hline & & & & $\begin{array}{c}\text { Sub-total } \\
\text { Durabilidade }\end{array}$ & 36,00 & $3.004,45$ \\
\hline \multicolumn{7}{|l|}{$3^{\circ} \mathrm{CICLO}$} \\
\hline Marcha & Condição & RPM do motor & $\begin{array}{c}\text { Relação de } \\
\text { transmissão (i) }\end{array}$ & $\begin{array}{l}\text { Velocidade da } \\
\text { Motocicleta }\end{array}$ & $\begin{array}{c}\text { Duraçăo } \\
\text { (horas) }\end{array}$ & Quilometragem \\
\hline $2^{a}$ & Torque máximo & 6.500 & 19,43 & 38,74 & 1,5 & 58,11 \\
\hline $3^{a}$ & Torque máximo & 6.500 & 14,38 & 52,34 & 6 & 314,07 \\
\hline $4^{a}$ & Torque máximo & 6.500 & 11,43 & 65,88 & 5 & 329,40 \\
\hline $4^{a}$ & Potência máxima & 8.500 & 11,43 & 86,15 & 5 & 430,75 \\
\hline $5^{a}$ & Potência máxima & 8.500 & 9,56 & 102,93 & 7 & 720,53 \\
\hline $5^{a}$ & Velocidade máxima & 8.107 & 9,56 & 98,17 & 10 & 981,74 \\
\hline \multirow[t]{3}{*}{$5^{a}$} & Super rotação & 9.350 & 9,56 & 113,23 & 1,5 & 169,84 \\
\hline & & & & $\begin{array}{c}\text { Sub-total } \\
\text { Durabilidade }\end{array}$ & 36,00 & $3.004,45$ \\
\hline & & & & $\begin{array}{c}\text { Total } \\
\text { Durabilidade } \\
\end{array}$ & 108,00 & $9.013,35$ \\
\hline
\end{tabular}

3.8 Acompanhamento do óleo lubrificante

O experimento incorpora o monitoramento do óleo lubrificante do motor em toda sua extensão. Para tanto, uma caixa com 24 frascos de um litro de óleo de quatro tempos da marca Yamalube 20W50, API SL, JASO MA, datada de 22/06/2007, foi separada para todo o experimento (código do óleo 90793-AB401 e código da caixa 50931).

Após o amaciamento do motor, na primeira troca de óleo, foram adicionados 890 gramas de óleo no cárter de cada um dos motores. Na fase final do amaciamento e nos três ciclos do ensaio de durabilidade, foram coletadas dez amostras para cada motor. 
Em cada ciclo foram retiradas amostras em frascos de 100 mililitros para os primeiros quinze minutos, após dezoito horas e finalmente com trinta e seis horas. As coletas intermediárias e a final foram feitas com, no mínimo, $60^{\circ} \mathrm{C}$ de temperatura do óleo no cárter.

Nessas condições, efetuam-se medições gerais nos primeiros minutos de funcionamento, na metade e no final dos blocos de 36 horas. Dessa forma pretende-se avaliar o desgaste de cada motor ao longo de cada ciclo da durabilidade com os combustiveis determinados para cada teste.

Cada ciclo de 36 horas equivale a um percurso de três mil quilômetros. Essa quilometragem representa o período da troca do óleo lubrificante do motor. Para verificar os desgastes do óleo e do motor ao longo do ciclo, foi definida a realização da medição do óleo novo, do óleo após dez minutos, dezoito horas e 36 horas.

Após o término de cada ciclo, o óleo foi trocado e foram adicionados novamente 890 gramas no cárter. A troca do óleo lubrificante é feita após aquecer o óleo do cárter a temperatura de $60^{\circ} \mathrm{C}$. O escoamento do óleo tem a duração de trinta minutos. Após esse período de tempo, o parafuso de dreno do cárter foi instalado.

Cada amostra retirada foi pesada e a mesma quantidade em massa é reposta. No período da manhã, antes do motor iniciar a durabilidade, era verificado o nível de óleo. Caso estivesse abaixo do nível máximo, o nível do óleo lubrificante era restabelecido e anotada a quantidade em massa adicionada.

As propriedades do óleo lubrificante analisadas foram:

- índice de viscosidade (D-2270);

- número de basicidade total em miligrama por $\mathrm{KOH} / \mathrm{g}$ (D-2896);

- viscosidade a $40^{\circ} \mathrm{C}(\mathrm{D}-445)$;

- viscosidade a $100^{\circ} \mathrm{C}(\mathrm{D}-445)$;

- viscosidade a $150^{\circ} \mathrm{C}(\mathrm{D}-445)$;

- número de acidez total em miligrama por $\mathrm{KOH} / \mathrm{g}$ (D-664);

- porcentagem em massa de água (D-95);

- oxidação, nitração e presença de sulfatos em Abs/cm (IT-BTC-110M);

- porcentagem de gasolina e álcool CG (D-3525), e

- análise espectrométrica - EEO em ppm de alumínio, cobre, ferro, silício e zinco. 


\subsection{Procedimento para a coleta do óleo lubrificante}

O motor devia estar com, no mínimo, $60^{\circ} \mathrm{C}$ de temperatura do óleo lubrificante no cárter para certificar que o óleo estivesse homogeneizado.

Para a coleta era necessária uma bomba manual de sucção de marca Catterpilar e uma mangueira nova descartável, ambas sem a presença de qualquer contaminantes e seca interna e externamente.

A mangueira devia ter uma medida aproximadamente de trinta centímetros e um frasco especial para coleta de amostras.

O frasco é constituído por um batoque (tampa bolha), uma tampa com rosca e um recipiente de 150 mililitros novo, sem a presença de contaminantes e descartável.

Antes da coleta era necessária uma limpeza externa na região próxima ao medidor do nível de óleo, local que é retirada a amostra para a análise em laboratório.

Coletava-se cem mililitros de óleo e a massa do recipiente era medida. Em seguida, era reposta a mesma quantidade de óleo de mesma especificação e lote de produção.

Buscou-se evitar o contato da mangueira de coleta com a carcaça interna e externa do compartimento.

Logo após a retirada, o recipiente com o batoque e tampa era fechado e identificado com os dados do motor e o número de horas de trabalho.

3.10 Levantamento das curvas de potência e torque, consumo e emissão de poluentes

Após o amaciamento foram levantadas três curvas de potência e torque, bem como medições de gases $\mathrm{CO}_{2}, \mathrm{CO}$ e $\mathrm{HC}$ de escapamento para cada motor com Gasolina C, totalizando nove curvas. As curvas foram levantadas na quinta marcha, com o acelerador totalmente aberto, com início a $9.000 \mathrm{rpm}$ e término a $3.500 \mathrm{rpm}$ e com discretização de 500 rpm entre cada medição. O óleo era mantido com, no mínimo, $60^{\circ} \mathrm{C}$ durante a medição.

Uma análise estatística foi empregada sobre o conjunto de resultados dos nove ensaios. Foram obtidas as médias, os desvios-padrão e as incerteza com nível de confiança de $95 \%$ a cada 500 rpm usando a distribuição t de Student. 
Com a verificação que os resultados encontravam-se entre os limites mínimo e máximo das curvas de potência, torque e concentrações dos gases $\mathrm{CO}_{2}, \mathrm{CO}$ e $\mathrm{HC}$, iniciou-se o primeiro ciclo do teste de durabilidade de cada motor.

Os valores das curvas de potência e torque são apresentados neste trabalho em porcentagens devido ao contrato de sigilo das informações firmado com a empresa patrocinadora e principal beneficiada desse experimento.

O levantamento da curva de potência foi feito conforme a orientação da norma NBR 1585.

Antes de iniciar as mediçōes, verificou-se:

- o ponto estático de ignição do motor entre o magneto e a engrenagem do cabeçote,

- a folga de 0,6 a 0,7 milímetros entre os eletrodos da vela de ignição,

- a medida das folgas de válvulas entre 0,08 a 0,12 milímetros para admissão e entre 0,10 a 0,14 milímetros para escape,

- o nível do óleo do motor por meio da vareta de medição,

- a posição da bóia de combustível entre 6 a 7 milímetros,

- acelerador completamente acionado e quinta marcha engrenada.

No ambiente da sala mediu-se a temperatura, a umidade e a pressão atmosférica. Além disso, fez-se o monitoramento da temperatura do motor na base da vela de ignição, no parafuso de dreno de óleo e na entrada da caixa do filtro de ar. A rotação do motor foi medida por tacômetro digital conectado no cabo da vela de ignição.

A medição dos gases de escape segue a mesma seleção dos gases da inspeção veicular pela lei municipal de São Paulo 14.717 e decreto número 49.463 .

\subsection{Análise estatística usando a distribuição t de Student}

A partir de três (quantidade mínima necessária para realizar a análise estatística) levantamentos de curvas de desempenho para cada motor, foram calculadas para cada ente de interesse:

- a média aritmética 3 :

$$
\bar{x}=\frac{1}{n} \cdot(x 1+x 2+x n)
$$


Onde: $\quad \bar{X}=$ média aritmética

$\mathrm{n}=$ número de amostras

$\mathrm{x}=$ valor medido

- o desvio padrão 4:

$$
\sigma=\sqrt{\left[\frac{1}{n} \cdot \sum_{i=1}^{n}(x i-\bar{X})^{2}\right]}
$$

Onde: $\quad \sigma=$ desvio padrão

$\overline{\mathrm{X}}=$ média aritmética

$\mathrm{n}=$ número de amostras

$x i=$ valor medido

- a incerteza 5 :

$$
E=\sigma \cdot \operatorname{ta/2} \cdot \frac{1}{\sqrt{n}}
$$

Onde:

$$
\begin{aligned}
& E=\text { incerteza } \\
& n=\text { número de amostras } \\
& t \alpha_{/ 2}=\text { valor obtido para a distribuição } t \text { de Student com grau de }
\end{aligned}
$$
liberdade $(n-1)$ e grau de confiança de $95 \%$

Dessa maneira, o intervalo de confiança $\mu$ apresenta-se da seguinte maneira,

$$
\bar{X}-E<\mu<\bar{X}+E
$$

Onde: $\quad \bar{X}=$ média aritmética

$$
\begin{aligned}
& \bar{X}-E=\text { valor mínimo } \\
& \bar{X}+E=\text { valor máximo }
\end{aligned}
$$

3.12 Equipamentos utilizados na medição da curva de potência e torque, consumo específico e emissão de gases poluentes

Para o levantamento da curva de potência, utilizou-se o dinamômetro de bancada AVL $40 \mathrm{~kW}$. Para a medição de consumo de combustível foi utilizada a 
balança AVL, modelo APU $116 \mathrm{H} \mathrm{e}$, para medir as concentrações dos gases $\mathrm{CO}_{2}$, $\mathrm{CO}$ e HC no escapamento, utilizou-se o Mexa 1300 de marca TCA Horiba.

Durante o início da medição dos gases, calibra-se o equipamento Mexa 1300 para comparação adequada com os gases padrões. O Mexa 1300 utiliza bancos ópticos do método chamado de Infravermelho não dispersivo (non-dispersive infrared detector" - NDIR) para medir a concentração $\mathrm{HC}, \mathrm{CO}$ e $\mathrm{CO}_{2}$ presentes nos gases de escape coletados.

Conforme o manual de utilização do Mexa 1300, para as determinações das concentrações de $\mathrm{C}_{3} \mathrm{H}_{8}$, CO e $\mathrm{CO}_{2}$, os filtros devem ser verificados periodicamente. $\mathrm{O}$ filtro coletor de óleo e o filtro de particulado devem ser verificados quanto à fixação, à vedação e ao estado de conservação.

Antes e após as medições deve-se limpar a tubulação de medição com ar comprimido, conhecido como "purge", devido aos resíduos gerados na combustão como água, óleo e hidrocarbonetos. A drenagem manual da tubulação e do Mexa 1300 deve ser verificado também periodicamente devido ao acúmulo de água. Após a drenagem, a válvula de esfera deve estar completamente fechada para evitar que vazamentos comprometam a exatidão da medição. 


\section{RESULTADOS OBTIDOS E ANÁLISE}

Os resultados obtidos são apresentados seguindo a ordem cronológica do experimento. Resultados em maiores detalhes encontram-se disponibilizados nos Apêndices $A, B, C$ e $D$, e no Anexo $A$.

\subsection{Análise química das misturas realizadas}

O primeiro passo consistiu na realização das análises químicas dos três combustíveis, formulados de acordo com a metodologia proposta.

Os resultados das análises de caracterização físico-química desses combustíveis, realizadas pelo Laboratório de Combustíveis e Lubrificantes do IPT-SP, estão relacionados na Tabela 8, abaixo.

Tabela 8: Mistura dos combustíveis testados

\begin{tabular}{|c|c|c|c|c|}
\hline Característica & Unidade & E25 & $C-9$ & E40 \\
\hline Cor & \multirow{2}{*}{ não tem } & \multirow{2}{*}{$\begin{array}{l}\text { Amarelo, limpedoe } \\
\text { isento de impurezas }\end{array}$} & \multirow{2}{*}{$\begin{array}{l}\text { Amare b, limpedoe } \\
\text { isento de impurezas }\end{array}$} & \multirow{2}{*}{$\begin{array}{l}\text { Amareb, Ilmpedo e } \\
\text { isento de impurezas }\end{array}$} \\
\hline Aspecto & & & & \\
\hline $\begin{array}{l}\text { Álcool Etílico Anidro } \\
\text { Combustível (AEAC) }\end{array}$ & $\%$ em volume & $26 \pm 1$ & $26 \pm 1$ & $41 \pm 1$ \\
\hline $\begin{array}{l}\text { Massa específica a } \\
20^{\circ} \mathrm{C}\end{array}$ & $\mathrm{Kg} / \mathrm{m}^{3}$ & $748,3 \pm 0,1$ & $767,4 \pm 0,1$ & $759,4 \pm 0,1$ \\
\hline \multicolumn{5}{|l|}{ Destilação } \\
\hline $10 \%$ evaporado, máx. & & $58 \pm 2$ & $61 \pm 2$ & $58 \pm 2$ \\
\hline $50 \%$ evaporado, máx. & ${ }^{\circ} \mathrm{C}$ & $75 \pm 1$ & $77 \pm 1$ & $75 \pm 1$ \\
\hline $90 \%$ evaporado. & $\tau$ & $166 \pm 3$ & $166 \pm 3$ & $161 \pm 3$ \\
\hline PFE, máx. & & $195 \pm 3$ & $189 \pm 3$ & $193 \pm 3$ \\
\hline Residuo & $\%$ em volume & 0,8 & 1,1 & 0,9 \\
\hline $\begin{array}{l}N^{\circ} \text { de Octano Motor - } \\
\text { MON }\end{array}$ & não tem & 84,60 & 86,10 & 86,20 \\
\hline $\begin{array}{l}N^{0} \text { de Octano Pesquisa. } \\
\text { RON }\end{array}$ & não tem & 96,90 & 98,40 & 98,20 \\
\hline $\begin{array}{l}\text { Indice Antidetonante - } \\
\text { IAD, mín. }\end{array}$ & não tem & 90,75 & 92,25 & 92,20 \\
\hline $\begin{array}{l}\text { Pressão de vapor a } \\
37,8^{\circ} \mathrm{C}\end{array}$ & $\mathrm{kPa}$ & $55,4 \pm 0,4$ & $49,6 \pm 0,4$ & $55,2 \pm 0,4$ \\
\hline $\begin{array}{l}\text { Goma atual lavada } \\
\text { máx. }\end{array}$ & $\mathrm{mg} / 100 \mathrm{ml}$ & $2,0 \pm 0,4$ & $1,5 \pm 0,4$ & $2,0 \pm 0,4$ \\
\hline $\begin{array}{l}\text { Período de indução a } \\
100^{\circ} \mathrm{C} \text {, mín. }\end{array}$ & minutos & 2530 & 4752 & 1492 \\
\hline $\begin{array}{l}\text { Corrosidade ao cobre a } \\
50^{\circ} \mathrm{C}, 3 \mathrm{~h} \text {, máx. }\end{array}$ & não tem & $1 a$ & $1 \mathrm{a}$ & $1 a$ \\
\hline Enxofre, máx. & $\%$ em massa & 0,020 & 0,015 & 0,015 \\
\hline Benzeno, máx. & $\%$ em vol ume & $0,2 \pm 0,1$ & $0,3 \pm 0,1$ & $0,3 \pm 0,1$ \\
\hline
\end{tabular}


Observa-se que os combustíveis padrão e adulterados atendem, em sua maioria, as mesmas especificações. Apesar da mistura denominada E40 ser facilmente identificada pelo teor alcoólico, a mistura C-9 só será identificada no caso de apresentar o marcador no solvente.

A especificação da gasolina comum tipo C conforme a Portaria ANP $n^{\circ} .309$ de 27/12/2001 permite uma porcentagem máxima de hidrocarbonetos em $45 \%$ de aromáticos e $30 \%$ de olefínicos. A análise cromatográfica em fase gasosa da mistura C-9, detalhada na Tabela 9 abaixo, mostra o respeito a essa especificação.

Tabela 9: Dados da cromatografia em fase gasosa da mistura C-9.

\begin{tabular}{|c|c|c|c|c|c|c|c|c|c|c|}
\hline \multirow{3}{*}{$\begin{array}{l}\text { Número de } \\
\text { carbonos }\end{array}$} & \multicolumn{10}{|c|}{ Tipos de Hidrocarbonetos } \\
\hline & \multicolumn{2}{|c|}{$\begin{array}{c}\text { Parafinicos } \\
(\%)\end{array}$} & \multicolumn{2}{|c|}{$\begin{array}{c}\text { Isoparafínicos } \\
(\%)\end{array}$} & \multicolumn{2}{|c|}{$\begin{array}{c}\text { Aromáticos } \\
(\%)\end{array}$} & \multicolumn{2}{|c|}{$\begin{array}{c}\text { Naftênicos } \\
(\%)\end{array}$} & \multicolumn{2}{|c|}{$\begin{array}{c}\text { Olefinicos } \\
(\%)\end{array}$} \\
\hline & $\begin{array}{l}\text { Combustlvel } \\
\text { referencia }\end{array}$ & C-9 & $\begin{array}{c}\text { Combustivel } \\
\text { referéncia }\end{array}$ & C-9 & $\begin{array}{c}\text { Combustlvel } \\
\text { referencie }\end{array}$ & C-9 & $\begin{array}{l}\text { Combustivel } \\
\text { referencla }\end{array}$ & C-9 & $\begin{array}{l}\text { Combustivel } \\
\text { referencia }\end{array}$ & C-9 \\
\hline $\mathrm{C4}$ & - & 0,67 & 0,32 & 0,09 & - & - & - & - & 0,95 & 0,40 \\
\hline C5 & 1,34 & 4,30 & 4,73 & 5,70 & - & - & - & - & 5,15 & 2,95 \\
\hline $\mathrm{C} 6$ & 2,37 & 1,59 & 4,03 & 3,33 & 0,36 & 0,17 & 2,10 & 0,80 & 4,52 & 2,27 \\
\hline $\mathrm{C7}$ & 1,88 & 0,59 & 3,30 & 1,56 & 4,58 & 2,83 & 2,40 & 0,78 & 2,12 & 5,14 \\
\hline $\mathrm{C8}$ & 1,73 & 0,45 & 3,80 & 3,94 & 4,96 & 2,24 & 3,00 & 1,44 & 0,64 & 0,29 \\
\hline $\mathrm{Cg}$ & 1,07 & 0,87 & 2,46 & 1,91 & 2,26 & 11,83 & 0,36 & 0,99 & 0,15 & 0,16 \\
\hline C10 & 0,81 & 0,78 & 1,57 & 6,66 & 5,58 & 5,78 & - & 0,35 & - & - \\
\hline C11 & 0,59 & 0,39 & - & - & 0,53 & 0,27 & - & - & - & - \\
\hline C12 & 0,39 & 0,08 & - & - & 0,32 & 0,15 & - & - & - & - \\
\hline C13 & 0,07 & 0,02 & - & - & - & - & - & - & - & - \\
\hline Total & 10,3 & 9,7 & 20,2 & 23,2 & 18,6 & 23,3 & 7,9 & 4,4 & 13,5 & 11,2 \\
\hline
\end{tabular}

Ou seja, mesmo com a adição de $20 \%$ do solvente C-9 pode-se comprovar nessa análise que o volume máximo de hidrocarbonetos aromáticos é de $23,3 \%$ e o de olefínicos é $11,2 \%$, consideravelmente abaixo do volume máximo permitido segundo as especificações da Gasolina C.

Verifica-se, entretanto, que os aromáticos de nove carbonos têm, na mistura contendo C-9, uma porcentagem superior ao combustível de referência.

\subsection{Amaciamento dos motores}

No amaciamento dos motores, todos utilizando combustível E25, não foi observado qualquer problema quanto ao funcionamento, nível de óleo e vazamentos nos motores. $O$ procedimento de amaciamento no dinamômetro de bancada foi seguido corretamente, com controle da temperatura de óleo e base da vela de ignição, de acordo com a metodologia proposta. Os resultados obtidos estão no Apêndice C. 
4.3 Normalização dos motores

Após o amaciamento com o combustível E25, foram realizados os levantamentos das curvas de desempenho (potência, torque e consumo específico) dos três motores.

Para comprovar que os três motores partiriam com as mesmas especificações do carburador e de desempenho de motor no teste de durabilidade com diferentes combustíveis, foi feita uma análise estatística dos dados obtidos, como mostrado abaixo.

Tabela 10: Potência dos motores em porcentagem.

\begin{tabular}{|c|c|c|c|c|c|c|c|c|c|}
\hline \multirow[b]{2}{*}{ RPM } & \multicolumn{3}{|c|}{ Motor 1 (E25) } & \multicolumn{3}{|c|}{ Motor 2 (E25) } & \multicolumn{3}{|c|}{ Motor 3 (E25) } \\
\hline & $\begin{array}{l}\text { Motor } 1 \\
\text { Teste } 1\end{array}$ & $\begin{array}{l}\text { Motor } 1 \\
\text { Teste } 2\end{array}$ & $\begin{array}{l}\text { Motor } 1 \\
\text { Teste } 3\end{array}$ & $\begin{array}{l}\text { Motor } 2 \\
\text { Teste } 1\end{array}$ & $\begin{array}{r}\text { Motor } 2 \\
\text { Teste } 2\end{array}$ & $\begin{array}{l}\text { Motor } 2 \\
\text { Teste } 3\end{array}$ & $\begin{array}{l}\text { Motor } 3 \\
\text { Teste } 1\end{array}$ & $\begin{array}{l}\text { Motor } 3 \\
\text { Teste } 2\end{array}$ & $\begin{array}{l}\text { Motor } 3 \\
\text { Teste } 3\end{array}$ \\
\hline 3500 & $41,7 \%$ & $41,5 \%$ & $42,7 \%$ & $41,4 \%$ & $41,7 \%$ & $41,5 \%$ & $42,4 \%$ & $43,2 \%$ & $43,3 \%$ \\
\hline 4000 & $50,5 \%$ & $50,5 \%$ & $51,4 \%$ & $49,2 \%$ & $49,5 \%$ & $49,5 \%$ & $50,7 \%$ & $52,7 \%$ & $52,6 \%$ \\
\hline 4500 & $58,9 \%$ & $59,4 \%$ & $60,5 \%$ & $59,0 \%$ & $59,0 \%$ & $58,7 \%$ & $59,8 \%$ & $61,1 \%$ & $61,3 \%$ \\
\hline 5000 & $65,8 \%$ & $65,9 \%$ & $68,0 \%$ & $65,2 \%$ & $65,5 \%$ & $66,1 \%$ & $66,9 \%$ & $68,8 \%$ & $68,7 \%$ \\
\hline 5500 & $75,3 \%$ & $75,6 \%$ & $76,0 \%$ & $74,6 \%$ & $75,5 \%$ & $75,3 \%$ & $76,3 \%$ & $77,9 \%$ & $78,1 \%$ \\
\hline 6000 & $82,5 \%$ & $82,6 \%$ & $83,6 \%$ & $83,3 \%$ & $84,0 \%$ & $84,0 \%$ & $85,5 \%$ & $85,4 \%$ & $85,3 \%$ \\
\hline 6500 & $88,5 \%$ & $88,8 \%$ & $89,9 \%$ & $89,6 \%$ & $90,1 \%$ & $90,3 \%$ & $91,5 \%$ & $91,2 \%$ & $91,6 \%$ \\
\hline 7000 & $93,7 \%$ & $93,9 \%$ & $94,4 \%$ & $94,6 \%$ & $95,0 \%$ & $95,0 \%$ & $95,8 \%$ & $96,0 \%$ & $95,9 \%$ \\
\hline 7500 & $97,1 \%$ & $97,5 \%$ & $97,7 \%$ & $98,0 \%$ & $98,2 \%$ & $98,8 \%$ & $98,5 \%$ & $98,8 \%$ & $98,8 \%$ \\
\hline 8000 & $99,4 \%$ & $99,4 \%$ & $100,0 \%$ & $100,0 \%$ & $100,0 \%$ & $100,0 \%$ & $100,0 \%$ & $100,0 \%$ & $100,0 \%$ \\
\hline 8500 & $100,0 \%$ & $100,0 \%$ & $99,8 \%$ & $99,5 \%$ & $99,7 \%$ & $99,7 \%$ & $99,5 \%$ & $99,5 \%$ & $99,7 \%$ \\
\hline 9000 & $98,2 \%$ & $97,5 \%$ & $98,1 \%$ & $99,1 \%$ & $99,1 \%$ & $99,1 \%$ & $98,2 \%$ & $97,4 \%$ & $97,4 \%$ \\
\hline
\end{tabular}

Tabela 11: Análise estatística do levantamento da curva de potência em \%.(usando a distribuição t de Student)

\begin{tabular}{ccccccc}
\hline Rotação & Média & $\begin{array}{c}\text { Desvio } \\
\text { Padrão }\end{array}$ & Conflança & Incerteza & $\begin{array}{c}\text { Valor } \\
\text { mínimo }\end{array}$ & $\begin{array}{c}\text { Valor } \\
\text { máximo }\end{array}$ \\
\hline 3500 & $42,2 \%$ & $0,7 \%$ & $95,0 \%$ & $1,1 \%$ & $41,0 \%$ & $43,3 \%$ \\
\hline 4000 & $50,7 \%$ & $1,3 \%$ & $95,0 \%$ & $2,0 \%$ & $48,8 \%$ & $52,7 \%$ \\
\hline 4500 & $59,8 \%$ & $1,0 \%$ & $95,0 \%$ & $1,6 \%$ & $58,2 \%$ & $61,3 \%$ \\
\hline 5000 & $66,8 \%$ & $1,4 \%$ & $95,0 \%$ & $2,2 \%$ & $64,6 \%$ & $68,9 \%$ \\
\hline 5500 & $76,1 \%$ & $1,2 \%$ & $95,0 \%$ & $1,8 \%$ & $74,2 \%$ & $77,9 \%$ \\
\hline 6000 & $84,0 \%$ & $1,2 \%$ & $95,0 \%$ & $1,8 \%$ & $82,2 \%$ & $85,8 \%$ \\
\hline 6500 & $90,2 \%$ & $1,1 \%$ & $95,0 \%$ & $1,7 \%$ & $88,5 \%$ & $91,9 \%$ \\
\hline 7000 & $94,9 \%$ & $0,8 \%$ & $95,0 \%$ & $1,3 \%$ & $93,6 \%$ & $96,2 \%$ \\
\hline 7500 & $98,1 \%$ & $0,6 \%$ & $95,0 \%$ & $1,0 \%$ & $97,2 \%$ & $99,1 \%$ \\
\hline 8000 & $99,9 \%$ & $0,3 \%$ & $95,0 \%$ & $0,4 \%$ & $99,4 \%$ & $100,3 \%$ \\
\hline 8500 & $99,7 \%$ & $0,2 \%$ & $95,0 \%$ & $0,3 \%$ & $99,4 \%$ & $100,0 \%$ \\
\hline 9000 & $98,2 \%$ & $0,7 \%$ & $95,0 \%$ & $1,1 \%$ & $97,1 \%$ & $99,3 \%$ \\
\hline
\end{tabular}


Para a normalização da curva de torque foram usados os seguintes dados:

Tabela 12: Torque dos motores em porcentagem.

\begin{tabular}{cccccccccc}
\hline \multirow{2}{*}{ RPM } & \multicolumn{3}{c}{ Motor 1 (E25) } & \multicolumn{3}{c}{ Motor 2 (E25) } & \multicolumn{3}{c}{ Motor 3 (E25) } \\
\cline { 2 - 10 } & $\begin{array}{c}\text { Motor 1 } \\
\text { Teste 1 }\end{array}$ & $\begin{array}{c}\text { Motor 1 } \\
\text { Teste 2 }\end{array}$ & $\begin{array}{c}\text { Motor 1 } \\
\text { Teste 3 }\end{array}$ & $\begin{array}{c}\text { Motor 2 } \\
\text { Teste 1 }\end{array}$ & $\begin{array}{c}\text { Motor 2 } \\
\text { Teste 2 }\end{array}$ & $\begin{array}{c}\text { Motor 2 } \\
\text { Teste 3 }\end{array}$ & $\begin{array}{c}\text { Motor 3 } \\
\text { Teste 1 }\end{array}$ & $\begin{array}{c}\text { Motor 3 } \\
\text { Teste 2 }\end{array}$ & $\begin{array}{c}\text { Motor 3 } \\
\text { Teste 3 }\end{array}$ \\
\hline 3500 & $86,7 \%$ & $86,2 \%$ & $87,6 \%$ & $85,3 \%$ & $85,1 \%$ & $84,6 \%$ & $84,9 \%$ & $86,6 \%$ & $86,9 \%$ \\
\hline 4000 & $91,7 \%$ & $91,8 \%$ & $92,2 \%$ & $88,6 \%$ & $88,4 \%$ & $88,3 \%$ & $88,9 \%$ & $92,5 \%$ & $92,5 \%$ \\
\hline 4500 & $95,2 \%$ & $95,9 \%$ & $96,5 \%$ & $94,4 \%$ & $93,7 \%$ & $93,1 \%$ & $93,2 \%$ & $95,4 \%$ & $95,9 \%$ \\
\hline 5000 & $95,7 \%$ & $95,8 \%$ & $97,6 \%$ & $93,8 \%$ & $93,5 \%$ & $94,4 \%$ & $93,8 \%$ & $96,7 \%$ & $96,7 \%$ \\
\hline 5500 & $99,6 \%$ & $99,8 \%$ & $99,2 \%$ & $97,7 \%$ & $97,9 \%$ & $97,7 \%$ & $97,3 \%$ & $99,5 \%$ & $99,9 \%$ \\
\hline 6000 & $100,0 \%$ & $100,0 \%$ & $100,0 \%$ & $100,0 \%$ & $100,0 \%$ & $100,0 \%$ & $100,0 \%$ & $100,0 \%$ & $100,0 \%$ \\
\hline 6500 & $99,0 \%$ & $99,3 \%$ & $99,3 \%$ & $99,3 \%$ & $98,9 \%$ & $99,3 \%$ & $98,8 \%$ & $98,6 \%$ & $99,1 \%$ \\
\hline 7000 & $97,3 \%$ & $97,5 \%$ & $96,8 \%$ & $97,3 \%$ & $96,9 \%$ & $96,9 \%$ & $96,1 \%$ & $96,4 \%$ & $96,4 \%$ \\
\hline 7500 & $94,1 \%$ & $94,5 \%$ & $93,5 \%$ & $94,1 \%$ & $93,5 \%$ & $94,1 \%$ & $92,1 \%$ & $92,5 \%$ & $92,7 \%$ \\
\hline 8000 & $90,3 \%$ & $90,3 \%$ & $89,7 \%$ & $90,0 \%$ & $89,2 \%$ & $89,3 \%$ & $87,7 \%$ & $87,8 \%$ & $87,9 \%$ \\
\hline 8500 & $85,5 \%$ & $85,5 \%$ & $84,3 \%$ & $84,3 \%$ & $83,7 \%$ & $83,8 \%$ & $82,2 \%$ & $82,3 \%$ & $82,5 \%$ \\
\hline 9000 & $79,3 \%$ & $78,7 \%$ & $78,3 \%$ & $79,3 \%$ & $78,6 \%$ & $78,6 \%$ & $76,5 \%$ & $76,0 \%$ & $76,1 \%$ \\
\hline
\end{tabular}

Tabela 13: Análise estatística do levantamento da curva de torque (usando a distribuição t de Student).

\begin{tabular}{ccccccc}
\hline Rotação & Média & $\begin{array}{c}\text { Desvio } \\
\text { Padrăo }\end{array}$ & Confiança & Incerteza & $\begin{array}{c}\text { Valor } \\
\text { mínimo }\end{array}$ & $\begin{array}{c}\text { Valor } \\
\text { máximo }\end{array}$ \\
\hline 3500 & $86,0 \%$ & $1,0 \%$ & $95,0 \%$ & $1,6 \%$ & $84,4 \%$ & $87,6 \%$ \\
\hline 4000 & $90,6 \%$ & $1,9 \%$ & $95,0 \%$ & $2,9 \%$ & $87,6 \%$ & $93,5 \%$ \\
\hline 4500 & $94,8 \%$ & $1,3 \%$ & $95,0 \%$ & $2,0 \%$ & $92,9 \%$ & $96,8 \%$ \\
\hline 5000 & $95,3 \%$ & $1,5 \%$ & $95,0 \%$ & $2,3 \%$ & $93,1 \%$ & $97,6 \%$ \\
\hline 5500 & $98,7 \%$ & $1,0 \%$ & $95,0 \%$ & $1,6 \%$ & $97,1 \%$ & $100,3 \%$ \\
\hline 6000 & $100,0 \%$ & $0,0 \%$ & $95,0 \%$ & $0,0 \%$ & $100,0 \%$ & $100,0 \%$ \\
\hline 6500 & $99,1 \%$ & $0,2 \%$ & $95,0 \%$ & $0,4 \%$ & $98,7 \%$ & $99,4 \%$ \\
\hline 7000 & $96,8 \%$ & $0,5 \%$ & $95,0 \%$ & $0,8 \%$ & $96,1 \%$ & $97,6 \%$ \\
\hline 7500 & $93,4 \%$ & $0,8 \%$ & $95,0 \%$ & $1,3 \%$ & $92,2 \%$ & $94,7 \%$ \\
\hline 8000 & $89,1 \%$ & $1,1 \%$ & $95,0 \%$ & $1,6 \%$ & $87,5 \%$ & $90,8 \%$ \\
\hline 8500 & $83,8 \%$ & $1,3 \%$ & $95,0 \%$ & $2,0 \%$ & $81,8 \%$ & $85,8 \%$ \\
\hline 9000 & $77,9 \%$ & $1,3 \%$ & $95,0 \%$ & $2,1 \%$ & $75,9 \%$ & $80,0 \%$ \\
\hline
\end{tabular}

Para a normalização da curva do consumo específico de combustível foram usados os dados abaixo. 
Tabela 14: Consumo especifico de combustivel dos motores em g/kW.h.

\begin{tabular}{cccccccccc}
\hline \multirow{2}{*}{ RPM } & \multicolumn{3}{c}{ Motor 1 (E25) } & \multicolumn{3}{c}{ Motor 2 (E25) } & \multicolumn{3}{c}{ Motor 3 (E25) } \\
\cline { 2 - 11 } & $\begin{array}{c}\text { Motor 1 } \\
\text { Teste 1 }\end{array}$ & $\begin{array}{c}\text { Motor 1 } \\
\text { Teste 2 }\end{array}$ & $\begin{array}{c}\text { Motor 1 } \\
\text { Teste 3 }\end{array}$ & $\begin{array}{c}\text { Motor 2 } \\
\text { Teste 1 }\end{array}$ & $\begin{array}{c}\text { Motor 2 } \\
\text { Teste 2 }\end{array}$ & $\begin{array}{c}\text { Motor 2 } \\
\text { Teste 3 }\end{array}$ & $\begin{array}{c}\text { Motor 3 } \\
\text { Teste 1 }\end{array}$ & $\begin{array}{c}\text { Motor 3 } \\
\text { Teste 2 }\end{array}$ & Motor 3 \\
\hline 3500 & 344,8 & 347,5 & 336,2 & 341,6 & 338,6 & 337,4 & 335,6 & 342,6 & 348,5 \\
\hline 4000 & 353,3 & 351,5 & 357,6 & 342,2 & 350,3 & 352,9 & 354,8 & 343,2 & 350,5 \\
\hline 4500 & 358,6 & 356,5 & 352,1 & 364,3 & 357,6 & 352,7 & 367,7 & 364,7 & 364,2 \\
\hline 5000 & 366,3 & 364,7 & 359,1 & 365,5 & 356,7 & 358,8 & 369,0 & 364,1 & 369,7 \\
\hline 5500 & 370,8 & 363,4 & 368,8 & 370,4 & 364,4 & 358,9 & 368,9 & 365,0 & 365,6 \\
\hline 6000 & 375,5 & 373,9 & 369,5 & 379,3 & 372,8 & 374,4 & 374,8 & 368,8 & 366,1 \\
\hline 6500 & 374,4 & 371,3 & 367,5 & 373,5 & 369,6 & 373,1 & 376,2 & 372,1 & 372,7 \\
\hline 7000 & 381,3 & 380,8 & 381,9 & 385,6 & 380,3 & 380,9 & 379,4 & 372,8 & 372,8 \\
\hline 7500 & 392,5 & 391,5 & 396,1 & 391,1 & 391,0 & 386,9 & 388,0 & 378,6 & 380,3 \\
\hline 8000 & 388,8 & 398,2 & 396,2 & 400,7 & 402,7 & 401,8 & 387,4 & 389,3 & 387,2 \\
\hline 8500 & 403,2 & 405,0 & 403,7 & 420,6 & 416,7 & 413,6 & 407,0 & 407,3 & 405,2 \\
\hline 9000 & 422,5 & 433,6 & 422,5 & 446,0 & 444,3 & 446,5 & 427,6 & 431,2 & 418,7 \\
\hline
\end{tabular}

Tabela 15: Análise estatística do levantamento da curva do consumo específico de combustível em $\mathrm{g} / \mathrm{kW}$.h (usando a distribuição t de Student).

\begin{tabular}{ccccccc}
\hline Rotação & Média & $\begin{array}{c}\text { Desvio } \\
\text { Padrão }\end{array}$ & Confiança & Incerteza & $\begin{array}{c}\text { Valor } \\
\text { mínimo }\end{array}$ & $\begin{array}{c}\text { Valor } \\
\text { máximo }\end{array}$ \\
\hline 3500 & 341,43 & 4,817 & $95,0 \%$ & 7,406 & 334,02 & 348,84 \\
\hline 4000 & 350,70 & 5,060 & $95,0 \%$ & 7,779 & 342,93 & 358,48 \\
\hline 4500 & 359,83 & 5,627 & $95,0 \%$ & 8,651 & 351,18 & 368,48 \\
\hline 5000 & 363,77 & 4,612 & $95,0 \%$ & 7,090 & 356,68 & 370,86 \\
\hline 5500 & 366,25 & 3,858 & $95,0 \%$ & 5,931 & 360,32 & 372,18 \\
\hline 6000 & 372,79 & 4,031 & $95,0 \%$ & 6,197 & 366,60 & 378,99 \\
\hline 6500 & 372,26 & 2,593 & $95,0 \%$ & 3,986 & 368,28 & 376,25 \\
\hline 7000 & 379,51 & 4,210 & $95,0 \%$ & 6,473 & 373,04 & 385,99 \\
\hline 7500 & 388,45 & 5,726 & $95,0 \%$ & 8,803 & 379,64 & 397,25 \\
\hline 8000 & 394,69 & 6,514 & $95,0 \%$ & 10,014 & 384,67 & 404,70 \\
\hline 8500 & 409,15 & 6,264 & $95,0 \%$ & 9,630 & 399,52 & 418,78 \\
\hline 9000 & 432,54 & 10,789 & $95,0 \%$ & 16,586 & 415,96 & 449,13 \\
\hline
\end{tabular}




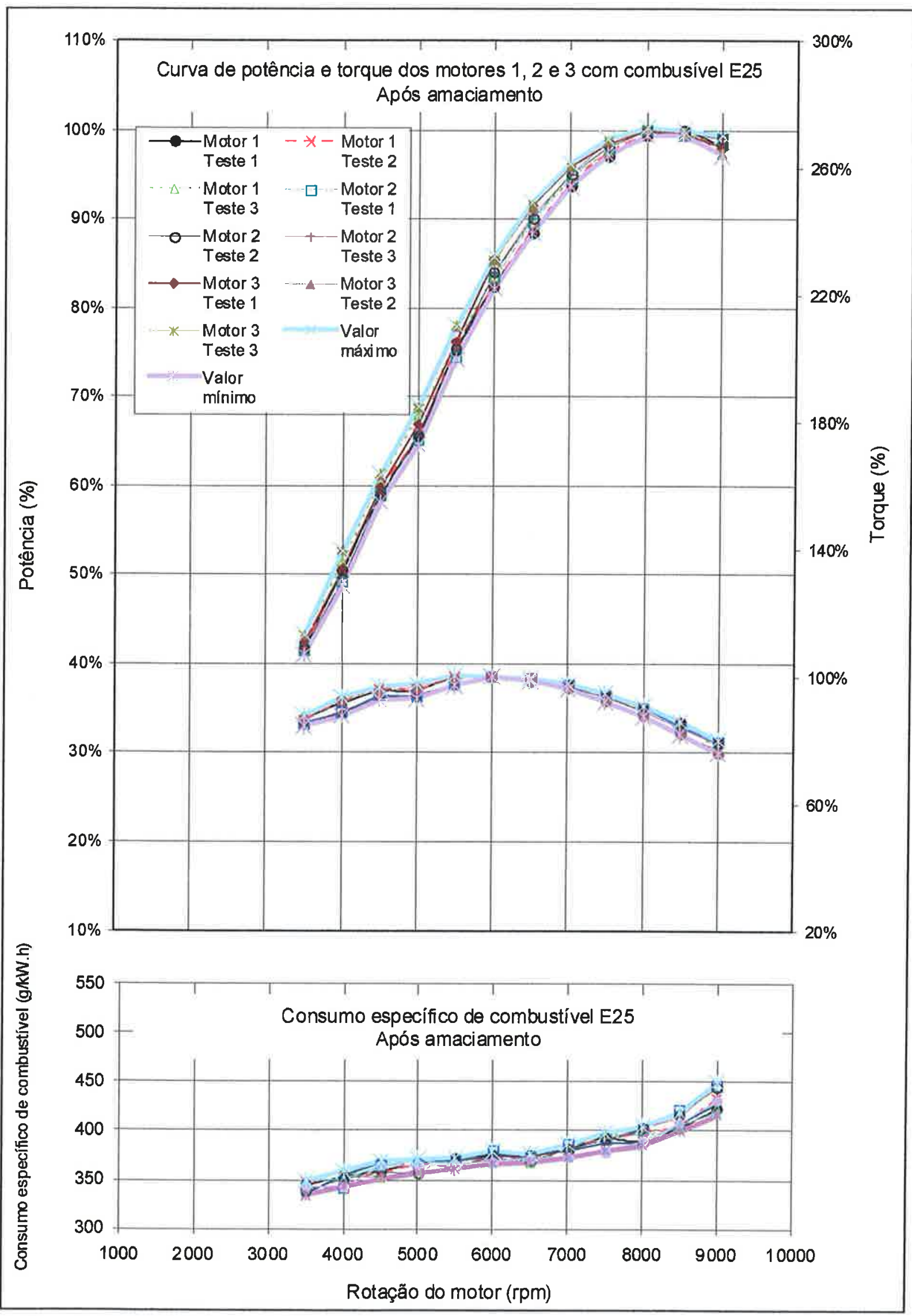

Gráfico 14: Normalização dos três motores. 
No levantamento da curva de potência (Gráfico 15), seguindo a norma NBR 1585, verificou-se que o fator de correção $\alpha$ (que leva em conta as propriedades do ar no local onde o motor foi ensaiado) superava o limite superior. Dessa maneira, foram utilizados os valores observados em todas as medições, quer no levantamento das curvas de potência durante, quer no ensaio de durabilidade.

Após a normalização, os motores foram abastecidos com as misturas preestabelecidas na metodologia. O motor 1 continuou consumindo E25, o motor 2 passou a consumir C-9 e o motor 3 passou a consumir E40.

\subsection{Durabilidade dos motores}

Nenhum dos motores demonstrou problemas relevantes quanto ao funcionamento, nível de óleo e vazamentos após a segunda montagem com verificação dimensional dos componentes.

O ensaio de durabilidade em dinamômetro de bancada desenvolveu-se de acordo com a metodologia proposta. Os resultados obtidos estão no Apêndice C.

No final de cada ciclo de durabilidade foram levantadas novamente as curvas de desempenho.

Para tanto, foi utilizado um medidor de combustível AVL, modelo APU $116 \mathrm{H}$, de capacidade máxima de 60 litros por hora, único disponível. Devido ao seu fundo de escala ser muito elevado, notou-se que as medições de consumo ficaram imprecisas em baixas rotações, considerando a capacidade cúbica dos motores (125cc).

Dessa maneira, para fins de comparação, foram utilizadas apenas medidas de consumo específico em rotação máxima de modo a permitir que os dados coletados fossem conclusivos.

\subsubsection{Análise do motor 1 abastecido com Gasolina C (E25)}

Conforme o Gráfico 15, após o amaciamento, o motor 1 apresentou a potência máxima caracterizada $100 \% \pm 0 \%$, no segundo ciclo o valor de $101 \% \pm 3 \%$. Ao atingir 72 horas e 108 horas observou-se uma redução, respectivamente, de $98 \% \pm 4 \%$ e $96 \% \pm 5 \%$ na potência máxima, relativamente à observada no amaciamento. $\mathrm{A}$ potência máxima do motor avaliado foi medida na rotação de $8.500 \mathrm{rpm}$. Portanto, 
considerando as incertezas das medidas, é possivel afirmar que não houve uma redução significativa na potência.

O torque do motor teve um valor inicial de 100\% $\pm 0 \%$, aumentou para $102 \% \pm 3 \%$ nas primeiras 36 horas e manteve-se em $101 \% \pm 4 \%$ após 72 horas e $101 \% \pm 7 \%$ após 108 horas de durabilidade, relativamente ao observado no amaciamento. Portanto, considerando as incertezas das medidas, é possível afirmar que não houve variações no torque. O torque máximo do motor foi observado na rotação de $6.000 \mathrm{rpm}$.

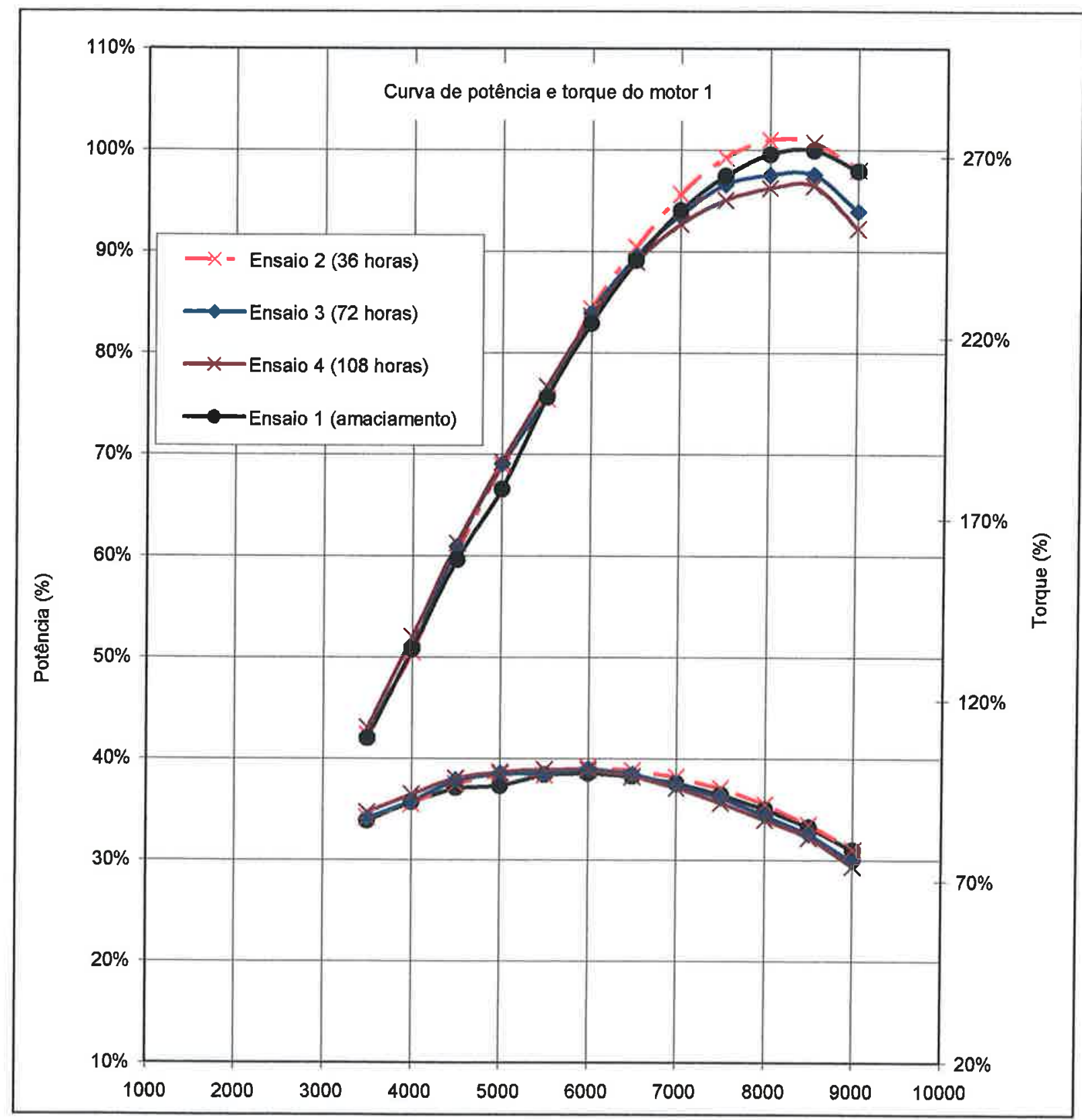

Gráfico 15: Levantamento das curvas de potência e torque do motor 1.

Quanto ao consumo específico, considerando a rotação máxima de 9.000 rpm, após o amaciamento, o valor era de $426,21 \pm 31,88 \mathrm{~g} / \mathrm{kW} . \mathrm{h}$, passou para 
$433,82 \pm 11,99 \mathrm{~g} / \mathrm{kW}$.h com 36 horas. A atingir 72 e 108 horas, o consumo específico

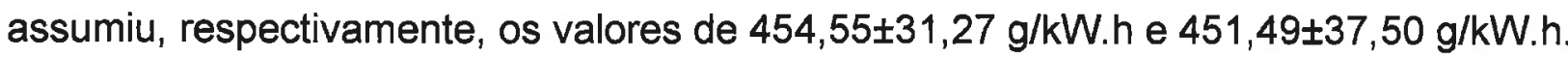

Portanto, considerando as incertezas das medidas, não é possível afirmar que houve o aumento no consumo específico ao longo da vida útil. Os resultados do consumo específico estão no Apêndice D.

\subsubsection{Análise do motor 2 abastecido com gasolina adulterada (C-9)}

O motor 2, que utilizou a mistura com $20 \%$ de C-9, apresentou perda de potência em toda a extensão do ensaio de durabilidade, conforme observado no Gráfico 16.

Nas primeiras 36 horas observou-se uma perda de $4 \% \pm 2 \%$ na potência máxima. Após 72 horas a perda de potência chegou a $7 \% \pm 1 \%$, e nas 108 horas a $6 \% \pm 2 \%$. Na primeira medição, antes do início do ensaio de durabilidade, foi utilizado E25. A potência máxima do motor avaliado foi medida a $8.500 \mathrm{rpm}$. Portanto, considerando as incertezas das medidas, é possível afirmar que houve uma redução na potência de $6 \% \pm 2 \%$ na última medição do motor 2 .

Considerando que a variação máxima esperada no valor da potência máxima era de $7 \%$ durante o ensaio de durabilidade, o motor avaliado estaria reprovado.

O torque máximo do motor teve um decréscimo de $3 \% \pm 2 \% 3 \% \pm 1 \%$ nas primeiras 36 horas, reduziu para $5 \% \pm 3 \%$ nas 72 horas e manteve-se em $3 \% \pm 2 \%$ nas 108 horas.

O torque máximo do motor era obtido a $6.000 \mathrm{rpm}$

O consumo específico, considerando a rotação máxima de 9.000 rpm, após o

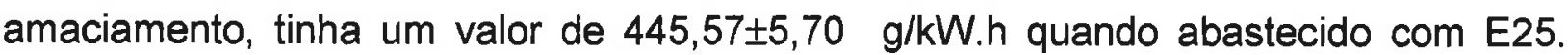
Após 36 horas, na primeira medição utilizando C-9, o consumo específico era de

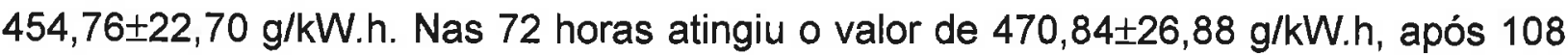

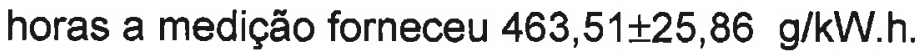

Portanto, não é possível afirmar que houve o aumento no consumo específico do motor C-9 ao longo do ensaio de durabilidade, da mesma forma que ocorreu com o motor 1. É importante mencionar que o combustível E25, utilizado na primeira medição, tinha uma massa específica de $748,3 \mathrm{~kg} / \mathrm{m}^{3}$ e a mistura com $20 \%$ de C-9 tinha uma massa específica de $767,4 \mathrm{~kg} / \mathrm{m}^{3}$. Os dados do consumo estão no Apêndice D. 


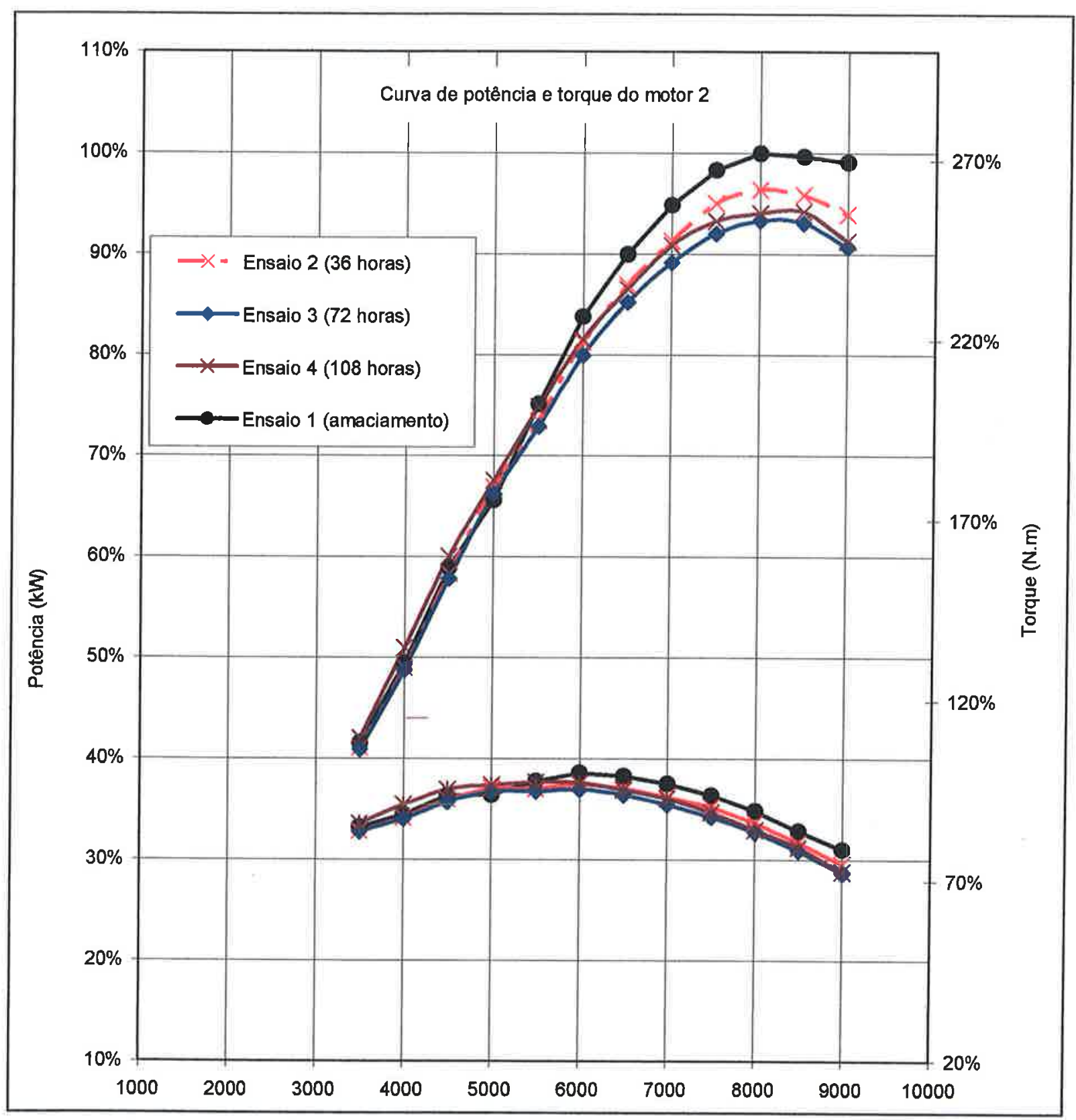

Gráfico 16: Levantamento das curvas de potência e torque do motor 2.

\subsubsection{Análise do motor 3 abastecido com gasolina adulterada (E40)}

O motor 3, que utilizou a mistura E40 após o amaciamento, apresentou uma queda de potência ainda mais acentuada que o motor 1 e 2 durante o ensaio de durabilidade, conforme apresentado no Gráfico 17.

Devido ao combustível utilizado, no levantamento das curvas de potência e torque, não foi possível fazer medições na rotação de $3.500 \mathrm{rpm}$. A mistura ar e combustivel ficou muito pobre de modo que o motor não se mantinha em funcionamento nessa rotação. 
Nas primeiras 36 horas, a redução do valor da potência máxima atingiu $2 \% \pm 2 \%$; após 72 horas essa redução era de $6 \% \pm 4 \%$. Após 108 horas a perda de potência máxima chegou a $8 \% \pm 3 \%$.

Foi utilizado E25 na primeira medição antes do início da durabilidade. A potência máxima do motor avaliado foi medida na rotação de 8.500 rpm.

Considerando a variação máxima de $7 \%$ durante o ciclo de vida acelerado proposto, o motor 3 estaria reprovado.

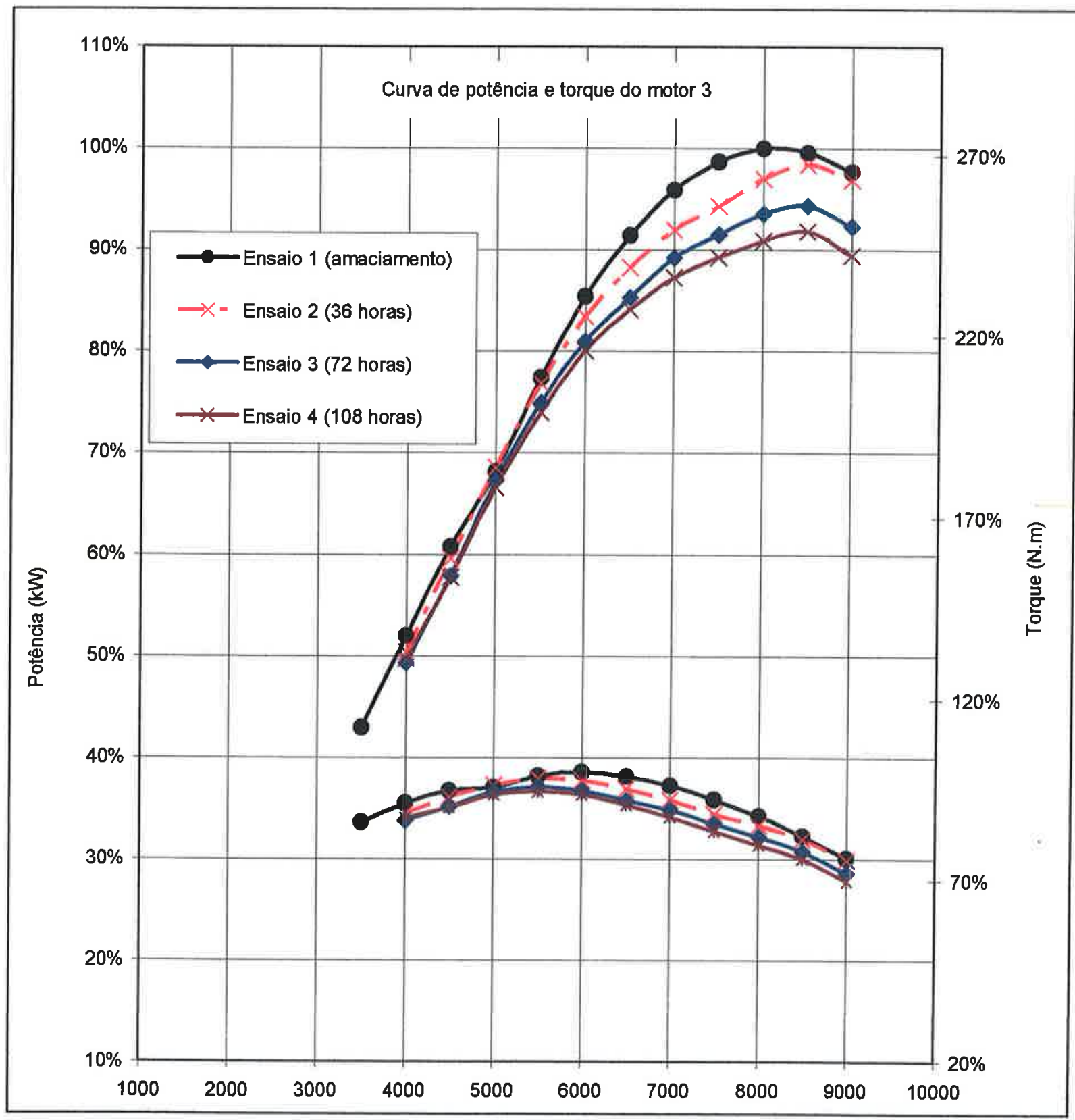

Gráfico 17: Levantamento das curvas de potência e torque do motor 3. 
O torque máximo do motor teve um decréscimo de $2 \% \pm 1 \%$ nas primeiras 36 horas. Esse decréscimo se acentuou, tendo atingido $5 \% \pm 4 \%$ após 72 horas e $6 \% \pm 4 \%$ após 108 horas de ensaio de durabilidade.

O torque máximo do motor foi observado na rotação de $6.000 \mathrm{rpm}$.

No consumo específico, considerando a rotação máxima de 9.000 rpm, após o amaciamento, teve um valor inicial de $425,84 \pm 31,87 \mathrm{~g} / \mathrm{kW}$.h quando abastecido com E25. Após 36 horas, na primeira medição utilizando E40, teve o consumo específico de $438,00 \pm 8,53 \mathrm{~g} / \mathrm{kW}$.h.

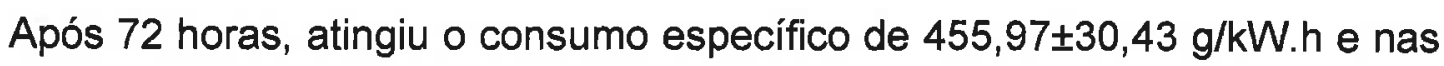
108 horas, na última medição, teve $474,07 \pm 12,56 \mathrm{~g} / \mathrm{kW} . \mathrm{h}$.

Portanto o consumo específico de combustivel aumentou em $11,3 \%$ ao longo da vida útil, o que era praticamente o dobro dos observados nos motores 1 e 2 .

No motor 3, deve-se considerar que, na primeira medição, o combustível E25 tem uma massa específica de $748,3 \mathrm{~kg} / \mathrm{m}^{3}$ e com a adição de $15 \%$ de $E 40$ passou para $759,4 \mathrm{~kg} / \mathrm{m}^{3}$. Os dados do consumo estão no Apêndice D.

\subsection{Medições nas revisões periódicas}

Após os ciclos de durabilidade, foram realizadas as revisões periódicas. A folga de válvulas de admissão e escape, eletrodo da vela de ignição, compressão do motor e consumo de óleo foram monitoradas em toda a extensão do experimento.

As folgas de válvulas apresentaram os seguintes resultados, conforme as Tabelas 16, 17, 18 e 19:

Tabela 16: Folga de válvulas no amaciamento (mm).

\begin{tabular}{ccccc}
\hline \multirow{2}{*}{ Motor } & \multicolumn{2}{c}{$\begin{array}{c}\text { Valores ajustados } \\
\text { para o amaciamento }\end{array}$} & \multicolumn{2}{c}{$\begin{array}{c}\text { Valores en contrados } \\
\text { depois do amaciamento }\end{array}$} \\
\cline { 2 - 5 } & Admissão & Escape & Admissåo & Escape \\
\hline E25 & 0,100 & 0,120 & 0,120 & 0,120 \\
\hline C9 & 0,100 & 0,120 & 0,110 & 0,140 \\
\hline E40 & 0,100 & 0,120 & 0,130 & 0,170 \\
\hline
\end{tabular}

Tabela 17: Folga de válvulas no primeiro ciclo durabilidade (mm).

\begin{tabular}{ccccc}
\hline \multirow{2}{*}{ Motor } & \multicolumn{2}{c}{$\begin{array}{c}\text { Valores ajustados } \\
\text { para } 01^{\circ} \text { ciclo }\end{array}$} & \multicolumn{2}{c}{$\begin{array}{c}\text { Valores encontrados } \\
\text { depois do } 1^{\circ} \text { ciclo }\end{array}$} \\
\cline { 2 - 5 } & Admissão & Escape & Admissão & Escape \\
\hline E25 & 0,100 & 0,120 & 0,100 & 0,120 \\
\hline C9 & 0,100 & 0,120 & 0,080 & 0,100 \\
\hline E40 & 0,100 & 0,120 & 0,100 & 0,120 \\
\hline
\end{tabular}


Tabela 18: Folga de válvulas no segundo ciclo durabilidade (mm).

\begin{tabular}{ccccc}
\hline \multirow{2}{*}{ Motor } & \multicolumn{2}{c}{$\begin{array}{c}\text { Valores mantidos } \\
\text { para o } 2^{\circ} \text { ciclo }\end{array}$} & \multicolumn{2}{c}{$\begin{array}{c}\text { Valores encontrados } \\
\text { dep ois do } 2^{\circ} \text { ciclo }\end{array}$} \\
\cline { 2 - 5 } & Admissão & Escape & Admissão & Escape \\
\hline E25 & 0,100 & 0,120 & 0,110 & 0,120 \\
\hline C9 & 0,080 & 0,100 & 0,080 & 0,100 \\
\hline E40 & 0,100 & 0,120 & 0,100 & 0,110 \\
\hline
\end{tabular}

Tabela 19: Folga de válvulas no terceiro ciclo durabilidade (mm).

\begin{tabular}{ccccc}
\hline \multirow{2}{*}{ Motor } & \multicolumn{2}{c}{$\begin{array}{c}\text { Valores mantidos } \\
\text { para o } 3^{\circ} \text { ciclo }\end{array}$} & \multicolumn{2}{c}{$\begin{array}{c}\text { Valores encontrados } \\
\text { depois do } 3^{\circ} \text { ciclo }\end{array}$} \\
\cline { 2 - 5 } & Admissão & Escape & Admissão & Escape \\
\hline E25 & 0,110 & 0,120 & 0,120 & 0,120 \\
\hline C9 & 0,080 & 0,100 & 0,090 & 0,110 \\
\hline E40 & 0,100 & 0,110 & 0,100 & 0,110 \\
\hline
\end{tabular}

As folgas das válvulas ficaram dentro dos limites em todos os motores com exceção do período de amaciamento, momento em que há o assentamento das válvulas (PUBLICAÇÃO YAMAHA, 2000).

As folgas dos eletrodos geraram os seguintes resultados, conforme a Tabela 20:

Tabela 20: Folga do eletrodo da vela de igniçăo $(\mathrm{mm})$.

\begin{tabular}{ccccc}
\hline Motor & $1^{\circ}$ Ciclo & $2^{\circ}$ Ciclo & $3^{\circ}$ Ciclo & Pós-ciclo \\
\hline E25 & 0,60 & 0,60 & 0,60 & 0,60 \\
\hline C9 & 0,60 & 0,60 & 0,65 & 0,65 \\
\hline E40 & 0,65 & 0,65 & 0,70 & 0,70 \\
\hline
\end{tabular}

A folga do eletrodo manteve-se a mesma para o motor E25, enquanto que para os motores C-9 e E40 teve um aumento de 0,05 milímetros. Todas as folgas estão dentro dos limites permitidos em projeto.

As medições das pressões de final de compressão dos motores geraram os seguintes resultados, conforme a Tabela 21 :

Tabela 21: Compressão dos motores $\left(\mathrm{kgf} / \mathrm{cm}^{2}\right)$.

\begin{tabular}{cccccc}
\hline \multirow{2}{*}{ Motor } & \multicolumn{3}{c}{ Teste realizado após o término de cada etapa } & \multirow{2}{*}{ Pós-ciclo } \\
\cline { 2 - 5 } & Amadiamento & $1^{\circ}$ Ciclo & $2^{\circ}$ Ciclo & $3^{\circ}$ Ciclo & \\
\hline E25 & 14,6 & 12,2 & 11,8 & 11,8 & 12,4 \\
\hline C9 & 13,8 & 15,6 & 16,9 & 15,6 & 15,6 \\
\hline E40 & 15,8 & 16,0 & 15,3 & 15,4 & 15,8 \\
\hline
\end{tabular}


Os resultados referem-se à última medição após o levantamento das curvas de potência antes de iniciar a desmontagem dos motores.

Todos os resultados na medição de compressão estão de acordo com a especificação em projeto.

E por último, foram medidos os consumos de óleo para cada motor a cada ciclo de durabilidade, conforme as Tabelas 22, 23 e 24.

Tabela 22: Consumo de óleo dos motores após o primeiro ciclo em gramas e gramas por hora.

\begin{tabular}{|c|c|c|c|c|c|}
\hline \multirow{2}{*}{ Motor } & \multirow{2}{*}{ Valor inicial } & \multirow{2}{*}{$\begin{array}{l}\text { Adição } \\
\text { gramas }\end{array}$} & \multirow[t]{2}{*}{ Valor final } & \multicolumn{2}{|c|}{ Consumo } \\
\hline & & & & gramas & $\mathrm{g} / \mathrm{h}$ \\
\hline E25 & 890 & 413 & 791 & 512 & 14,2 \\
\hline C9 & 890 & 340 & 789 & 441 & 12,3 \\
\hline $\mathrm{E} 40$ & 890 & 323 & 704 & 509 & 14,1 \\
\hline
\end{tabular}

Tabela 23: Consumo de óleo dos motores após o segundo ciclo em gramas e gramas por hora.

\begin{tabular}{|c|c|c|c|c|c|}
\hline \multirow{2}{*}{ Motor } & \multirow[t]{2}{*}{ Valor inicial } & \multirow{2}{*}{$\begin{array}{l}\text { Adição } \\
\text { gramas }\end{array}$} & \multirow[t]{2}{*}{ Valor final } & \multicolumn{2}{|c|}{ Consumo } \\
\hline & & & & gramas & $g / h$ \\
\hline E25 & 890 & 466 & 831 & 525 & 14,6 \\
\hline $\mathrm{Cg}$ & 890 & 314 & 750 & 454 & 12,6 \\
\hline $\mathrm{E} 40$ & 890 & 303 & 758 & 435 & 12,1 \\
\hline
\end{tabular}

Tabela 24: Consumo de óleo dos motores após o terceiro ciclo em gramas e gramas por hora.

\begin{tabular}{|c|c|c|c|c|c|}
\hline \multirow{2}{*}{ Motor } & \multirow{2}{*}{ Valor inicial } & \multirow{2}{*}{$\begin{array}{l}\text { Adiçăo } \\
\text { gramas }\end{array}$} & \multirow[t]{2}{*}{ Valor final } & \multicolumn{2}{|c|}{ Consumo } \\
\hline & & & & gramas & $\mathrm{g} / \mathrm{h}$ \\
\hline E25 & 890 & 306 & 761,5 & 435 & 12,1 \\
\hline $\mathrm{Cg}$ & 890 & 209 & 714 & 385 & 10,7 \\
\hline $\mathrm{E} 40$ & 890 & 338 & 789 & 439 & 12,2 \\
\hline
\end{tabular}

O consumo de óleo foi próximo aos dos demais motores.

A altura da bóia de combustível foi monitorada, porém não houve variação de altura em nenhum dos motores pelo método de medição utilizado. Todos iniciaram e terminaram com a altura da bóia de 6,0 mm abaixo da linha do carburador.

\subsection{Análise das emissões de poluentes}

4.6.1 Análise do motor 1 abastecido com Gasolina C (E25)

A concentração de $\mathrm{CO}_{2}$ nos gases de escapamento após o amaciamento, na rotação de potência máxima, era de $9,54 \% \pm 1,00 \%$ e passou para $9,93 \% \pm 0,92 \%$ após o 
primeiro ciclo, para $10,48 \% \pm 1,65 \%$ no segundo ciclo e para $10,31 \% \pm 0,24 \%$ no último ciclo. Portanto, considerando as incertezas das medidas, é possivel verificar que houve um aumento de $8 \% \pm 2,32 \%$ na emissão de $\mathrm{CO}_{2}$

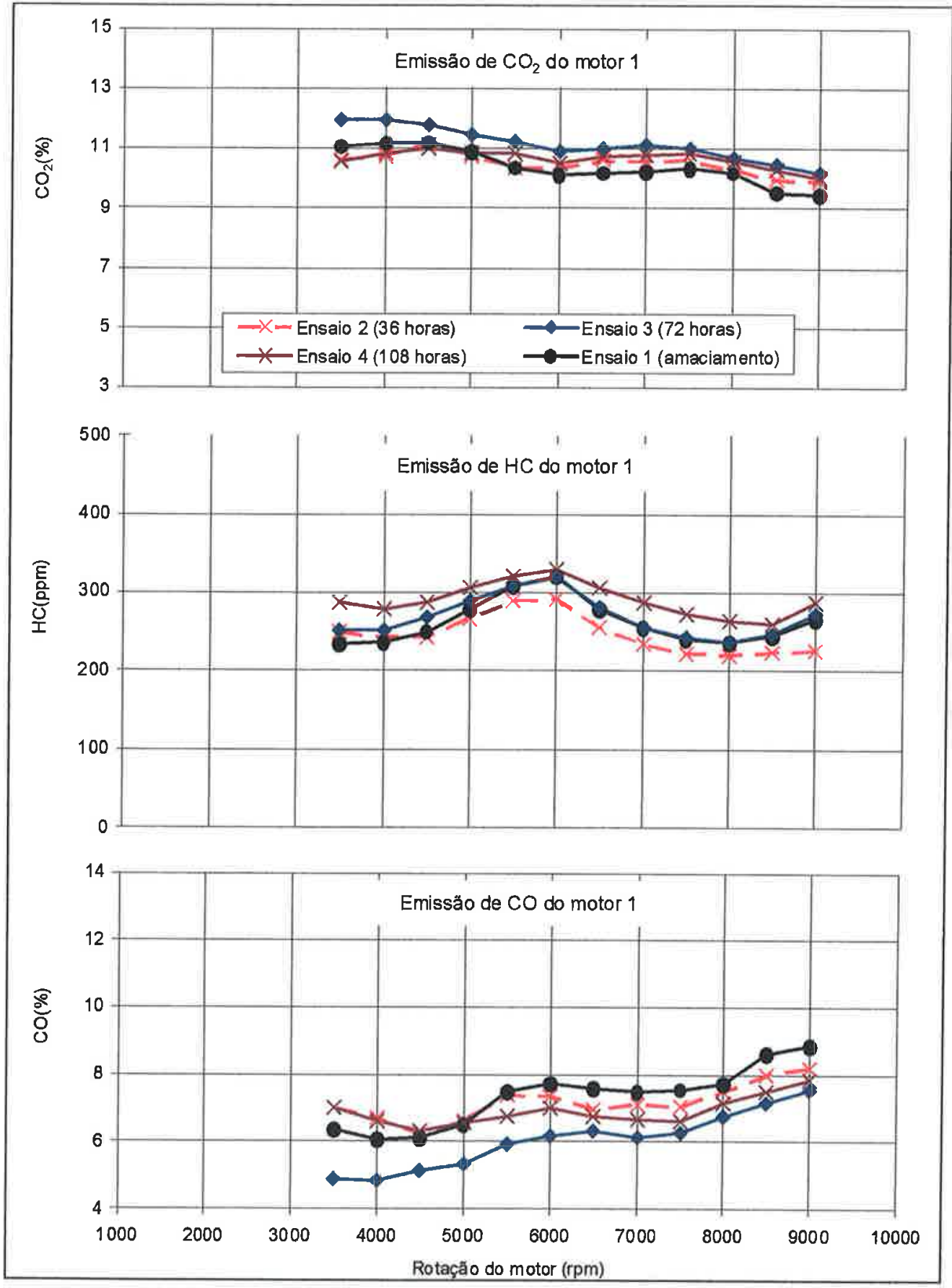

Gráfico 18: Emissão dos gases de escape $\mathrm{CO}_{2}, \mathrm{HC}$ e $\mathrm{CO}$ do motor 1 .

Esses resultados, associados ao fato de ter havido uma redução no valor nominal da potência em 4\%, demonstra uma perda de eficiência do motor ao longo do ensaio de durabilidade. O Gráfico 18 apresenta as emissões de $\mathrm{CO}_{2}, \mathrm{HC}$ e $\mathrm{CO}$ do motor 1 entre 3.500 a 9.000 rpm em plena carga. 
A emissão de $\mathrm{HC}$ após o amaciamento, na rotação de potência máxima, que era de $244 \pm 45 \mathrm{ppm}$, reduziu-se para $224 \pm 27 \mathrm{ppm}$ após o primeiro ciclo, manteve-se em $248 \pm 96 \mathrm{ppm}$ no segundo ciclo e aumentou para $259 \pm 23 \mathrm{ppm}$ no final do ensaio de durabilidade.

Apesar de ser coerente esperar o aumento da emissão de HC, considerando as incertezas das medidas, estatisticamente não é possivel afirmar que isso tenha ocorrido durante o ensaio de durabilidade.

A emissão de $\mathrm{CO}$, na rotação de potência máxima, após o amaciamento, teve um valor de $8,61 \% \pm 1,02 \%$, reduziu-se para $7,99 \% \pm 1,50 \%$ após o primeiro ciclo e para $7,15 \% \pm 2,63 \%$ após o segundo ciclo, atingindo $7,50 \% \pm 1,25 \%$ no final do ensaio. Da mesma forma, considerando as incertezas das medidas, não é possível afirmar que houve uma alteração nas emissões de $\mathrm{CO}$.

\subsubsection{Análise do motor 2 abastecido com gasolina adulterada (C-9)}

Nas medições dos gases de escape do motor 2, após o amaciamento, utilizou o combustível E25, e nos três próximos ciclos, o combustível C-9.

A emissão de $\mathrm{CO}_{2}$ após o amaciamento, na rotação de potência máxima, teve um valor de $9,64 \% \pm 0,55 \%$ com 0 uso de E25, de forma estatisticamente semelhante ao motor 1. Essa semelhança também foi verificada para as emissões de $\mathrm{CO}$ e $\mathrm{HC}$.

Passou para $9,68 \% \pm 0,14 \%$ após o primeiro ciclo com o uso do C-9, aumentou para $10,06 \% \pm 0,49 \%$ no segundo ciclo e para $10,39 \% \pm 0,97 \%$ no último ciclo.

Portanto, considerando as incertezas das medidas com o uso do C-9, não é possível afirmar que a emissão de $\mathrm{CO}_{2}$ alterou durante o ensaio de durabilidade.

A tendência do aumento $\mathrm{CO}_{2}$, associados ao fato de ter havido uma redução no valor da potência em $6 \% \pm 2 \%$, demonstram uma perda de eficiência do motor 2 ao longo do ensaio de durabilidade.

A emissão de $\mathrm{HC}$, na rotação de potência máxima, após o amaciamento, teve um valor de $265 \pm 65 \mathrm{ppm}$, reduziu para $233 \pm 21 \mathrm{ppm}$ após o primeiro ciclo, mantevese em $242 \pm 48 p p m$ no segundo ciclo e atingiu $244 \pm 56 \mathrm{ppm}$ no terceiro ciclo.

Portanto, considerando as incertezas das medidas, não é possível afirmar que as emissões de $\mathrm{HC}$ sofreram alterações durante toda a durabilidade. 
O Gráfico 19 apresenta as emissões de $\mathrm{CO}_{2}, \mathrm{HC}$ e $\mathrm{CO}$ do motor 2 funcionando em plena carga entre 3.500 a $9.000 \mathrm{rpm}$.

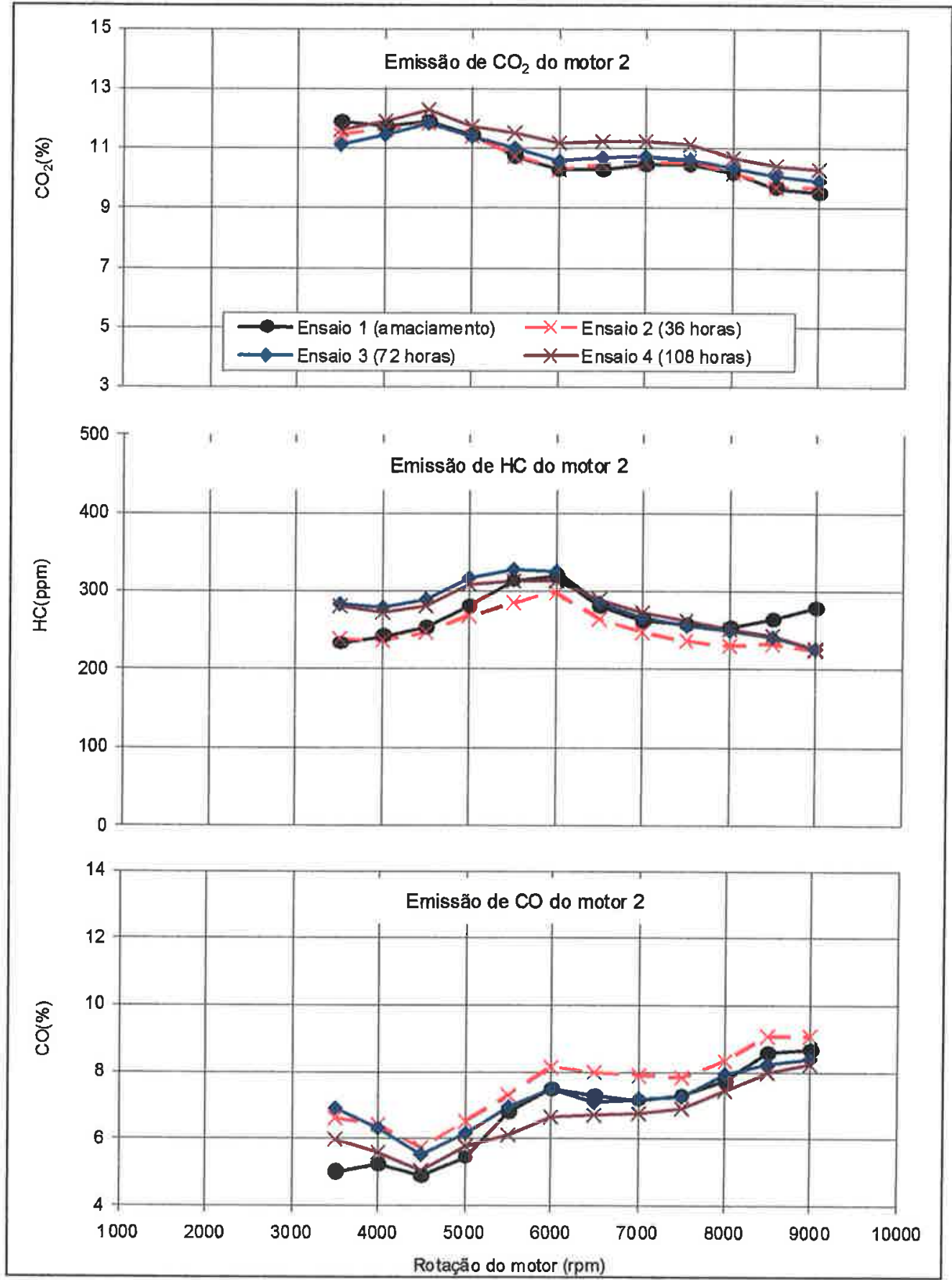

Gráfico 19: Emissão dos gases de escape $\mathrm{CO}_{2}, \mathrm{HC}$ e $\mathrm{CO}$ do motor 2.

A emissão de $\mathrm{CO}$, na rotação de potência máxima, após o amaciamento, teve um valor de $8,58 \% \pm 0,69 \%$ com o uso do E25. Gerou 9,08\% 0,52\% após o primeiro ciclo e $8,23 \% \pm 0,96 \%$ após o segundo ciclo. Terminou com o valor de $8,00 \% \pm 0,93 \%$ na última medição.

Portanto, considerando as incertezas das medidas, não é possível afirmar que a emissão de CO alterou-se ao longo do ensaio de durabilidade. 
4.6.3 Análise do motor 3 abastecido com gasolina adulterada (E40)

O Gráfico 20 apresenta as emissões de $\mathrm{CO}_{2}, \mathrm{HC}$ e $\mathrm{CO}$ do motor 3 funcionando em plena carga entre 3.500 a $9.000 \mathrm{rpm}$.

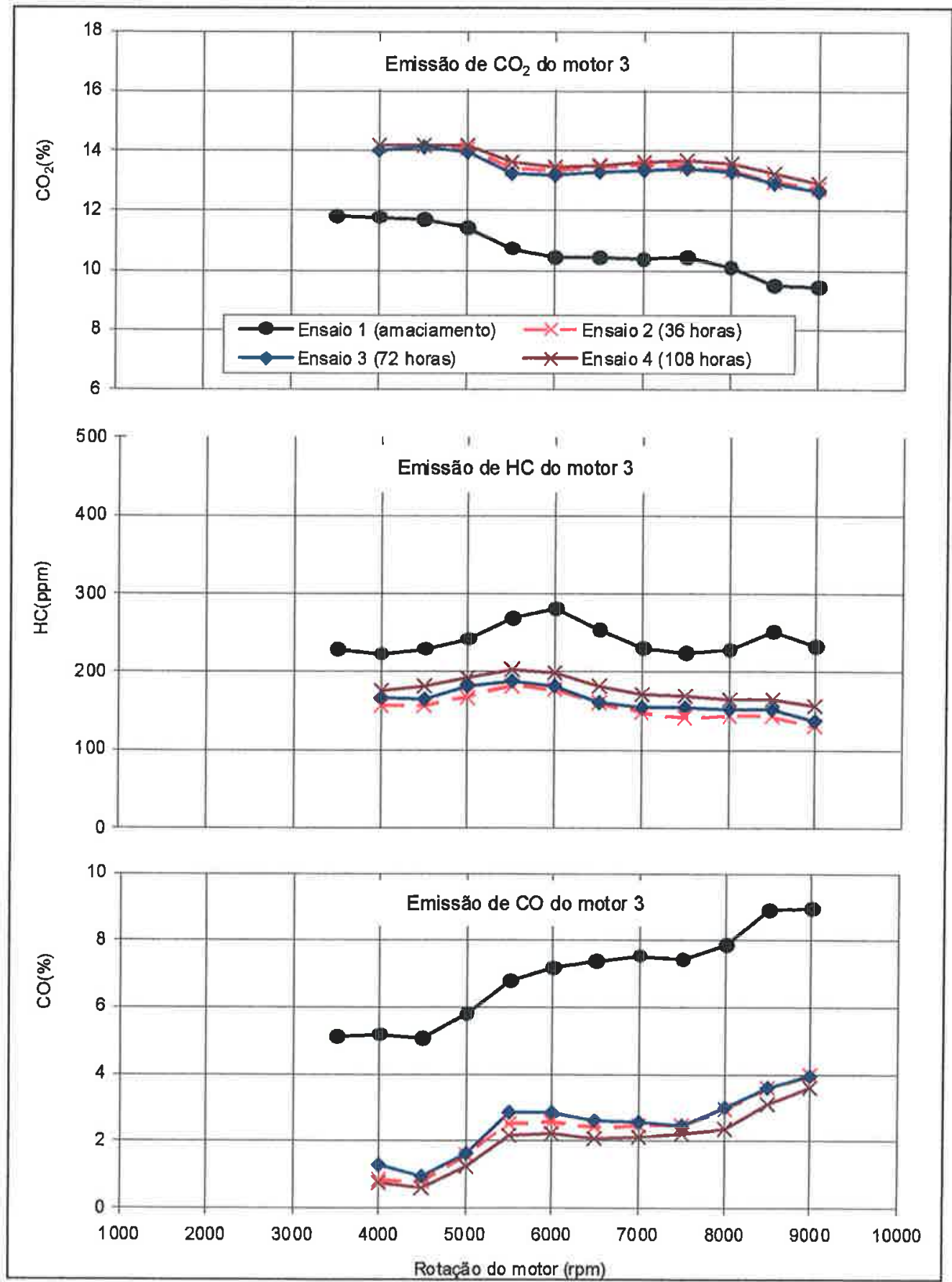

Gráfico 20: Emissão dos gases de escape $\mathrm{CO}_{2}, \mathrm{HC}$ e $\mathrm{CO}$ do motor 3 .

Nas medições dos gases de escape do motor 3, após o amaciamento, utilizou o combustível E25, e nos três próximos ciclos, o combustível E40.

A emissão de $\mathrm{CO}_{2}$ após o amaciamento, na rotação de potência máxima, teve um valor de $9,48 \% \pm 0,83 \%$ com o uso de $E 25$, de forma estatisticamente 
semelhante ao motor 1. Essa semelhança também foi verificada para as emissões de $\mathrm{CO}$ e HC.

Com o uso de E40, gerou $12,98 \% \pm 0,37 \%$ no final o primeiro ciclo, $12,90 \% \pm 0,44 \%$ no segundo ciclo e aumentou em $13,25 \% \pm 0,55 \%$ no último ciclo.

Portanto, considerando as incertezas das medidas, não é possível afirmar que houve alteração na emissão de $\mathrm{CO}_{2}$

A emissão de HC, na rotação de potência máxima, após o amaciamento, teve um valor de $251 \pm 21 \mathrm{ppm}$, reduziu-se para $143 \pm 40$ ppm após o primeiro ciclo, gerou $153 \pm 15$ ppm no segundo ciclo e $165 \pm 9$ ppm no terceiro ciclo.

Portanto, considerando as incertezas das medidas, não é possível afirmar que a emissão de $\mathrm{HC}$ se alterou com o uso do E40.

A emissão de $\mathrm{CO}$, na rotação de potência máxima, após o amaciamento, teve um valor nominal de $8,91 \% \pm 1,10 \%$, reduziu em $3,58 \% \pm 0,60 \%$ após o primeiro ciclo, manteve-se em $3,58 \% \pm 0,34 \%$ após o segundo ciclo e $3,11 \% \pm 0,53 \%$ na última medição.

Portanto, considerando as incertezas das medidas, não é possível afirmar que houve alteração nas emissões de CO durante o ensaio de durabilidade.

Entretanto, nominalmente, verificam-se tendências de aumento nas concentrações de $\mathrm{CO}_{2}$ e $\mathrm{HC}$, e de redução nas concentrações de $\mathrm{CO}$.

$\mathrm{O}$ aumento na produção de $\mathrm{CO}_{2}$ está coerentemente associado ao aumento de consumo durante o ensaio. A redução no CO ocorre pela maior disponibilidade de oxigênio proveniente do próprio combustível e pelo empobrecimento gradual da mistura observada no decorrer do ensaio. O aumento da concentração de HC está associado ao desgaste do motor.

\subsection{Relações estequiométricas}

\subsubsection{Reação estequiométrica do E25}

A reação de combustão completa para o combustível E25 pode ser escrita da seguinte maneira:

$$
\mathrm{A} \mathrm{C}_{8} \mathrm{H}_{14}+\mathrm{B} \mathrm{C}_{2} \mathrm{H}_{5} \mathrm{OHn} \mathrm{H}_{2} \mathrm{O}+\mathrm{C}\left(\mathrm{O}_{2}+3,76 \mathrm{~N}_{2}\right) \longrightarrow \mathrm{DCO}_{2}+\mathrm{E} \mathrm{H}_{2} \mathrm{O}+\mathrm{G} \mathrm{N}_{2}
$$


Os valores de A e B são definidos a partir da consideração que $75 \%$ do volume de combustível é constituído de gasolina pura (molécula média: $\mathrm{C}_{8} \mathrm{H}_{14}$ ) e os $25 \%$ restantes são de AEAC com teor alcoólico de $99,3 \%$ em massa, conforme caracterização do álcool etílico anidro carburante utilizado nos ensaios. Os valores de C, D, E e G são obtidos considerando a estequiometria da reação.

Ainda de acordo com os certificados emitidos pelas distribuidoras de combustivel, adquiridos para esse experimento, a massa específica da gasolina é 0,74 $\mathrm{kg} / \mathrm{l}$ e a do álcool anidro de 0,79 kg/l.

Desta forma, a massa específica $\bar{\rho}$ da mistura E25 é descrita na equação 7:

$$
\begin{gathered}
\bar{\rho}=0,75 \times 0,74+0,25 \times 0,79 \\
\bar{\rho}=0,7525 \mathrm{~kg} / \mathrm{l}(7)
\end{gathered}
$$

Portanto, em massa, a gasolina corresponde a $73,75 \%(0,74 \times 0,75 / 0,7525) \mathrm{da}$ massa total da mistura e o AEAC corresponde a $26,25 \%(0,79 \times 0,25 / 0,7525)$.

A massa molecular da gasolina $\left(\mathrm{C}_{8} \mathrm{H}_{14}\right)$ é de $110,200 \mathrm{~g} / \mathrm{mols}$ e a do AEAC $\left(\mathrm{C}_{2} \mathrm{H}_{5} \mathrm{OHn} \mathrm{H}_{2} \mathrm{O}\right)$ é de $46,069 \mathrm{~g} / \mathrm{mols}$ acrescida da água presente que possui massa molecular $18,015 \mathrm{~g} / \mathrm{mols}$.

Pode-se, então, escrever conforme a equação 8:

$$
\% \text { água em massa }=\frac{n^{\prime} \mathrm{H}_{2} \mathrm{O}}{\mathrm{C}_{2} \mathrm{H}_{5} \mathrm{OH}+n^{\prime} \mathrm{H}_{2} \mathrm{O}}
$$

Substituindo os valores conhecidos na equação acima, tem-se:

$$
\begin{aligned}
0,007 & =\frac{18,015 \times n^{\prime}}{46,069+18,015 \times n^{\prime}} \\
n^{\prime} & =0,018 \\
n^{\prime} H_{2} \mathrm{O} & =0,018 \times 18,015=0,324 \mathrm{~g} / \mathrm{mols}
\end{aligned}
$$

Portanto:

$$
\begin{aligned}
46,393 B & =0,2625(110,200 A+46,393 B) \\
110,200 A & =0,7375(110,200 A+46,393 B)
\end{aligned}
$$

Chamando a massa total de combustível $(110,200 A+46,393$ B) de $X$, obtém-se de acordo com a equação 9 e 10: 


$$
\begin{aligned}
& A=\frac{0,7375 X}{110,200}=0,006692 X \\
& B=\frac{0,2625 X}{46,393}=0,005658 X
\end{aligned}
$$

Estabelecida a proporção acima, foram utilizados os valores $A=0,6692$ e $B=$ 0,5658 .

Realizando, então, o balanço da equação química, obtém-se:

$$
0,6692 \mathrm{C}_{8} \mathrm{H}_{14}+0,5658 \mathrm{C}_{2} \mathrm{H}_{5} \mathrm{OHO}, 018 \mathrm{H}_{2} \mathrm{O}+9,2517\left(\mathrm{O}_{2}+3,76 \mathrm{~N}_{2}\right)
$$$$
6,4852 \mathrm{CO}_{2}+6,1169 \mathrm{H}_{2} \mathrm{O}+34,7864 \mathrm{~N}_{2}
$$

Dessa maneira, a relação mássica combustível-ar estequiométrica do combustível E25 $\left(F_{25}\right)$ está na equação 11:

$$
F_{25}=\frac{0,6692 \times 110,200+0,5658 \times 46,393}{9,2517 \times(31,998+3,76 \times 28,014)}=\frac{1}{12,71}=0,0787
$$

\subsubsection{Reação estequiométrica da mistura contendo solvente C-9}

A reação de combustão completa da mistura com solvente $\mathrm{C}-9$, como utilizada nos ensaios, pode ser escrita da seguinte maneira:

$A \mathrm{C}_{8} \mathrm{H}_{14}+\mathrm{B} \mathrm{C}_{9} \mathrm{H}_{12}+\mathrm{C} \mathrm{C}_{2} \mathrm{H}_{5} \mathrm{OHn} \mathrm{H}_{2} \mathrm{O}+\mathrm{D}\left(\mathrm{O}_{2}+3,76 \mathrm{~N}_{2}\right) \longrightarrow \mathrm{ECO}_{2}+\mathrm{G} \mathrm{H}_{2} \mathrm{O}+\mathrm{H} \mathrm{N}_{2}$

Os valores de $A, B$ e $C$ são definidos a partir da consideração que $55 \%$ do volume de combustivel é constituído de gasolina pura (molécula média: $\mathrm{C}_{8} \mathrm{H}_{14}$ ), $20 \%$ é constituído por solvente C-9 e os $25 \%$ restantes são de AEAC (com teor alcoólico de $99,3 \%$ em massa). Os valores de $D, E, G$ e $H$ são obtidos considerando a estequiometria da reação.

De acordo com os certificados emitidos pelas distribuidoras de combustível, adquiridos para esse experimento, a massa específica da gasolina é $0,74 \mathrm{~kg} / \mathrm{l}$, a do solvente C-9 de 0,87 kg/l e a do álcool anidro de $0,79 \mathrm{~kg} /$; o teor alcoólico do AEAC é de $99,3 \%$ em massa.

Desta forma, a massa específica $(\bar{\rho})$ para a mistura é descrita na equação 12: 


$$
\begin{gathered}
\bar{\rho}=0,55 \times 0,74+0,20 \times 0,87+0,25 \times 0,79 \\
\bar{\rho}=0,7785 \mathrm{~kg} / \mathrm{l}(12)
\end{gathered}
$$

Portanto, em massa, a gasolina corresponde a 52,28\% $(0,74 \times 0,55 / 0,7785) \mathrm{da}$ massa total da mistura, o solvente C-9 corresponde a $22,35 \%(0,87 \times 0,2010,7785)$ e o AEAC corresponde a $25,37 \%(0,79 x 0,25 / 0,7785)$.

A massa molecular da gasolina $\left(\mathrm{C}_{8} \mathrm{H}_{14}\right)$ é $110,200 \mathrm{~g} / \mathrm{mols}$, a do solvente C-9 $\left(\mathrm{C}_{9} \mathrm{H}_{12}\right)$ é $120,195 \mathrm{~g} / \mathrm{mols}$ e do $\mathrm{AEAC}\left(\mathrm{C}_{2} \mathrm{H}_{5} \mathrm{OH} 0,018 \mathrm{H}_{2} \mathrm{O}\right)$ é de $46,393 \mathrm{~g} / \mathrm{mols}$, incluso o teor de água presente no AEAC.

Pode-se, então, escrever:

$$
\begin{aligned}
46,393 C & =0,2537(110,200 A+120,195 B+46,393 C) \\
120,195 B & =0,2235(110,200 A+120,195 B+46,393 C) \\
110,200 A & =0,5228(110,200 A+120,195 B+46,393 C)
\end{aligned}
$$

Chamando a massa total de combustível $(110,200 \mathrm{~A}+120,195 \mathrm{~B}+46,393 \mathrm{C})$ de $X$, obtém-se as equações 13,14 e 15:

$$
\begin{aligned}
& A=\frac{0,5228 X}{110,200}=0,004744 X \\
& B=\frac{0,2235 X}{120,195}=0,001859 X \\
& C=\frac{0,2537 X}{46,393}=0,005468 X
\end{aligned}
$$

Estabelecida a proporção acima, foram utilizados os valores $A=0,4744$, $B=0,1859$ e $C=0,5468$.

Realizando, então, o balanço da equação química, obtém-se:

$$
\begin{aligned}
& 0,4744 \mathrm{C}_{8} \mathrm{H}_{14}+0,1859 \mathrm{C}_{9} \mathrm{H}_{12}+0,5468 \mathrm{C}_{2} \mathrm{H}_{5} \mathrm{OH} 0,018 \mathrm{H}_{2} \mathrm{O}+9,3268\left(\mathrm{O}_{2}+3,76 \mathrm{~N}_{2}\right) \rightarrow \\
& 6,5619 \mathrm{CO}_{2}+6,0946 \mathrm{H}_{2} \mathrm{O}+35,0688 \mathrm{~N}_{2}
\end{aligned}
$$

Dessa maneira, a relação mássica combustivel-ar estequiométrica do combustível C-9 ( $\left.F_{C 9}\right)$ está na equação 16:

$$
F_{C g}=\frac{0,4744 \times 110,200+0,1859 \times 120,195+0,5468 \times 46,393}{9,3268 \times(31,998+3,76 \times 28,014)}=\frac{1}{12,81}=0,0781
$$




\subsubsection{Reação estequiométrica do E40}

A reação de combustão completa para o combustível E40 pode ser escrita da seguinte maneira:

$$
\begin{aligned}
& \mathrm{A} \mathrm{C}{ }_{8} \mathrm{H}_{14}+\mathrm{B} \mathrm{C}_{2} \mathrm{H}_{5} \mathrm{OHn} \mathrm{H}_{2} \mathrm{O}+\mathrm{C} \mathrm{C}_{2} \mathrm{H}_{5} \mathrm{OHn} \mathrm{H}_{2} \mathrm{O}+\mathrm{D}\left(\mathrm{O}_{2}+3,76 \mathrm{~N}_{2}\right) \longrightarrow \\
& \mathrm{E} \mathrm{CO}_{2}+\mathrm{G} \mathrm{H}_{2} \mathrm{O}+\mathrm{H} \mathrm{N}_{2}
\end{aligned}
$$

Os valores de A, B e C são definidos a partir da consideração que $60 \%$ do volume de combustível é constituído de gasolina pura (molécula média: $\mathrm{C}_{8} \mathrm{H}_{14}$ ), 25\% é constituído de $A E A C$ e os $15 \%$ restantes são $A E H C$. Os valores de $D, E, G$ e $H$ são obtidos considerando a estequiometria da reação.

$\mathrm{C}_{2} \mathrm{H}_{5} \mathrm{OHn} \mathrm{H}_{2} \mathrm{O}$ é a representação do AEAC nessa reação química e $\mathrm{C}_{2} \mathrm{H}_{5} \mathrm{OHn}$ " $\mathrm{H}_{2} \mathrm{O}$ é a representação do $\mathrm{AEHC}$.

De acordo com os certificados emitidos pelas distribuidoras de combustível, adquiridos para esse experimento, a massa específica da gasolina é $0,74 \mathrm{~kg} / \mathrm{l}$, a do álcool anidro de $0,79 \mathrm{~kg} / \mathrm{l}$. Os teores alcoólicos, em massa, do AEAC e do AEHC são, respectivamente, 99,3\% e 92,6\%, considerando o maior teor de água no AEHC.

Desta forma, a massa especifica $(\bar{\rho})$ para a mistura E40 é descrita na equação 17:

$$
\begin{gathered}
\bar{\rho}=0,60 \times 0,74+0,25 \times 0,79+0,15 \times[(0,79 \times 0,926)+(1,00 \times 0,074)] \\
\rho \equiv 0,7623 \mathrm{~kg} / /(17)
\end{gathered}
$$

Portanto, em massa, a gasolina corresponde a $58,24 \%(0,74 \times 0,60 / 0,7623)$ da massa total da mistura, o AEAC corresponde a $25,91 \%(0,79 \times 0,25 / 0,7623)$, e o AEHC tem $15,85 \%(0,8055 \times 0,15 / 0,7623)$.

A massa molecular da gasolina $\left(\mathrm{C}_{8} \mathrm{H}_{14}\right)$ é de $110,200 \mathrm{~g} / \mathrm{mols}$, do AEAC $\left(\mathrm{C}_{2} \mathrm{H}_{5} \mathrm{OH} 0,018 \mathrm{H}_{2} \mathrm{O}\right)$ é de $46,393 \mathrm{~g} / \mathrm{mols}$, incluso o teor de água presente no AEAC. $\mathrm{E}$ por último, o AEHC $\left(\mathrm{C}_{2} \mathrm{H}_{5} \mathrm{OHn} " \mathrm{H}_{2} \mathrm{O}\right)$ é de $46,069 \mathrm{~g} / \mathrm{mols}$ mais o teor de água presente no AEHC.

Dessa maneira, para determinar a massa de água, temos na equação 18:

$$
\% \text { água em massa }=\frac{n^{\prime \prime} \mathrm{H}_{2} \mathrm{O}}{\mathrm{C}_{2} \mathrm{H}_{5} \mathrm{OH}+\mathrm{n}^{\prime \prime} \mathrm{H}_{2} \mathrm{O}}
$$




$$
\begin{aligned}
0,074 & =\frac{18,015 \times n^{\prime \prime}}{46,069+18,015 \times n^{\prime \prime}} \\
n^{\prime \prime} & =0,204 \\
n^{\prime \prime} \mathrm{H}_{2} \mathrm{O} & =0,204 \times 18,015=3,675 \mathrm{~g} / \mathrm{mols}
\end{aligned}
$$

Portanto:

$$
\begin{aligned}
& 49,744 C=0,1585(110,200 A+46,393 B+49,744 C) \\
& 46,393 B=0,2591(110,200 A+46,393 B+49,744 C) \\
& 110,200 A=0,5824(110,200 A+46,393 B+49,744 C)
\end{aligned}
$$

Chamando a massa total de combustivel $(110,200 A+46,393 B+49,744 \mathrm{C})$ de $X$, obtém-se as equações 19,20 e 21 :

$$
\begin{aligned}
& A=\frac{0,5824 X}{110,200}=0,005285 X \\
& B=\frac{0,2591 X}{46,393}=0,005585 X \\
& C=\frac{0,1585 X}{49,744}=0,003186 x
\end{aligned}
$$

Estabelecida a proporção acima, foram utilizados os valores $A=0,5285$, $B=0,5585$ e $C=0,3186$.

Realizando, então, o balanço da equação química, obtém-se:

$0,5285 \mathrm{C}_{8} \mathrm{H}_{14}+0,5585 \mathrm{C}_{2} \mathrm{H}_{5} \mathrm{OHO}, 018 \mathrm{H}_{2} \mathrm{O}+0,3186 \mathrm{C}_{2} \mathrm{H}_{5} \mathrm{OHO}, 204 \mathrm{H}_{2} \mathrm{O}+8,7090\left(\mathrm{O}_{2}+3,76 \mathrm{~N}_{2}\right)$ $\rightarrow \quad 5,9822 \mathrm{CO}_{2}+6,5528 \mathrm{H}_{2} \mathrm{O}+32,746 \mathrm{~N}_{2}$

Dessa maneira, a relação mássica combustivel-ar estequiométrica da mistura $E 40\left(F_{E 40}\right)$ está na equação 22:

$$
F_{E 40}=\frac{0,5285 \times 110,200+0,5585 \times 46,393+0,3186 \times 49,744}{8,7090 \times(31,998+3,76 \times 28,014)}=\frac{1}{11,96}=0,0836
$$


4.7.4 Emissões de poluentes na potência máxima

A relação ar-combustível adimensional observada é descrita pela letra $\lambda$ (lambda), dada pela equação 23:

$$
\lambda=\frac{F_{E S T}}{F_{\text {OBS }}}
$$

O valor $F_{E S T}$ é a relação combustivel-ar teórica, calculada para os três combustíveis analisados.

Dessa forma, o fator $\lambda$ é a razão entre a relação combustível-ar teórica ( $\left.F_{E S T}\right)$ e a relação combustível-ar observada (FOBs).

O valor de $\lambda$ utilizado na análise feita a seguir é a média aritmética dos resultados desta grandeza obtidos nas três curvas levantadas para cada combustível, em uma determinada rotação de funcionamento do motor.

Considerando a rotação de potência máxima dos motores para a relação combustível-ar observada, temos os seguintes resultados para cada ensaio realizado nas Tabelas 25, 26 e 27:

Tabela 25: Valor $\lambda$ do motor E25 na rotação de potência máxima.

\begin{tabular}{cccccc}
\hline Motor E25 & Transmissão & $\begin{array}{c}\text { Rotação } \\
(\mathrm{rpm})\end{array}$ & $\mathrm{F}_{\text {EST }}$ & $\mathrm{F}_{\text {OBS }}$ & $\lambda$ \\
\hline Ensaio 1 & $5^{\text {a }}$ marcha & 8500 & 0,0787 & 0,757 & 0,104 \\
\hline Ensaio 2 & $5^{\text {a }}$ marcha & 8500 & 0,0787 & 0,781 & 0,101 \\
\hline Ensaio 3 & $5^{\text {a }}$ marcha & 8500 & 0,0787 & 0,797 & 0,099 \\
\hline Ensaio 4 & $5^{\text {a }}$ marcha & 8500 & 0,0787 & 0,799 & 0,098 \\
\hline
\end{tabular}

Tabela 26: Valor $\lambda$ do motor $C 9$ na rotação de potência máxima.

\begin{tabular}{lccccc}
\hline \hline Motor C9 & Transmissão & $\begin{array}{c}\text { Rotação } \\
(\text { rpm })\end{array}$ & $F_{\text {EST }}$ & $F_{\text {OBS }}$ & $\lambda$ \\
\hline Ensaio 1 & $5^{\text {a }}$ marcha & 8500 & 0,0787 & 0,769 & 0,102 \\
\hline Ensaio 2 & $5^{\text {a }}$ marcha & 8500 & 0,0781 & 0,758 & 0,103 \\
\hline Ensaio 3 & $5^{\text {a }}$ marcha & 8500 & 0,0781 & 0,777 & 0,100 \\
\hline Ensaio 4 & $5^{\text {a }}$ marcha & 8500 & 0,0781 & 0,787 & 0,099 \\
\hline
\end{tabular}

Tabela 27: Valor $\lambda$ do motor E40 na rotaçäo de potência máxima.

\begin{tabular}{cccccc}
\hline Motor E40 & Transmissão & $\begin{array}{c}\text { Rotação } \\
(\mathrm{r} \text { m) })\end{array}$ & $\mathrm{F}_{\text {EST }}$ & $\mathrm{F}_{\text {OBS }}$ & $\lambda$ \\
\hline Ensaio 1 & $5^{\mathrm{a}}$ marcha & 8500 & 0,0787 & 0,777 & 0,101 \\
\hline Ensaio 2 & $5^{\mathrm{a}}$ marcha & 8500 & 0,0836 & 0,906 & 0,092 \\
\hline Ensaio 3 & $5^{\mathrm{a}}$ marcha & 8500 & 0,0836 & 0,908 & 0,092 \\
\hline Ensaio 4 & $5^{\mathrm{a}}$ marcha & 8500 & 0,0836 & 0,912 & 0,092 \\
\hline
\end{tabular}


As concentrações de $\mathrm{CO}, \mathrm{CO}_{2}$ e $\mathrm{HC}$ são avaliadas a partir da vazão em massa total dos gases de escape ( $\left.\dot{\mathrm{m}}_{\mathrm{esc}}\right)$.

Dessa maneira, temos a equação 24 :

$$
\begin{aligned}
& \dot{\mathrm{m}}_{\mathrm{esc}}=\dot{\mathrm{m}}_{\mathrm{c}}+\dot{\mathrm{m}}_{\mathrm{ar}} \\
& \dot{\mathrm{m}}_{\mathrm{esc}}=\dot{\mathrm{m}}_{\mathrm{c}}+\frac{\dot{\mathrm{m}}_{\mathrm{c}}}{\lambda}
\end{aligned}
$$

Sendo $\dot{m}_{\mathrm{c}}$ a vazão em massa do combustível e a $\dot{\mathrm{m}}_{\mathrm{ar}}$, a do ar, os valores de vazão em massa do motor 1, 2 e 3 estão, respectivamente, nas Tabela 28, 29 e 30:

Tabela 28: Vazão em massa dos gases de escape do motor E25.

\begin{tabular}{lcccccc}
\hline Motor E25 & $\begin{array}{c}\text { Rotação } \\
\text { observada } \\
(\mathrm{rpm})\end{array}$ & $\begin{array}{c}\text { Velocidade } \\
\text { calculada } \\
(\mathrm{km} / \mathrm{h})\end{array}$ & $\begin{array}{c}\text { Consumo de } \\
\text { combustível } \\
\text { observado } \\
(\mathrm{l} / \mathrm{h})\end{array}$ & $\begin{array}{c}\text { Massa } \\
\text { específica } \\
\text { calculada } \\
(\mathrm{kg} / \mathrm{l})\end{array}$ & $\begin{array}{c}\text { Consumo } \\
\text { horário de } \\
\text { combustível } \\
(\mathrm{kg} / \mathrm{h})\end{array}$ & $\begin{array}{c}\text { Vazão em } \\
\text { massa } \\
\text { do escape } \\
(\mathrm{kg} / \mathrm{h})\end{array}$ \\
\hline Ensaio 1 & 8500 & 102,93 & 3,48 & 0,7525 & 2,62 & 27,84 \\
\hline Ensaio 2 & 8500 & 102,93 & 3,56 & 0,7525 & 2,68 & 29,31 \\
\hline Ensaio 3 & 8500 & 102,93 & 3,56 & 0,7525 & 2,68 & 29,84 \\
\hline Ensaio 4 & 8500 & 102,93 & 3.43 & 0.7525 & 2.58 & 28.80 \\
\hline
\end{tabular}

Tabela 29: Vazăo em massa dos gases de escape do motor C9.

\begin{tabular}{lcccccc}
\hline Motor C9 & $\begin{array}{c}\text { Rotação } \\
\text { observada } \\
(\mathrm{rpm})\end{array}$ & $\begin{array}{c}\text { Velocidade } \\
\text { calculada } \\
(\mathrm{km} / \mathrm{h})\end{array}$ & $\begin{array}{c}\text { Consumo de } \\
\text { combustivel } \\
\text { observado } \\
(\mathrm{V} / \mathrm{h})\end{array}$ & $\begin{array}{c}\text { Massa } \\
\text { específica } \\
\text { calculada } \\
(\mathrm{kg} / \mathrm{l})\end{array}$ & $\begin{array}{c}\text { Consumo } \\
\text { horário de } \\
\text { combustível } \\
(\mathrm{kg} / \mathrm{h})\end{array}$ & $\begin{array}{c}\text { Vazão em } \\
\text { massa } \\
\text { do escape } \\
(\mathrm{kg} / \mathrm{h})\end{array}$ \\
\hline Ensaio 1 & 8500 & 102,93 & 3,69 & 0,7525 & 2,78 & 29,93 \\
\hline Ensaio 2 & 8500 & 102,93 & 3,51 & 0,7785 & 2,73 & 29,25 \\
\hline Ensaio 3 & 8500 & 102,93 & 3,52 & 0,7785 & 2,74 & 29,99 \\
\hline Ensaio 4 & 8500 & 102,93 & 3,57 & 0,7785 & 2,78 & 30,80 \\
\hline
\end{tabular}

Tabela 30: Vazão em massa dos gases de escape do motor E40.

\begin{tabular}{lcccccc}
\hline Motor E40 & $\begin{array}{c}\text { Rotação } \\
\text { observada } \\
(\mathrm{rpm})\end{array}$ & $\begin{array}{c}\text { Velocidade } \\
\text { calculada } \\
(\mathrm{km} / \mathrm{h})\end{array}$ & $\begin{array}{c}\text { Consumo de } \\
\text { combustivel } \\
\text { observado } \\
(\mathrm{l} / \mathrm{h})\end{array}$ & $\begin{array}{c}\text { Massa } \\
\text { específica } \\
\text { calculada } \\
(\mathrm{kg} / \mathrm{l})\end{array}$ & $\begin{array}{c}\text { Consumo } \\
\text { horário de } \\
\text { combustivel } \\
(\mathrm{kg} / \mathrm{h})\end{array}$ & $\begin{array}{c}\text { Vazăo em } \\
\text { massa } \\
\text { do escape } \\
(\mathrm{kg} / \mathrm{h})\end{array}$ \\
\hline Ensaio 1 & 8500 & 102,93 & 3,52 & 0,7525 & 2,65 & 28,80 \\
\hline Ensaio 2 & 8500 & 102,93 & 3,50 & 0,7623 & 2,67 & 31,59 \\
\hline Ensaio 3 & 8500 & 102,93 & 3,47 & 0,7623 & 2,65 & 31,37 \\
\hline Ensaio 4 & 8500 & 102,93 & 3,45 & 0.7623 & 2,63 & 31,30 \\
\hline
\end{tabular}

A vazão em massa dos gases $\mathrm{CO}, \mathrm{CO}_{2}$ e $\mathrm{HC}$ seguem respectivamente as equações 25,26 e 27 :

$$
\text { Emissão de } \mathrm{CO}=\frac{\% \text { CO observado }}{100} \times \frac{\text { massa molar } \mathrm{CO}}{\text { massa molar } \mathrm{Ar}} \times \dot{\mathrm{m}}_{\mathrm{esc}}
$$


Emissão de $\mathrm{CO}_{2}=\frac{\% \mathrm{CO}_{2} \text { observado }}{100} \times \frac{\text { massa molar } \mathrm{CO}_{2}}{\text { massa molar } \mathrm{Ar}} \times \dot{\mathrm{m}}_{\mathrm{esc}}$

Emissão de $H C=\frac{p p m ~ H C \text { observado }}{10^{6}} \times \frac{\text { massa molar } \mathrm{HC}}{\text { massa molar } \mathrm{Ar}} \times \dot{\mathrm{m}}_{\mathrm{esc}}$

Dessa maneira, os resultados de produção de poluentes para as condições consideradas estão nas Tabelas 31, 32 e 33 para os motores 1, 2 e 3, respectivamente:

Tabela 31: Vazão em massa dos gases $\mathrm{HC}, \mathrm{CO}$ e $\mathrm{CO}_{2}$ do motor $\mathrm{E} 25$ a $8.500 \mathrm{rpm}$.

\begin{tabular}{|c|c|c|c|c|c|c|}
\hline \multirow[b]{2}{*}{ Motor E25 } & \multicolumn{3}{|c|}{ Valores observados } & \multicolumn{3}{|c|}{ Valores calculados } \\
\hline & $\begin{array}{c}\text { Emissão de } \\
\text { HC } \\
\text { (ppm) }\end{array}$ & $\begin{array}{c}\text { Emissão de } \\
\text { CO } \\
\text { (\%) }\end{array}$ & $\begin{array}{c}\text { Emissão de } \\
\mathrm{CO}_{2} \\
(\%)\end{array}$ & $\begin{array}{c}\text { Emissão de } \\
\text { HC } \\
(g / h)\end{array}$ & $\begin{array}{c}\text { Emissão de } \\
\text { CO } \\
(\mathrm{kg} / \mathrm{h})\end{array}$ & $\begin{array}{c}\text { Emissão de } \\
\mathrm{CO}_{2} \\
(\mathrm{kgh})\end{array}$ \\
\hline Ensaio 1 & 244 & 8,61 & 9,54 & 3,27 & 2,35 & 4,09 \\
\hline Ensaio 2 & 224 & 7.99 & 9,93 & 3.15 & 2.29 & 4,48 \\
\hline Ensaio 3 & 248 & 7,15 & 10,48 & 3,56 & 2,09 & 4,81 \\
\hline Ensaio 4 & 259 & 7.50 & 10.31 & 3,59 & 212 & 4.57 \\
\hline
\end{tabular}

Tabela 32: Vazão em massa dos gases $\mathrm{HC}, \mathrm{CO}$ e $\mathrm{CO}_{2}$ do motor $\mathrm{C}-9$ a $8.500 \mathrm{rpm}$.

\begin{tabular}{|c|c|c|c|c|c|c|}
\hline \multirow[b]{2}{*}{ Motor C9 } & \multicolumn{3}{|c|}{ Valores observados } & \multicolumn{3}{|c|}{ Valores calculados } \\
\hline & $\begin{array}{c}\text { Emissão de } \\
\text { HC } \\
\text { (ppm) }\end{array}$ & $\begin{array}{c}\text { Emissão de } \\
\text { CO } \\
\text { (\%) }\end{array}$ & $\begin{array}{c}\text { Emissão de } \\
\mathrm{CO}_{2} \\
(\%)\end{array}$ & $\begin{array}{c}\text { Emissão de } \\
\text { HC } \\
(g / h)\end{array}$ & $\begin{array}{c}\text { Emissão de } \\
\text { CO } \\
(\mathrm{kg} / \mathrm{h})\end{array}$ & $\begin{array}{c}\text { Emissão de } \\
\mathrm{CO}_{2} \\
(\mathrm{~kg} / \mathrm{h})\end{array}$ \\
\hline Ensaio 1 & 265 & 8,58 & 9,64 & 3,81 & 2,51 & 4,44 \\
\hline Ensaio 2 & 233 & 9.08 & 9,68 & 3.24 & 2.57 & 4,30 \\
\hline Ensaio 3 & 242 & 8,23 & 10,06 & 3,44 & 2,38 & 4,58 \\
\hline Ensaio 4 & 244 & 8.00 & 10.39 & 3.57 & 2.38 & 4.86 \\
\hline
\end{tabular}

Tabela 33: Vazão em massa dos gases $\mathrm{HC}, \mathrm{CO}$ e $\mathrm{CO}_{2}$ do motor $\mathrm{E} 40$ a $8.500 \mathrm{rpm}$.

\begin{tabular}{|c|c|c|c|c|c|c|}
\hline \multirow[b]{2}{*}{ Motor E40 } & \multicolumn{3}{|c|}{ Valores observados } & \multicolumn{3}{|c|}{ Valores calculados } \\
\hline & $\begin{array}{c}\text { Emissão de } \\
\text { HC } \\
(\mathrm{ppm})\end{array}$ & $\begin{array}{c}\text { Emissão de } \\
\text { CO } \\
\text { (\%) }\end{array}$ & $\begin{array}{c}\text { Emissão de } \\
\mathrm{CO}_{2} \\
(\%)\end{array}$ & $\begin{array}{c}\text { Emissão de } \\
\text { HC } \\
(\mathbf{g} / \mathrm{h})\end{array}$ & $\begin{array}{c}\text { Emissão de } \\
\text { CO } \\
(\mathrm{kg} / \mathrm{h})\end{array}$ & $\begin{array}{c}\text { Emissão de } \\
\mathrm{CO}_{2} \\
(\mathrm{kgh})\end{array}$ \\
\hline Ensaio 1 & 251 & 8,91 & 9,48 & 3,48 & 2,52 & 4,20 \\
\hline Ensaio 2 & 143 & 3.58 & 12.98 & 2,15 & 1.09 & 6.22 \\
\hline Ensaio 3 & 153 & 3,58 & 12,90 & 2,27 & 1,08 & 6,14 \\
\hline Ensaio 4 & 165 & 3.11 & 13.25 & 2,45 & 0.94 & 6.30 \\
\hline
\end{tabular}

Os motores analisados não têm dispositivos para a redução das emissões de poluentes como o catalisador e sistema de indução de ar, de modo que os valores observados são os efetivos. 
Na potência máxima, com a rotação do motor em 8.500 rpm, $5^{a}$ marcha acoplada, o veículo estaria a $102,93 \mathrm{~km} / \mathrm{h}$. Portanto, as emissões em gramas por quilômetro $(\mathrm{g} / \mathrm{km})$, nessas condições, estão nas Tabelas 34,35 e 36 para os motores 1,2 e 3, respectivamente:

Tabela 34: Emissäo dos gases $\mathrm{HC}, \mathrm{CO}$ e $\mathrm{CO}_{2}$ em g/km do motor E25.

\begin{tabular}{lcccccc}
\hline Motor E25 & Transmissäo & $\begin{array}{c}\text { Rotação } \\
(\mathrm{rpm})\end{array}$ & $\begin{array}{c}\text { Velocidade } \\
\text { calculada } \\
(\mathrm{km} / \mathrm{h})\end{array}$ & $\begin{array}{c}\text { Emissão de } \\
\mathrm{HC} \\
(\mathrm{g} / \mathrm{km})\end{array}$ & $\begin{array}{c}\text { Emissão de } \\
\mathrm{CO} \\
(\mathrm{g} / \mathrm{km})\end{array}$ & $\begin{array}{c}\text { Emissã̃o de } \\
\mathrm{CO}_{2} \\
(\mathrm{~g} / \mathrm{km})\end{array}$ \\
\hline Ensaio 1 & $5^{\text {a } \text { marcha }}$ & 8500 & 102,93 & 0,0313 & 22,48 & 39,14 \\
\hline Ensaio 2 & $5^{\text {a } \text { marcha }}$ & 8500 & 102,93 & 0,0302 & 21,96 & 42,89 \\
\hline Ensaio 3 & $5^{\text {a } \text { marcha }}$ & 8500 & 102,93 & 0,0340 & 20,00 & 46,08 \\
\hline Ensaio 4 & $5^{\text {a marcha }}$ & 8500 & 102,93 & 0,0344 & 20,26 & 43,77 \\
\hline
\end{tabular}

Tabela 35: Emissão dos gases $\mathrm{HC}, \mathrm{CO}$ e $\mathrm{CO}_{2}$ em g/km do motor C-9.

\begin{tabular}{|c|c|c|c|c|c|c|}
\hline Motor C9 & Transmissāo & $\begin{array}{c}\text { Rotação } \\
\text { (rpm) }\end{array}$ & $\begin{array}{c}\text { Velocidade } \\
\text { calculada } \\
(\mathrm{km} / \mathrm{h})\end{array}$ & $\begin{array}{c}\text { Emissão de } \\
\mathrm{HC} \\
(\mathrm{g} / \mathrm{km})\end{array}$ & $\begin{array}{c}\text { Emissão de } \\
\text { CO } \\
(\mathrm{g} / \mathrm{km})\end{array}$ & $\begin{array}{c}\text { Emissão de } \\
\mathrm{CO}_{2} \\
(\mathrm{~g} / \mathrm{km})\end{array}$ \\
\hline Ensaio 1 & $5^{a}$ marcha & 8500 & 102,93 & 0,0365 & 24,07 & 42,54 \\
\hline Ensaio 2 & $5^{a}$ marcha & 8500 & 102,93 & 0,0314 & 24,90 & 41,71 \\
\hline Ensaio 3 & $5^{\mathrm{a}}$ marcha & 8500 & 102,93 & 0,0334 & 23,14 & 44,48 \\
\hline Ensaio 4 & $5^{\mathrm{a}}$ marcha & 8500 & 102,93 & 0,0346 & 23,11 & 47,16 \\
\hline
\end{tabular}

Tabela 36: Emissão dos gases $\mathrm{HC}, \mathrm{CO}$ e $\mathrm{CO}_{2} \mathrm{em} \mathrm{g} / \mathrm{km}$ do motor $\mathrm{E} 40$.

\begin{tabular}{lcccccc}
\hline Motor E40 Transmissão & $\begin{array}{c}\text { Rotaçăo } \\
(\mathrm{rpm})\end{array}$ & $\begin{array}{c}\text { Velocidade } \\
\text { calculada } \\
(\mathrm{km} / \mathrm{h})\end{array}$ & $\begin{array}{c}\text { Emissäo de } \\
\mathrm{HC} \\
(\mathrm{g} / \mathrm{km})\end{array}$ & $\begin{array}{c}\text { Emissão de } \\
\mathrm{CO} \\
(\mathrm{g} / \mathrm{km})\end{array}$ & $\begin{array}{c}\text { Emissão de } \\
\mathrm{CO}_{2} \\
(\mathrm{~g} / \mathrm{km})\end{array}$ \\
\hline Ensaio 1 & $5^{\text {a }}$ marcha & 8500 & 102,93 & 0,0333 & 24,08 & 40,24 \\
\hline Ensaio 2 & $5^{\text {a } \text { marcha }}$ & 8500 & 102,93 & 0,0208 & 10,61 & 60,42 \\
\hline Ensaio 3 & $5^{\text {a } \text { marcha }}$ & 8500 & 102,93 & 0,0221 & 10,52 & 59,63 \\
\hline Ensaio 4 & $5^{\text {a marcha }}$ & 8500 & 102,93 & 0,0238 & 9,13 & 61,12 \\
\hline
\end{tabular}

Os valores em gramas por quilômetro é um comparativo dos motores analisados e não se refere aos dados de emissões de poluentes com o objetivo de homologação do produto.

\subsection{Rendimento dos motores}

O rendimento global de um motor é definido como sendo a relação entre a potência observada e a taxa de energia potencialmente liberada com a queima do combustivel disponibilizado. 
Cada grama dos combustiveis utilizados possui os seguintes conteúdos energéticos:

$\mathrm{PCl}$ gasolina pura $=43,58 \mathrm{MJ} / \mathrm{kg}$

$\mathrm{PCI} \mathrm{C-9} \mathrm{=} \mathrm{44,20} \mathrm{MJ/kg}$

$\mathrm{PCl} A E A C=28,28 \mathrm{MJ} / \mathrm{kg}$

$\mathrm{PCl} \mathrm{AEHC}=26,40 \mathrm{MJ} / \mathrm{kg}$

$\mathrm{PCl}$ E25 = PCI gasolina pura $\times$ 0,7374 + PCI AEAC $\times$ 0,2626 = 39,56 MJ/kg

$\mathrm{PCl}$ C-9 = PCl gasolina pura $\times$ 0,5228 + PCI C-9 $\times 0,2235+$ PCI AEAC $\times 0,2537=39,84$

$\mathrm{MJ} / \mathrm{kg}$

$\mathrm{PCl} E 40=\mathrm{PCl}$ gasolina pura $\times 0,5824+\mathrm{PCl} \mathrm{AEAC}_{\times} 0,2591+\mathrm{PCl} \mathrm{AEHC} \times 0,1585=$ $36,89 \mathrm{MJ} / \mathrm{kg}$

O rendimento global $\left(\eta_{g}\right)$ segue a equação 28 :

$$
\begin{aligned}
& \eta g=\frac{\text { Potência efetiva }}{\dot{\mathrm{m}}_{\mathrm{c} \times} \mathrm{PCl}} \\
& \eta \mathrm{g}=\frac{1}{\mathrm{C}_{\mathrm{e} \times \mathrm{PCl}} \mathrm{PCl}}
\end{aligned}
$$

Sendo $C_{e}$ o consumo específico do combustível.

Portanto, os rendimentos globais, considerando os rendimentos da transmissão de 0,98 entre o eixo secundário e primário e 0,98 entre o eixo primário e virabrequim, estão na Tabela 37 para o motor E25, na Tabela 38 para o motor C9 e na Tabela 39 para o motor E40:

Tabela 37: rendimento global do motor E25.

\begin{tabular}{lccccc}
\hline Motor E25 & $\begin{array}{c}\text { Rotação } \\
\text { (rpm) }\end{array}$ & $\begin{array}{c}\text { Consumo } \\
\text { especifico de } \\
\text { combustivel } \\
(\mathrm{g} / \mathrm{kWh})\end{array}$ & $\begin{array}{c}\mathrm{PCl} \\
(\mathrm{MJ} / \mathrm{kg})\end{array}$ & $\begin{array}{c}\text { Consumo } \\
\text { horário de } \\
\text { combustivel } \\
(\mathrm{kg} / \mathrm{h})\end{array}$ & $\begin{array}{c}\text { Rendimento } \\
\text { global } \eta_{\mathrm{g}}\end{array}$ \\
\hline Ensaio 1 & 8500 & 402,98 & 39,56 & 2,62 & 0,235 \\
\hline Ensaio 2 & 8500 & 409,30 & 39.56 & 2.68 & 0.232 \\
\hline Ensaio 3 & 8500 & 421,82 & 39,56 & 2,68 & 0,225 \\
\hline Ensaio 4 & 8500 & 411.75 & 39.56 & 2.58 & 0.230 \\
\hline
\end{tabular}

Tabela 38: rendimento global do motor C-9.

\begin{tabular}{lccccc}
\hline Motor C9 & $\begin{array}{c}\text { Rotação } \\
\text { (rpm) }\end{array}$ & $\begin{array}{c}\text { Consumo } \\
\text { especifico de } \\
\text { combustivel } \\
(\mathrm{g} / \mathrm{kWh})\end{array}$ & $\begin{array}{c}\mathrm{PCl} \\
(\mathrm{MJ} / \mathrm{kg})\end{array}$ & $\begin{array}{c}\text { Consumo } \\
\text { horário de } \\
\text { combustível } \\
(\mathrm{kg} / \mathrm{h})\end{array}$ & $\begin{array}{c}\text { Rendimento } \\
\text { global } \eta_{\mathrm{g}}\end{array}$ \\
\hline Ensaio 1 & 8500 & 416,97 & 39,56 & 2,78 & 0,227 \\
\hline Ensaio 2 & 8500 & 422.67 & 39.84 & 2.73 & 0.223 \\
\hline Ensaio 3 & 8500 & 436,58 & 39,84 & 2,74 & 0,216 \\
\hline Ensaio 4 & 8500 & 437.50 & 39.84 & 2.78 & 0.215 \\
\hline
\end{tabular}


Tabela 39: rendimento global do motor E40.

\begin{tabular}{lccccc}
\hline Motor E40 & $\begin{array}{c}\text { Rotação } \\
(\mathrm{rpm})\end{array}$ & $\begin{array}{c}\text { Consumo } \\
\text { especifico de } \\
\text { combustível } \\
(\mathrm{g} / \mathrm{kWh})\end{array}$ & $\begin{array}{c}\mathrm{PCl} \\
(\mathrm{MJ} / \mathrm{kg})\end{array}$ & $\begin{array}{c}\text { Consumo } \\
\text { horário de } \\
\text { combustivel } \\
(\mathrm{kg} / \mathrm{h})\end{array}$ & $\begin{array}{c}\text { Rendimento } \\
\text { global } \eta_{\mathrm{g}}\end{array}$ \\
\hline Ensaio 1 & 8500 & 406,49 & 39,56 & 2,65 & 0,233 \\
\hline Ensaio 2 & 8500 & 415.34 & 36,89 & 2.67 & 0.245 \\
\hline Ensaio 3 & 8500 & 429,54 & 36,89 & 2,65 & 0,237 \\
\hline Ensaio 4 & 8500 & 438.18 & 36,89 & 2.63 & 0.232 \\
\hline
\end{tabular}

A partir da análise da evolução dos rendimentos dos motores observa-se que a menor variação ocorreu para o motor funcionando com E25; a maior redução de rendimento ocorreu para o motor que consumiu E40, conforme o Gráfico 21.

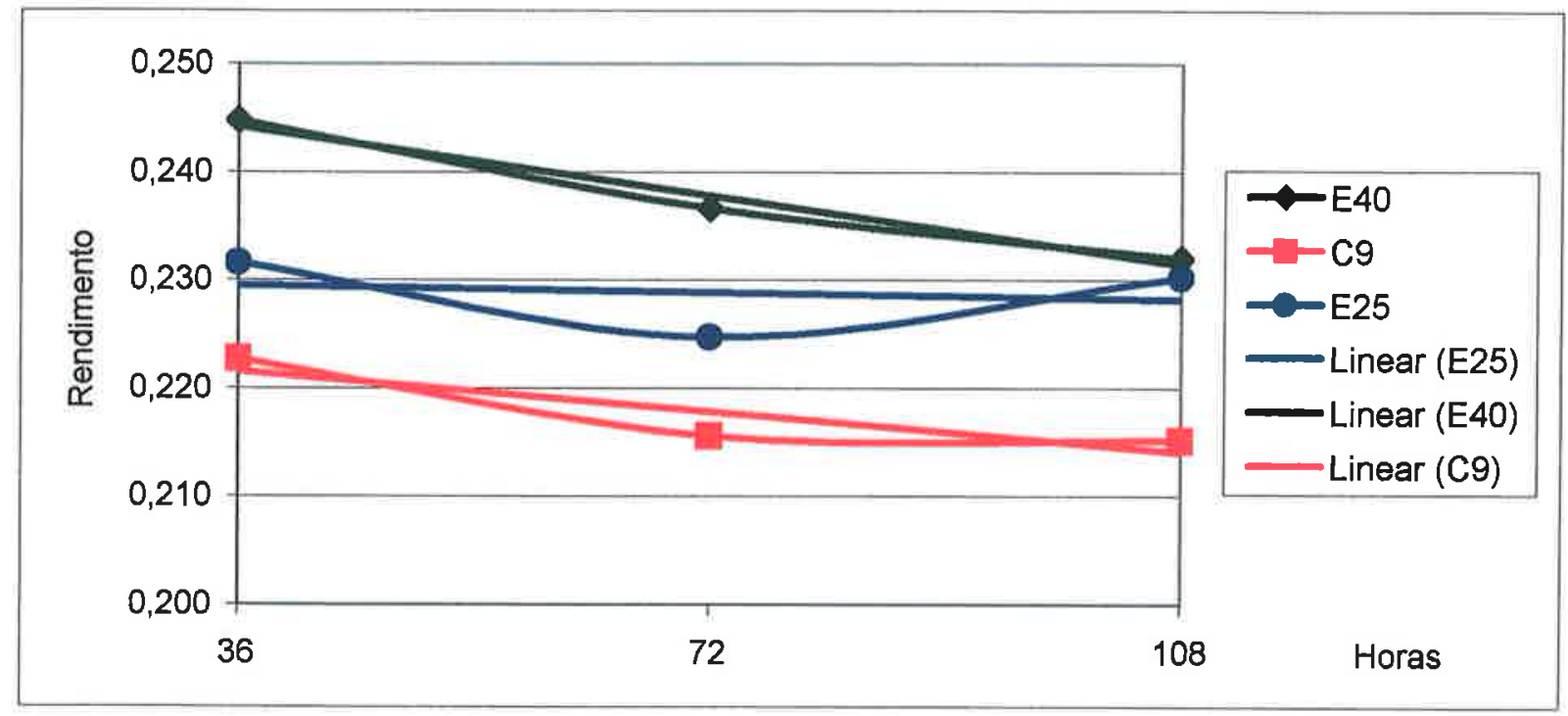

Gráfico 21: Rendimento dos motores na potência máxima.

\subsection{Análise do óleo lubrificante}

A cada ciclo foram retiradas três amostras de óleo, uma aos dez minutos de durabilidade, a segunda com 18 horas e a última com 36 horas. Na finalização do ciclo, o óleo era substituído por um novo de mesma especificação e lote de produção.

\subsubsection{Viscosidade do óleo lubrificante}

A evolução da viscosidade do óleo ao longo do experimento pode ser vista no gráfico abaixo.

As cargas de óleo não apresentaram mudanças significativas quanto à viscosidade. Uma pequena queda na viscosidade a $40^{\circ} \mathrm{cSt}$ no primeiro ciclo foi identificada no motor com combustível C-9, porém, para o período de troca 
estabelecido, não houve alterações que pudessem ser associadas a uma adulteração de combustível, de acordo com o Gráfico 22.

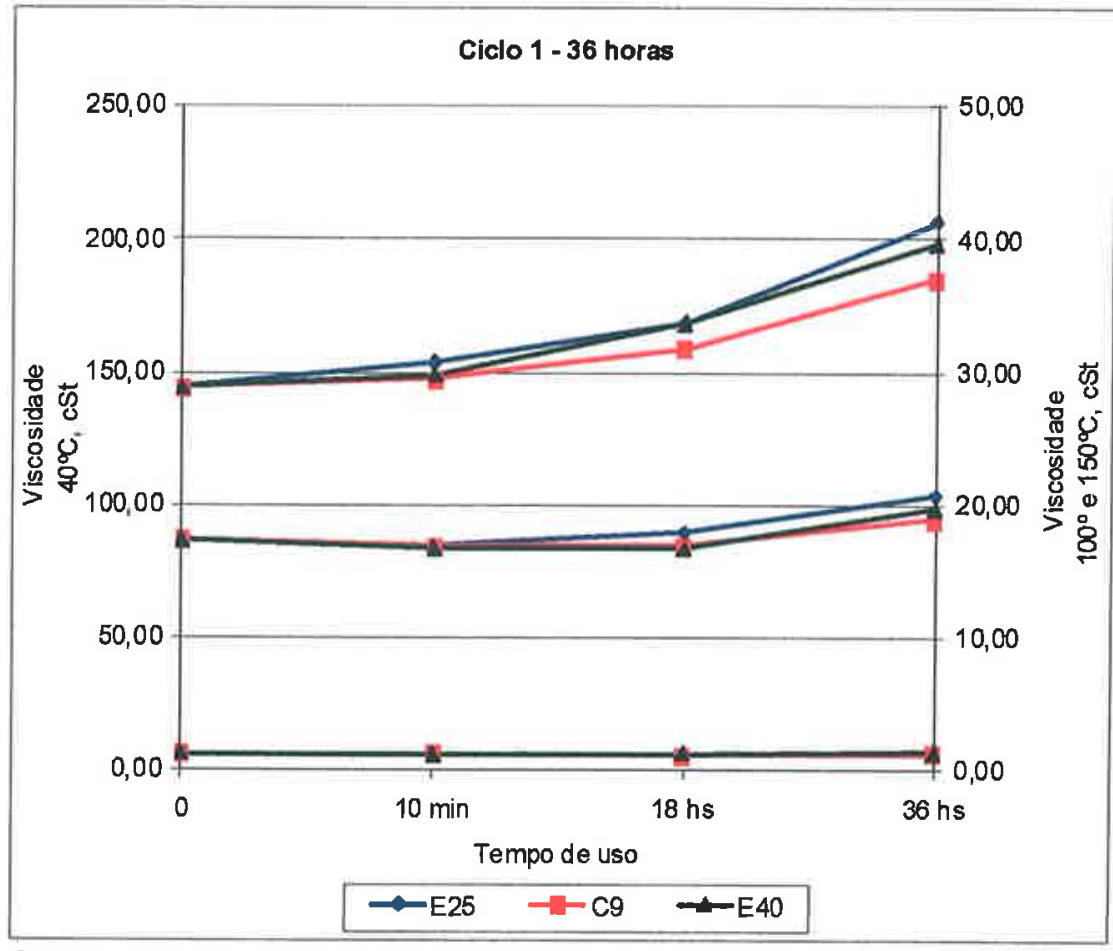

Gráfico 22: Viscosidade do óleo lubrificante nos três motores durante o primeiro ciclo.

Durante o ciclo 2 e 3 , todos os motores tiveram as viscosidade mantidas nas amostras avaliadas, conforme os Gráficos 23 e 24.

Os valores de viscosidade a $100^{\circ} \mathrm{C}$ e $150^{\circ} \mathrm{C}$ praticamente não tiveram alteração.

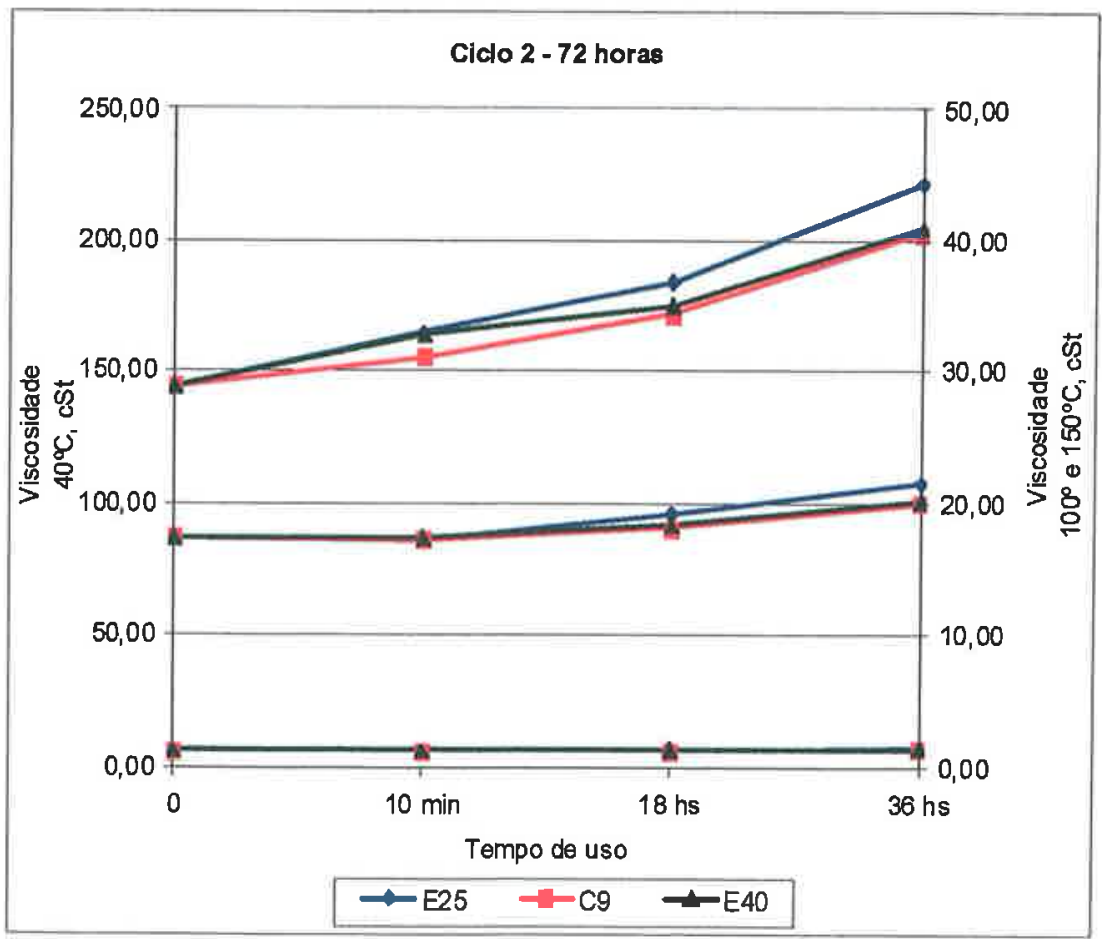

Gráfico 23: Viscosidade do óleo lubrificante nos três motores durante o segundo ciclo. 


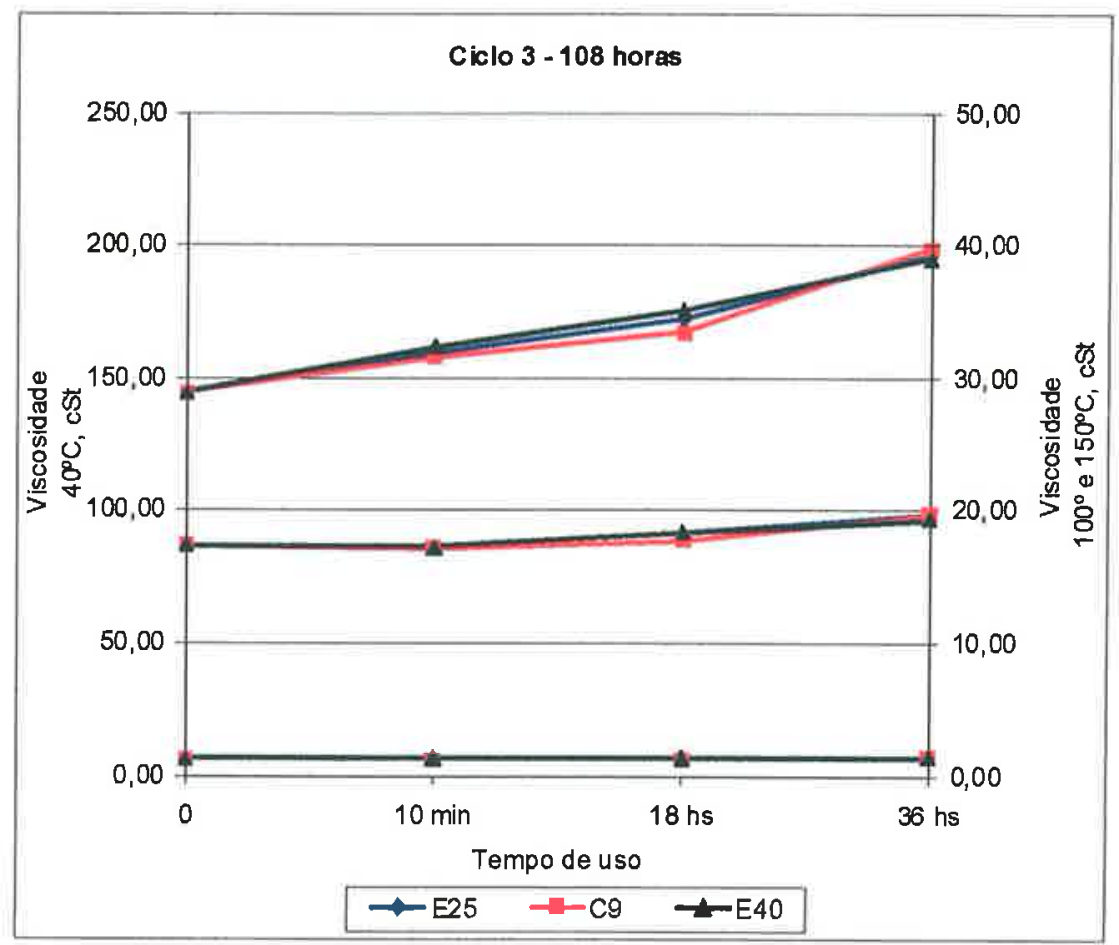

Gráfico 24: Viscosidade do óleo lubrificante nos três motores durante o terceiro ciclo.

4.9.2 Índice de viscosidade do óleo lubrificante

Os índices de viscosidade dos três motores seguiram as mesmas tendências nos três ciclos. $O$ motor 1 foi 0 que teve menor variação do índice de viscosidade, porém a diferença entre os motores não identifica a utilização de combustíveis adulterados dentro do período de troca estabelecida conforme apresentado no Gráfico 25 para o Ciclo 1, no Gráfico 26 para o Ciclo 2 e no Gráfico 27 para o Ciclo 3.

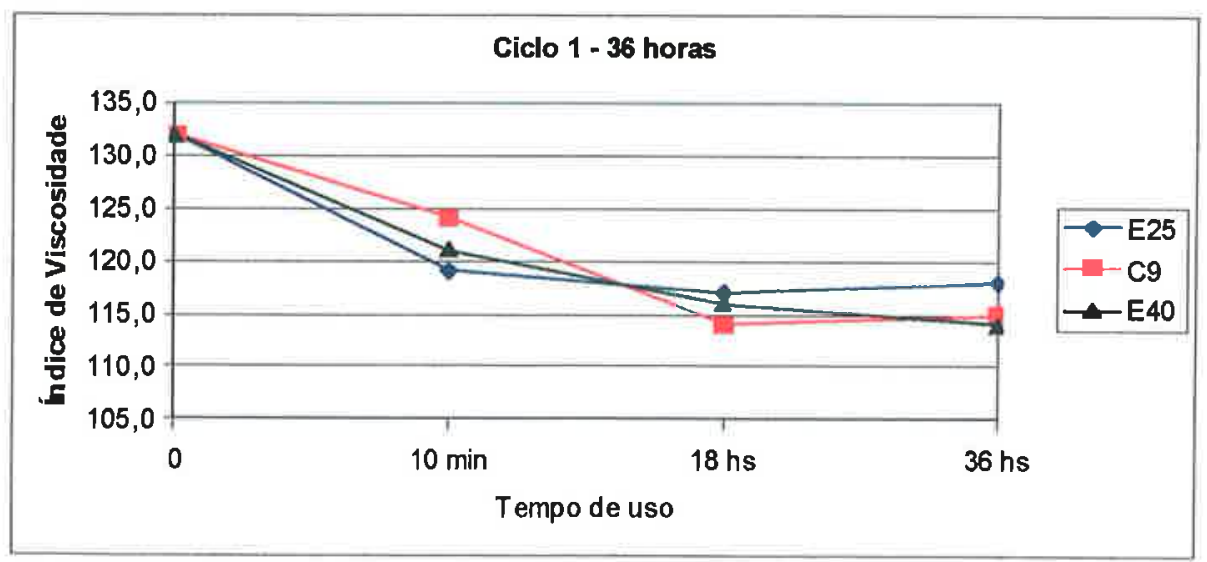

Gráfico 25: Índice de viscosidade do óleo lubrificante nos três motores durante o primeiro ciclo. 


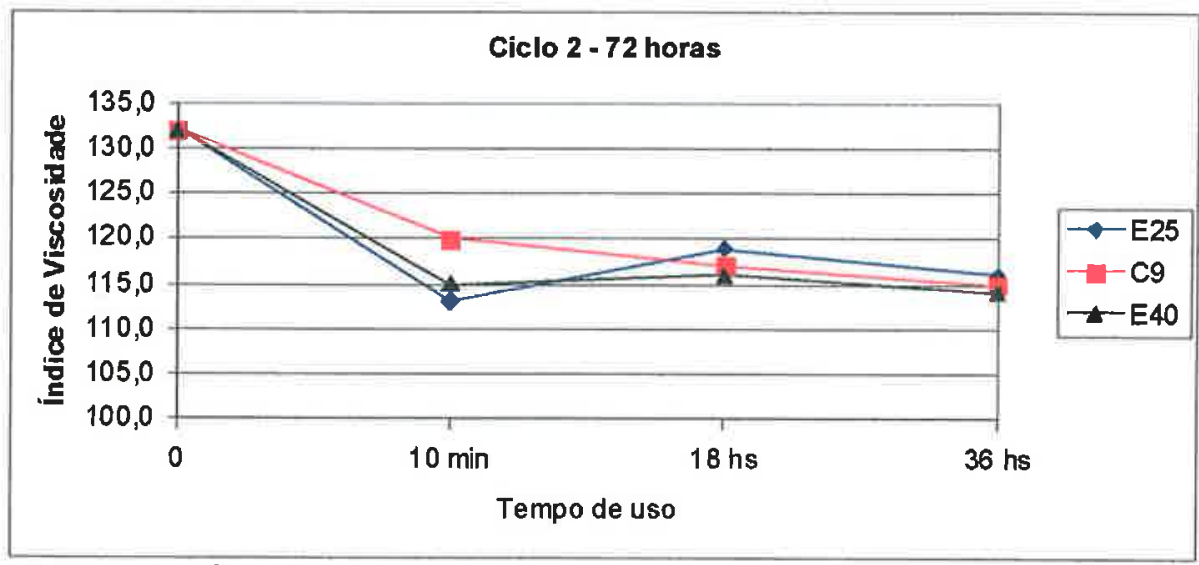

Gráfico 26: Índice de viscosidade do óleo lubrificante nos três motores durante o segundo ciclo.

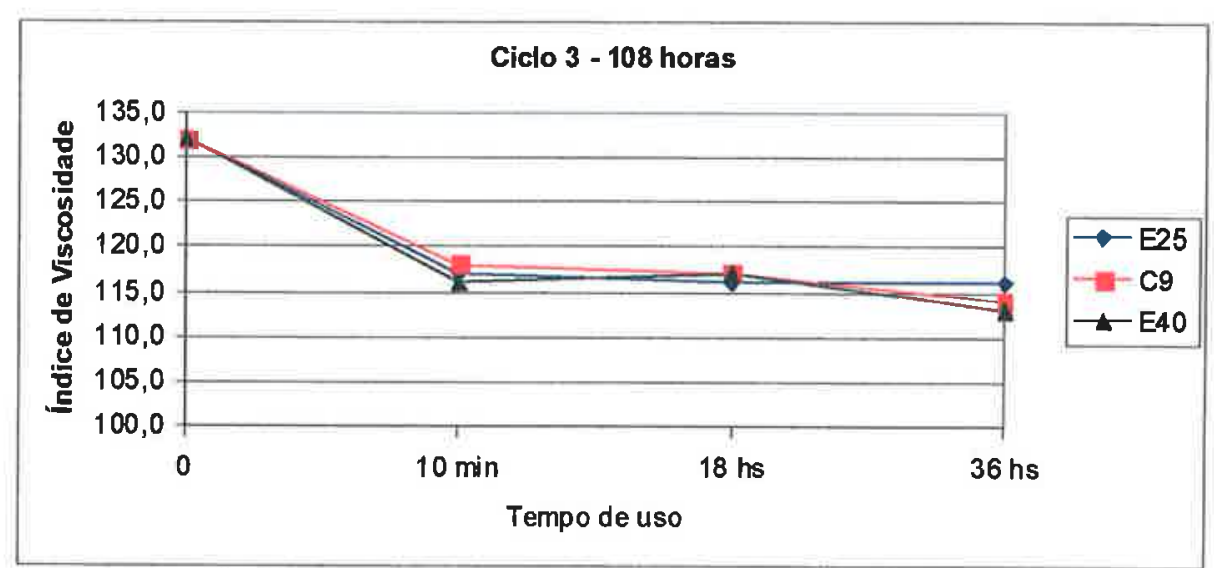

Gráfico 27: Índice de viscosidade do óleo lubrificante nos três motores durante o terceiro ciclo.

\subsubsection{Número de basicidade e acidez total}

A variação do número de basicidade e acidez total não apresentaram desvios que pudessem identificar os combustiveis utilizados nos experimentos. Devido à semelhança de cada ciclo, apenas para o último ciclo foram apresentados os números de basicidade total (Gráfico 28) e de acidez total (Gráfico 29).

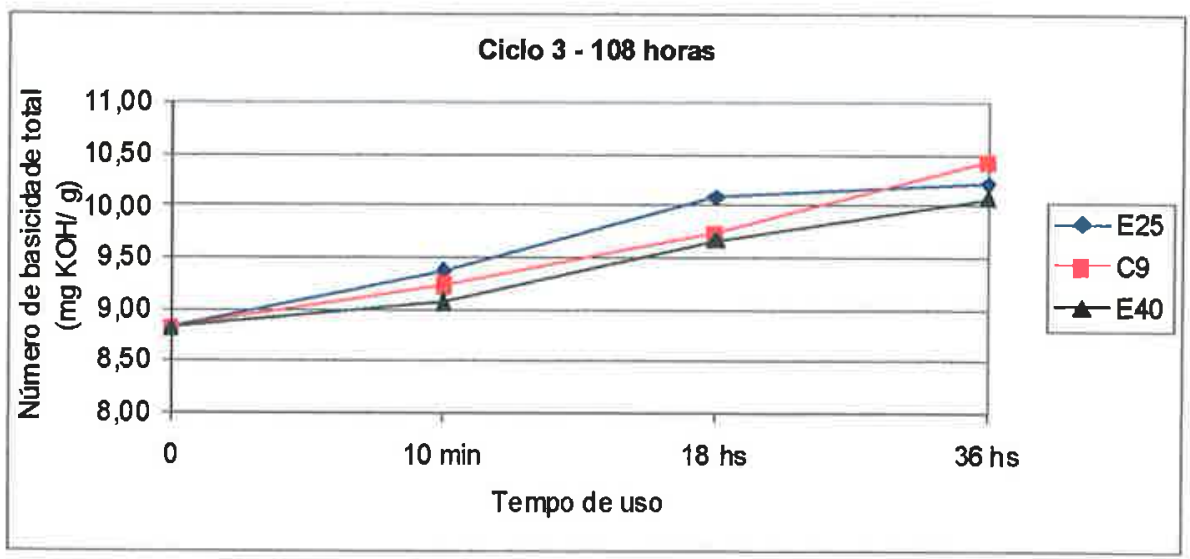

Gráfico 28: Número de basicidade total nos três motores durante o terceiro ciclo ( $\mathrm{mg} \mathrm{KOH} / \mathrm{g}$ ). 


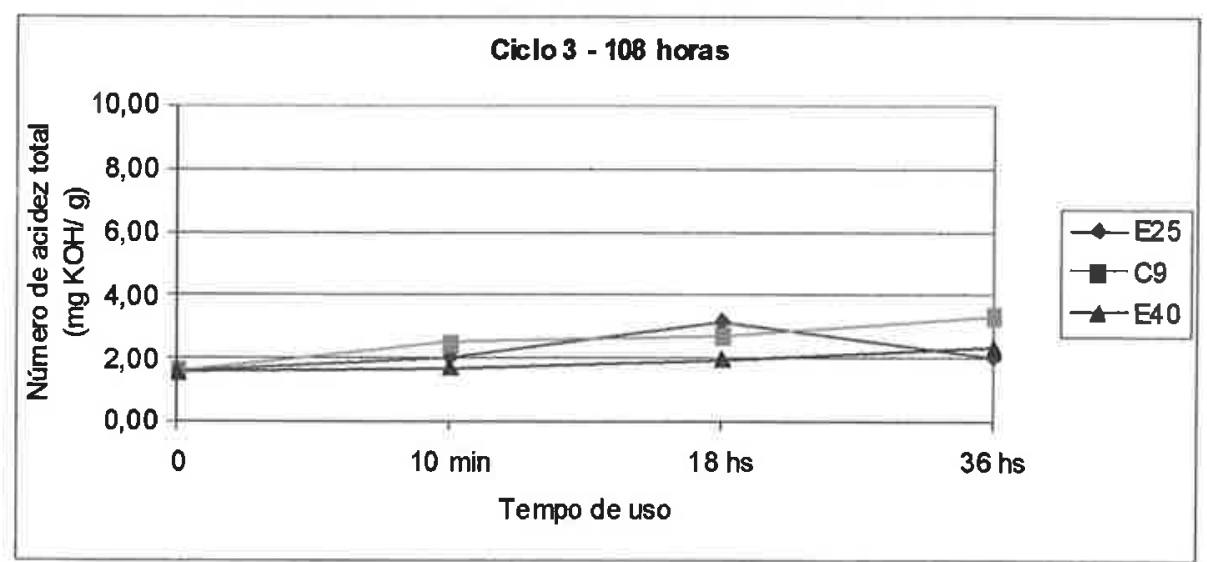

Gráfico 29: Número de acidez total nos três motores durante o terceiro ciclo (mg KOH/g).

Especificamente o motor E25, primeiro motor rodado no experimento, teve uma coleta de óleo em uma quantidade superior que foi devidamente reposta de modo que não foram observadas variações significativas tanto na basicidade quanto na acidez entre 18 e 36 horas.

\subsubsection{Concentrações de metais nos óleos lubrificantes usados}

Assim como os números de basicidade e acidez total, as concentrações em ppm de alumínio, ferro e cobre do desgaste dos motores ao longo dos experimentos foram similares.

Dessa maneira, os motores se mostraram resistentes e duráveis mesmo com a utilização de combustíveis adulterados.

Como os gráficos seguem os mesmos padrões de desgastes nos três ciclos, optou-se por apresentar apenas os Gráficos 30, 31 e 32 com o Ciclo 3.

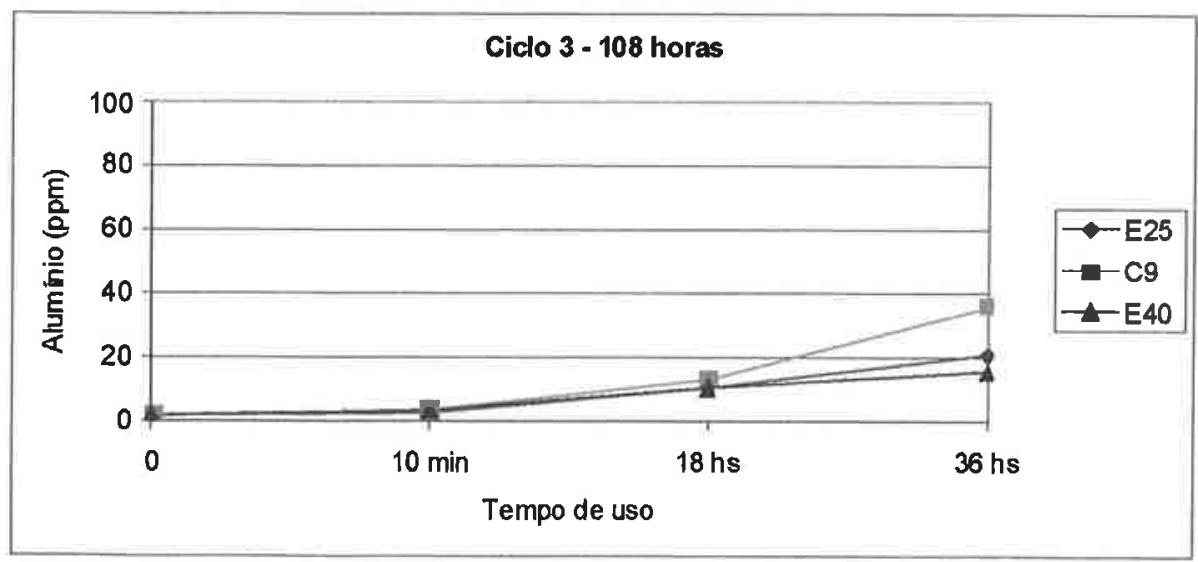

Gráfico 30: Número em ppm de alumínio encontrado nos três motores durante o terceiro ciclo. 


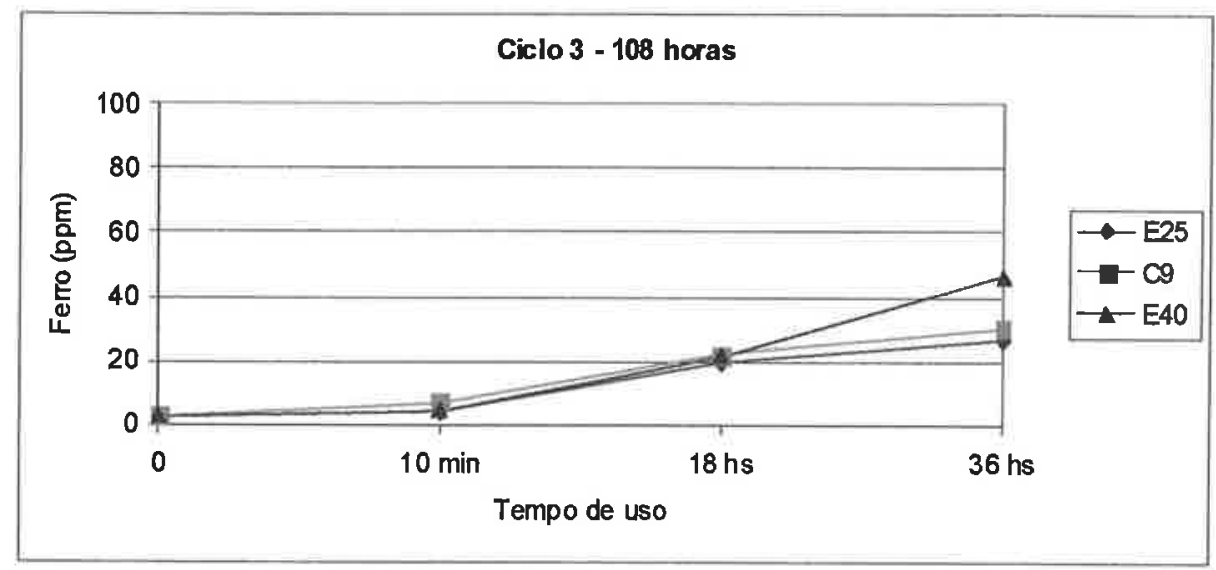

Gráfico 31: Número em ppm de ferro encontrado nos três motores durante o terceiro ciclo.

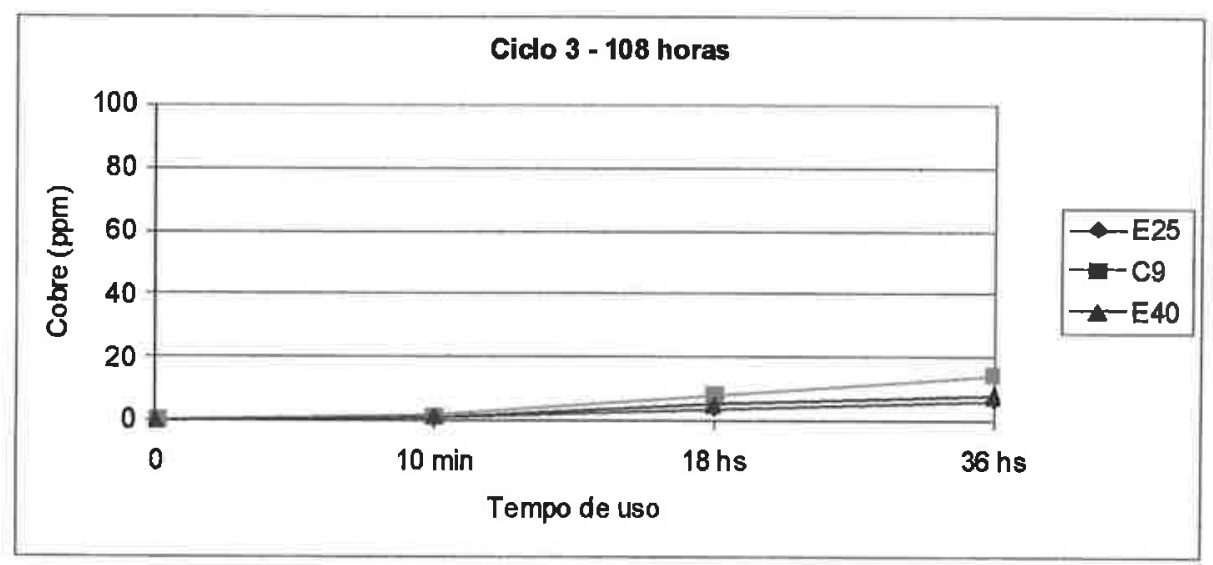

Gráfico 32: Número em ppm de cobre encontrado nos três motores durante o terceiro ciclo.

\subsubsection{Concentração de silício no óleo lubrificante usado}

A concentração de silício no óleo lubrificante usado está associada à concentração de partículas de sílica em suspensão que contaminam 0 ar consumido pelo motor. Os Gráficos 33, 34 e 35 apresentam, respectivamente, os ciclos 1, 2 e 3 .

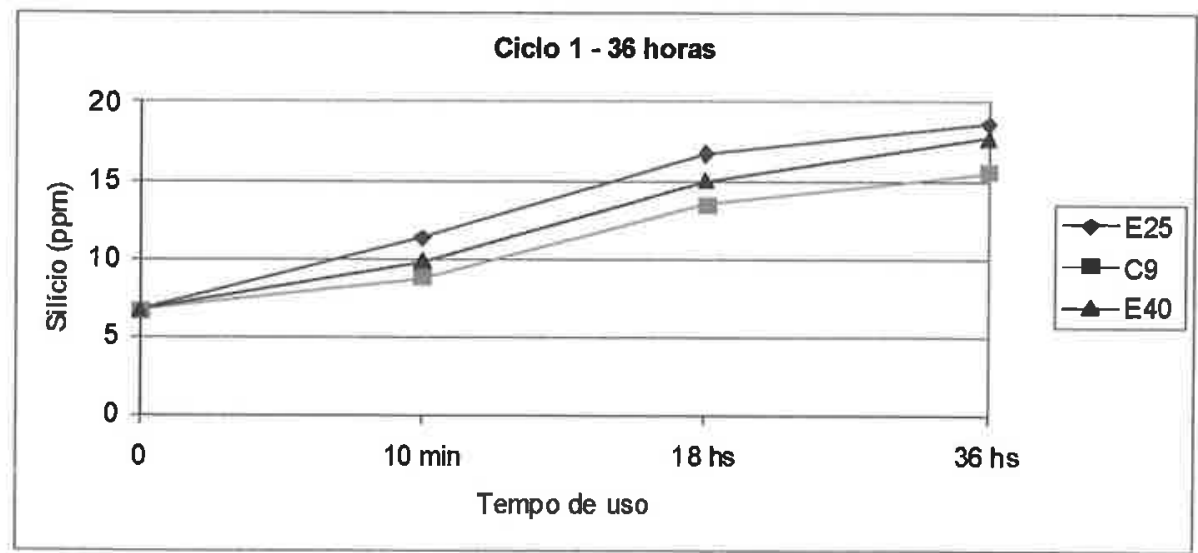

Gráfico 33: Número em ppm de silício encontrado nos três motores durante o primeiro ciclo. 


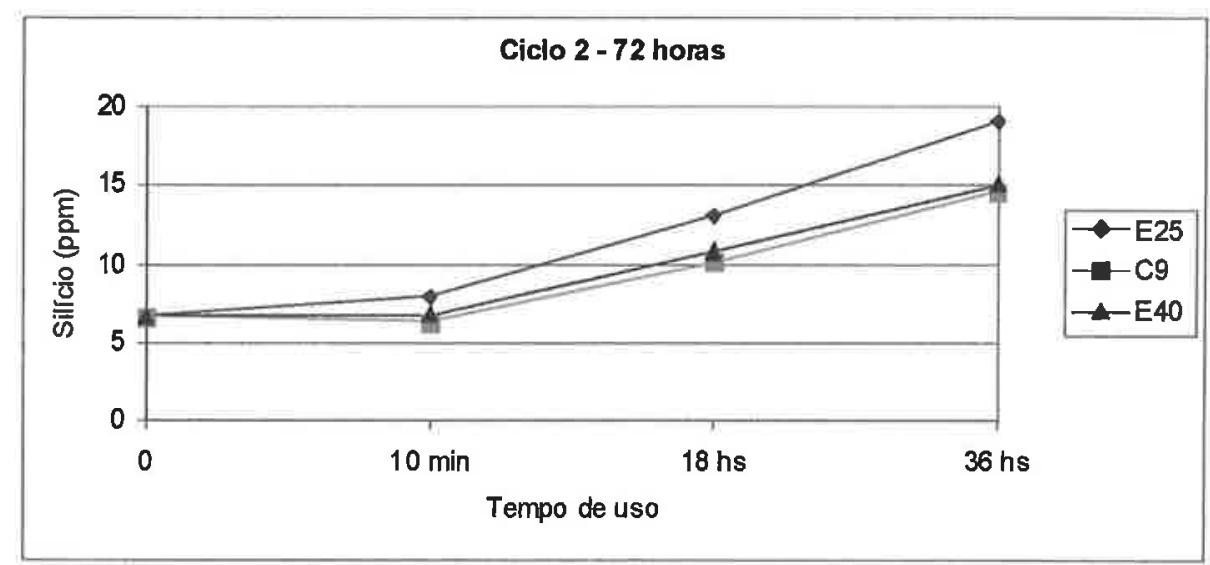

Gráfico 34: Número em ppm de silício encontrado nos três motores durante o segundo ciclo.

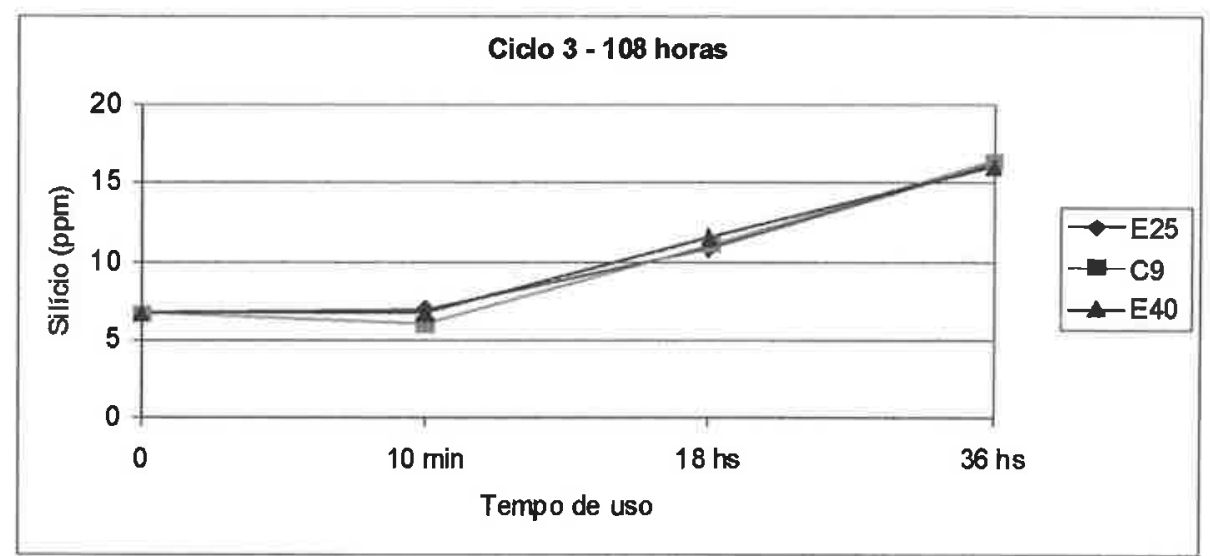

Gráfico 35: Número em ppm de silício encontrado nos três motores durante o terceiro ciclo.

Dessa maneira, pôde-se comprovar que o local onde foram realizados os experimentos era suficientemente limpo.

\subsubsection{Oxidação, nitração e presença de sulfatos do óleo lubrificante}

A oxidação mostrou ser o fenômeno mais significativo para a identificação na utilização de um combustível adulterado com a adição do solvente C-9, conforme os Gráficos 36, 37 e 38.

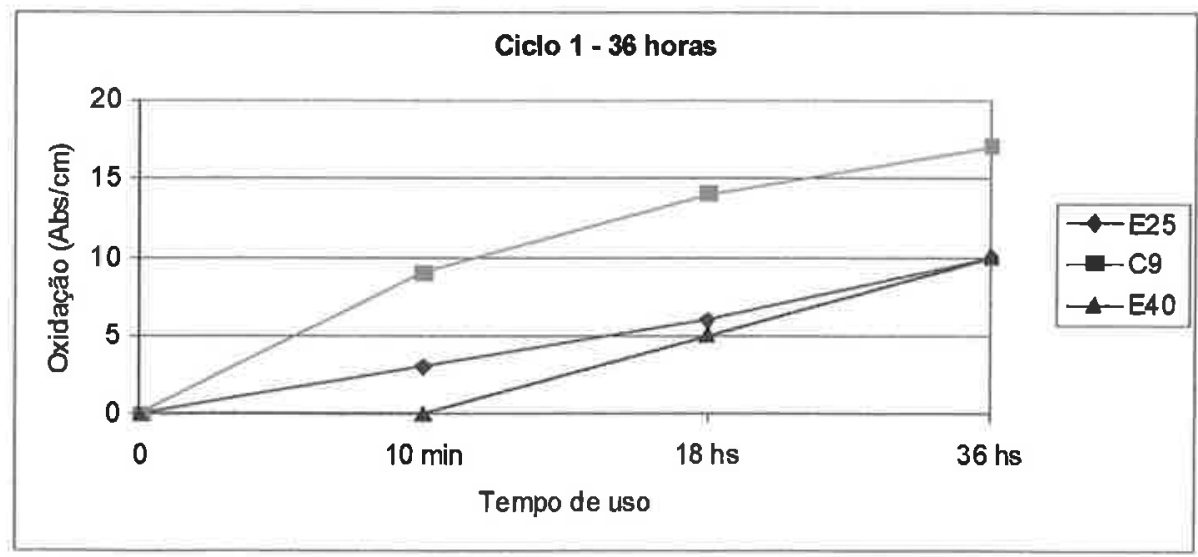

Gráfico 36: Oxidação do óleo lubrificante encontrado nos três motores durante o primeiro ciclo em $\mathrm{Abs} / \mathrm{cm}$. 


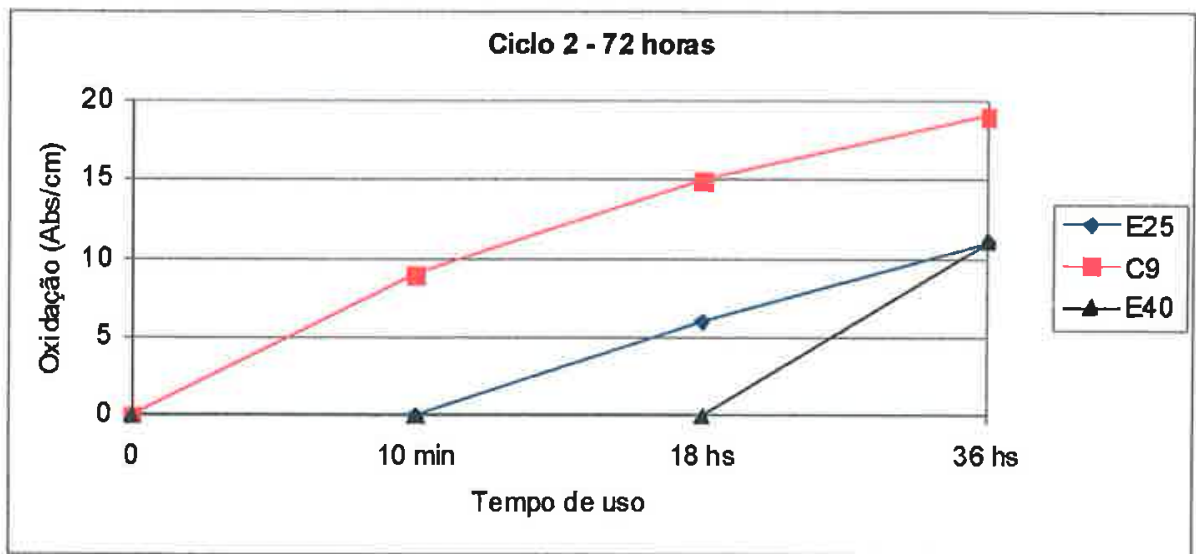

Gráfico 37: Oxidação do óleo lubrificante encontrado nos três motores durante o segundo ciclo em $\mathrm{Abs} / \mathrm{cm}$.

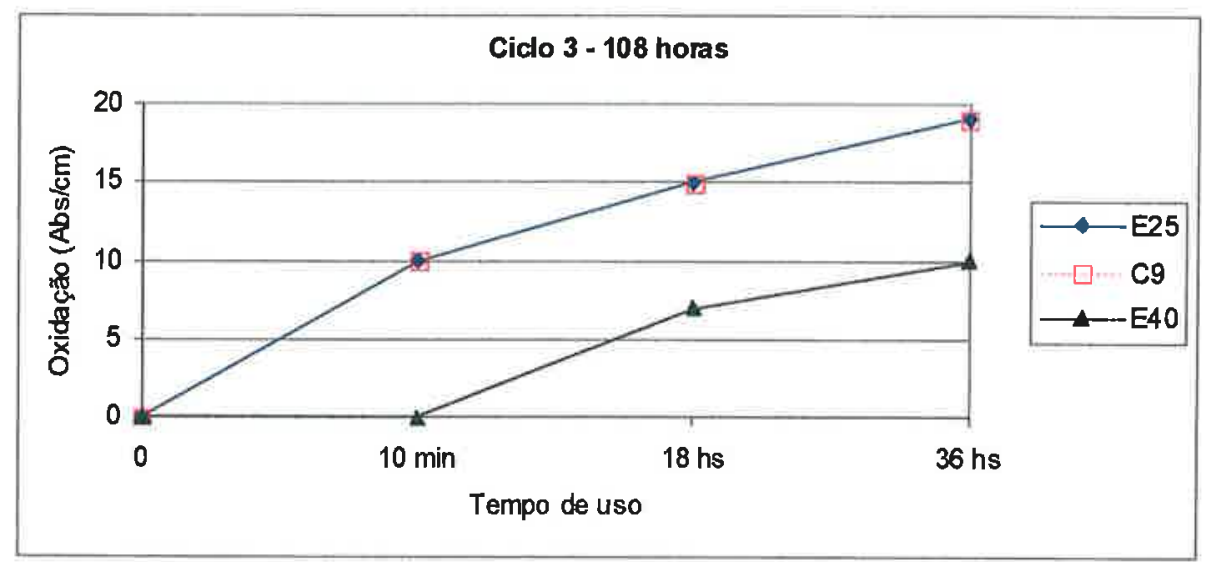

Gráfico 38: Oxidação do óleo lubrificante encontrado nos três motores durante o terceiro ciclo em Abs/ cm.

Enquanto as medidas de oxidação dos óleos utilizados nos motores E25 e E40 foram de $10 \mathrm{Abs} / \mathrm{cm}$ nos dois primeiros ciclos, o motor 2 apresentou os valores de $17 \mathrm{Abs} / \mathrm{cm}$ no primeiro ciclo e $19 \mathrm{Abs} / \mathrm{cm}$ no segundo.

No terceiro ciclo, tanto o motor E25 como o motor C-9 tiveram a mesma oxidação de $19 \mathrm{Abs} / \mathrm{cm}$.

Ao contrário dos valores de oxidação, os valores de nitração e sulfatos não se identificam os motores que operaram com os combustíveis adulterados. O Gráfico 39 apresenta o último ciclo de nitração e o Gráfico 40 apresenta o último ciclo na presença de sulfatos.

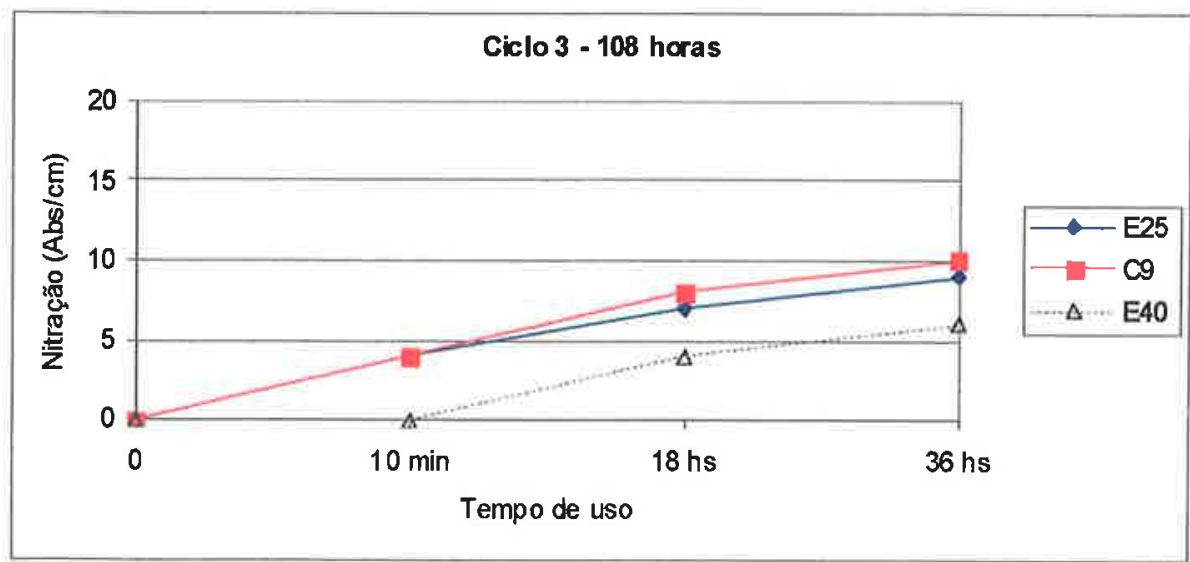

Gráfico 39: Nitraçāo do óleo lubrificante encontrado nos três motores durante o terceiro ciclo em Abs/ cm. 
Por isso, como os resultados de nitração e presença de sulfatos nos óleos são semelhantes, optou- se por apresentar somente o terceiro ciclo.

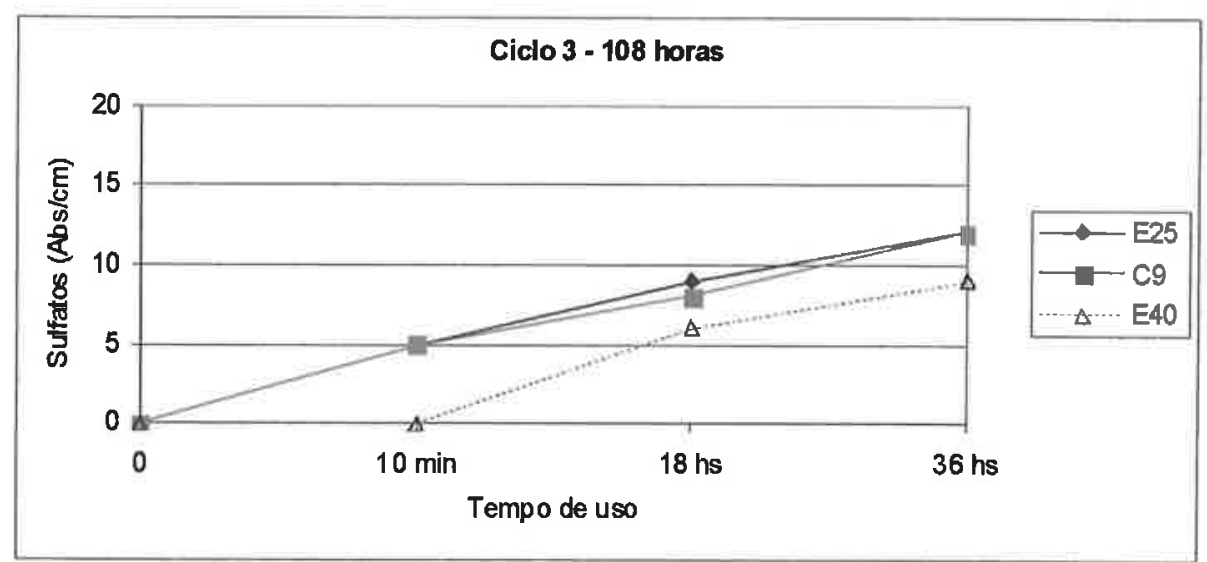

Gráfico 40: Presença de sulfatos do óleo lubrificante encontrado nos três motores durante o terceiro ciclo em $\mathrm{Abs} / \mathrm{cm}$.

4.10 Análise visual das principais peças

A análise visual é essencial na identificação da adulteração. Os depósitos em pistões, anéis e velas de ignição se diferenciaram nas características entre os motores testados.

As principais peças são aquelas que tiveram contato direto com 0 combustível testado e conseqüentemente são afetadas de forma a apresentarem mais nitidamente os efeitos causados pelas diferentes misturas.

As válvulas tiveram os acúmulos de goma semelhantes entre o motor E25 e motor C-9. O motor que usou E40 teve menor acúmulo de goma, justificada pela adição de AEHC.

A haste da válvula do motor E40 teve o depósito de goma mais concentrado, enquanto os motores E25 e C-9 tiveram depósitos mais porosos.

A adição do solvente C-9 no motor 2, apesar da maior quantidade de hidrocarbonetos aromáticos, teve quantidade e característica do acúmulo de goma semelhantes à observada no motor que operou com E25.

As válvulas de escape não tiveram acúmulo de goma. Os motores que utilizaram E25 e C-9 apresentam depósitos semelhantes em termos de coloração e o motor E40 apresentou uma tonalidade mais clara, decorrente da adição do AEHC. 


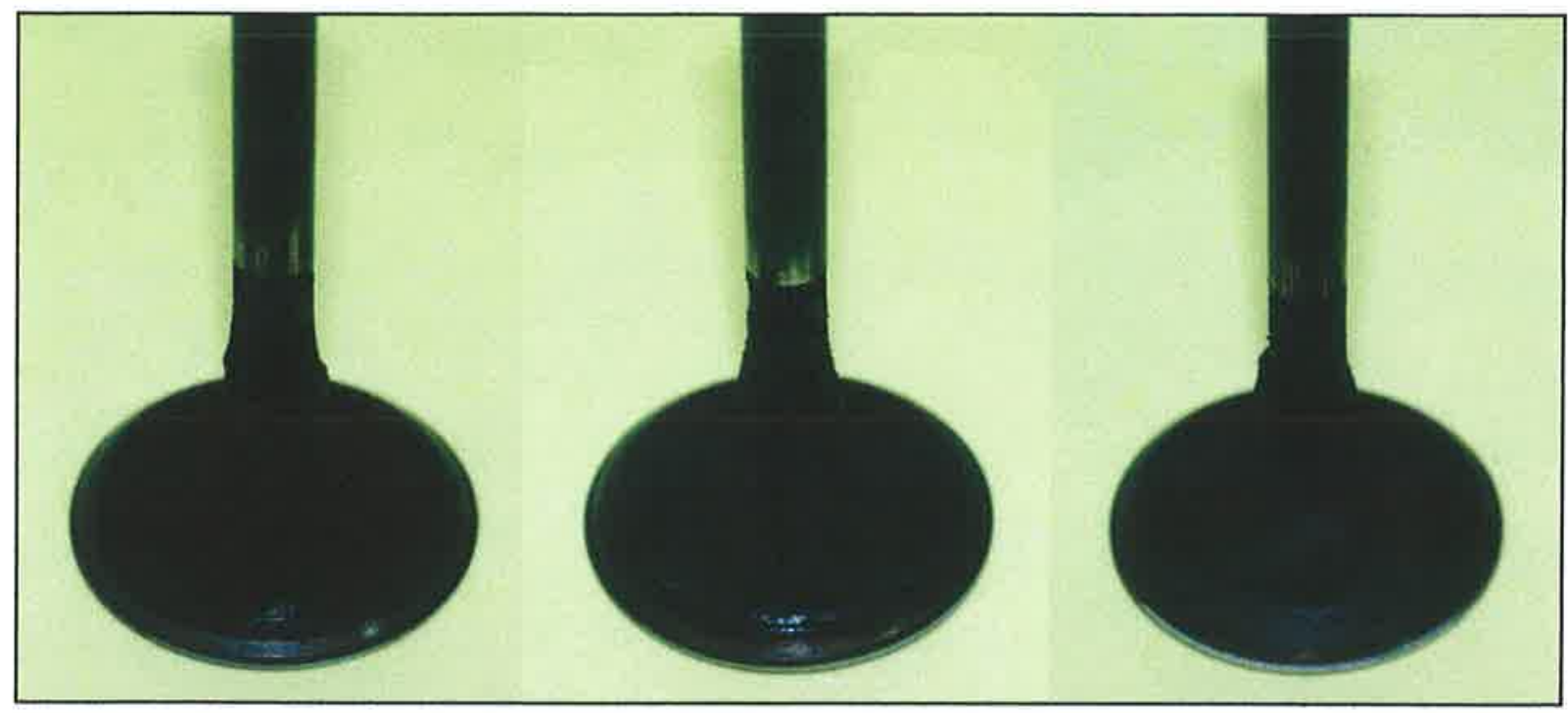

Figura 12: Válvulas de admissão do motor E25 (esquerda), motor C-9 (centro) e motor E40 (direita).

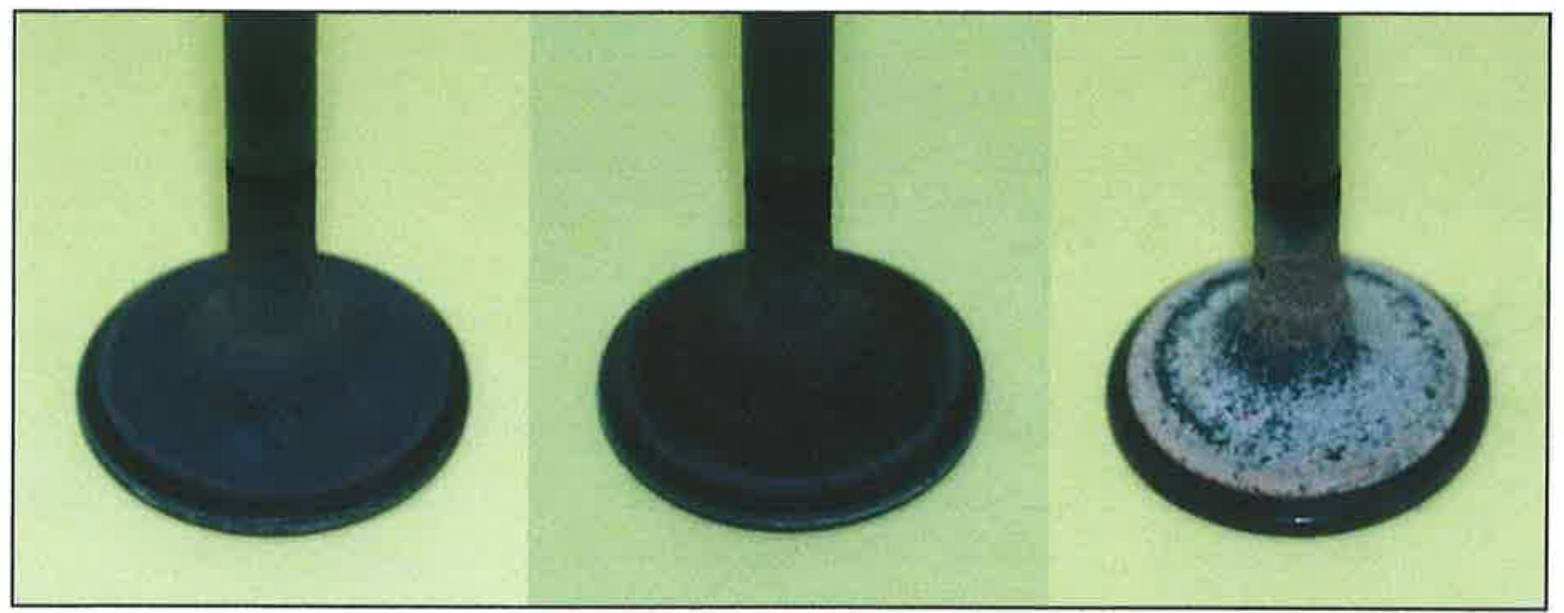

Figura 13: Válvulas de escape do motor E25 (esquerda), motor C-9 (centro) e motor E40 (direita).

As câmaras de combustão não apresentaram depósitos de carvão. Houve tonalidades diferentes em relação ao combustível testado. O motor E25 apresentou uma tonalidade intermediária entre o motor E40, mais clara, e o motor C-9, mais escura.

Isso se deve ao fato do motor que usou E40 ter trabalhado com mistura mais pobre que os demais. O motor C-9, mesmo trabalhando com uma mistura combustívelar próxima à do E25, apresentou-se mais carbonizado devido à concentração do solvente C-9.

Nota-se que todas as câmaras de combustão, principalmente do E40, apresentam coloração mais escura do lado oposto a vela de ignição. Isso se deve à ocorrência de combustão menos intensa nessa área.

O motor E25 apresenta uma camada carbonizada na câmara de combustão superior ao C-9, decorrente, provavelmente, pelo número de octano superior ao E25. 


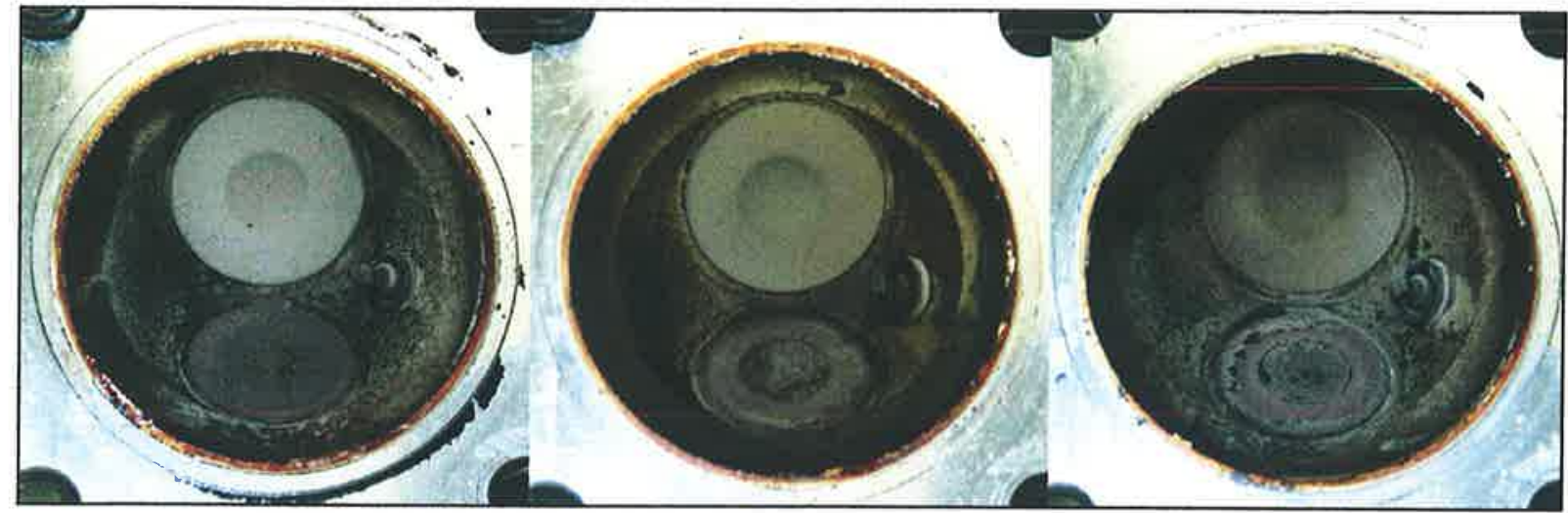

Figura 14: Câmara de combustão do motor E25 (esquerda), motor C-9 (centro) e motor E40 (direita).

Entretanto, nos pistões são mais nítidas as diferenças entre os depósitos, considerando os combustíveis utilizados.

A coloração mais clara e uniforme em toda parte superior do pistão do motor E25 mostra que a mistura combustível-ar era mais próxima da ideal.

Em contra partida, a tonalidade escura na parte superior do pistão do motor C-9 evidencia que a frente de chama é mais lenta que a estabelecida no motor usando E25, pela maior concentração de moléculas de nove átomos de carbono nessa mistura relativamente ao E25 e E40.

Já no motor E40, encontram-se áreas carbonizadas opostas à vela de ignição, no sentido da válvula de admissão para o escape, que mostra o efeito da maior velocidade da frente de chama nesses locais, o que faz a carbonização ser mais intensa nessa área.

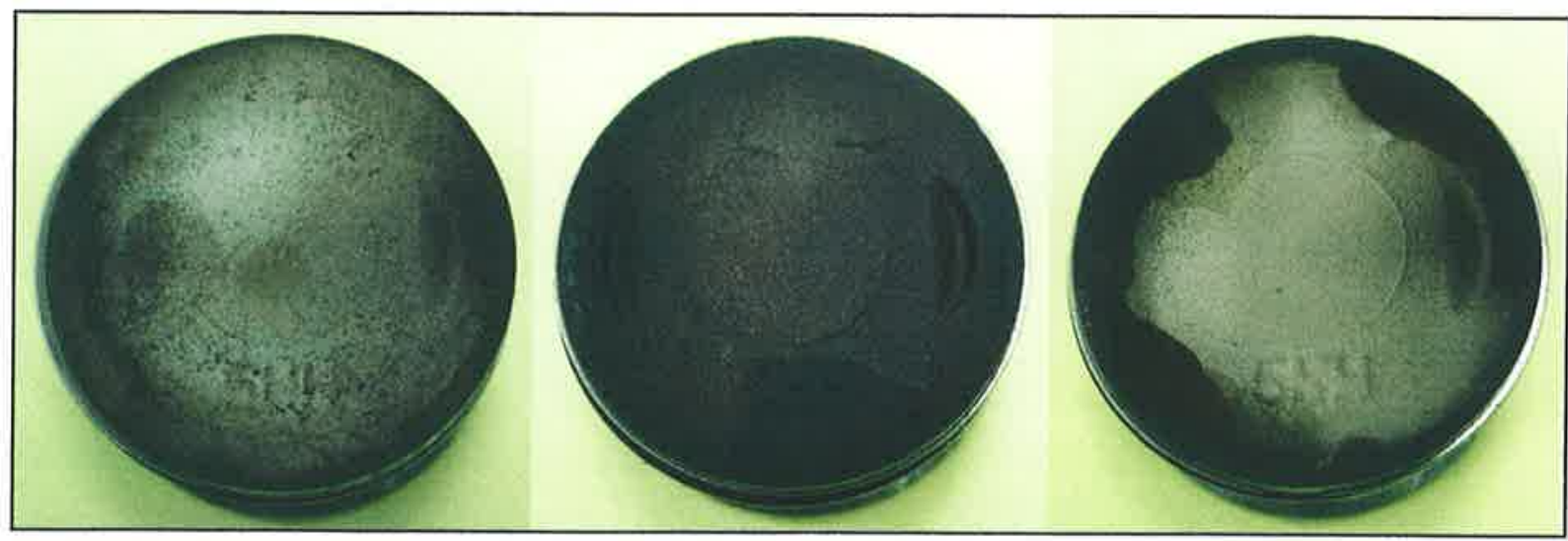

Figura 15: Vista superior do pistão do motor E25 (esquerda), motor C-9 (centro) e motor E40 (direita).

$\mathrm{Na}$ análise lateral, verifica-se que a posição dos anéis estavam corretas e as maiores perdas dos gases são evidenciados nos anéis de compressão do motor E40. 
A concentração maior de álcool combustível no motor E40 dificultou a lubrificação do cilindro e conseqüentemente aumentou o desgaste dos anéis, principalmente o segundo anel de compressão.

Essa situação foi evidenciada devido ao maior desgaste do segundo anel com a perda do tratamento superficial. Além disso, há uma tonalidade escura na lateral decorrente dos gases de escape que foram para o cárter após a combustão.

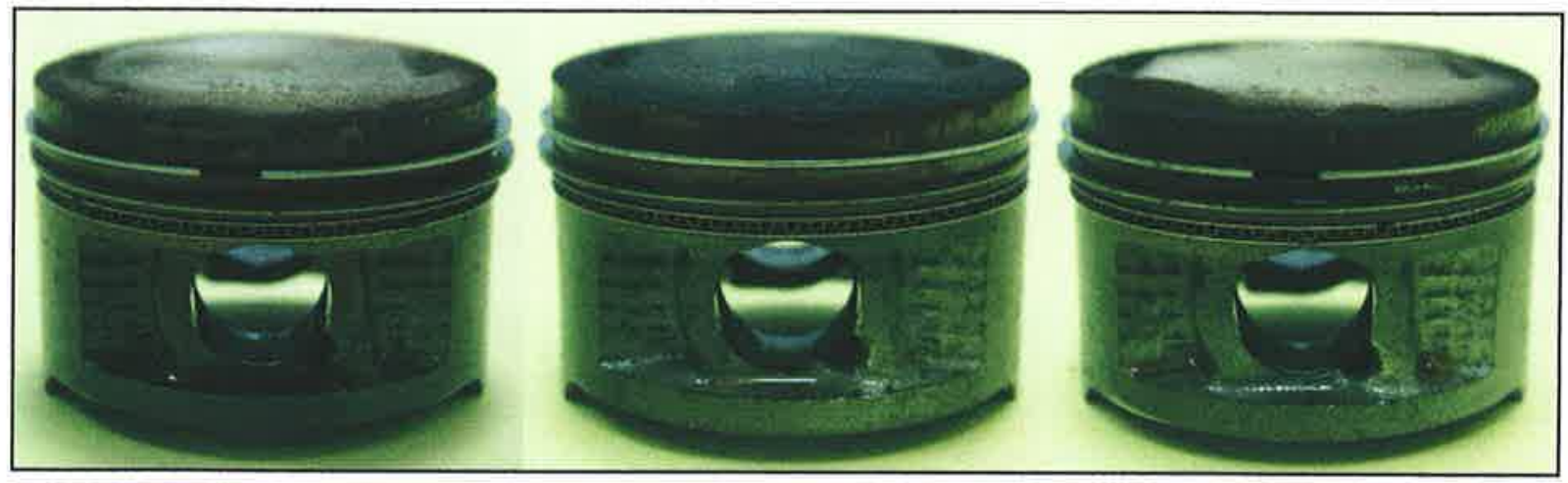

Figura 16: Vista lateral do pistão do motor E25 (esquerda), motor C-9 (centro) e motor E40 (direita).

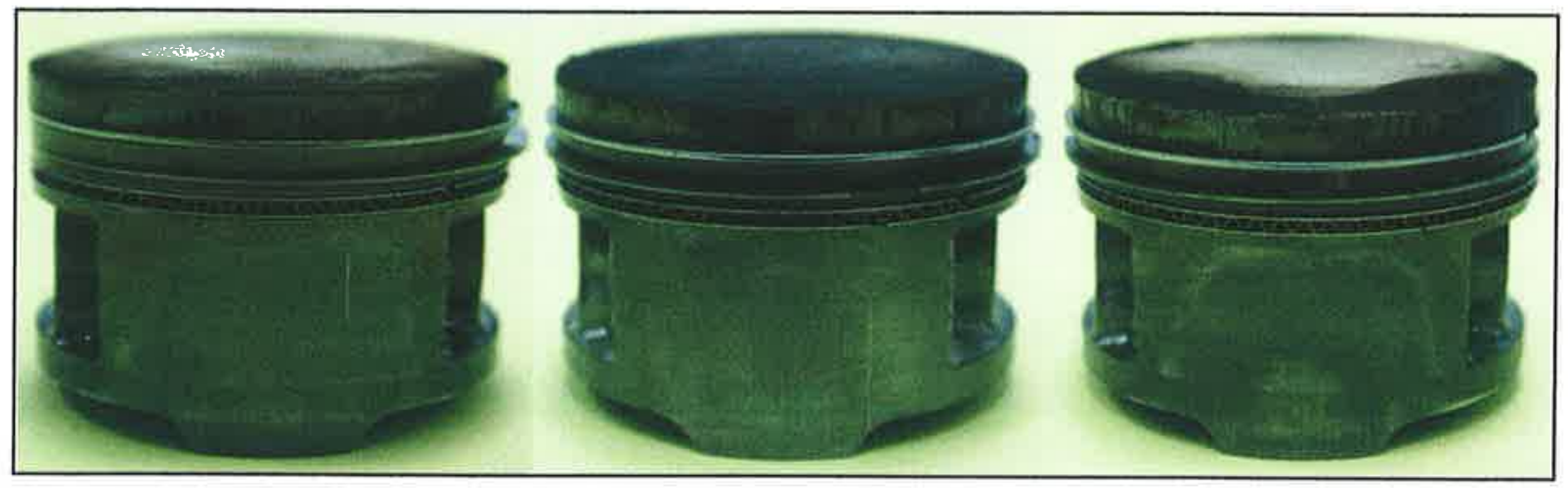

Figura 17: Outra vista lateral do pistão do motor E25 (esquerda), motor C-9 (centro) e motor E40 (direita).

Os cilindros em todos os testes de durabilidade não apresentaram diferenças visuais significativas entre eles. Os riscos nos cilindros são semelhantes entre os motores testados.

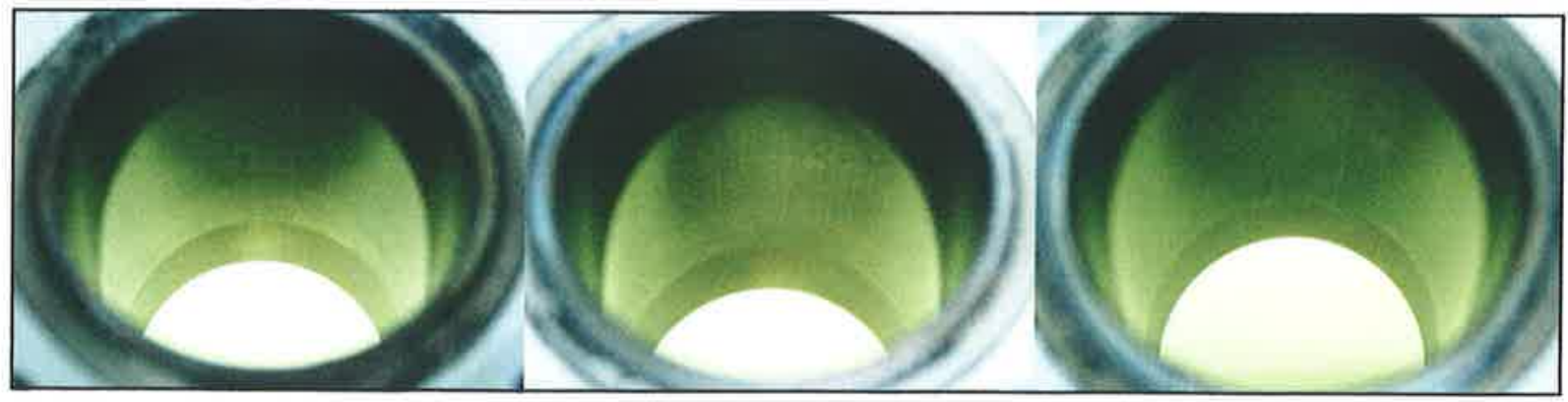

Figura 18: Cilindro do motor E25 (esquerda), motor C-9 (centro) e motor E40 (direita). 
A cuba do carburador do motor E40 apresentou resíduos no fundo do dreno decorrente do excesso do álcool combustivel utilizado na mistura. Estes resíduos podem causar entupimentos nos componentes do carburador.

A cuba do motor E25 e C-9 mantiveram sem resíduos em todo o experimento.

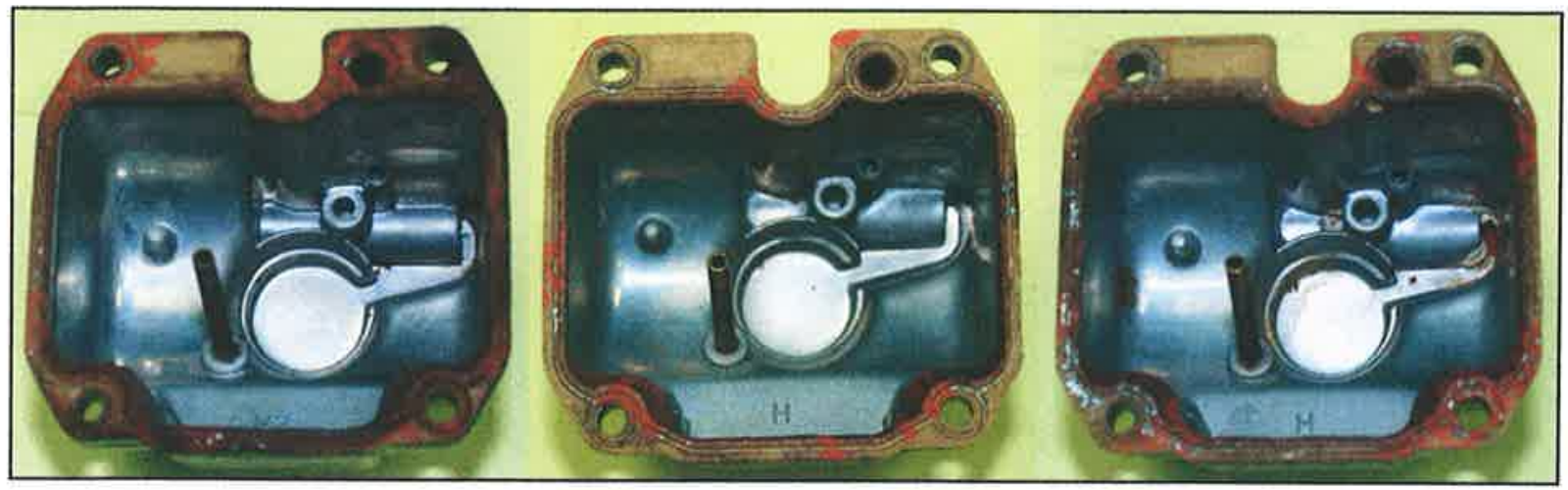

Figura 19: Cuba do carburador do motor E25 (esquerda), motor C-9 (centro) e motor E40 (direita).

Quanto às velas de ignição, coloração do eletrodo da vela de ignição mais clara está associada à do motor que utilizou E40, a mais escura está associada ao motor que utilizou C-9 e a tonalidade intermediária ao motor que utilizou E25.

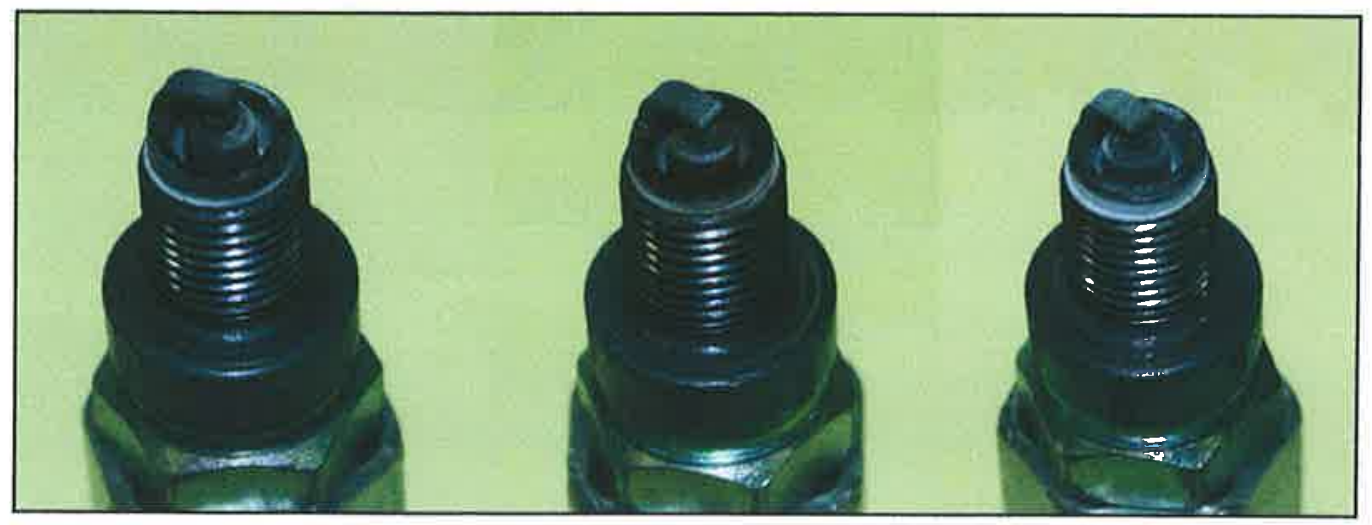

Figura 20: Vela de ignição do motor E25 (esquerda), motor C-9 (centro) e motor E40 (direita).

\subsection{Medições físicas dos motores}

De modo a simplificar a apresentação dos dados, as tabelas a seguir têm as medidas iniciais, obtidas antes do amaciamento, e as medidas finais, obtidas depois do teste de durabilidade. 
O período de tempo em que cada motor foi ensaiado, considerando amaciamento, levantamento das curvas de potência e ensaio de durabilidade totalizou mais de 125 horas.

$\mathrm{Na}$ Tabela 40 são mostrados os valores das massas das válvulas para cada motor, no início e no final do trabalho.

Tabela 40: Massa das válvulas em gramas.

\begin{tabular}{ccccccc}
\hline \multirow{2}{*}{ Motor } & \multicolumn{2}{c}{ Valor Inicial } & \multicolumn{2}{c}{ Valor Final } & \multicolumn{2}{c}{ Depósito na válvula } \\
\cline { 2 - 7 } & Admissão & Escape & Admissåo & Escape & Admissão & Escape \\
\hline E25 & 21,084 & 18,091 & 21,262 & 18,149 & 0,178 & 0,058 \\
\hline C9 & 21,498 & 18,171 & 21,659 & 18,230 & 0,161 & 0,059 \\
\hline E40 & 20,641 & 18,303 & 20,783 & 18,367 & 0,142 & 0,064 \\
\hline
\end{tabular}

A massa da bóia, conforme a Tabela 41, do carburador do motor que usou E40 foi a que apresentou maior variação, seguida por aquela do motor que usou C-9. Dessa forma, fica caracterizado que tanto o excesso de álcool no combustível como a presença de solvente alteram as composições do material da bóia de combustível ao longo do tempo de uso. É importante lembrar que o aumento de massa pode implicar em enriquecimento da mistura ao longo do tempo (o nível da cuba se eleva).

\begin{tabular}{cccc}
\multicolumn{4}{c}{ Tabela 41: Massa das bóias do carburador em gramas. } \\
\hline Motor & Valor inicial & Valor final & Acúmulo \\
\hline E25 & 5,818 & 5,825 & 0,007 \\
\hline C9 & 5,822 & 5,853 & 0,031 \\
\hline E40 & 5,832 & 5,900 & 0,068 \\
\hline
\end{tabular}

Conforme pode-se observar na Tabela 42 a seguir, os elastômeros do carburador não tiveram suas massas alteradas de formas diferentes.

Tabela 42: Massa dos elastômeros do carburador em gramas após os testes de durabilidade.

\begin{tabular}{lccc}
\hline Elastômeros (gramas) & E25 & C9 & E40 \\
\hline Vedação do afogador & 0,064 & 0,062 & 0,063 \\
\hline Vedação do pistonete & 0,222 & 0,231 & 0,201 \\
\hline Vedação do enriquecedor & 2,268 & 0,271 & 0,270 \\
\hline Vedação do difusor & 0,069 & 0,067 & 0,069 \\
\hline
\end{tabular}

As avaliações dos diâmetros dos cilindros mostram que não ocorreram danos significativos com o uso de qualquer dos três combustíveis, sendo que as tolerâncias 
mantiveram-se dentro dos valores especificados em projeto de acordo com os dados apresentados na Tabela 43 e 44.

Tabela 43: Valor inicial do diâmetro interno do cilindro (mm).

\begin{tabular}{ccccccc}
\hline Motor & D1 & D2 & D3 & D4 & D5 & D6 \\
\hline E25 & 54,011 & 54,009 & 54,010 & 54,011 & 54,010 & 54,014 \\
\hline C9 & 54,009 & 54,008 & 54,011 & 54,008 & 54,012 & 54,012 \\
\hline E40 & 54,011 & 54,011 & 54,012 & 54,013 & 54,013 & 54,015 \\
\hline
\end{tabular}

Tabela 44: Valor final do diâmetro interno do cilindro (mm).

\begin{tabular}{ccccccc}
\hline Motor & D1 & D2 & D3 & D4 & D5 & D6 \\
\hline E25 & 54,012 & 54,009 & 54,013 & 54,011 & 54,012 & 54,014 \\
\hline C9 & 54,011 & 54,008 & 54,011 & 54,008 & 54,013 & 54,012 \\
\hline E40 & 54,013 & 54,011 & 54,012 & 54,013 & 54,013 & 54,015 \\
\hline
\end{tabular}

Conseqüentemente, os valores de conicidade e ovalização não tiveram alteração no decorrer do experimento conforme as Tabelas 45 e 46.

\begin{tabular}{ccc} 
Tabela 45: Conicidade do cilindro $(\mathrm{mm})$ \\
\hline \multirow{2}{*}{ Motor } & \multicolumn{2}{c}{ Conicidade "T" } \\
& Valor inicial & Valor final \\
\hline E25 & 0,003 & 0,002 \\
\hline C9 & 0,003 & 0,002 \\
\hline E40 & 0,004 & 0,002 \\
\hline
\end{tabular}

Tabela 46: Ovalização do cilindro (mm).

\begin{tabular}{ccc}
\hline \multirow{2}{*}{ Motor } & \multicolumn{2}{c}{ Ovalização "R" } \\
& Valor inicial & Valor final \\
\hline E25 & 0,002 & 0,004 \\
\hline C9 & 0,004 & 0,005 \\
\hline E40 & 0,002 & 0,002 \\
\hline
\end{tabular}

Por análise visual, os depósitos formados sobre os pistões apresentaram diferentes nuances de coloração na cabeça do pistão com o uso dos diferentes combustíveis. O uso do E40 gerou o tom mais claro e o uso do C-9 gerou o tom mais escuro. Quanto ao desgaste, todos os pistões tiveram valores dentro das tolerâncias estabelecidas em projeto conforme a Tabela 47.

Tabela 47: Diâmetro do pistão (mm).

\begin{tabular}{cccc}
\hline Motor & Valor inicial & Valor final & Desgaste \\
\hline E25 & 53,981 & 53,922 & 0,059 \\
\hline C9 & 53,979 & 53,942 & 0,037 \\
\hline E40 & 53,980 & 53,938 & 0,042 \\
\hline
\end{tabular}


As folgas entre o cilindro e pistão apresentaram os valores na Tabela 48, mantendo-se dentro dos limites aceitáveis.

Tabela 48: Folga entre cilindro e pistão $(\mathrm{mm})$.

\begin{tabular}{ccc}
\hline Motor & Valor inicial & Valor final \\
\hline$E 25$ & 0,033 & 0,092 \\
\hline C9 & 0,033 & 0,070 \\
\hline$E 40$ & 0,035 & 0,077 \\
\hline
\end{tabular}

A análise visual nos anéis do pistão mostrou que somente o anel secundário de compressão do motor E40 apresentou maior desgaste. Na análise física todos os anéis estão dentro do limite especificado em projeto de acordo com a Tabela 49.

Tabela 49: Folga lateral dos anéis (mm).

\begin{tabular}{cccccccccccc}
\hline \multirow{2}{*}{ Motor } & Supe itor & Secundário & Raspador & Superior & Secundário & Raspador & Superior & Secundário & Raspador \\
\hline E25 & 0,05 & 0,03 & 0,12 & 0,06 & 0,04 & 0,13 & 0,06 & 0,04 & 0,13 \\
\hline C9 & 0,05 & 0,04 & 0,12 & 0,06 & 0,04 & 0,13 & 0,06 & 0,04 & 0,13 \\
\hline E40 & 0,04 & 0,03 & 0,12 & 0,06 & 0,04 & 0,14 & 0,06 & 0,04 & 0,14 \\
\hline
\end{tabular}

Sobre o cilindro de cada motor, foram medidas as folgas entre pontas conforme as Tabelas 50 e 51. Seguindo os resultados anteriores, os anéis, apesar de funcionar com diferentes misturas de combustíveis, tiveram desgastes dentro do especificado em projeto. O motor $\mathrm{C}-9$, entretanto, teve um desgaste um pouco superior aos demais conforme a Tabela 52 .

Tabela 50: Valor inicial da folga entre pontas dos anéis (mm).

\begin{tabular}{ccccc}
\hline \multirow{2}{*}{ Motor } & \multirow{2}{*}{ Superior } & \multirow{2}{*}{ Secundário } & \multicolumn{2}{c}{ Raspador/óleo } \\
\cline { 3 - 5 } & & & Superior & Inferior \\
\hline E25 & 0,29 & 0,29 & 0,45 & 0,49 \\
\hline C9 & 0,26 & 0,31 & 0,40 & 0,45 \\
\hline E40 & 0,30 & 0,32 & 0,50 & 0,46 \\
\hline
\end{tabular}

Tabela 51: Valor final da folga entre pontas dos anéis (mm).

\begin{tabular}{ccccc}
\hline \multirow{2}{*}{ Motor } & \multirow{2}{*}{ Superior } & \multirow{2}{*}{ Secundário } & \multicolumn{2}{c}{ Raspadorlóleo } \\
\cline { 3 - 5 } & & & Superior & Inferior \\
\hline E25 & 0,30 & 0,40 & 0,55 & 0,60 \\
\hline C9 & 0,26 & 0,40 & 0,60 & 0,64 \\
\hline E40 & 0,30 & 0,40 & 0,55 & 0,55 \\
\hline
\end{tabular}

Tabela 52: Desgaste entre pontas dos anéis ( $\mathrm{mm}$ ).

\begin{tabular}{ccccc}
\hline \multirow{2}{*}{ Motor } & \multirow{2}{*}{ Superior } & \multirow{2}{*}{ Secundário } & \multicolumn{2}{c}{ Raspador/óleo } \\
\cline { 3 - 5 } & & & Superior & Inferior \\
\hline E25 & 0,01 & 0,11 & 0,10 & 0,11 \\
\hline C9 & 0,00 & 0,09 & 0,20 & 0,19 \\
\hline E40 & 0,00 & 0,08 & 0,05 & 0,09 \\
\hline
\end{tabular}


Por último, verificou-se que praticamente não houve desgaste na bomba de óleo trocoidal, de acordo com a Tabela 53.

Tabela 53: Desgaste da bomba de óleo trocoidal $(\mathrm{mm})$.

\begin{tabular}{|c|c|c|c|c|c|c|c|c|c|}
\hline \multirow{2}{*}{ Motor } & \multicolumn{3}{|c|}{ Valor inicial } & \multicolumn{3}{|c|}{ Valor final } & \multicolumn{3}{|c|}{ Desgaste da bomba de bleo } \\
\hline & $A$ & $\mathrm{~B}$ & $\mathrm{C}$ & $\mathrm{A}$ & $\mathrm{B}$ & C & A & $\mathrm{B}$ & $\mathrm{C}$ \\
\hline E25 & 0,110 & 0,050 & 0,080 & 0,110 & 0,100 & 0,100 & 0,000 & 0,050 & 0,020 \\
\hline $\mathrm{Cg}$ & 0,100 & 0,070 & 0,120 & 0,100 & 0,070 & 0,120 & 0,000 & 0,000 & 0,000 \\
\hline $\mathrm{E} 40$ & 0,110 & 0,090 & 0,080 & 0,110 & 0,120 & 0,080 & 0,000 & 0,030 & 0,000 \\
\hline
\end{tabular}

No teste de vedação das válvulas, todos os motores apresentaram pequenos vazamentos após a desmontagem sem ficar identificada nenhuma anomalia associada ao uso de um combustível específico.

Em resumo, na análise física dos motores ensaiados, os desgastes, em geral, foram semelhantes, não havendo uma identificação clara do efeito da adulteração. 


\section{CONCLUSÕES}

O primeiro resultado importante a ser destacado é que o combustível adulterado com $20 \%$ de C- 9 , mantendo a porcentagem de $25 \%$ de AEAC, está de acordo com as especificações da ANP para gasolina comum tipo $\mathrm{C}$ conforme a Portaria ANP $n^{\circ} .309$ de 27/12/2001. Essa adulteração só seria identificada por análise de presença de marcador químico, introduzido antes do combustível deixar a petroquímica, enquanto o E40 é facilmente identificado com uma simples medição de teor alcoólico,

A principal diferenciação na análise dos combustíveis testados e preestabelecidos foi encontrada no desempenho do motor. Considerando que os motores não devem apresentar uma perda de desempenho superior a $7 \%$ ao longo do ensaio de durabilidade, tanto o motor C-9 como o motor E40 estariam reprovados. Porém, comparando o motor E25 com o C-9 no quesito desempenho, dificilmente o consumidor final notaria maiores prejuízos com o uso contínuo do combustivel C-9.

Em altas rotações, os consumos de combustivel de E25 e C-9 ficaram muito próximos de modo que torna-se quase impossível identificar o uso de combustível adulterado. Ao contrário, o E40 chega a ter um consumo aumentado em $10 \%$ nessa faixa de rotação quando comparado ao consumo de E25.

Nas emissões de poluentes, foram feitas medições parciais e finais ao longo do experimento. Os gases analisados foram os mesmos verificados na inspeção veicular do município de São Paulo que se inicia em 2009.

Novamente, os valores obtidos com o uso de E25 e de C-9 ficaram próximos. Isto é, mesmo com um combustível adulterado com a adição de $20 \%$ do solvente C-9, dependendo dos critérios de avaliação na inspeção veicular, a motocicleta poderia passar na inspeção de caráter ambiental.

Comparando as emissões do motor E25 com E40, os resultados mostraram que a adição de $15 \%$ de AEHC possibilita uma queda drástica nas emissões de CO e $\mathrm{HC}$, reduzindo-as em $60 \%$ e $30 \%$, respectivamente. Entretanto, as emissões de $\mathrm{CO}_{2}$ aumentaram $16 \%$ em relação ao motor E25, compatível com sua menor eficiência.

Entretanto, após a desmontagem dos motores, na análise visual, o motor que apresentou maior desgaste foi o que usou E40, especificamente nos anéis do pistão.

$\mathrm{Na}$ verificação dimensional das principais peças, todas estavam em conformidade com as especificações do projeto. Os motores que utilizaram C-9 e E40 
durante o ensaio de durabilidade, continuaram a apresentar desgastes dentro das tolerâncias permitidas pela fabricante.

Os elastômeros no carburador, medidas no final do experimento, não tiveram alteração significativa de massa nos três motores. Na massa da bóia de combustível, enquanto o motor E25 aumentou $0,12 \%$, no C-9 houve um acréscimo de $0,53 \%$ e no E40, 1,16\%. A utilização prolongada de combustível adulterado pode alterar a posição da bóia de combustivel e conseqüentemente, aumentar o consumo.

O motor E40 apresentou resíduos no fundo do dreno da cuba do carburador decorrente do excesso do álcool combustível utilizado na mistura. Estes resíduos podem causar entupimentos nos componentes do carburador, impedindo 0 funcionamento do motor.

As válvulas tiveram os acúmulos de goma semelhantes entre o motor E25 e motor C-9. Enquanto que o motor E40 teve menor acúmulo de goma principalmente pela adição de $\mathrm{AEHC}$. A haste da válvula do motor E40 teve o depósito de goma mais concentrado, enquanto que os motores E25 e C-9 tiveram depósitos mais porosos.

Caso o carburador esteja dentro das especificações do modelo em análise, uma das formas de verificar se o combustível está adulterado com a adição de C-9, sem a necessidade de desmontá-lo, seria por meio da coloração do eletrodo da vela de ignição. A tonalidade tenderia a ser mais escura que a observada quando se consome E25. No caso de motor que consome E40, o eletrodo teria uma coloração mais clara.

Nas análises do óleo lubrificante, a viscosidade e o indice de viscosidade ficaram com valores muito próximos para os três motores, não se tornando uma forma cabal para a verificação de adulteração no combustível utilizado. Da mesma forma, os desgastes avaliados pelos teores de ferro, alumínio e cobre, seguindo os mesmos princípios das medições físicas, também não identificam satisfatoriamente a adulteração.

O único resultado das análises de óleo lubrificante que evidenciou uma diferenciação entre os motores foi a oxidação. O motor que consumiu C-9 teve seu óleo oxidado mais intensamente que o que usou E25. Isso indica que uso contínuo do combustível adulterado com C-9 pode causar sérios danos ao motor se o período de troca de carga recomendado pelo fabricante não for reduzido. No caso da oxidação do óleo lubrificante do motor E40, ficou semelhante à oxidação do motor E25. 
A qualidade dos resultados apresentados é fortemente dependente da classe de potência dos motores utilizados nos ensaio. Ensaios com motores mais eficientes e de maiores potências máximas gerariam resultados mais diferenciados.

Notou-se que o número limitado de motores nesse estudo, um para cada mistura de combustível, não permite tirar resultados estatisticamente confiáveis. Recomenda-se para trabalhos futuros o uso de pelo menos três motores para cada mistura de combustível. 


\section{REFERÊNCIAS}

ALMEIDA, S. Q., TEIXEIRA L. S. G., GUIMARÃES P. R. B., et al, Estudo de uma Gasolina Formulada a partir de Mistura de Diferentes Solventes Comerciais, $3^{\circ}$ Congresso da Associação Brasileira das Agências de Regulação, ABAR, Vol. 2003.

ALVAREZ, J. Novas Rotas Tecnológicas para o Mercado Brasileiro, Seminário da Associação Brasileira de Engenharia Automotiva. São Paulo, julho de 2006.

ANP- Agência Nacional do Petróleo, Gás Natural e Biocombustíveis. Superintendência dos Estudos Estratégicos. Conjuntura e Informação. Solventes. Abril e Maio de 1999, n०4.

ANP - Agência Nacional do Petróleo, Gás Natural e Biocombusíveis. Especificação da Gasolina C. Resolução n³09 de 27/12/2001.

ANP - Agência Nacional do Petróleo, Gás Natural e Biocombusíveis. Especificações do Álcool Etílico Anidro Combustível (AEAC) e do Álcool Etílico Hidratado Combustível (AEHC). Resolução n³6 de 06/12/2005.

ANP - Agência Nacional do Petróleo, Gás Natural e Biocombusíveis. Superintendência de Qualidade de Produtos - SQP, Programa de Monitoramento da Qualidade dos Combustiveis - PMQC, Boletim Mensal da Qualidade dos Combustiveis Automotivos Brasileiros, de janeiro de 2006 a novembro de 2008.

AZEVEDO, D.A., WIEDMANN, L.S.M., d'ÁVILA, L.A.; Adulteration detection of Brazilian gasoline samples by statistical analysis; Fuel; v. 84; p. 467-473; 2005.

Benfaremo, N., LIU, S. C., Aditivos para Óleos de Cárter de Motores, Publicação Texaco Brasil S.A. Vol. 76, número 1, 1991.

BALL, D. J., BRIMBLECOMBE, P, NICHOLAS, F. M. Review of air quality criteria for the assessment of near-field impacts of road transport. TRRL Contractor Report 240. Transport and Road Research Laboratory, Crowthorne, 1991. 
BRASKEM, Benzeno - Ficha de Segurança de Informação de Produto Químico, Braskem S/A, pág. 1-23. Site: www.braskem.com.br, 07/2007.

DIAS, A. J., MACHADO, P. A. O., MACHADO E. H., DIANA R. A. D. Entendendo a Adulteração de Combustíveis. Grupo de Combate à Adulteração de Combustíveis do Ministério Público Federal no Estado de São Paulo. Endereço eletrônico: www.prsp.mpf.gov.br/marilia. Segunda edição, maio de 2007.

DUTRA, L. E. D. O Mercado e a Qualidade dos Combustíveis Automotivos. Agência Nacional de Petróleo, janeiro de 2004.

FLUMIGNAN, D. L., SILVA, C. E. F., FERREIRA, F. O. TANAKA, G. T. OLIVEIRA, J. E., et al., Seleção de amostras de gasolina para análise de marcadores através da análise explanatória quimiométrica dos parâmetros físico-químicos de monitoramento, $4^{0}$ PDPETRO, Campinas, SP 4.4.0487 - 1, 21 a 24 de Outubro de 2007.

GRAEDEL, T. E., HAWKINS, D. T., CLAXON, L. D. Atmospheric chemical compounds. Academic Press, Orlando, Florida, 1986.

HEYWOOD, J.B., Internal Combustion Engine Fundamentals, McGrawHill, 1988.

JUNG, C. F. Metodologia para pesquisa e desenvolvimento aplicado a novas tecnologias, produtos e processos. Rio de Janeiro: Axcel Editora, 2004.

MENDES, P. Desafios no combate à adulteração de gasolina por solventes: Programa de Marcação de Solventes. Informe Conjuntura e Informação, número 40, março de 2008.

OLIVEIRA, F. S. D., TEIXEIRA, L. S. G., ARAUJO, M. C. U., et al., "Screening Analysis to Detect Adulterations in Brazilian Gasoline Samples Using Distillation Curves" Fuel, Vol. 83, 7-8, 2004/5, pág. 917-923, 2004.

OWEN, K., COLEY, T., et al., Automotive Fuels Reference Book, segunda edição, Society of Automotive Engineers, Inc, 1990. 
PORTO, G. Estatal defende uso exclusivo de álcool anidro. Jornal O Estado de São Paulo, Ribeirão Preto, 24 de março de 2006.

POULTON, M.L., Alternative Fuels for Road Vehicles, Computational Mechanics Publications, 1994.

PUblicação fiat automóVeIS S.A., PALIO, SIENA, PALIO WEEKEND, STRADA, Manual de uso e manutenção, sem código, páginas A-129, A-130, A-131, F13 e F-14, setembro de 2006.

PUBLICAÇÃO FORD MOTOR COMPANY BRASIL LTDA., FORD KA, Manual do Proprietário, Garantia e Manutenção, código 97KX-19A321-CC, $4^{\mathrm{a}}$ edição, páginas 12 3 e 14-4, fevereiro de 2007.

PUBLICAÇÃO FORD MOTOR COMPANY BRASIL LTDA., FORD KA, Folha avulsa do Manual do Proprietário, Garantia e Manutenção, fevereiro de 2007.

PUBLICAÇÃo GENERAL MOTORS DO BRASIL LTDA., MONTANA, Manual do proprietário, código 93381351, páginas 13-5, 13-6 e 14-3, novembro de 2005.

PUBLICAÇÃo JORNAL DA TARDE, Seção Defenda-se, caderno semanal do Jornal do Carro no 1226, no 1228, no 1232 e no 1233, cidade de São Paulo, no período de 14 de fevereiro a 04 de abril de 2007.

PUBLICAÇÃO MOTO HONDA DA AMAZÔNIA LTDA., CG150 TITAN KS, ES, ESD, CG150 SPORT, CG150 JOB, Manual do proprietário, páginas 2-2 e 4-9, março de 2007.

PUBLICAÇÃO VOLKSWAGEN DO BRASIL LTDA., GOL, PARATI, Manual de Instruções, código 241.BR7.GLM.66, página 2-67, edição português de janeiro de 2004. 
PUBLICAÇÃO YAMAHA MOTOR DO BRASIL LTDA., YBR125K, YBR125E, YBR125ED, Manual do proprietário, código 5LX-F8199-P3, $5^{\text {a }}$ edição, página 4-9, março de 2003.

PUBLICAÇÃO YAMAHA MOTOR DO BRASIL LTDA., YBR125, Manual de Serviço, código 5HH-F8197-P0, 1a edição, fevereiro de 2000.

PUBLICAÇÃO YAMAHA MOTOR DO BRASIL LTDA., YBR125K, YBR125E, YBR125ED, Catálogo de Peças, código 1D5HH-280P1, $1^{\text {a }}$ edição, agosto de 2004.

PUBLICAÇÃO YAMAHA MOTOR CO., LTD., Yamaha Technical Academy - Bronze, Motorcycle Service Engineering General, código 90894-00105, $1^{\text {a }}$ edição, junho de 2000.

PUBLICAÇÃO YAMAHA MOTOR DO BRASIL LTDA., YZF-R1, Manual de Serviço, código 4C8-F8197-WO, 1ª edição, outubro de 2007.

ROLLI, C. Cresce fraude de solvente como combustível. Jornal Folha de São Paulo. São Paulo, agosto de 2005.

SA, W. Aditivação Total da Gasolina no Brasil, Seminário da Associação Brasileira de Engenharia Automotiva. ABRAFA (Associação Brasileira dos Fabricantes de Aditivos). São Paulo, 15 de maio de 2008.

SIMIONATTO, E. L. Entrevista concedida a revista eletrônica do departamento de Química da Universidade Federal de Santa Catarina. Endereço eletrônico: http://www.qmc.ufsc.br/gmcweb/artigos/gasolina/html, novembro de 2006.

SOUZA NETO, G. J., MARINHO K. L. C., SILVEIRA NETO O. S. Responsabilidade Civil dos Distribuidores e Revendedores por Adulteração de Combustíveis à Luz do Direito do Consumidor. Trabalho Técnico Científico foi preparado para apresentação no $3^{\circ}$ Congresso Brasileiro de P\&D em Petróleo e Gás. Salvador-BA, outubro de 2005. 
STEINBAUM, V. Programa de Inspeção e Manutenção de Veículos em Uso Programa I/M-SP. Seminário da Associação Brasileira de Engenharia Automotiva. Prefeitura do Município de São Paulo. São Paulo, 15 de maio de 2008.

TAKESHITA, E. V. Adulteração de Gasolina por Adição de Solventes: Análise dos Parâmetros Físico-químicos. Dissertação submetida ao programa de Pós-graduação em Engenharia Química do Centro Tecnológico da Universidade Federal de Santa Catarina para orientação do título de mestre em Engenharia Química. Florianópolis-SC, março de 2006. 


\subsection{APÊNDICE A - Procedimento para a medição das principais peças}

Antes de iniciar os testes de durabilidade foram desmontados os três motores para certificação das folgas e dimensões das peças (protocolamento). As medições realizadas nas válvulas de admissão e escape são: o comprimento livre das molas com a utilização de um paquímetro centesimal como mostra a Figura A1, o diâmetro interno dos guias de válvulas com um emicro milesimal como mostra a Figura A2, o diâmetro das hastes das válvulas com um micrômetro milesimal, a folga entre as hastes e os guias de válvulas com uma simples subtração dos valores encontrados e as massas das válvulas e bóia de combustível para uma futura comparação.

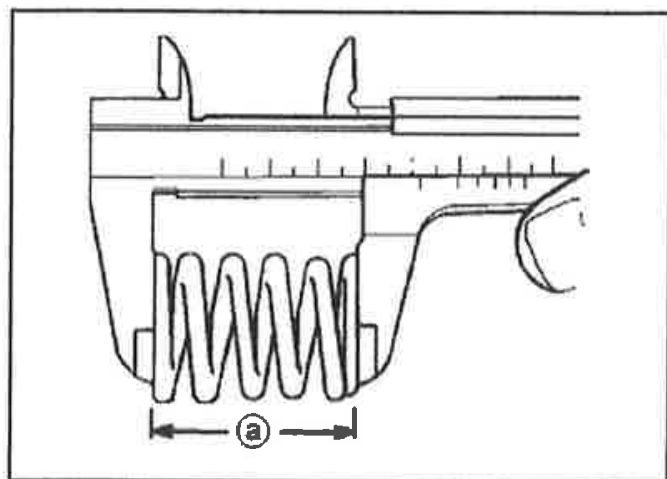

Figura A1: Comprimento da mola da válvula (PUBLICAÇÃO YAMAHA, 2000).

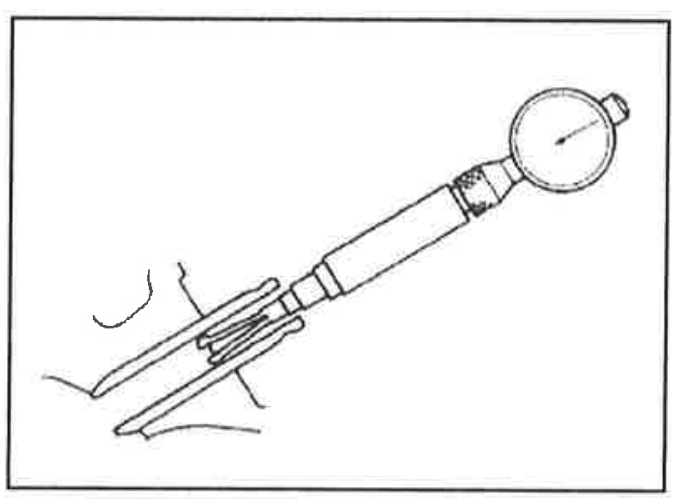

Figura A2: Diâmetro interno do guia da válvula (PUBLICAÇÃO YAMAHA, 2000).

No eixo comando foram medidos os cames no círculo de base e no ressalto com o micrômetro milesimal como mostra a Figura A3. Os diâmetros internos dos balancins foram medidos com o uso de um emicro milesimal; os diâmetros externos dos pinos dos balancins com um micrômetro milesimal como mostra a Figura A4 e as folgas entre os balancins e os pinos com uma simples subtração dos valores encontrados. Além disso, mediu-se a folga entre os eletrodos da vela de ignição (gap) utilizada.

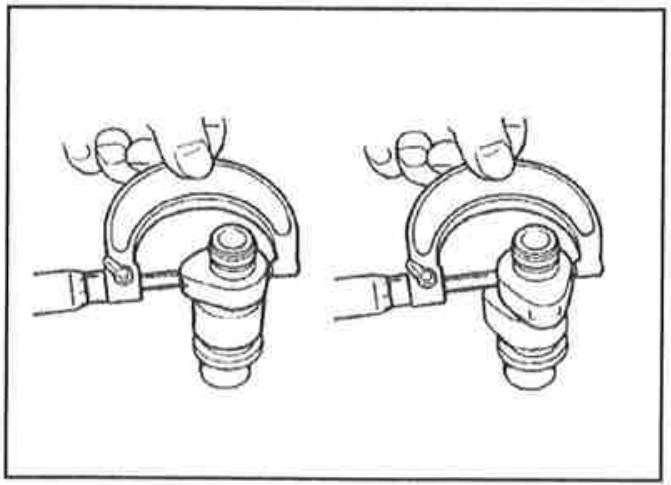

Figura A3: Dimensões do came do comando de válvulas (PUBLICAÇÃO YAMAHA, 2000).

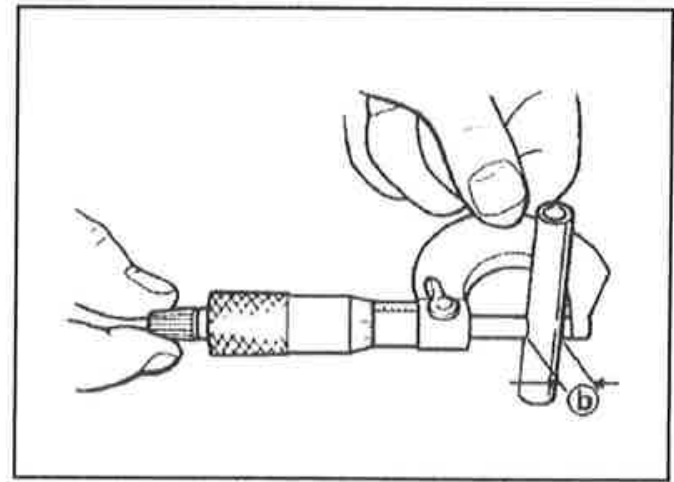

Figura A4: Diâmetro externo do pino do balancim (PUBLICAÇÃO YAMAHA, 2000). 
No motor, foi medido o diâmetro interno do cilindro com um micrômetro e um relógio comparador milesimal como mostra a Figura A5. As seis medidas realizadas foram distribuídas em dois pontos cruzados no PMS, próximos ao cabeçote, dois em seção intermediária e dois no PMI localizados na região das aletas do cilindro. Das três medições, o diâmetro do cilindro é o maior valor encontrado conforme o manual de serviço do modelo. Além do diâmetro, são medidas a conicidade e a ovalização. $A$ conicidade é a subtração dos valores encontrados, conforme a figura abaixo, no mesmo eixo vertical entre D1, D3 e D5 ou entre D2, D4 e D6. A ovalização é o maior número encontrado na subtração entre D1 e D2 ou D3 e D4 ou D5 e D6.

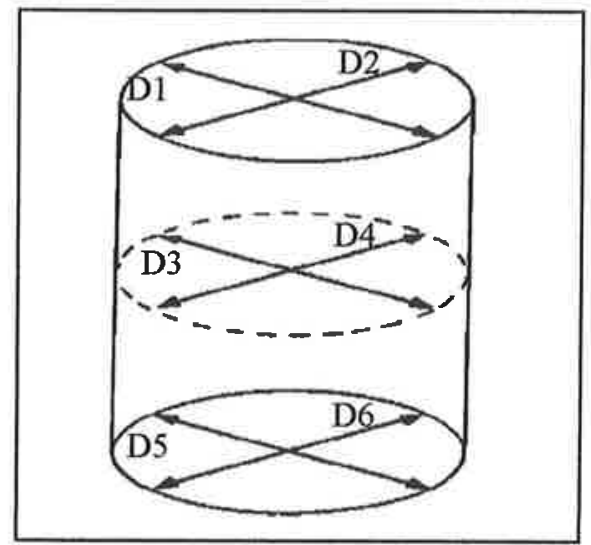

Figura A5: Diâmetro interno do cilindro (PUBLICAÇÃO YAMAHA, 2000).

O pistão é medido com um micrômetro milesimal na parte inferior. O micrômetro é posicionado a uma distância (a) de 4,5 milímetros, conforme a Figura A6. A subtração do maior diâmetro interno encontrado no cilindro com o diâmetro externo do pistão é a folga entre o cilindro e pistão. Além disso, foram medidos o diâmetro interno do furo passante do pino do pistão como mostra a Figura $A 7$, o diâmetro externo do pino do pistão e a folga.

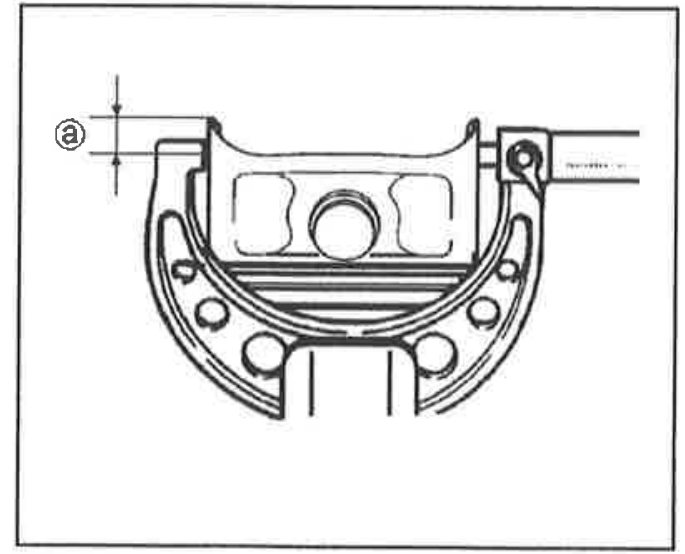

Figura A6: Diâmetro do pistăo (PUBLICAÇÃO YAMAHA, 2000).

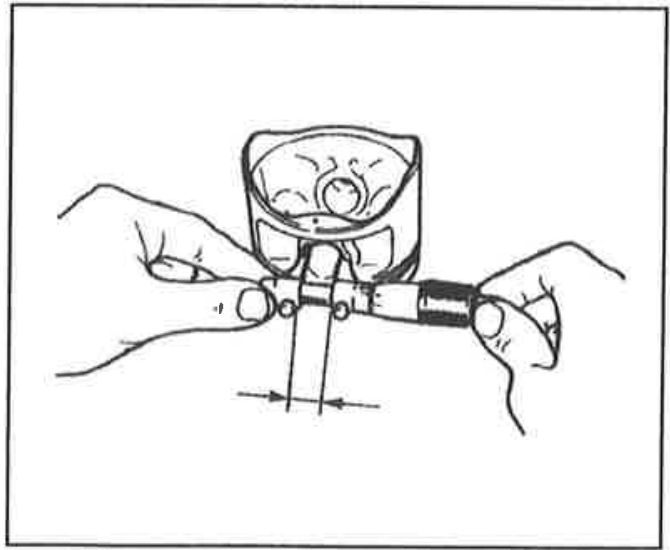

Figura A7: Diâmetro interno do pino do pistão (PUBLICAÇÃO YAMAHA, 2000). 
Os anéis de vedação, raspador e de óleo são medidos com o calibrador de lâminas a folga lateral e a folga entre pontas no cilindro. A primeira medição é feita com os anéis instalados no pistão como mostra a Figura A8 e a segunda com cada anel no cilindro como mostra a Figura A9. Para medir no cilindro, é necessário que o pistão seja empurrado de cima para baixo de forma que o anel fique paralelo com a base do cilindro. Não se mede a folga entre $o$ anel de óleo e o cilindro.

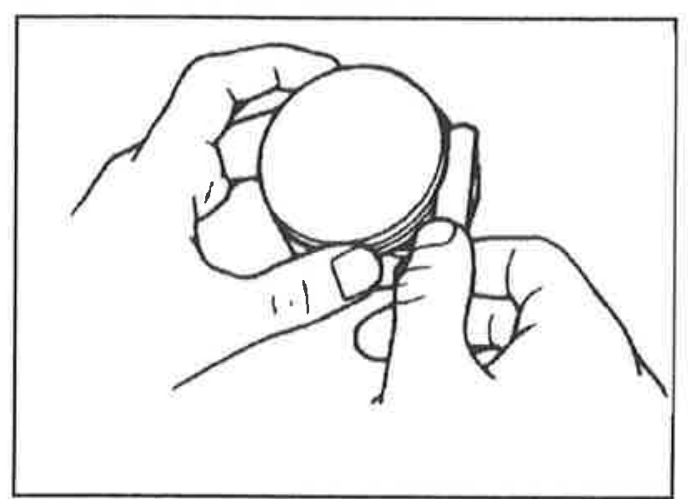

Figura A8: Folga dos anéis no pistão (PUBLICAÇÃO YAMAHA, 2000).

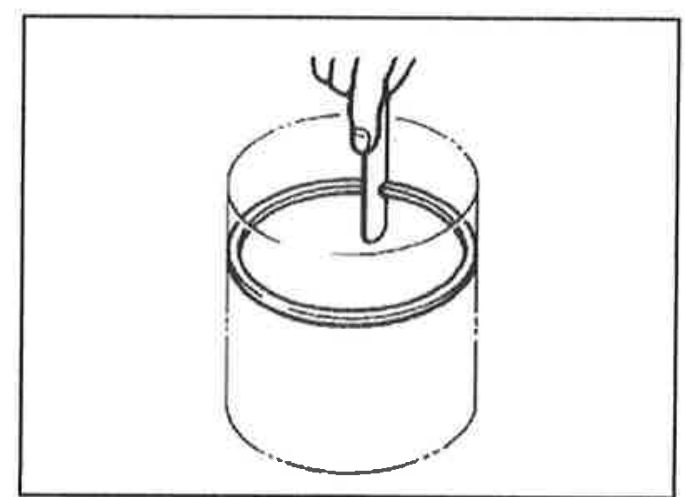

Figura A9: Folga dos anéis no cilindro (PUBLICAÇÃO YAMAHA, 2000).

Na parte inferior do motor são medidos: o alinhamento do virabrequim com o auxílio de um entre-pontas e relógio comparador milesimal, a folga entre a biela e o virabrequim com o calibrador de lâminas como mostra a Figura $A 10$, e a largura entre os dois contrapesos do virabrequim com o paquímetro como mostra a Figura 11. Caso alguma medida esteja fora de especificação, é necessário ajustá-las conforme o manual de serviço do modelo.

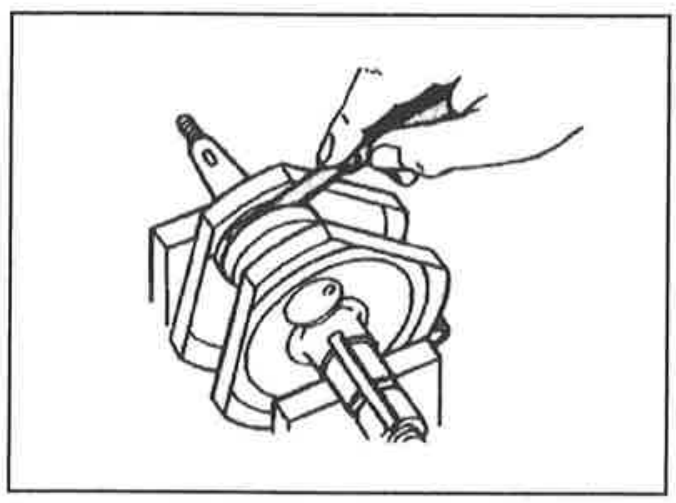

Figura A10: Folga entre a biela e o virabrequim (PUBLICAÇÃO YAMAHA, 2000).

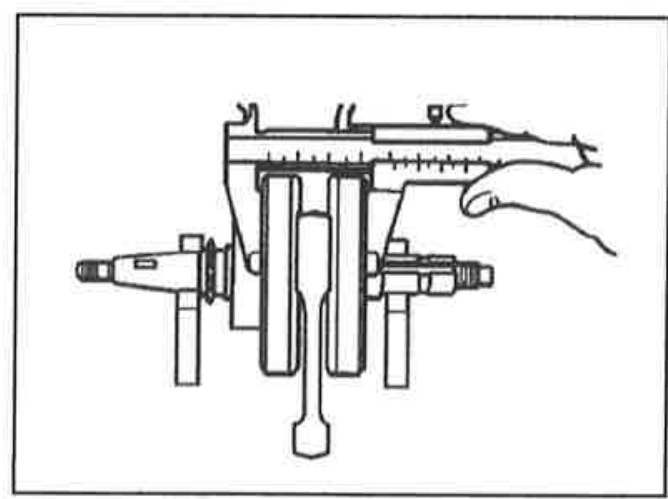

Figura A11: Distância entre os contrapesos (PUBLICAÇÃO YAMAHA, 2000).

A folga da bomba de óleo trocoidal é medida com o calibrador de lâminas em três pontos como mostra a Figura $A 12$ : folga $(A)$ entre o rotor interno (1) com o externo 
(2), folga (B) do rotor externo (2) com a sede da bomba (3) e folga (C) dos rotores (1) e (2) com a sede da bomba de óleo (3).

A bóia de combustivel da Figura A13 é pesada para que, no final do ensaio de durabilidade, seja verificado o efeito do combustível utilizado na sua massa final.
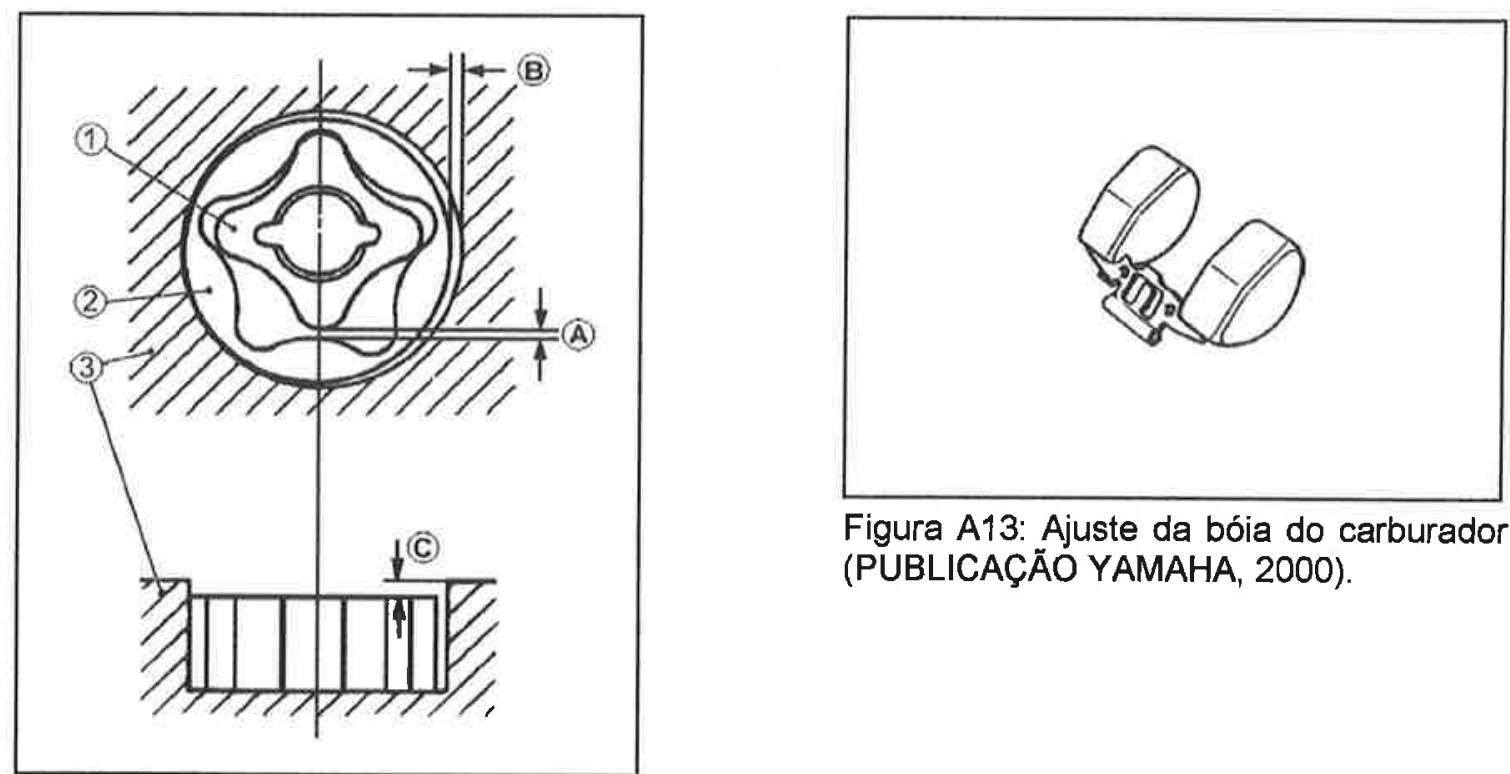

Figura A13: Ajuste da bóia do carburador (PUBLICAÇÃO YAMAHA, 2000).

Figura A12: Folga da bomba trocoidal (PUBLICAÇÃO YAMAHA, 2000). 


\subsection{APÊNDICE B - Medições físicas dos motores}

Tabela B1: Comprimento livre da mola $(\mathrm{mm})$.

\begin{tabular}{ccccccc}
\hline \multirow{2}{*}{ Motor } & \multicolumn{2}{c}{ Valor Inicial } & \multicolumn{2}{c}{ Valor Final } & \multicolumn{2}{c}{ Desgaste } \\
\cline { 2 - 7 } & Admissão & Escape & Admissåo & Escape & Admissão & Escape \\
\hline E25 & 38,231 & 38,278 & 37,235 & 37,137 & 0,996 & 1,141 \\
\hline C9 & 38,156 & 38,232 & 37,436 & 37,421 & 0,720 & 0,811 \\
\hline E40 & 38,298 & 38,207 & 37,541 & 37,405 & 0,757 & 0,802 \\
\hline
\end{tabular}

Tabela B2: Diâmetro interno do guia da válvula $(\mathrm{mm})$.

\begin{tabular}{ccccccc}
\hline \multirow{2}{*}{ Motor } & \multicolumn{2}{c}{ Valor Inicial } & \multicolumn{2}{c}{ Valor Final } & \multicolumn{2}{c}{ Desgaste } \\
\cline { 2 - 7 } & Admisså̃o & Escape & Admissăo & Escape & Admissåo & Escape \\
\hline E25 & 5,003 & 5,003 & 5,003 & 5,004 & 0,000 & 0,001 \\
\hline C9 & 5,004 & 5,003 & 5,006 & 5,007 & 0,002 & 0,004 \\
\hline E40 & 5,004 & 5,003 & 5,004 & 5,006 & 0,000 & 0,003 \\
\hline
\end{tabular}

Tabela B3: Diâmetro da haste das válvulas (mm).

\begin{tabular}{ccccccc}
\hline \multirow{2}{*}{ Motor } & \multicolumn{2}{c}{ Valor Inicial } & \multicolumn{2}{c}{ Valor Final } & \multicolumn{2}{c}{ Desgaste } \\
\cline { 2 - 7 } & Admisså̊o & Escape & Admissão & Escape & Admisså̃o & Escape \\
\hline E25 & 4,984 & 4,972 & 4,976 & 4,962 & 0,008 & 0,010 \\
\hline C9 & 4,983 & 4,968 & 4,979 & 4,963 & 0,004 & 0,005 \\
\hline E40 & 4,982 & 4,970 & 4,977 & 4,964 & 0,005 & 0,006 \\
\hline
\end{tabular}

Tabela B4: Folga entre a haste da válvula com o diâmetro interno do guia da válvula $(\mathrm{mm})$.

\begin{tabular}{ccccccc}
\hline \multirow{2}{*}{ Motor } & \multicolumn{2}{c}{ Valor Inicial } & \multicolumn{2}{c}{ Valor Final } & \multicolumn{2}{c}{ Desgaste } \\
\cline { 2 - 7 } & Admissåo & Escape & Admissäo & Escape & Admissåo & Escape \\
\hline E25 & 0,019 & 0,031 & 0,027 & 0,042 & 0,008 & 0,011 \\
\hline C9 & 0,021 & 0,035 & 0,027 & 0,044 & 0,006 & 0,009 \\
\hline E40 & 0,022 & 0,033 & 0,027 & 0,042 & 0,005 & 0,009 \\
\hline
\end{tabular}

Tabela B5: Came do eixo comando - parte com o ressalto (mm).

\begin{tabular}{ccccccc}
\hline \multirow{2}{*}{ Motor } & \multicolumn{2}{c}{ Valor Inicial } & \multicolumn{2}{c}{ Valor Final } & \multicolumn{2}{c}{ Desgaste } \\
\cline { 2 - 7 } & Admissăo & Escape & Admissåo & Escape & Admissåo & Escape \\
\hline E25 & 25,894 & 25,897 & 25,881 & 25,874 & 0,013 & 0,023 \\
\hline C9 & 25,886 & 25,869 & 25,854 & 25,862 & 0,032 & 0,007 \\
\hline E40 & 25,902 & 25,876 & 25,893 & 25,769 & 0,009 & 0,107 \\
\hline
\end{tabular}


Tabela B6: Came do eixo comando - parte sem o ressalto ( $\mathrm{mm}$ ).

\begin{tabular}{ccccccc}
\hline \multirow{2}{*}{ Motor } & \multicolumn{2}{c}{ Valor Inicial } & \multicolumn{2}{c}{ Valor Final } & \multicolumn{2}{c}{ Desgaste } \\
\cline { 2 - 7 } & Admissåo & Escape & Admissão & Escape & Admissåo & Escape \\
\hline E25 & 21,259 & 21,076 & 21,252 & 21,067 & 0,007 & 0,009 \\
\hline C9 & 21,246 & 21,088 & 21,242 & 21,056 & 0,004 & 0,032 \\
\hline E40 & 21,250 & 21,090 & 21,241 & 21,058 & 0,009 & 0,032 \\
\hline
\end{tabular}

Tabela B7: Diâmetro interno do balancim (mm).

\begin{tabular}{ccccccc}
\hline \multirow{2}{*}{ Motor } & \multicolumn{2}{c}{ Valor Inicial } & \multicolumn{2}{c}{ Valor Final } & \multicolumn{2}{c}{ Desgaste } \\
\cline { 2 - 7 } & Admissåo & Escape & Admissão & Escape & Admissão & Escape \\
\hline E25 & 10,011 & 10,015 & 10,012 & 10,018 & 0,001 & 0,003 \\
\hline C9 & 10,013 & 10,010 & 10,014 & 10,013 & 0,001 & 0,003 \\
\hline E40 & 10,010 & 10,015 & 10,011 & 10,017 & 0,001 & 0,002 \\
\hline
\end{tabular}

Tabela B8: Diâmetro externo do pino do balancim ( $\mathrm{mm}$ ).

\begin{tabular}{ccccccc}
\hline \multirow{2}{*}{ Motor } & \multicolumn{2}{c}{ Valor Inicial } & \multicolumn{2}{c}{ Valor Final } & \multicolumn{2}{c}{ Desgaste } \\
\cline { 2 - 7 } & Admissăo & Escape & Admissão & Escape & Admissåo & Escape \\
\hline E25 & 9,988 & 9,984 & 9,983 & 9,978 & 0,005 & 0,006 \\
\hline C9 & 9,989 & 9,988 & 9,985 & 9,983 & 0,004 & 0,005 \\
\hline E40 & 9,988 & 9,988 & 9,983 & 9,981 & 0,005 & 0,007 \\
\hline
\end{tabular}

Tabela B9: Folga entre o pino e o balancim ( $\mathrm{mm}$ ).

\begin{tabular}{ccccccc}
\hline \multirow{2}{*}{ Motor } & \multicolumn{2}{c}{ Valor Inicial } & \multicolumn{2}{c}{ Valor Final } & \multicolumn{2}{c}{ Desgaste } \\
\cline { 2 - 7 } & Admissão & Escape & Admissão & Escape & Admissão & Escape \\
\hline E25 & 0,023 & 0,031 & 0,029 & 0,040 & 0,006 & 0,009 \\
\hline C9 & 0,024 & 0,022 & 0,029 & 0,030 & 0,005 & 0,008 \\
\hline E40 & 0,022 & 0,027 & 0,028 & 0,036 & 0,006 & 0,009 \\
\hline
\end{tabular}

Tabela B10: Diâmetro do pino do pistão (mm).

\begin{tabular}{cccc}
\hline Motor & Valor inicial & Valor final & Desgaste \\
\hline E25 & 14,995 & 14,995 & 0,000 \\
\hline C9 & 14,993 & 14,991 & 0,002 \\
\hline E40 & 14,994 & 14,992 & 0,002 \\
\hline
\end{tabular}

Tabela B11: Diâmetro interno do alojamento do pino do pistão (mm).

\begin{tabular}{cccc}
\hline Motor & Valor inicial & Valor final & Desgaste \\
\hline E25 & 15,005 & 15,010 & 0,005 \\
\hline C9 & 15,005 & 15,009 & 0,004 \\
\hline E40 & 15,005 & 15,007 & 0,002 \\
\hline
\end{tabular}


Tabela B12: Folga entre o pistão e o pino do pistão (mm).

\begin{tabular}{cccc}
\hline Motor & Valor inicial & Valor final & Desgaste \\
\hline E25 & 0,010 & 0,015 & 0,005 \\
\hline C9 & 0,012 & 0,018 & 0,006 \\
\hline E40 & 0,011 & 0,015 & 0,004 \\
\hline
\end{tabular}

Tabela B13: Alinhamento do virabrequim (mm).

\begin{tabular}{ccccc}
\hline \multirow{2}{*}{ Motor } & \multicolumn{2}{c}{ Valor inicial } & \multicolumn{2}{c}{ Valor final } \\
\cline { 2 - 5 } & $\begin{array}{c}\text { Lado } \\
\text { balanceador }\end{array}$ & $\begin{array}{c}\text { Lado } \\
\text { comando }\end{array}$ & $\begin{array}{c}\text { Lado } \\
\text { balanceador }\end{array}$ & $\begin{array}{c}\text { Lado } \\
\text { omando }\end{array}$ \\
\hline E25 & 0,020 & 0,030 & 0,068 & 0,005 \\
\hline C9 & 0,029 & 0,027 & 0,059 & 0,002 \\
\hline E40 & 0,016 & 0,018 & 0,009 & 0,039 \\
\hline
\end{tabular}

Tabela B14: Folga lateral da biela com o virabrequim (mm).

\begin{tabular}{ccc}
\hline Motor & Valor inicial & Valor final \\
\hline E25 & 0,150 & 0,200 \\
\hline$C 9$ & 0,350 & 0,400 \\
\hline$E 40$ & 0,300 & 0,250 \\
\hline
\end{tabular}

Tabela B15: Largura do virabrequim (mm).

\begin{tabular}{ccc}
\hline Motor & Valor inicial & Valor final \\
\hline E25 & 46,960 & 46,990 \\
\hline C9 & 46,990 & 47,150 \\
\hline$E 40$ & 46,970 & 47,020 \\
\hline
\end{tabular}


罗

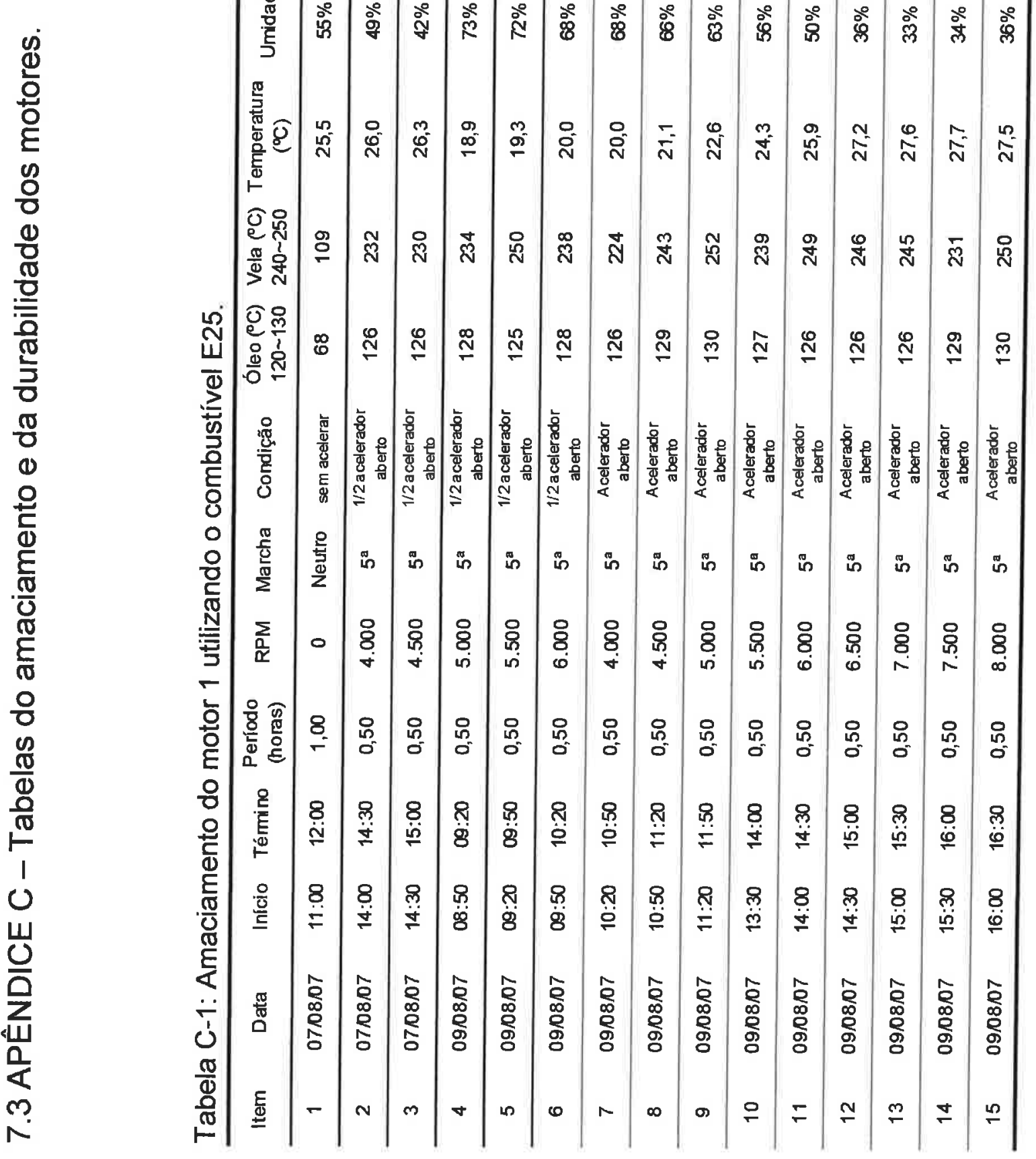




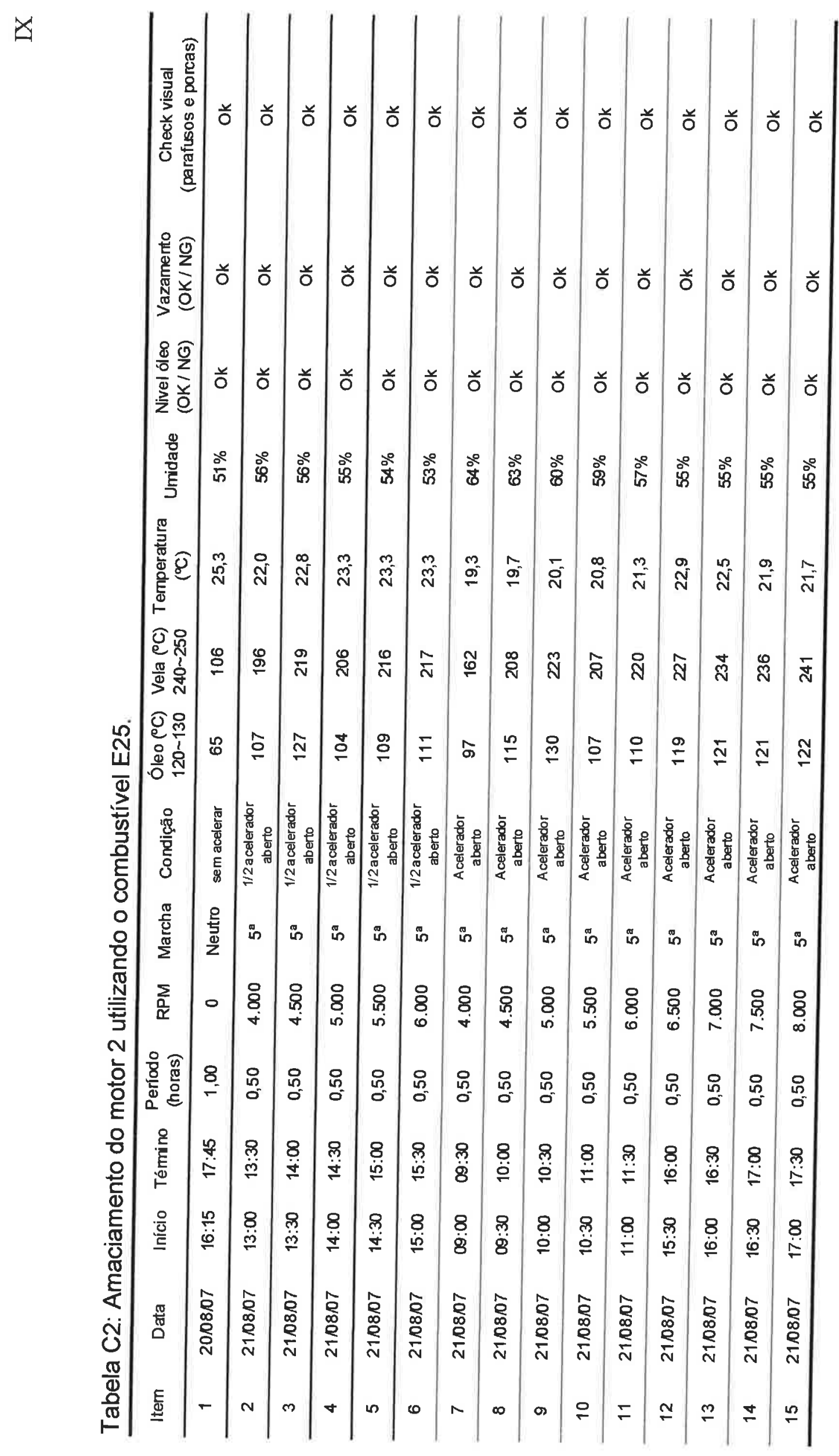




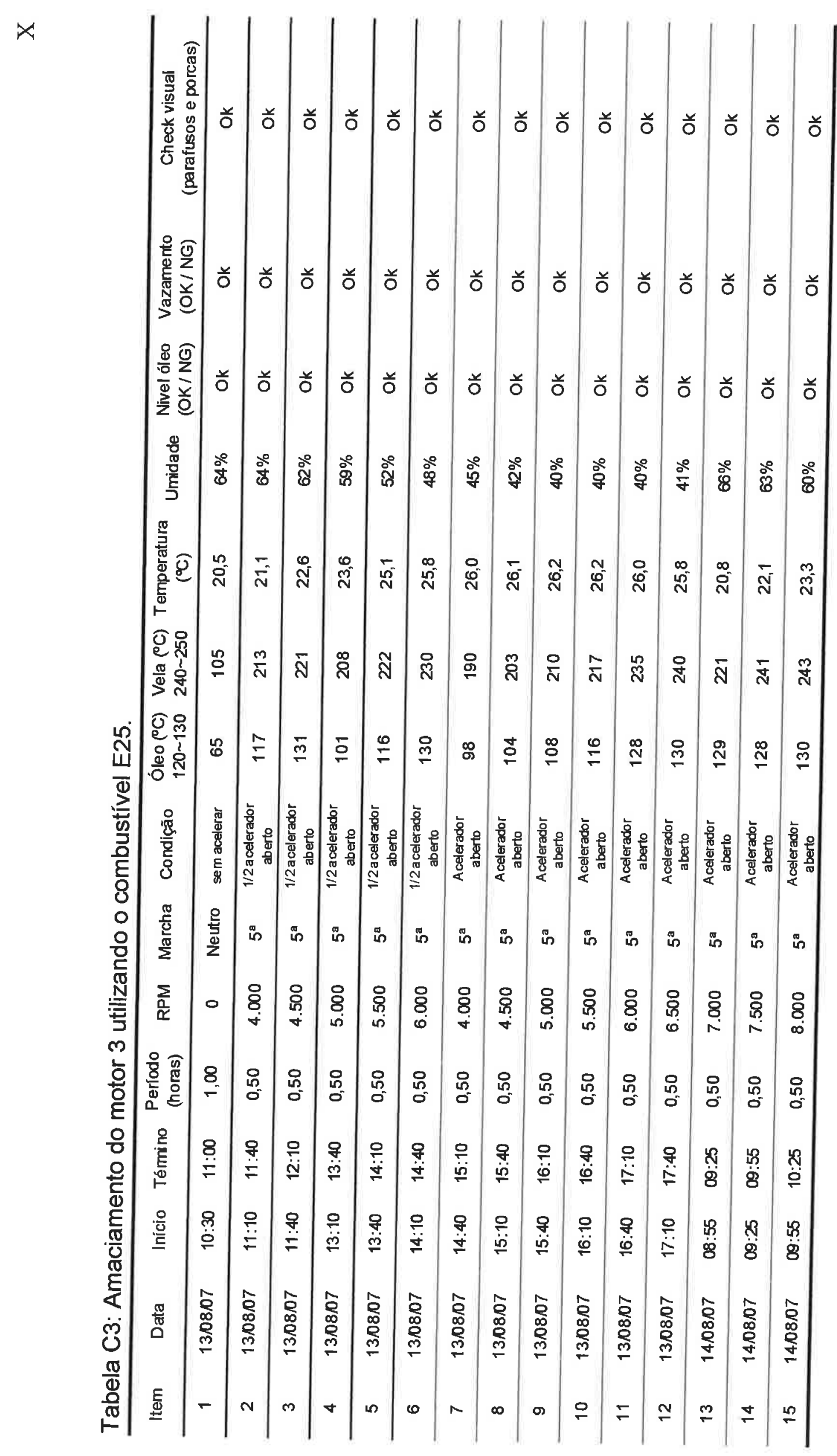




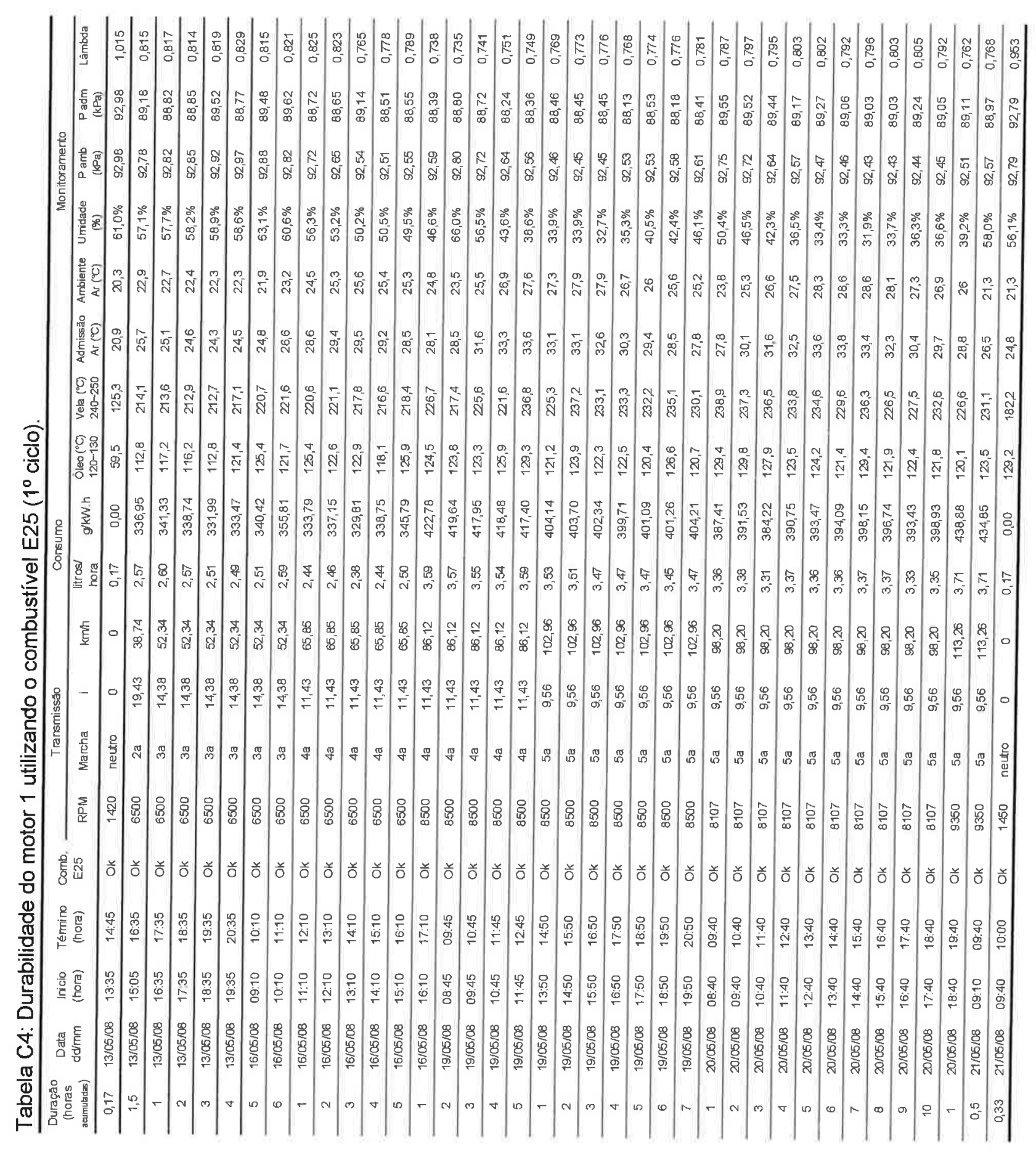




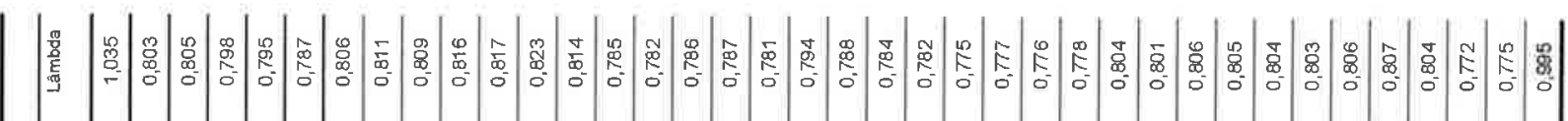

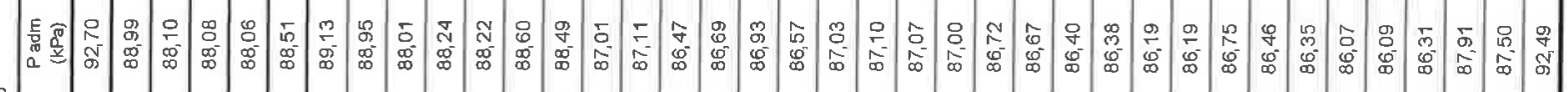

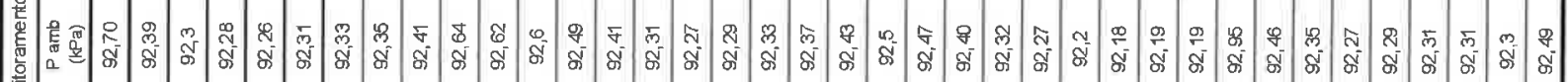

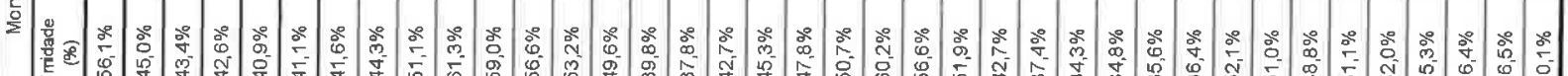

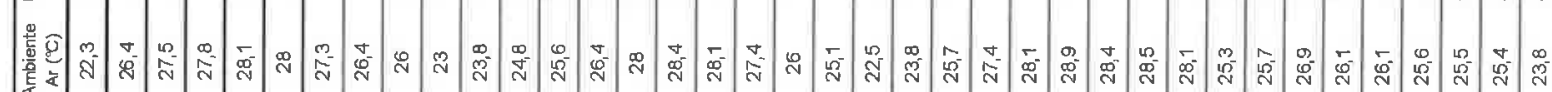

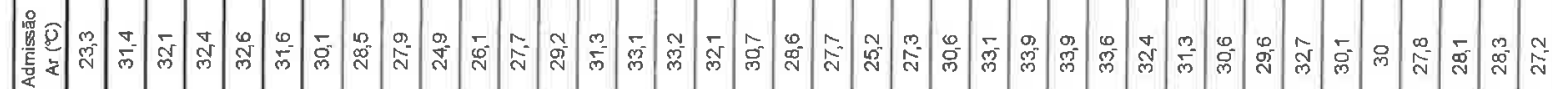

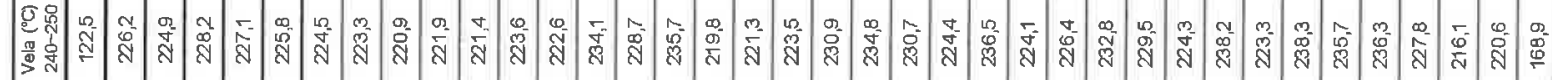

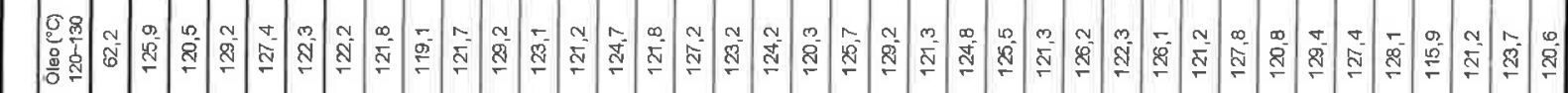

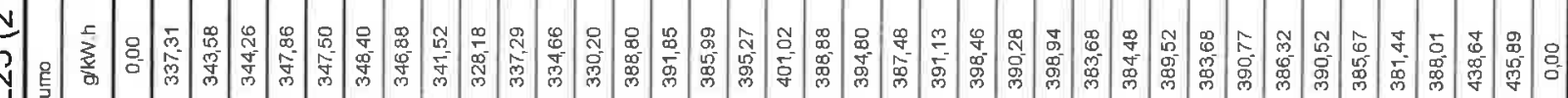
产

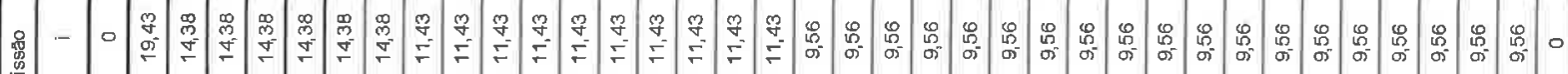

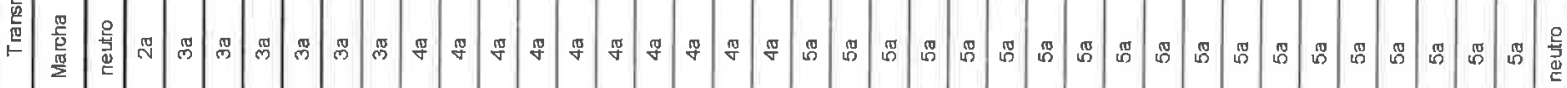

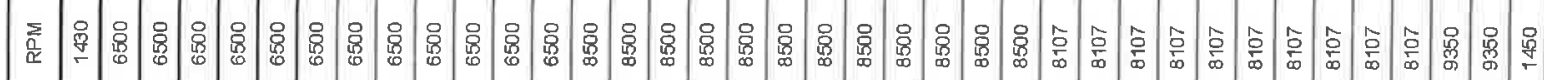

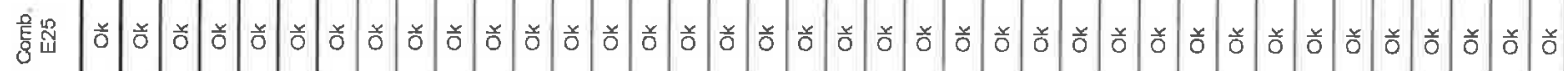

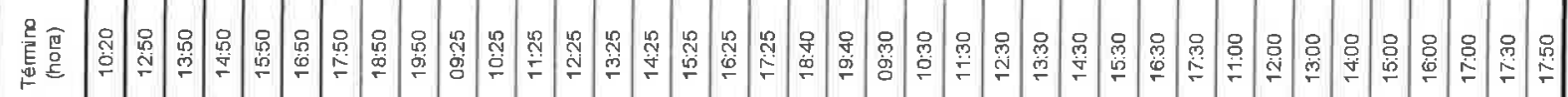

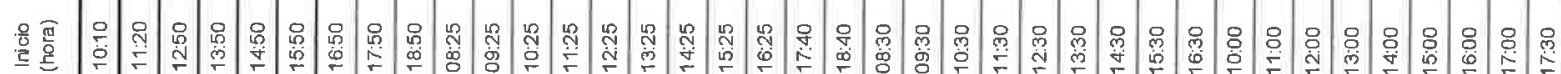

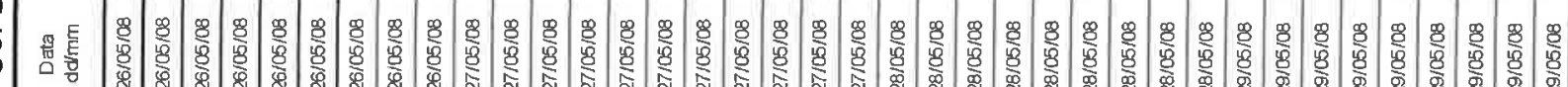

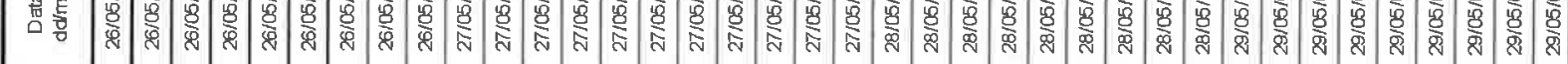
寜

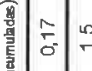




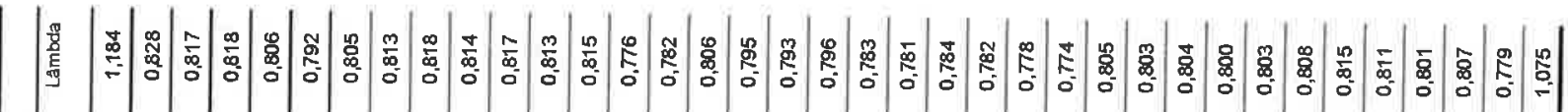

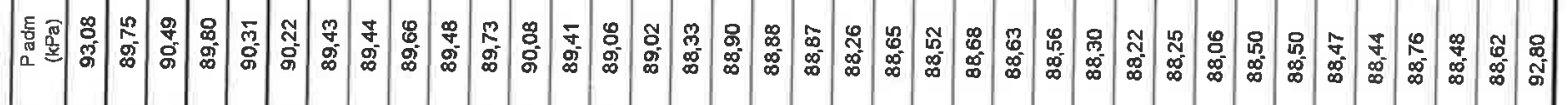

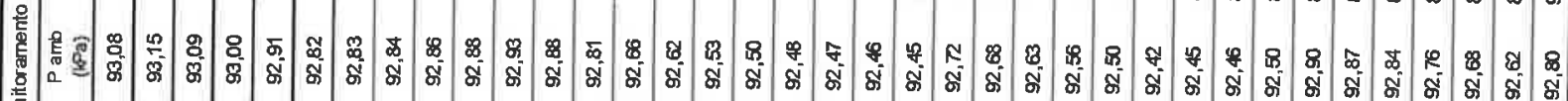

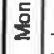

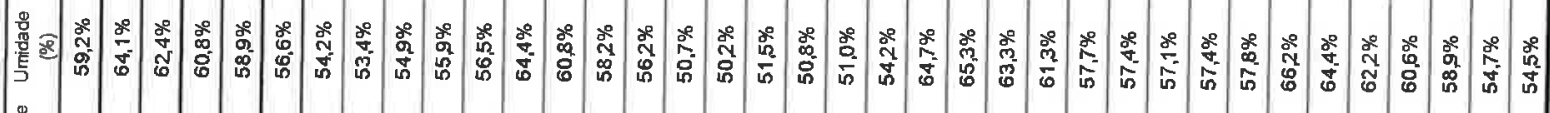

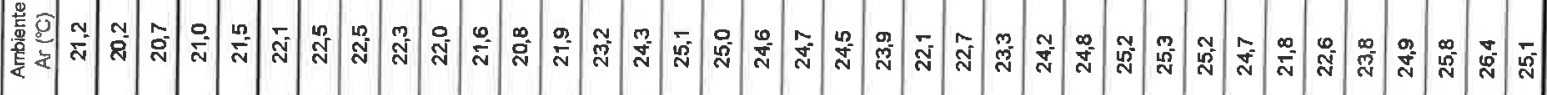

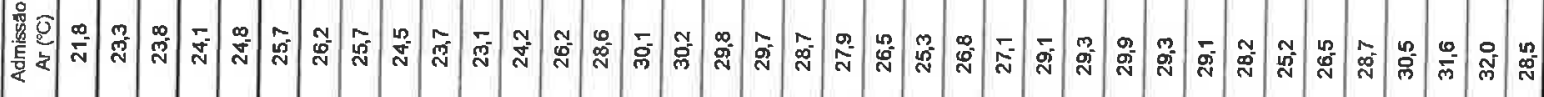

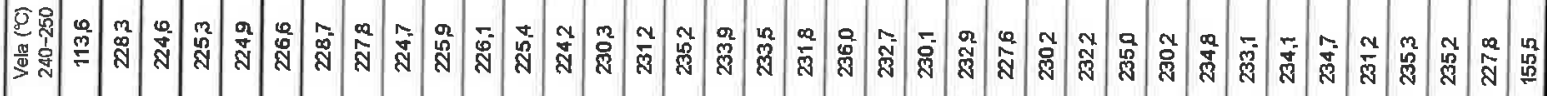

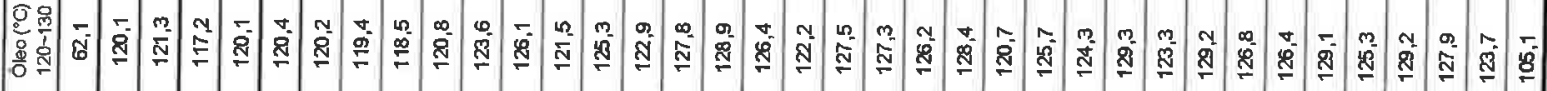

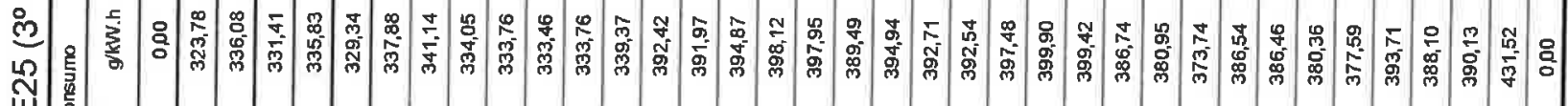

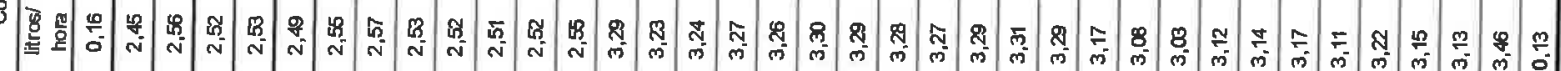

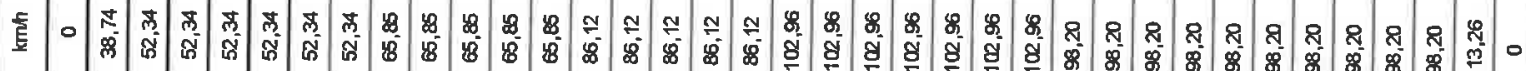

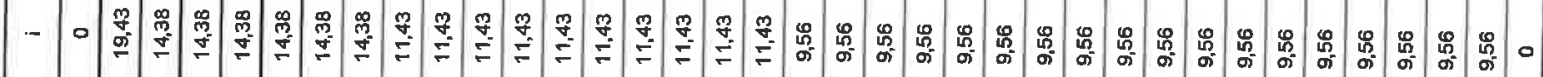

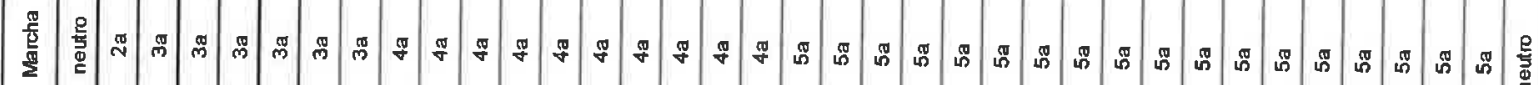

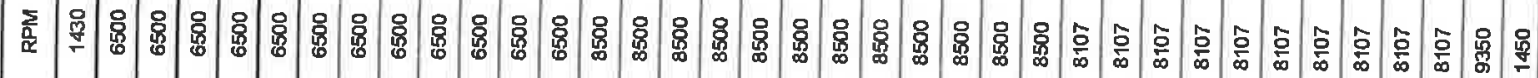
窟舀

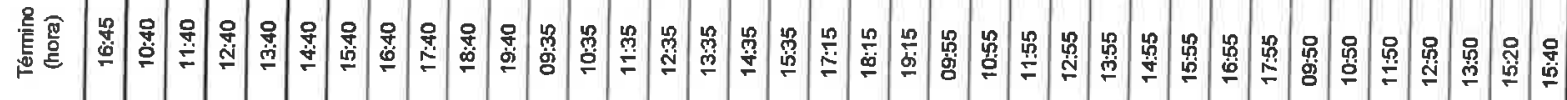

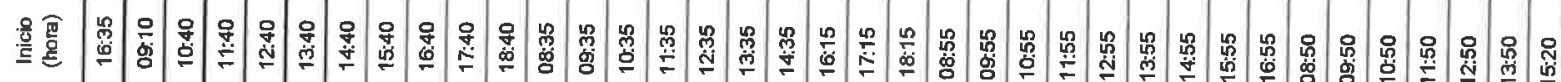

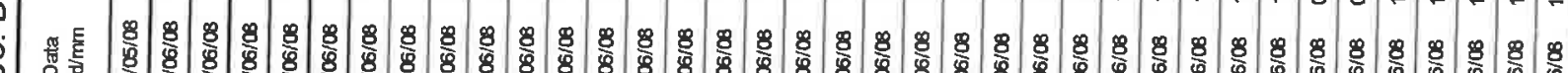

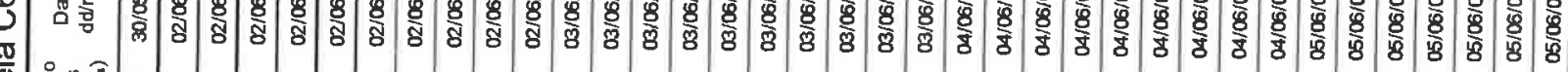




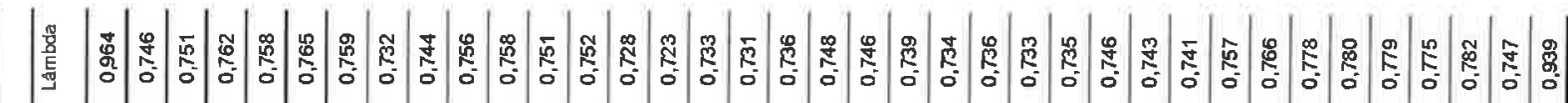

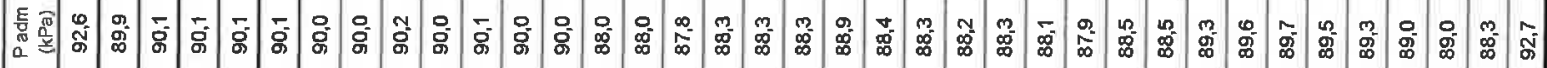

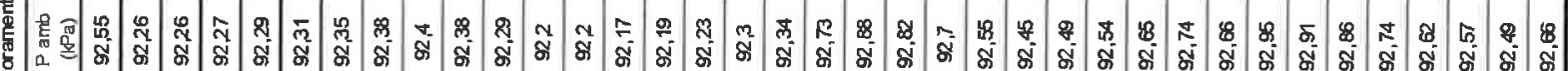
产

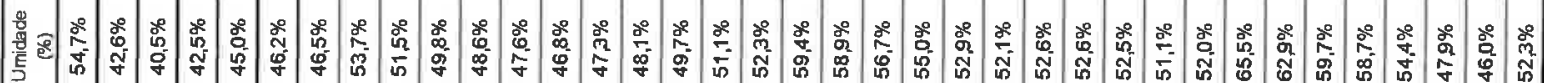

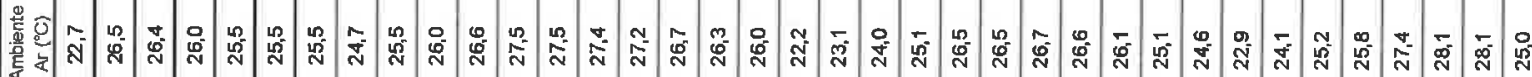

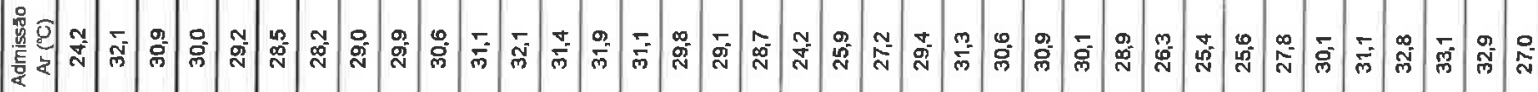

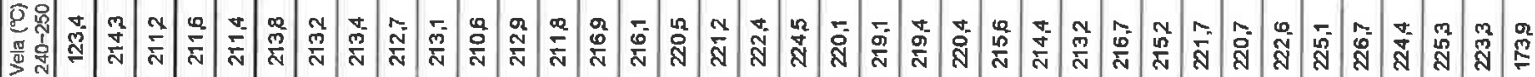

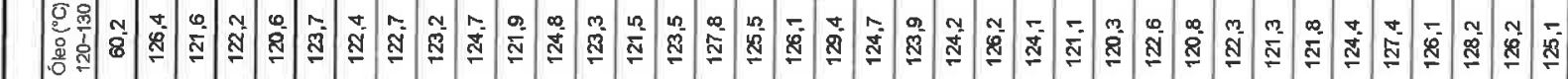

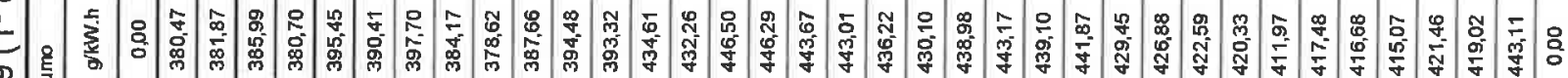
0 वे

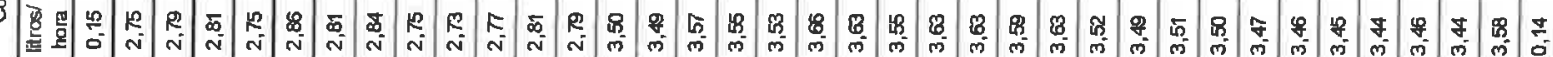

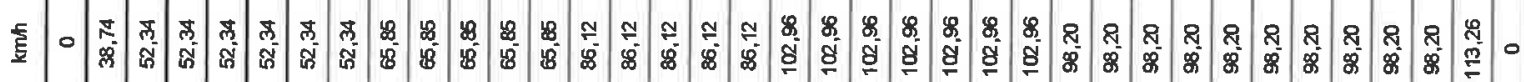

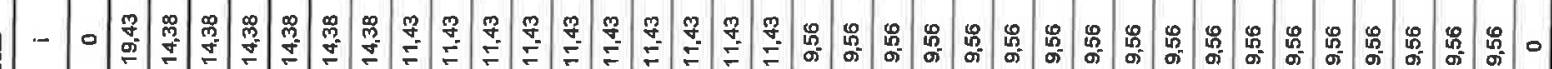

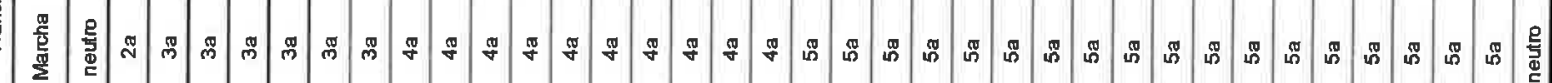

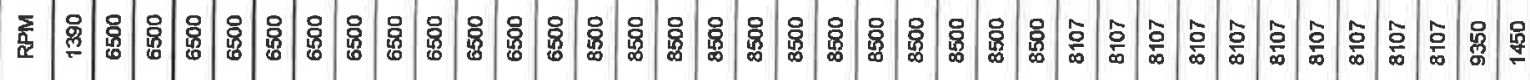
急

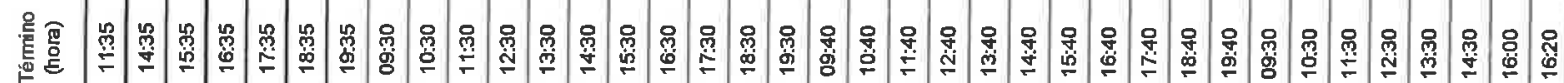

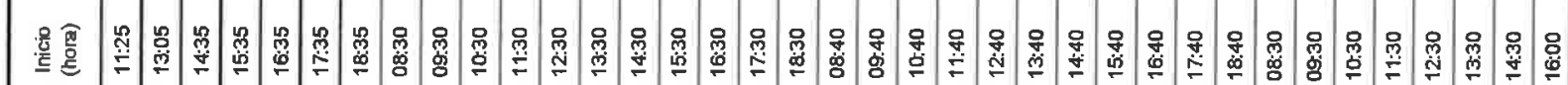

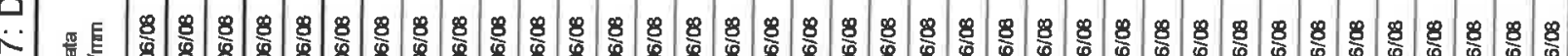

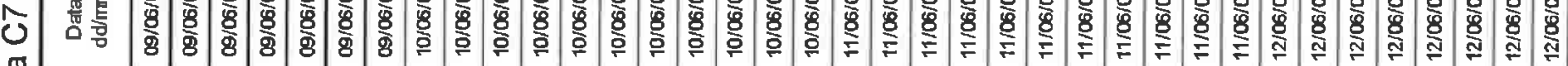

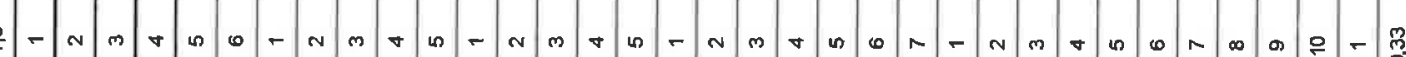




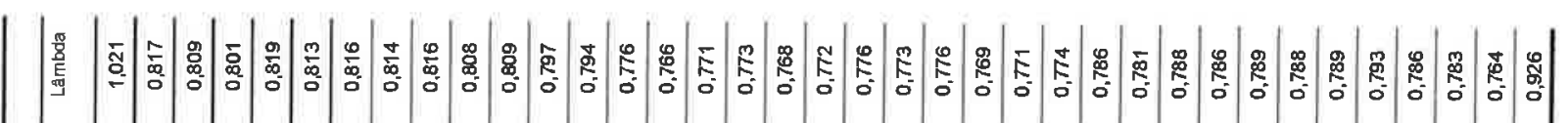

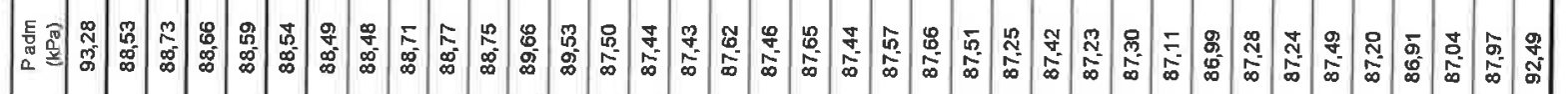
을

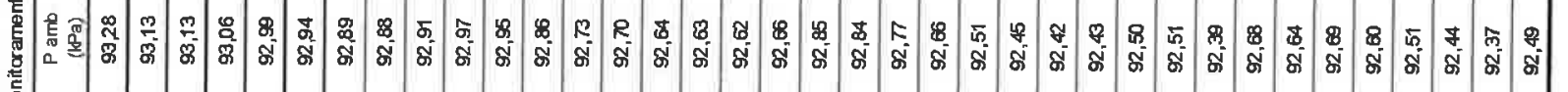

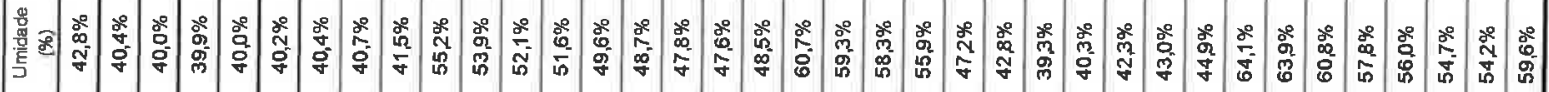

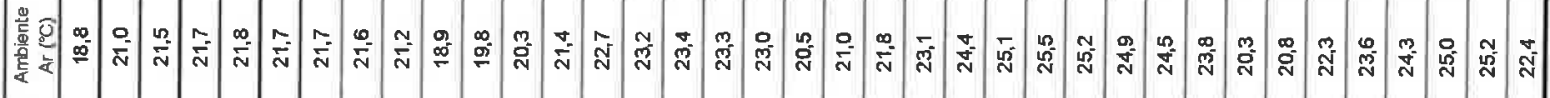

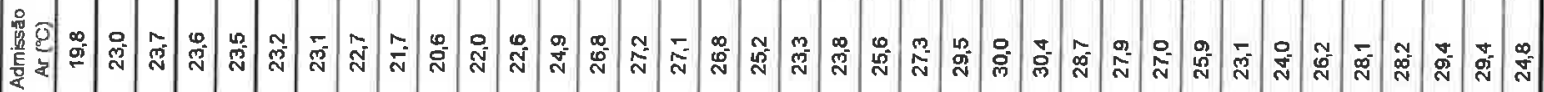

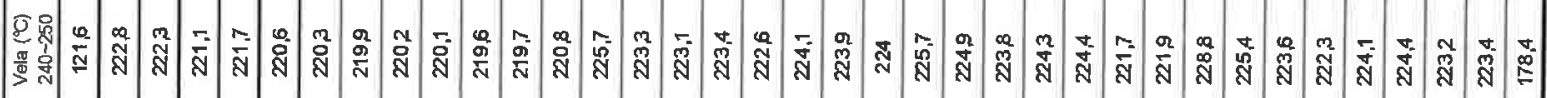

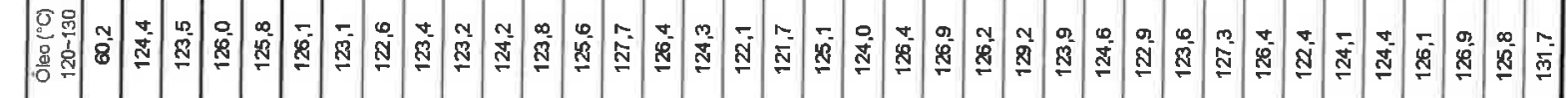

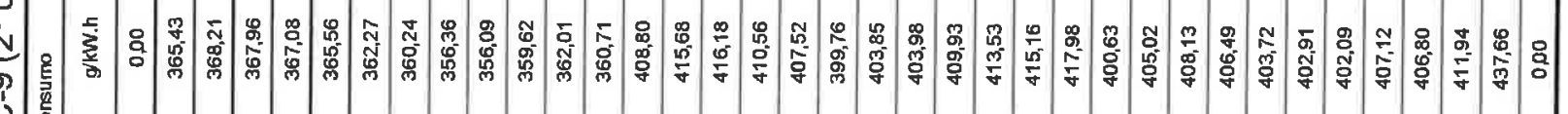

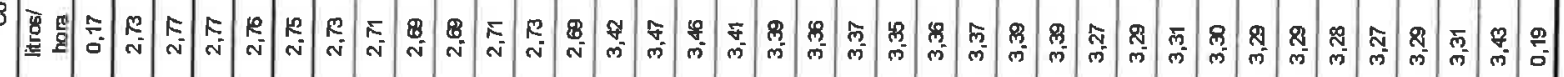

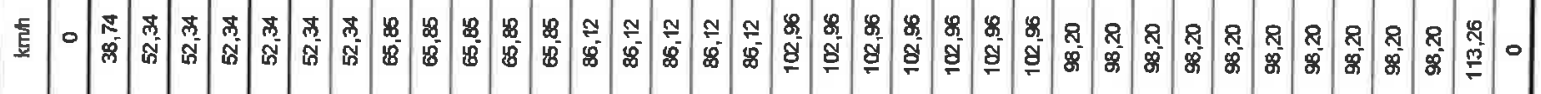

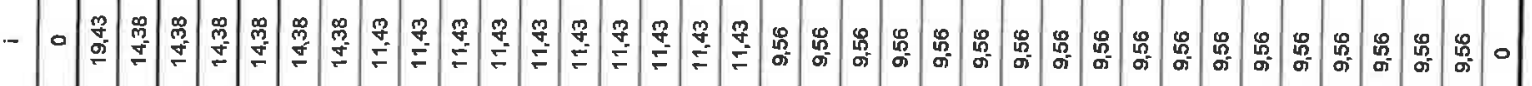

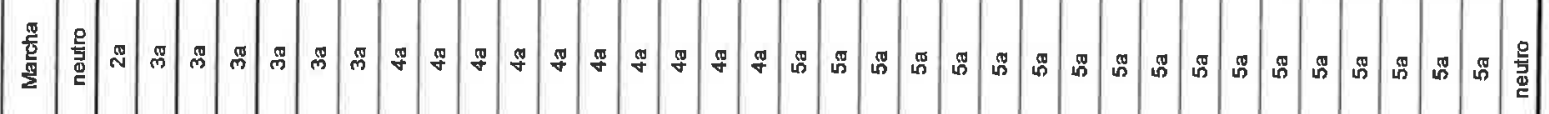

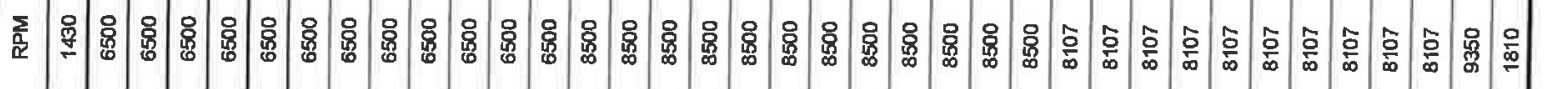
害 8 ठ

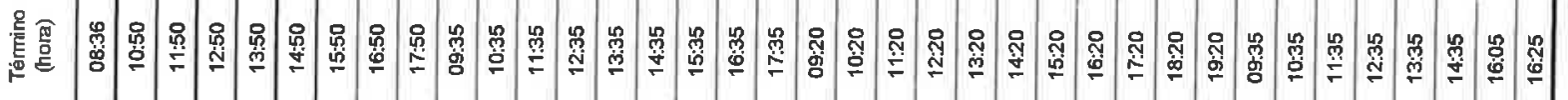

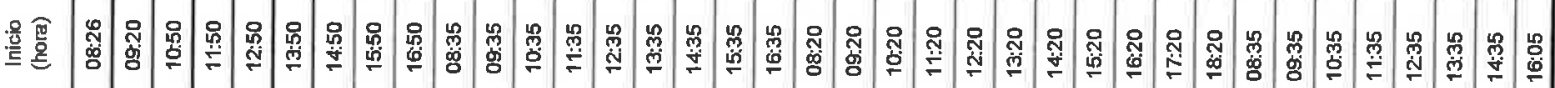

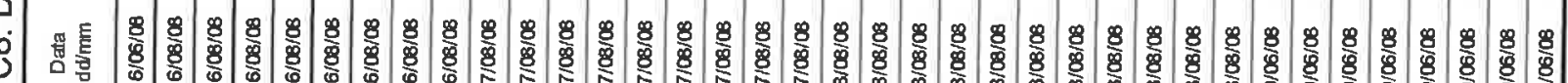
要 


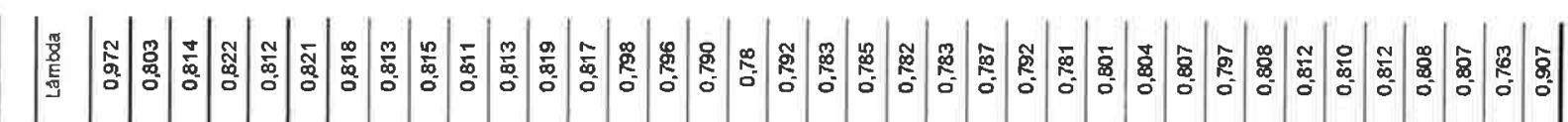

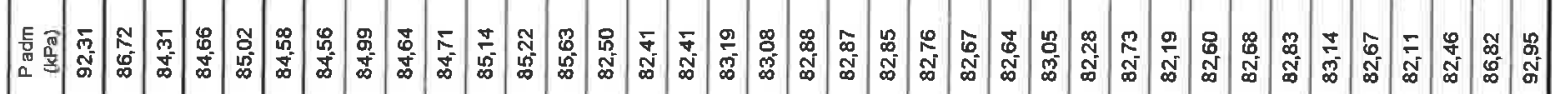

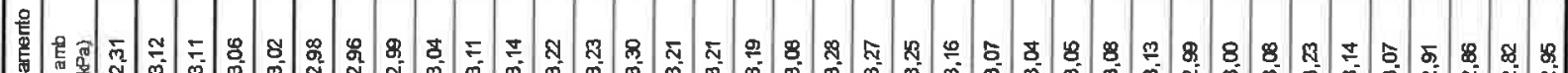

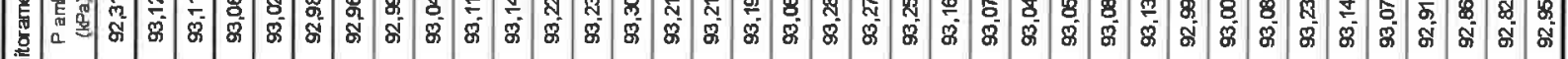
旁

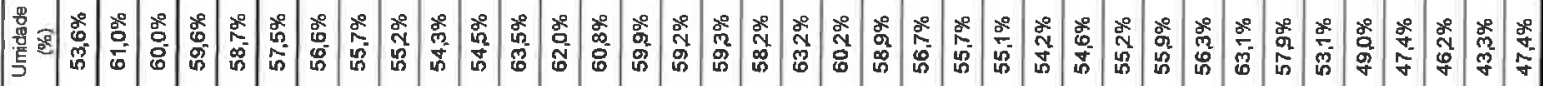

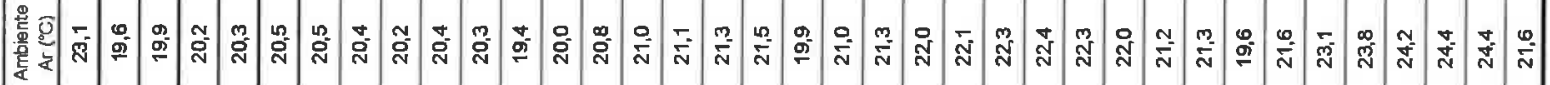

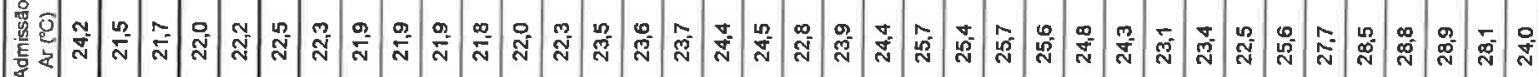

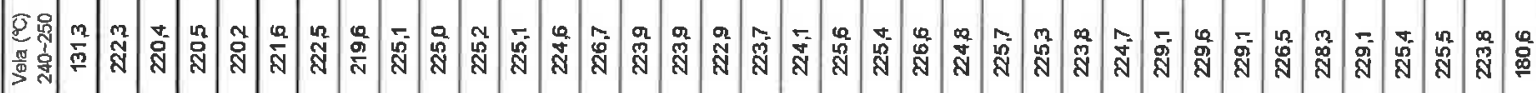

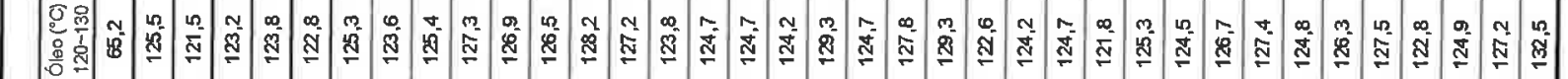

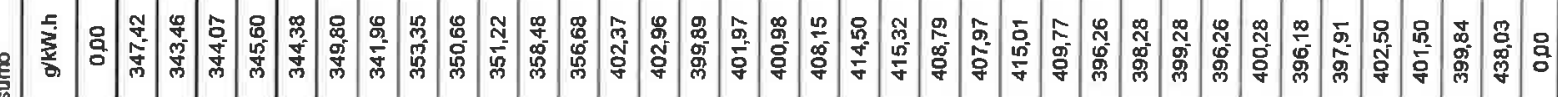
悌

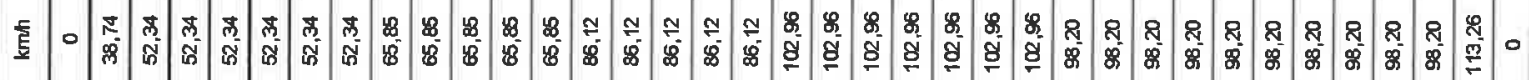

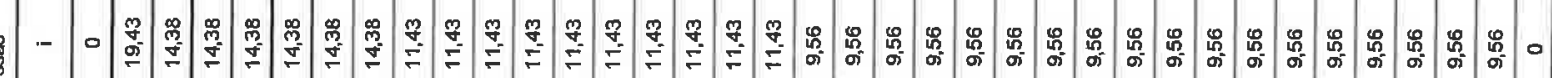

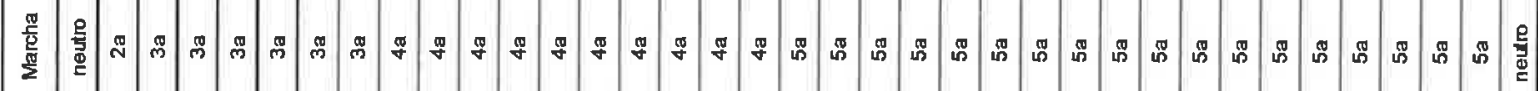

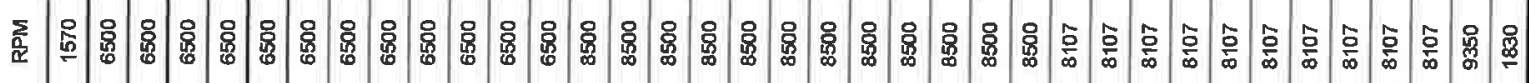
㵊

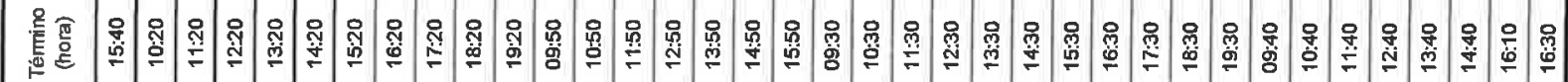

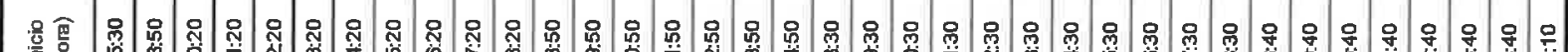

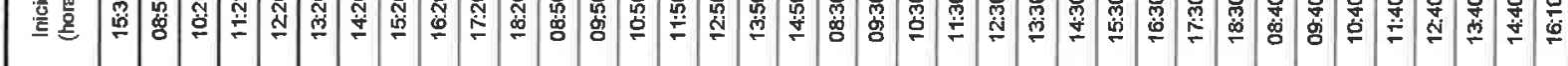
茼 \begin{tabular}{ll}
\hline \\
0
\end{tabular}

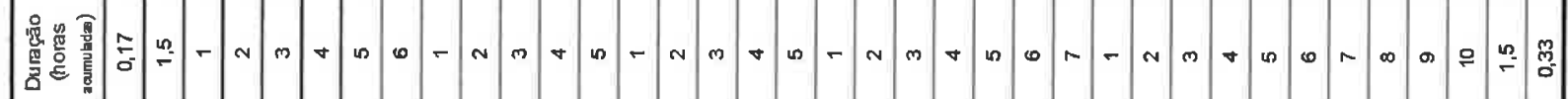




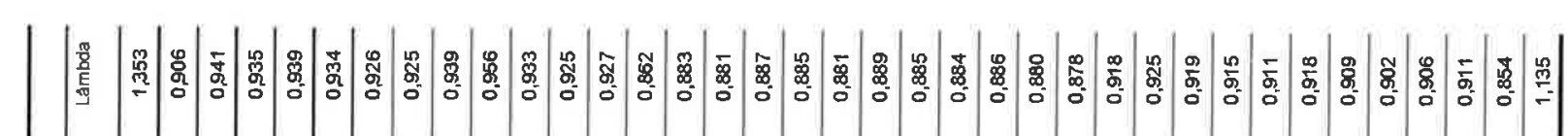

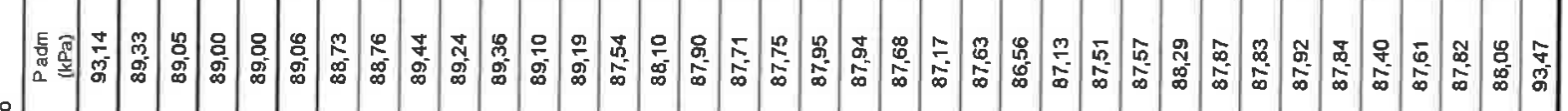

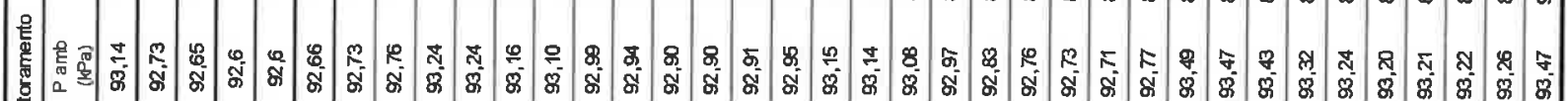

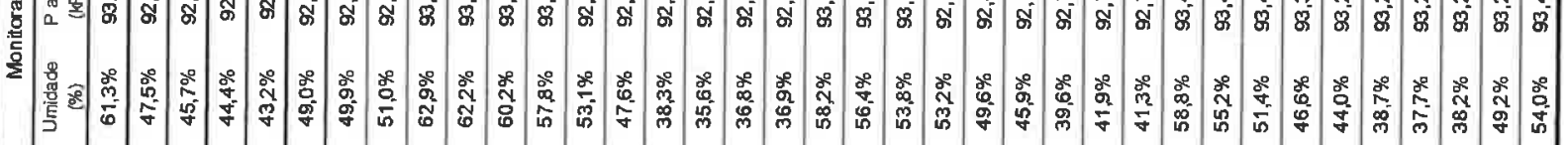
ใดำ

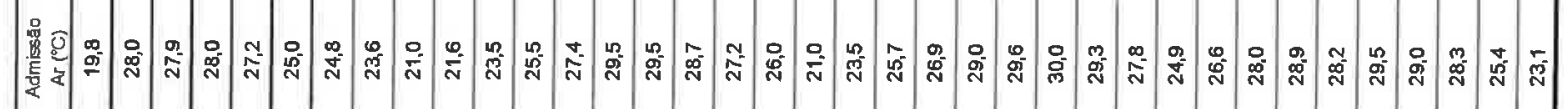

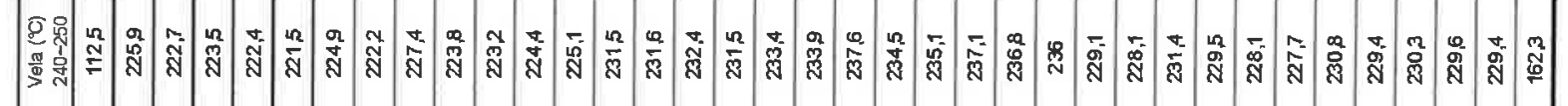

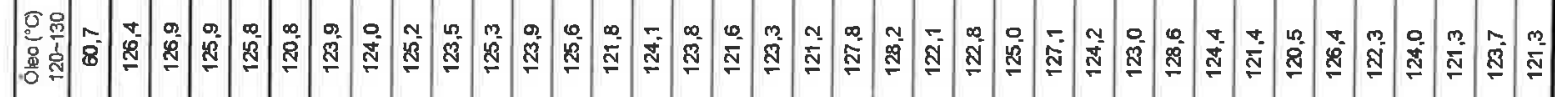

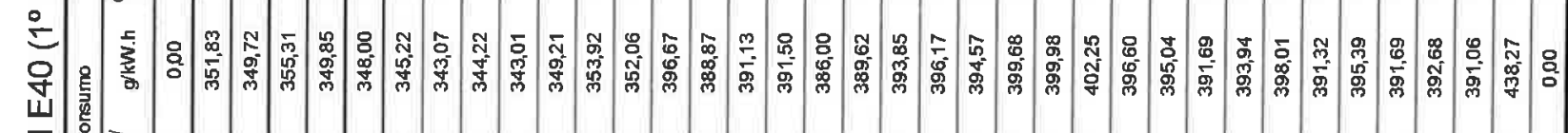

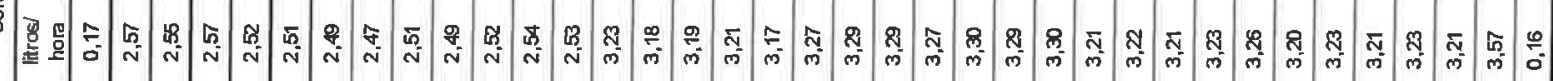
吉

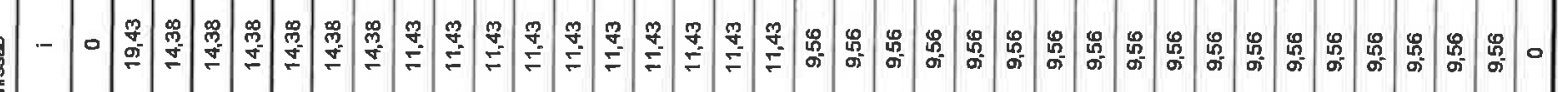

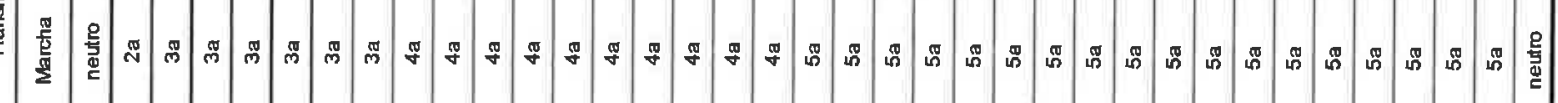

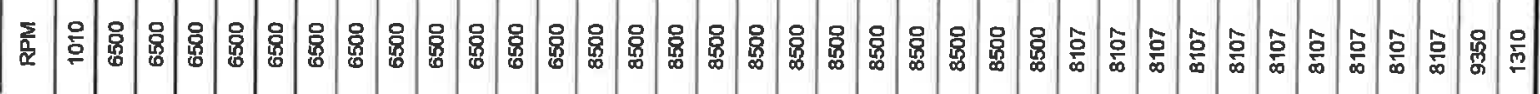

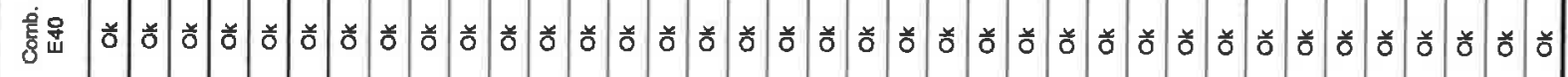

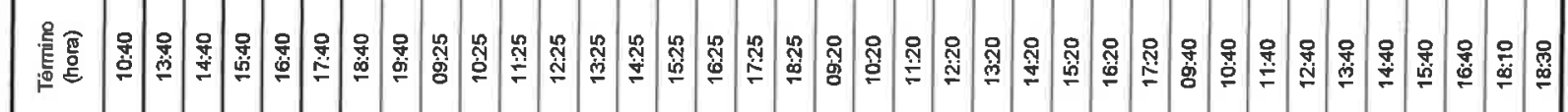

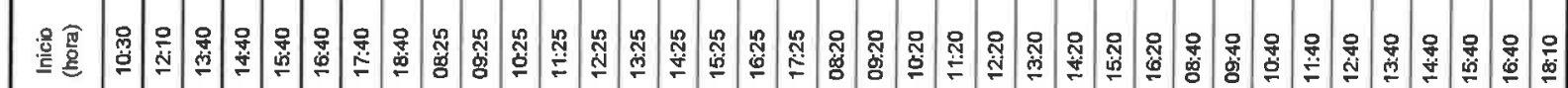

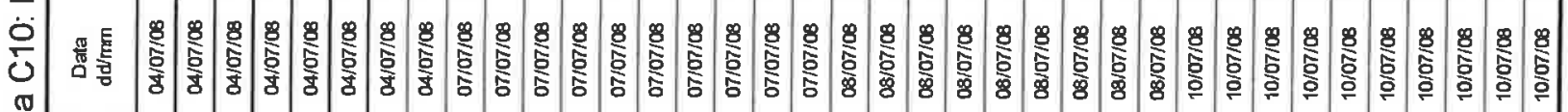
$\stackrel{\frac{\pi}{0}}{\frac{\pi}{\infty}}$

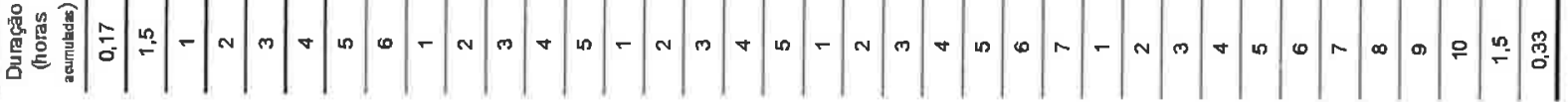


|

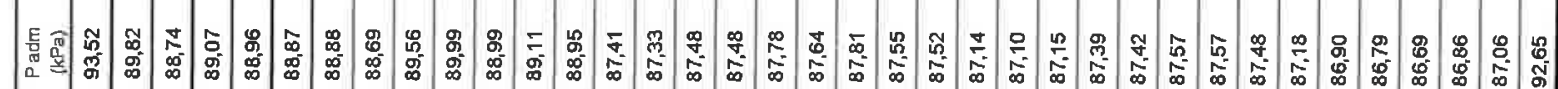

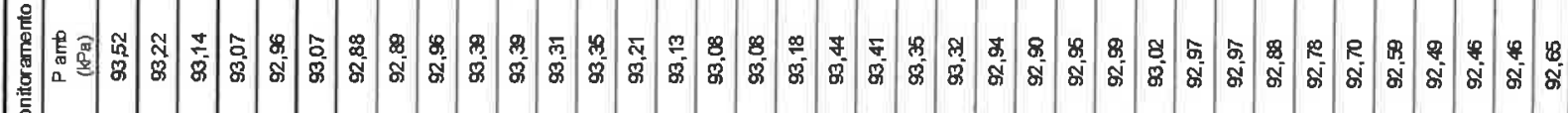

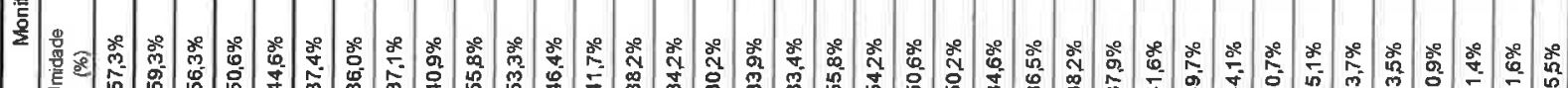

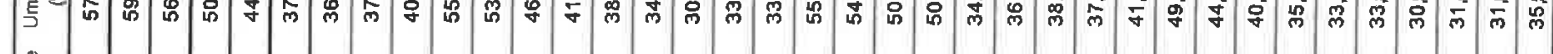

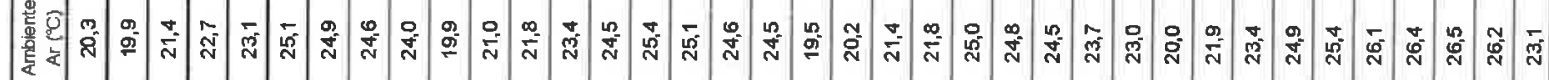

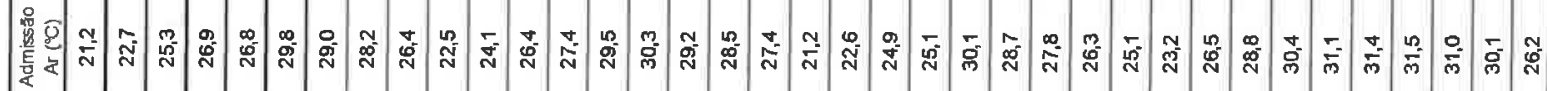

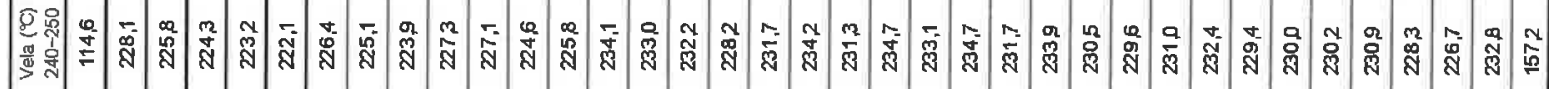

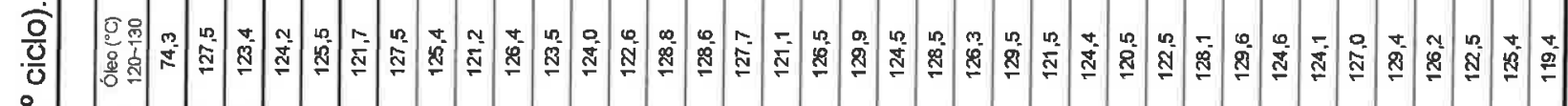

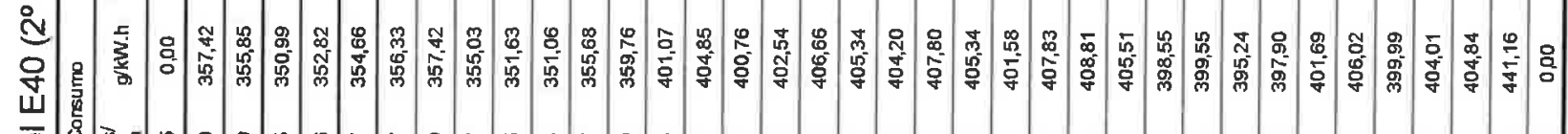

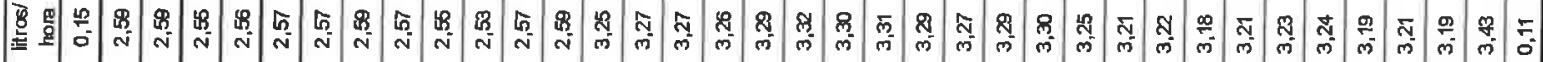

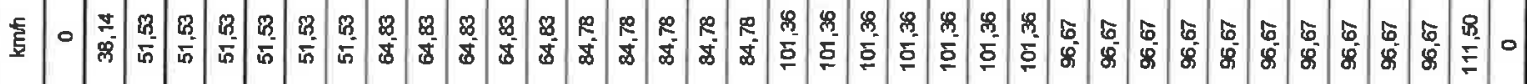

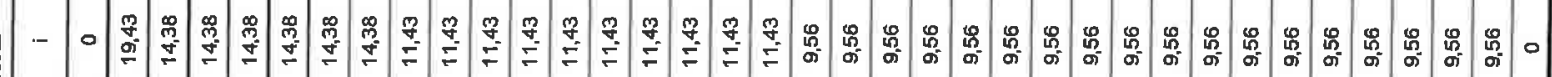

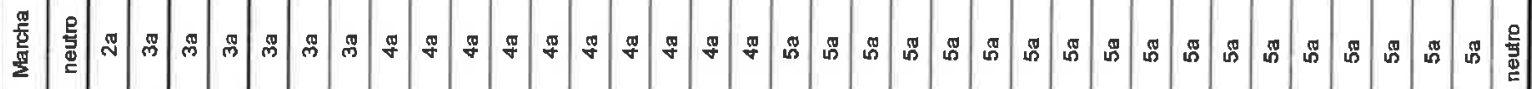

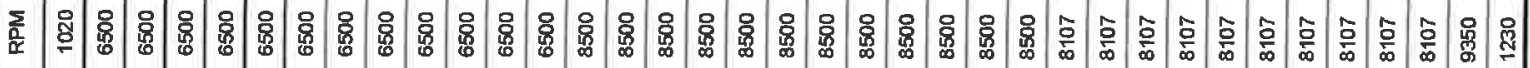

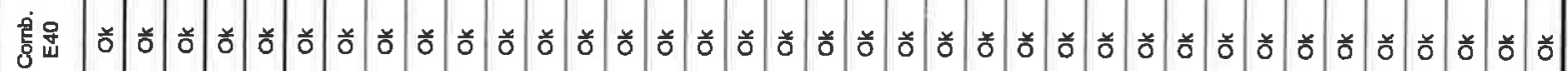

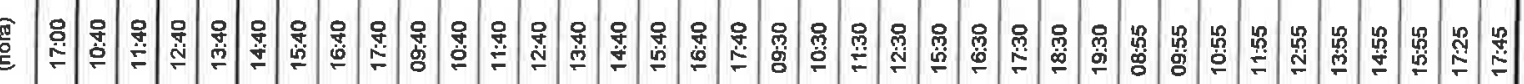

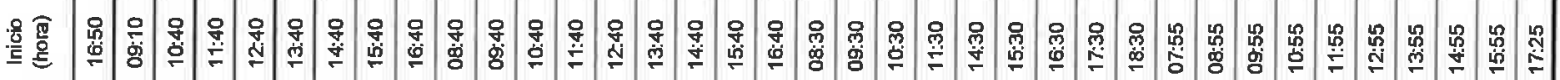




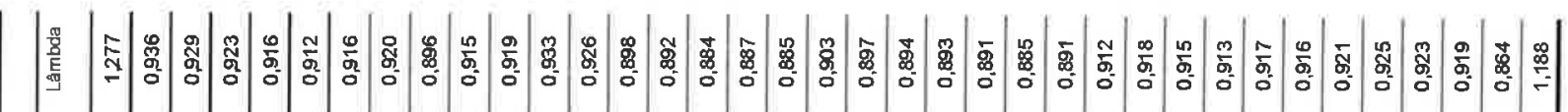

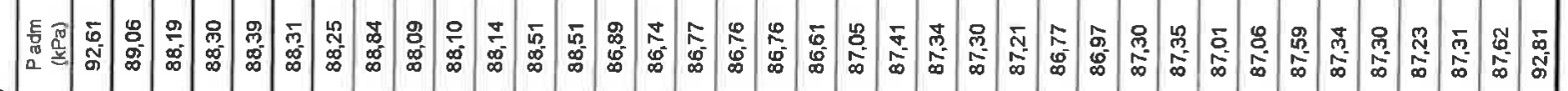

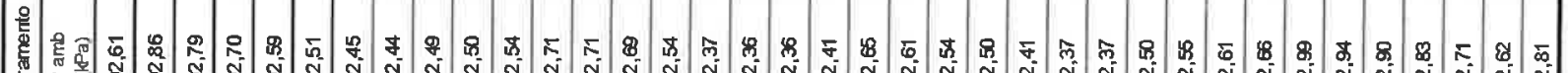

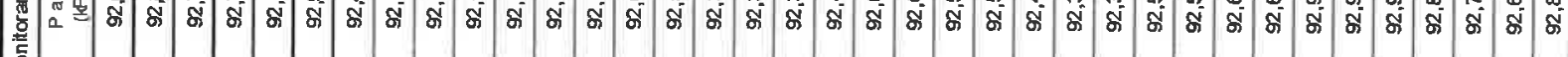

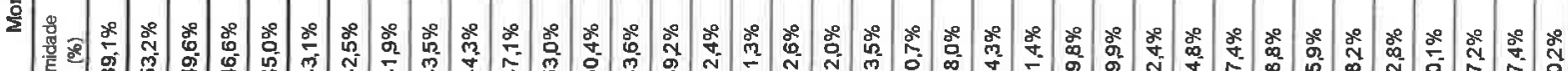

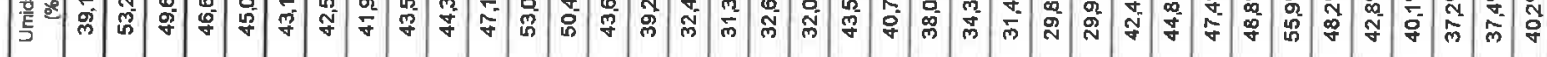

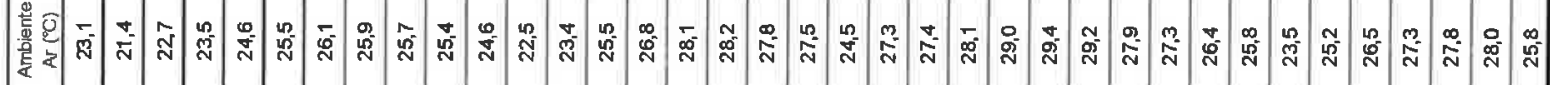

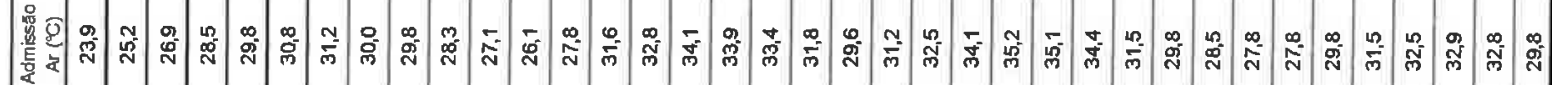

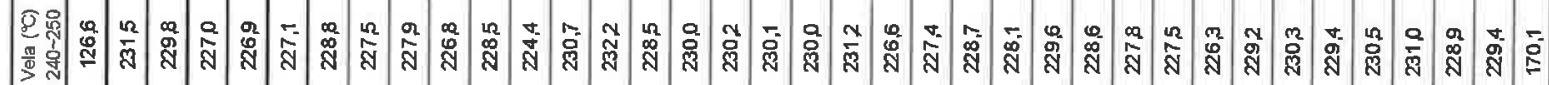

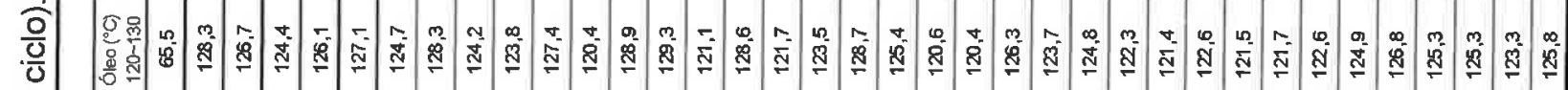

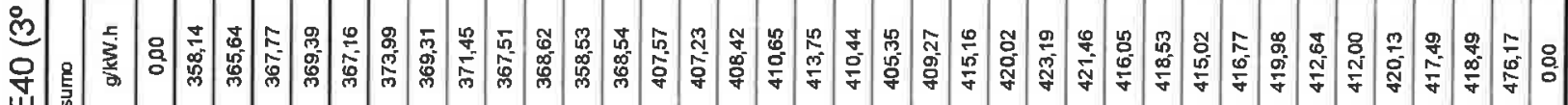

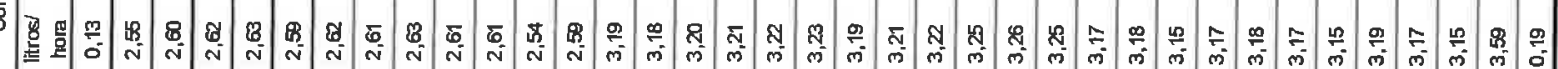

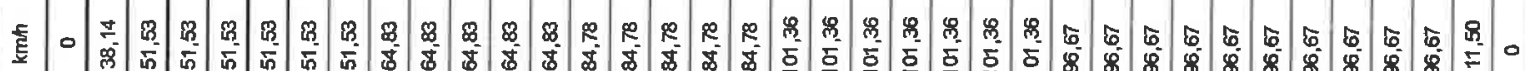

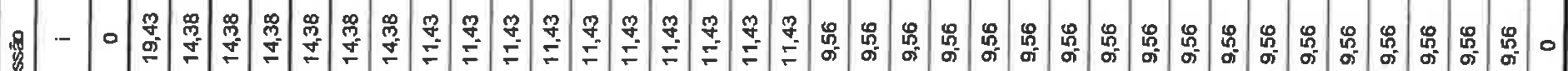

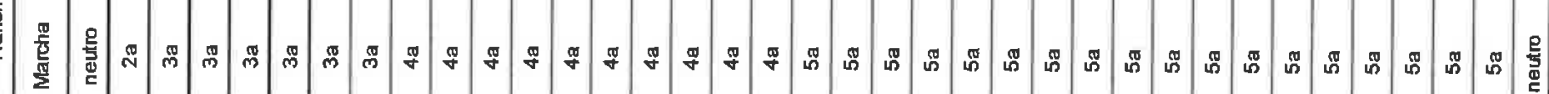

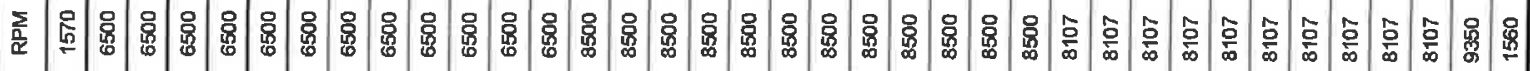

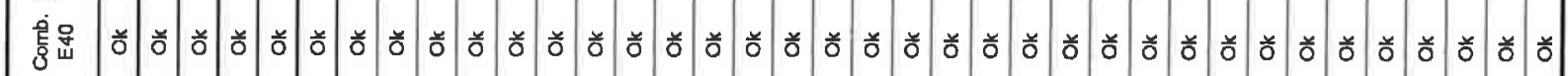

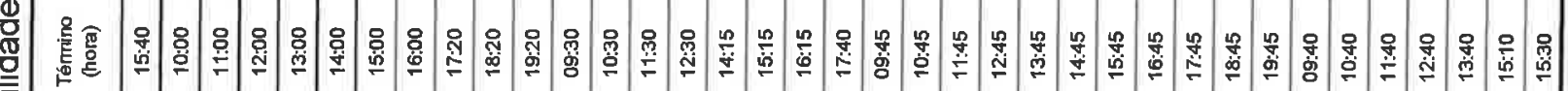

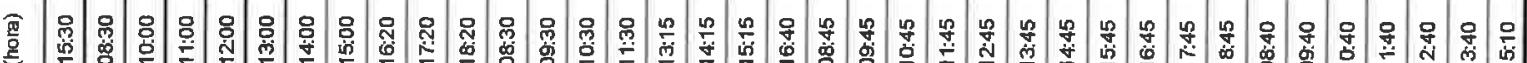
ป

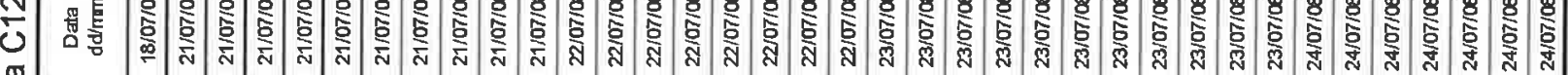
西 fo. - 


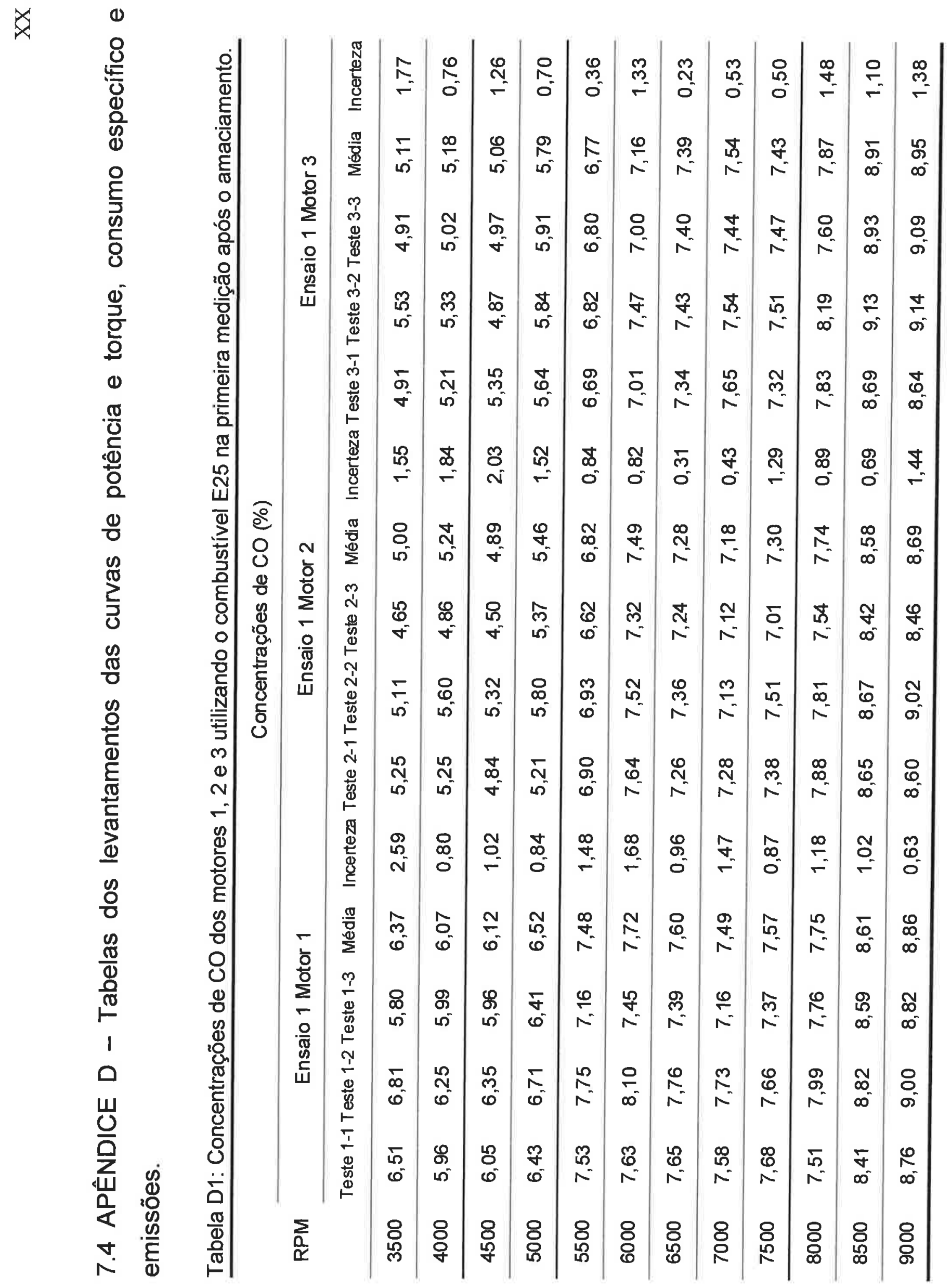


究

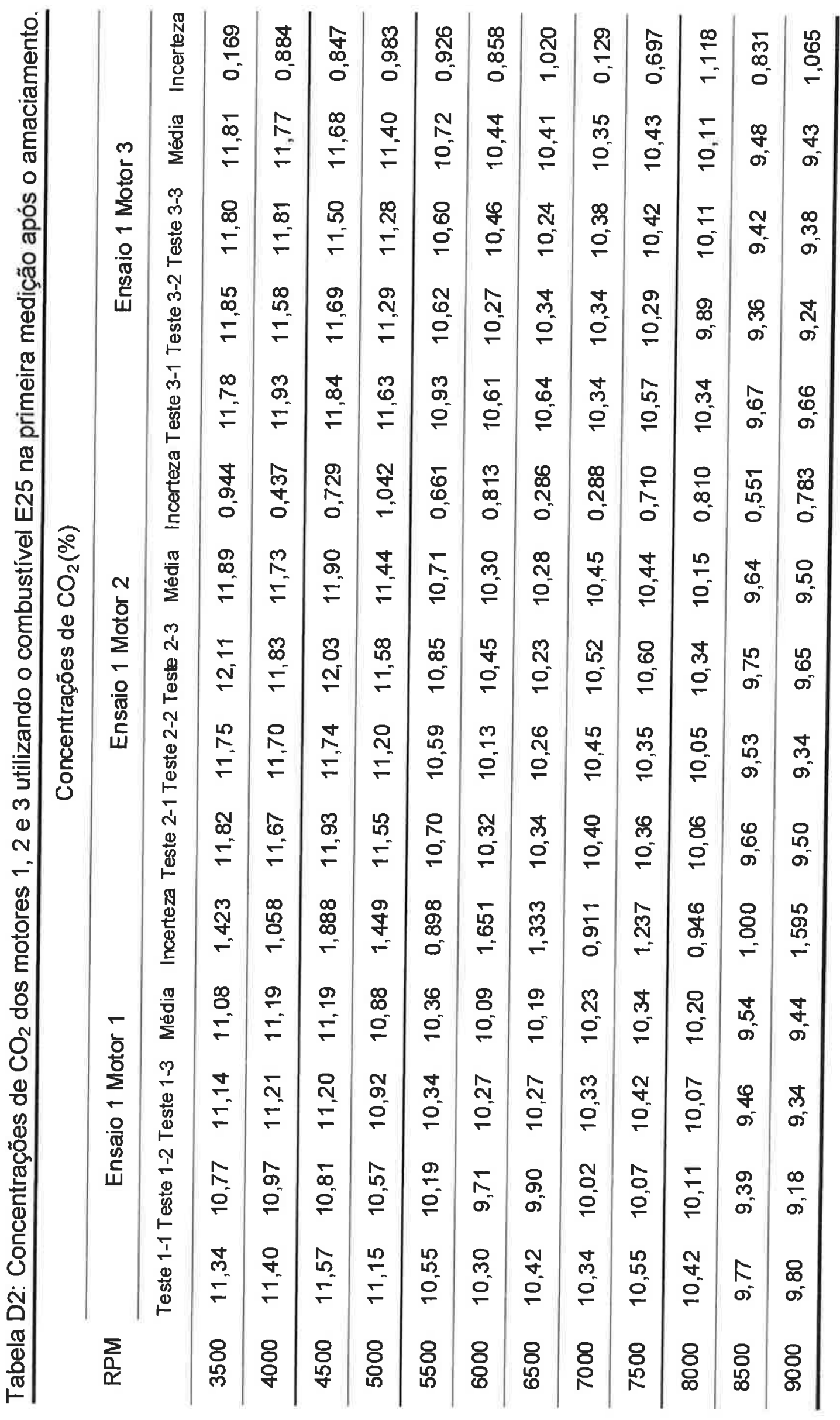


ㅋ.ㅅ․

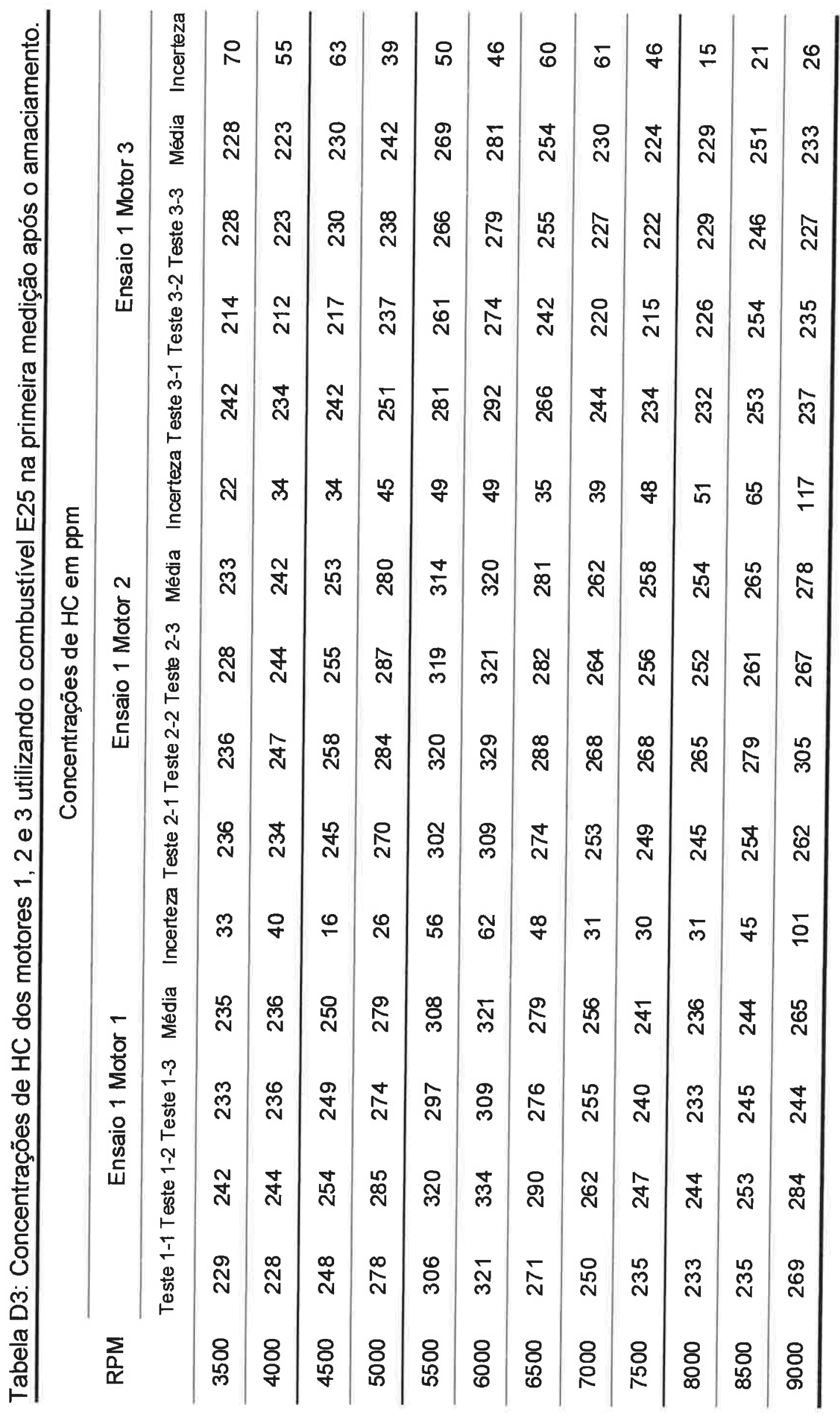




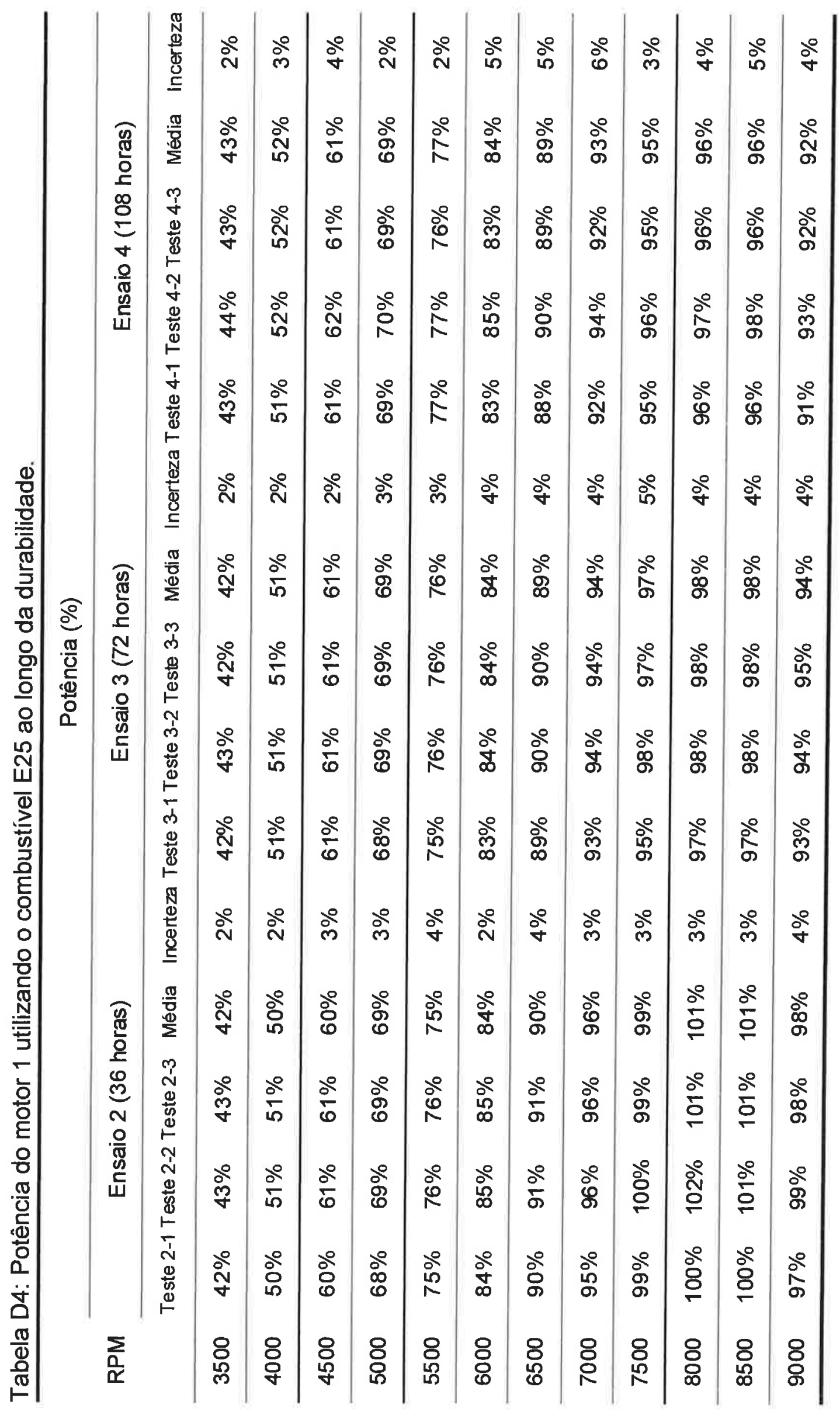


㞔

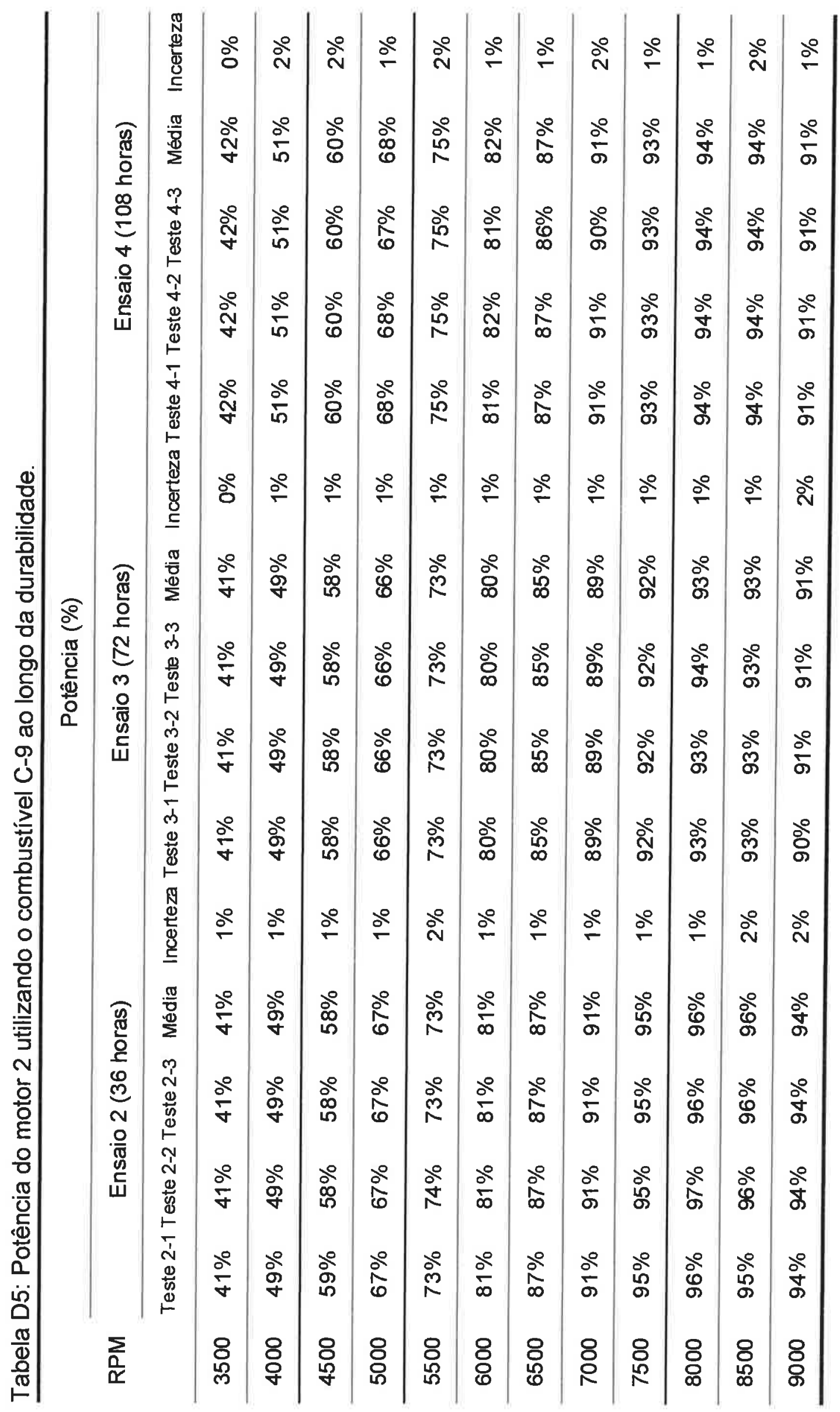


店

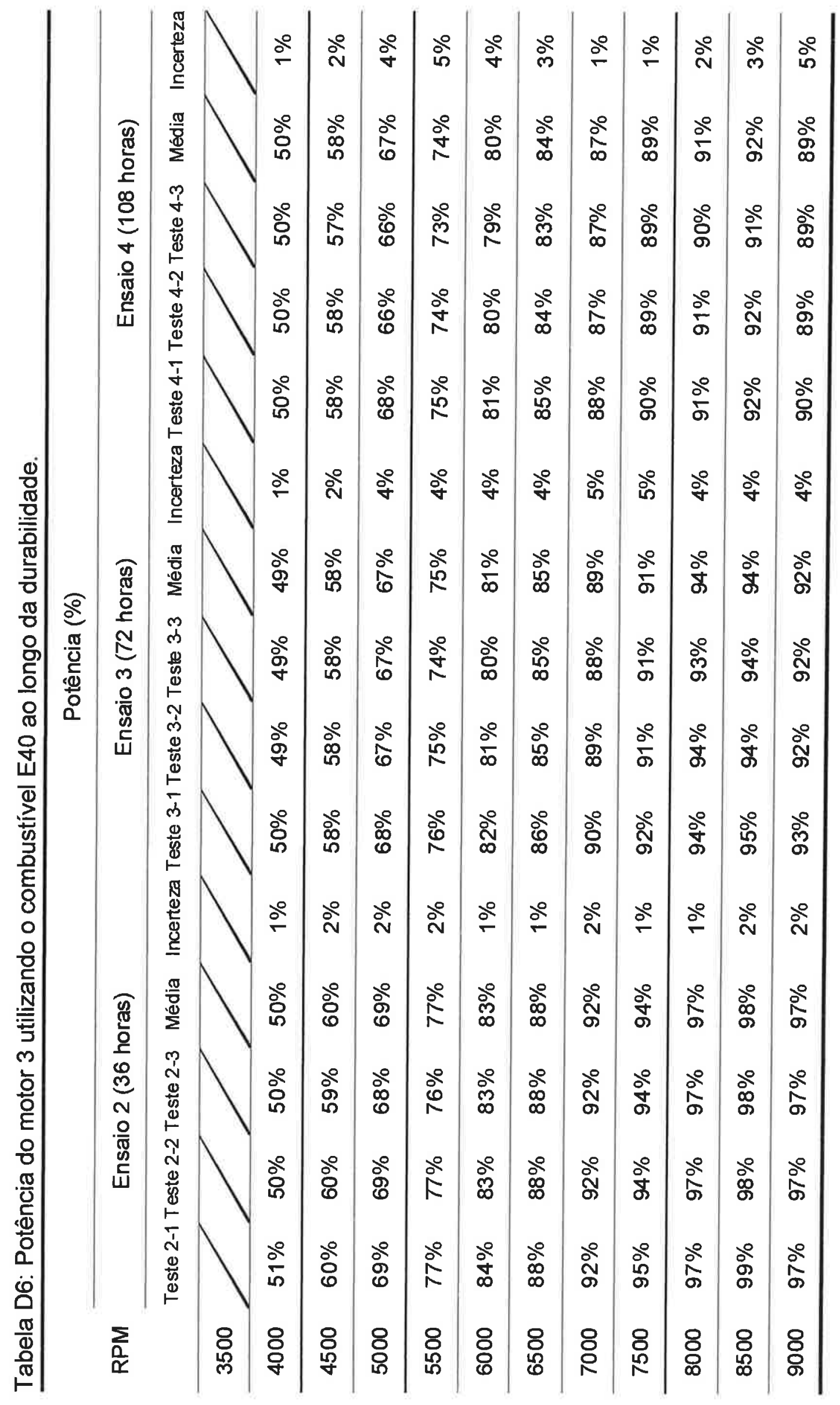




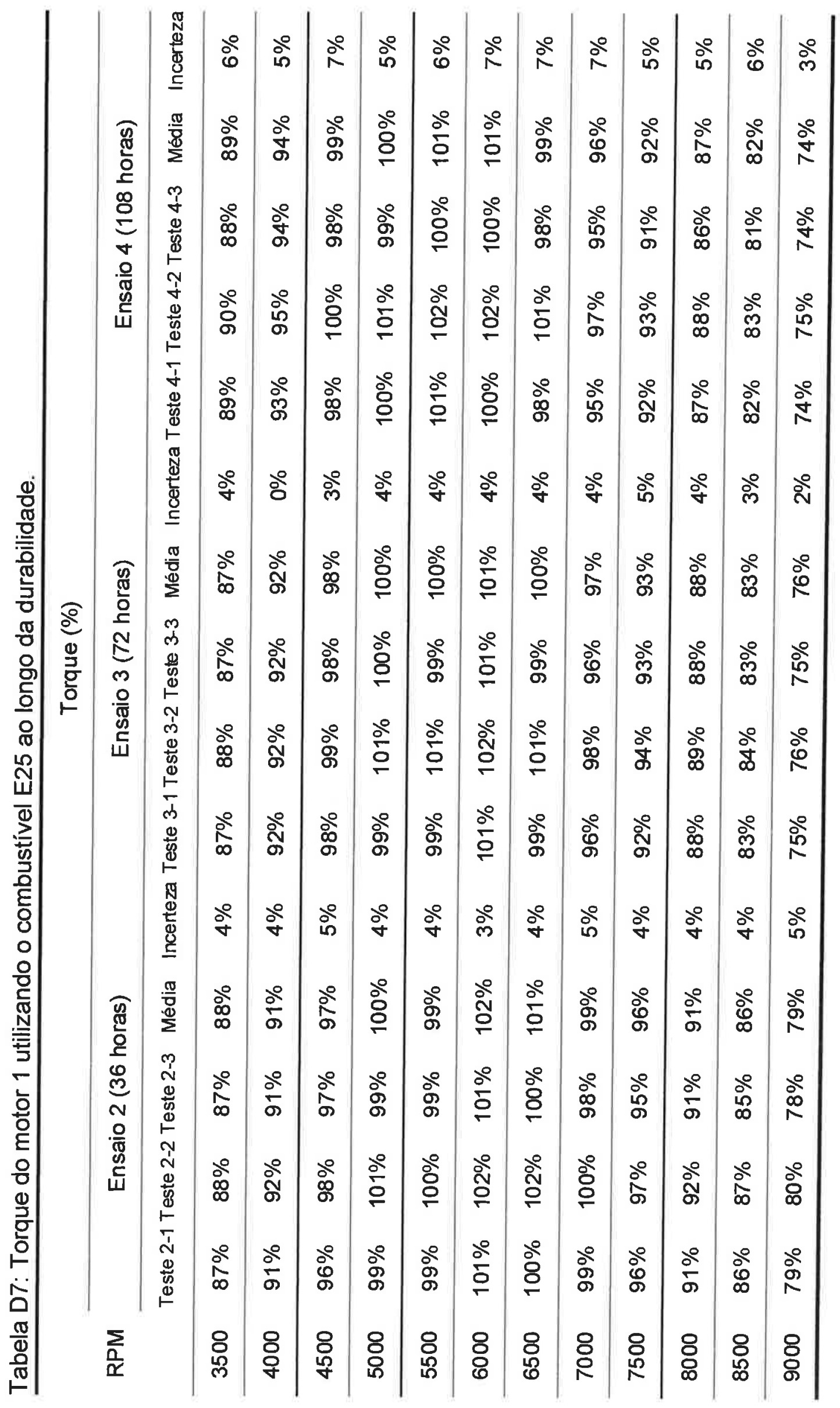




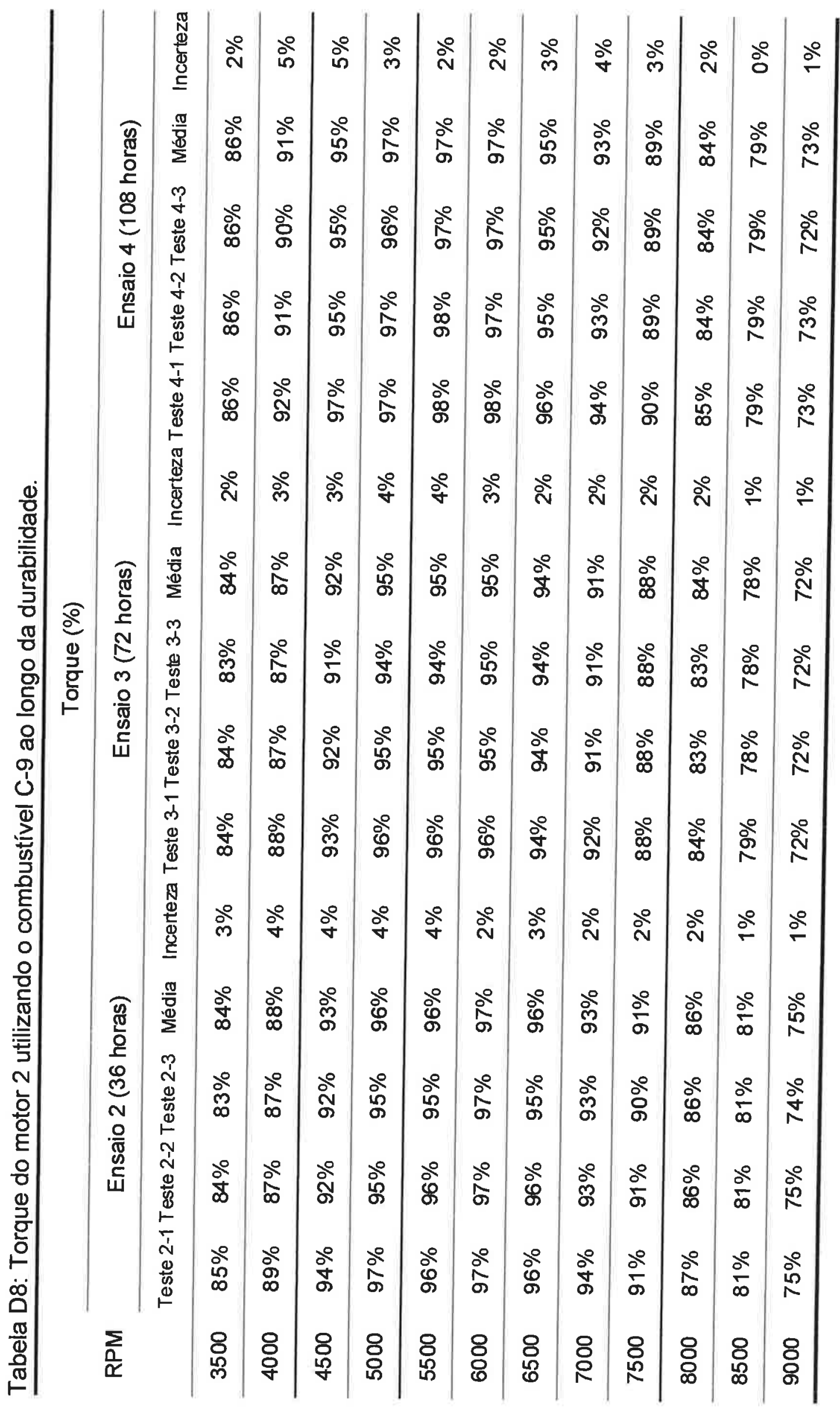




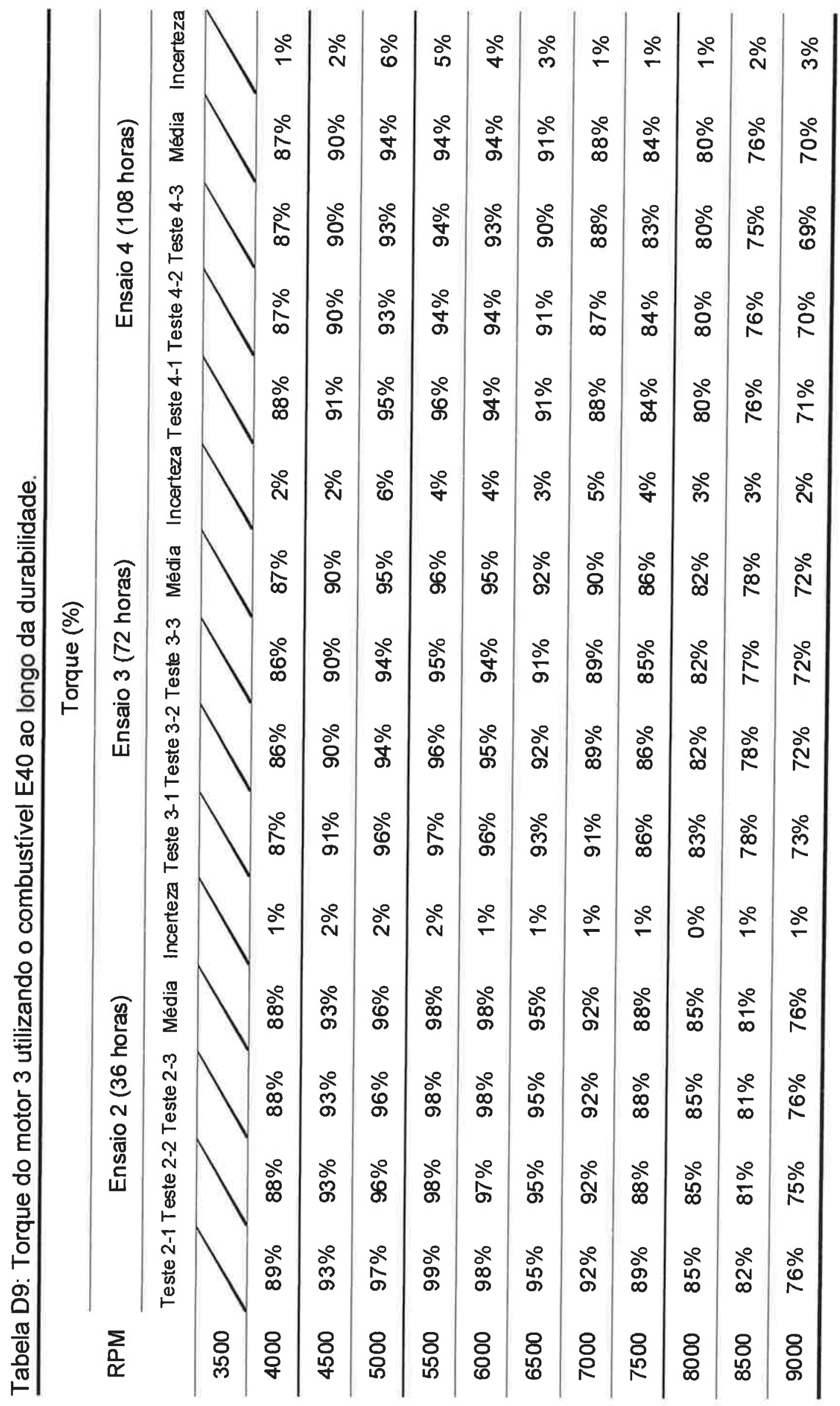


.

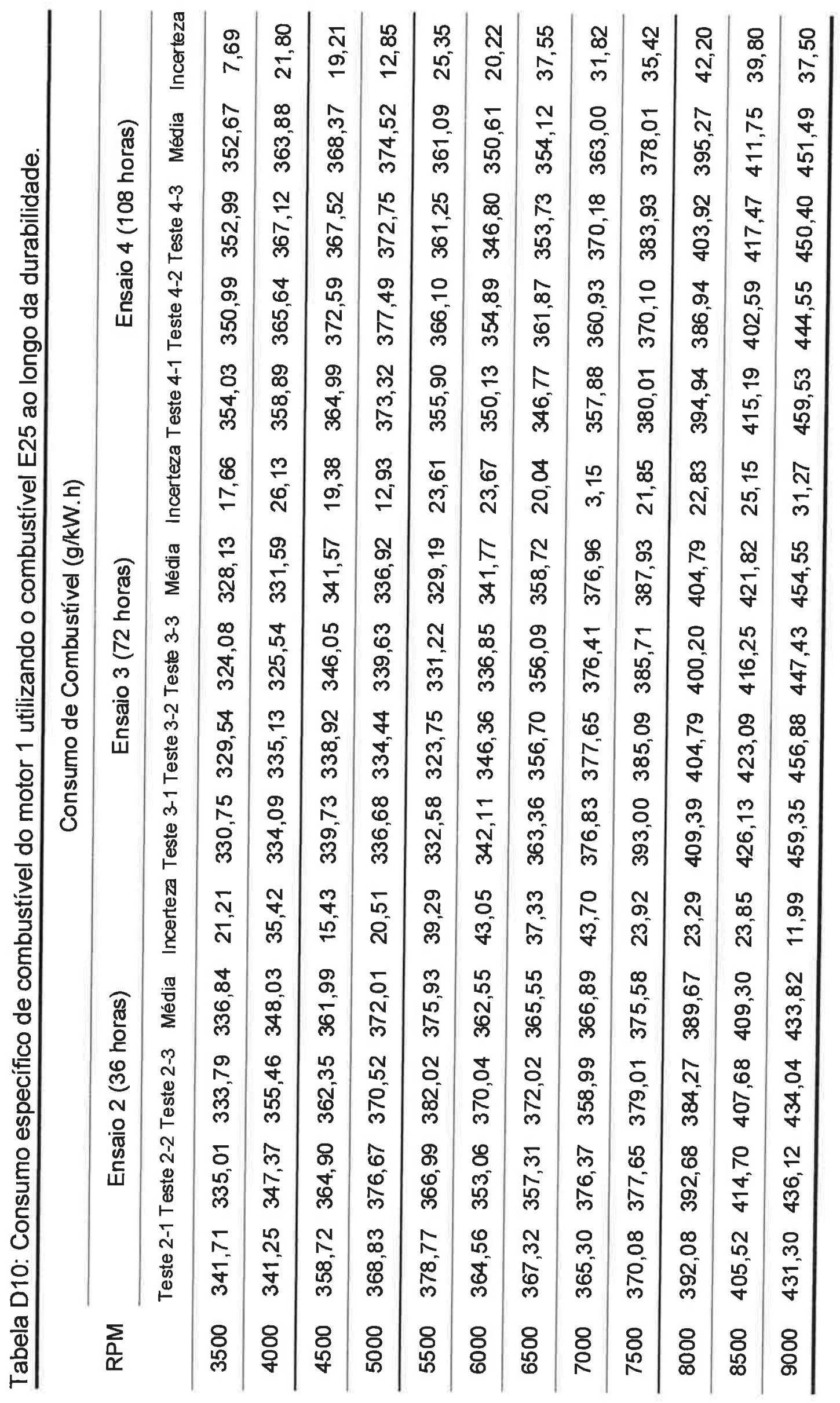




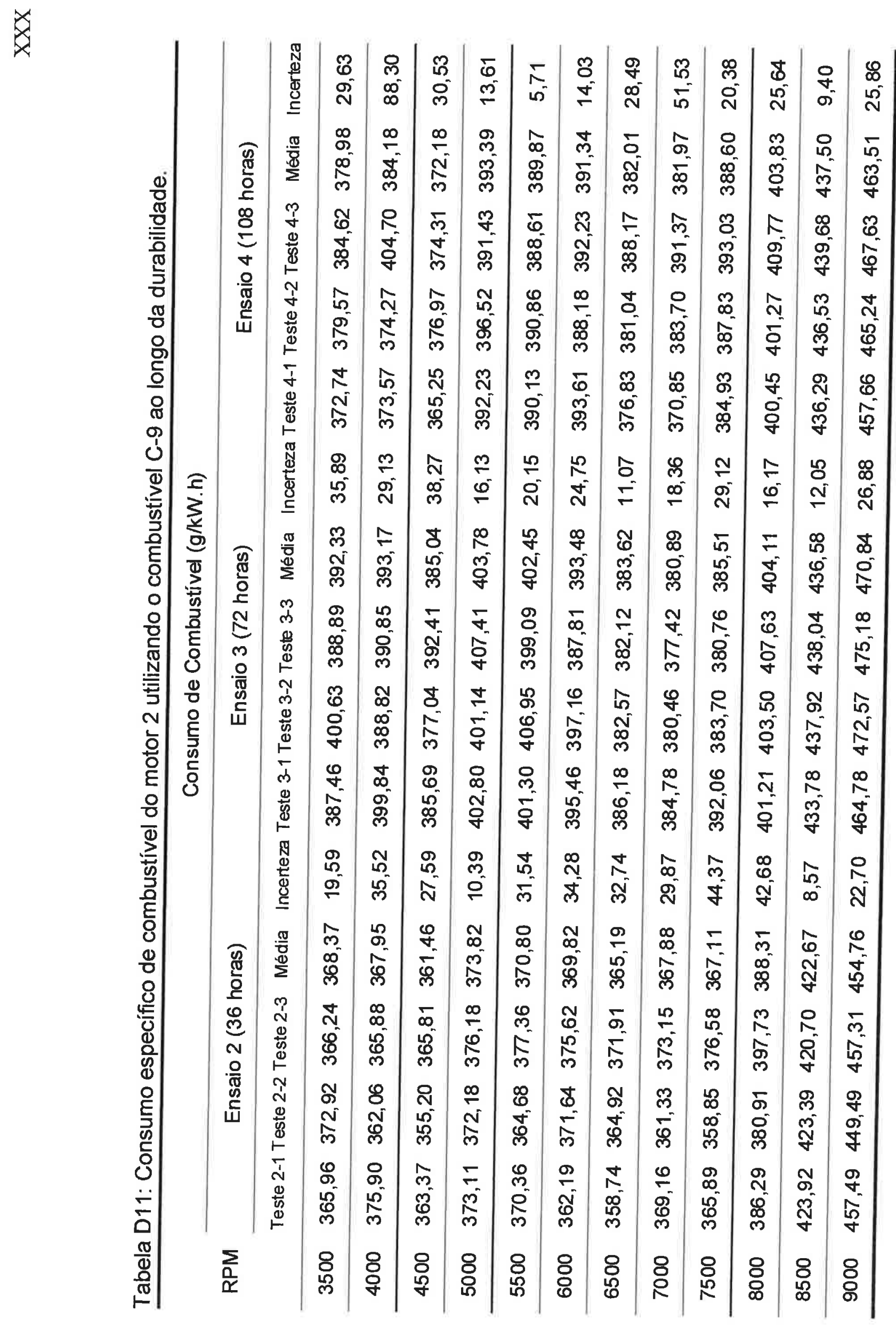




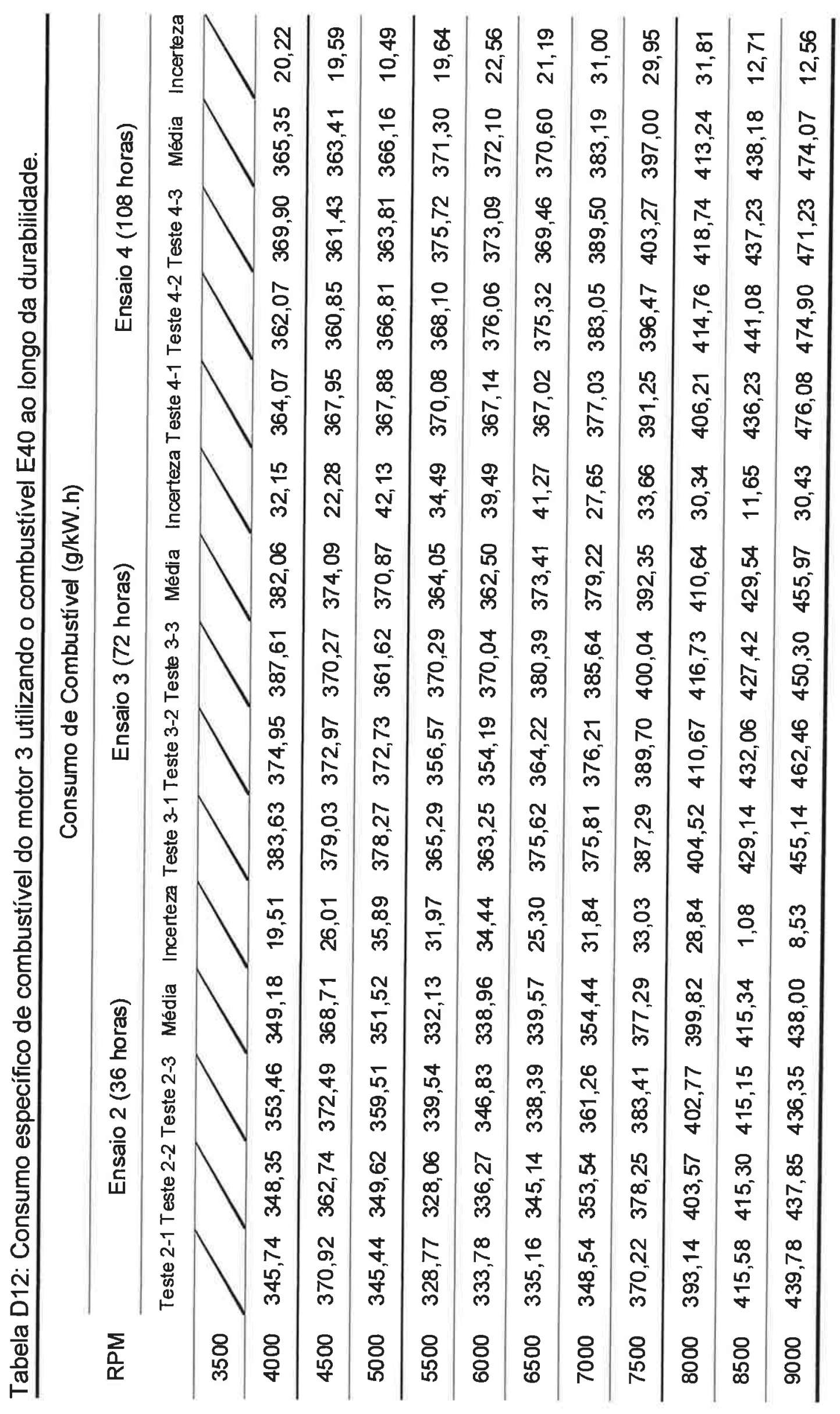




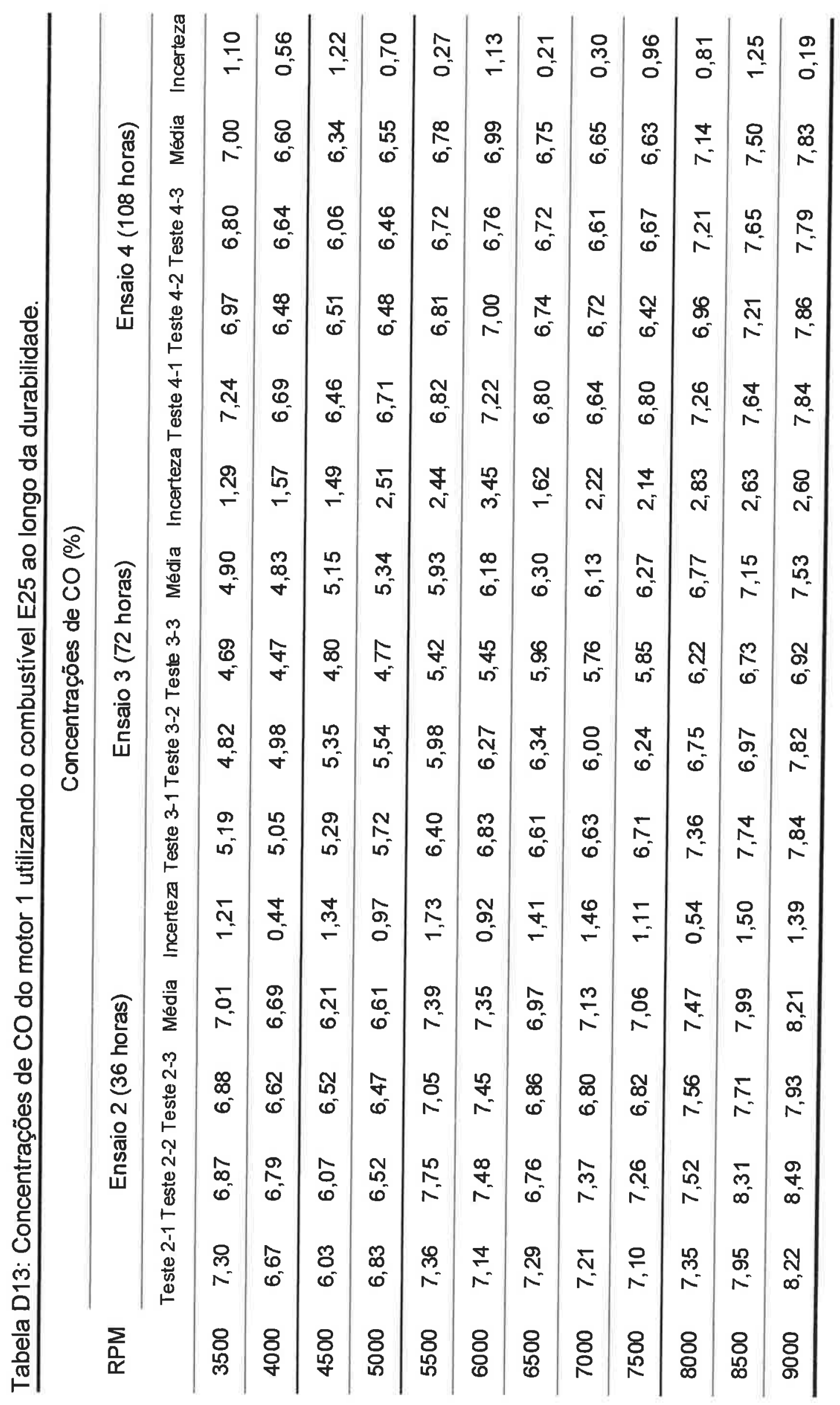




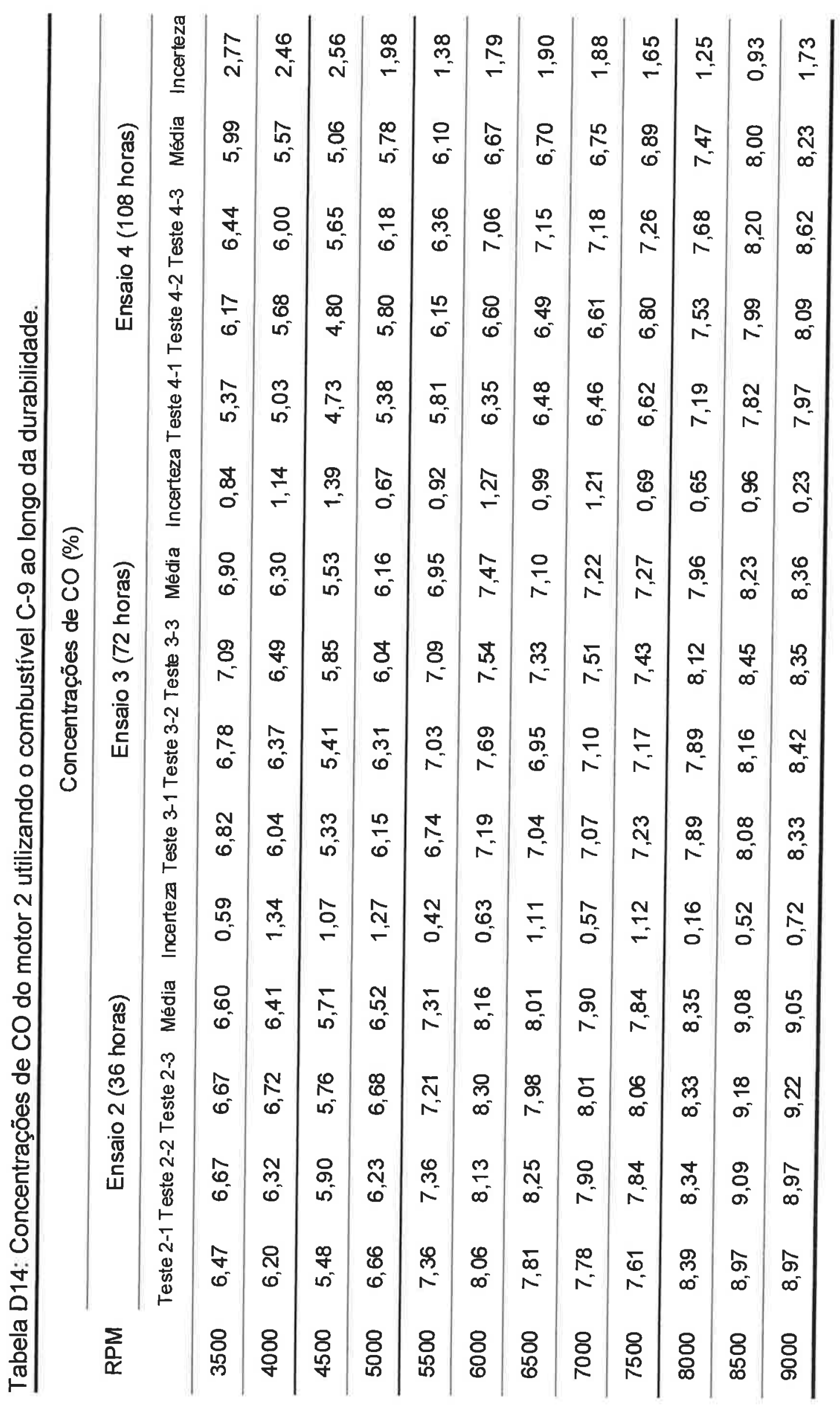




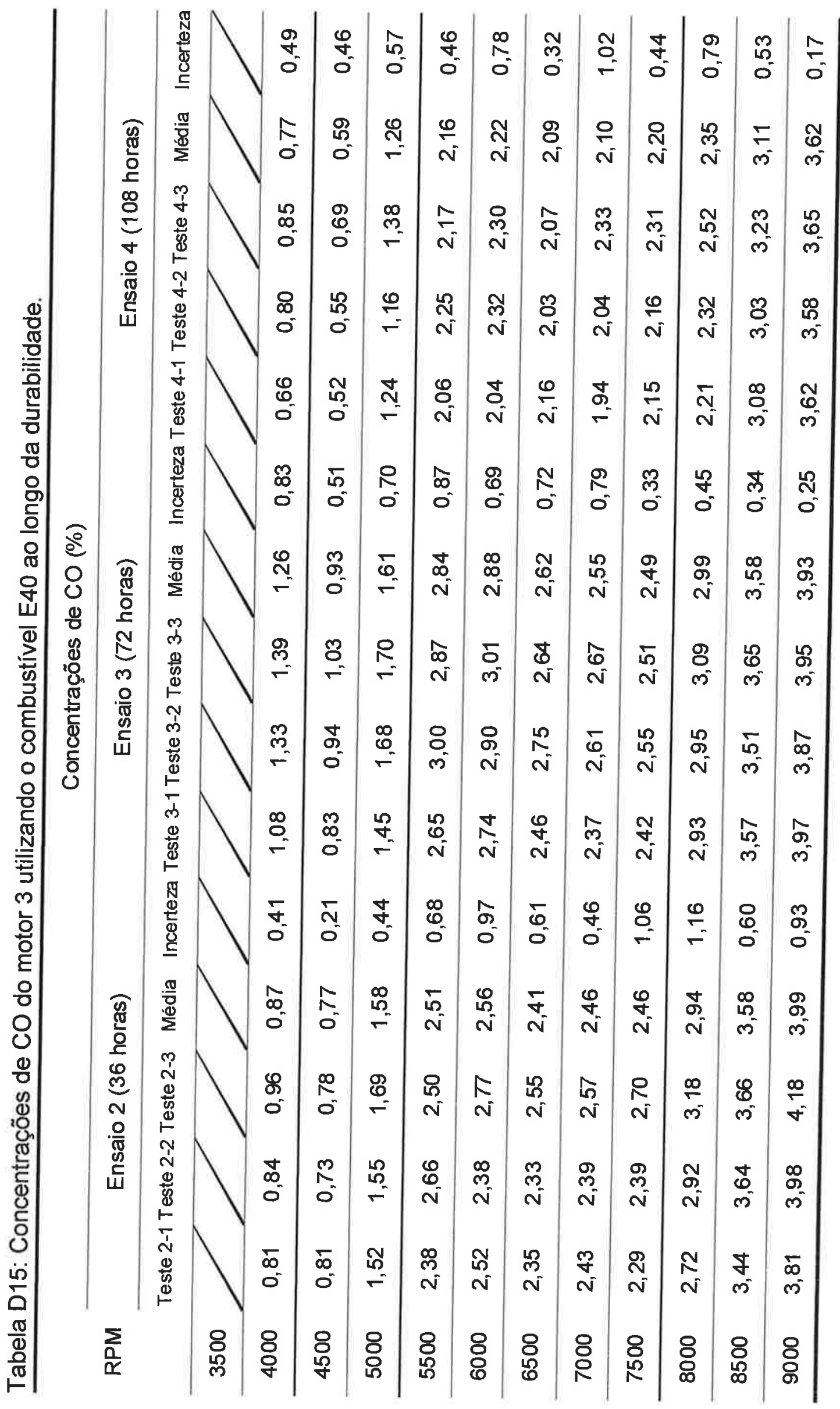




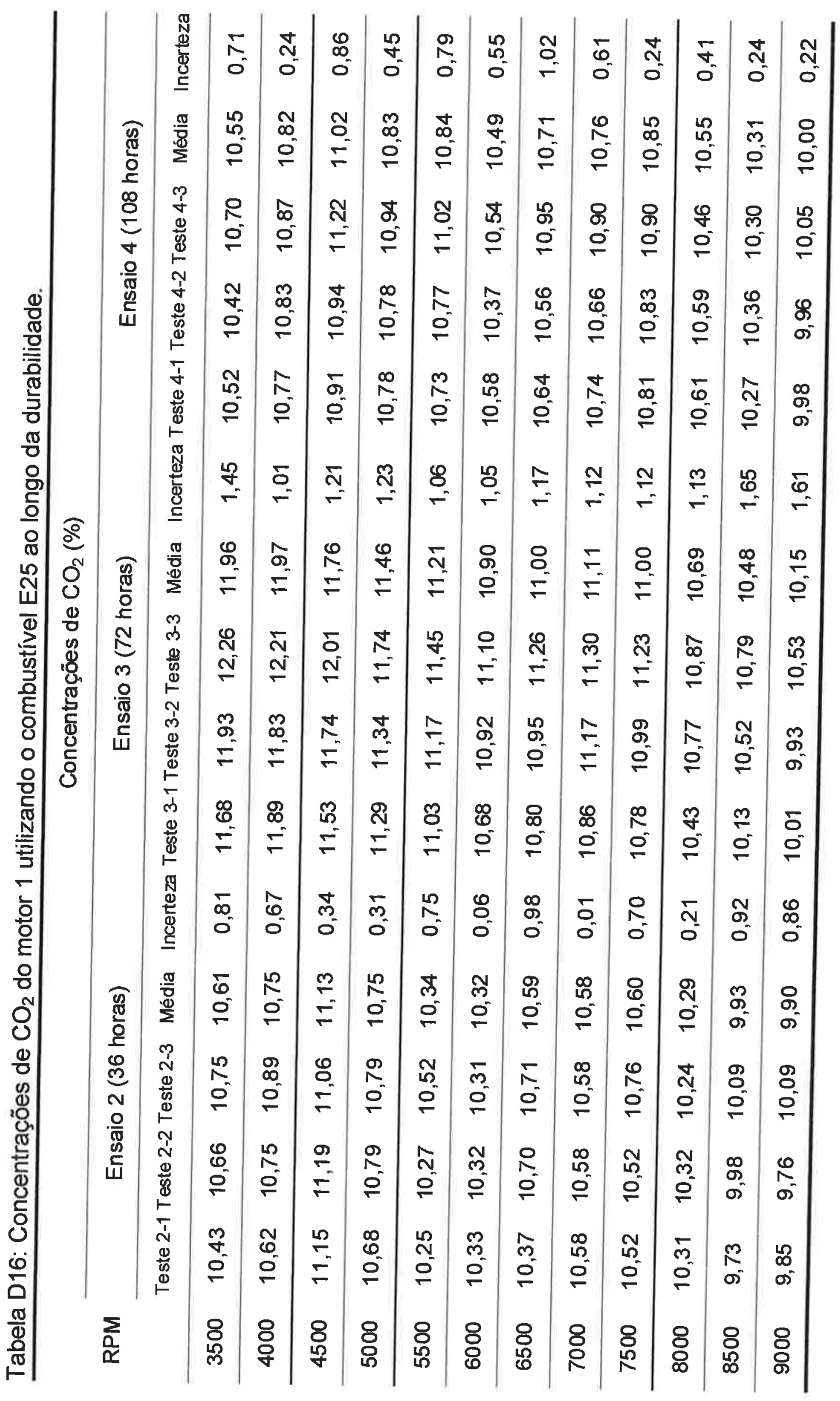




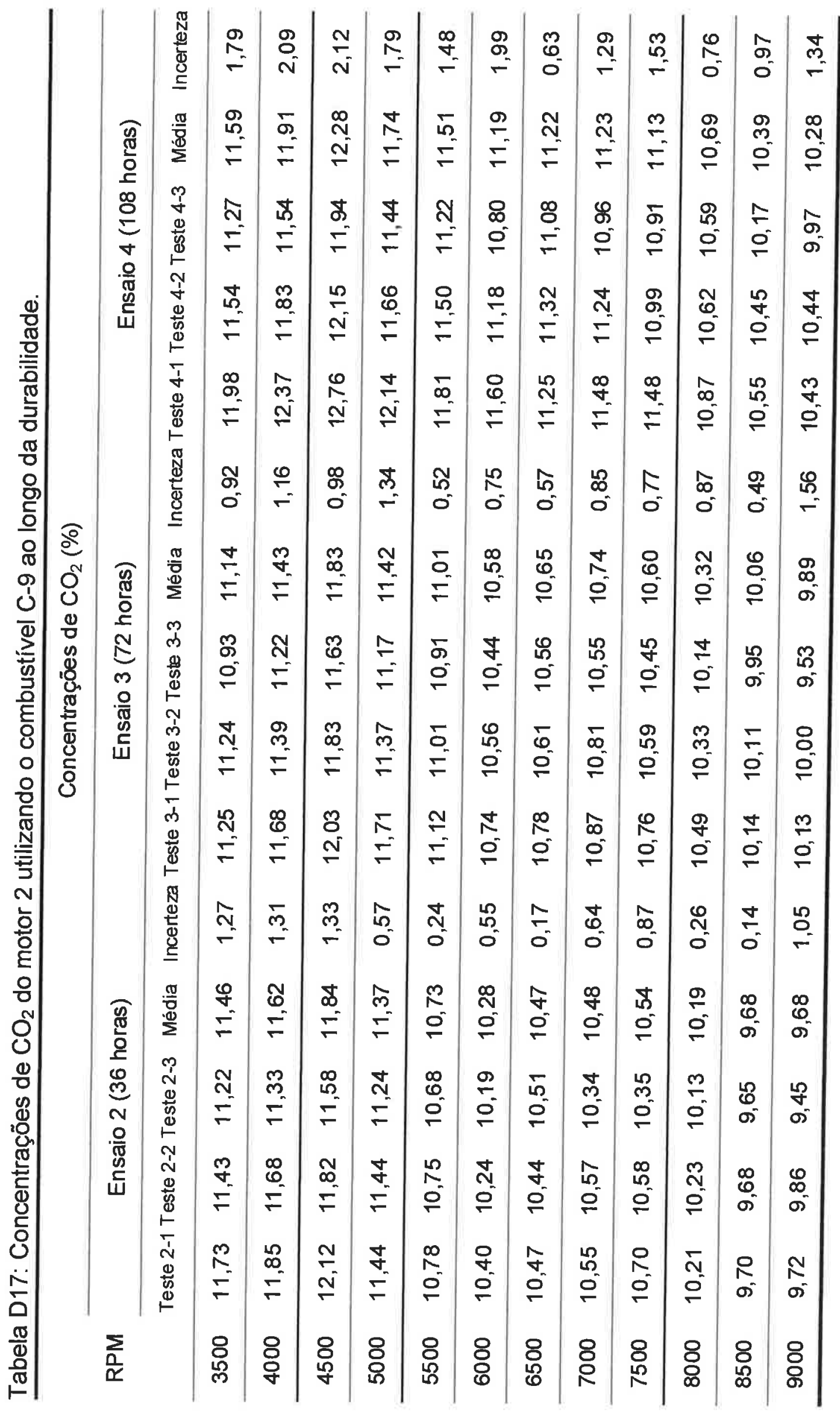




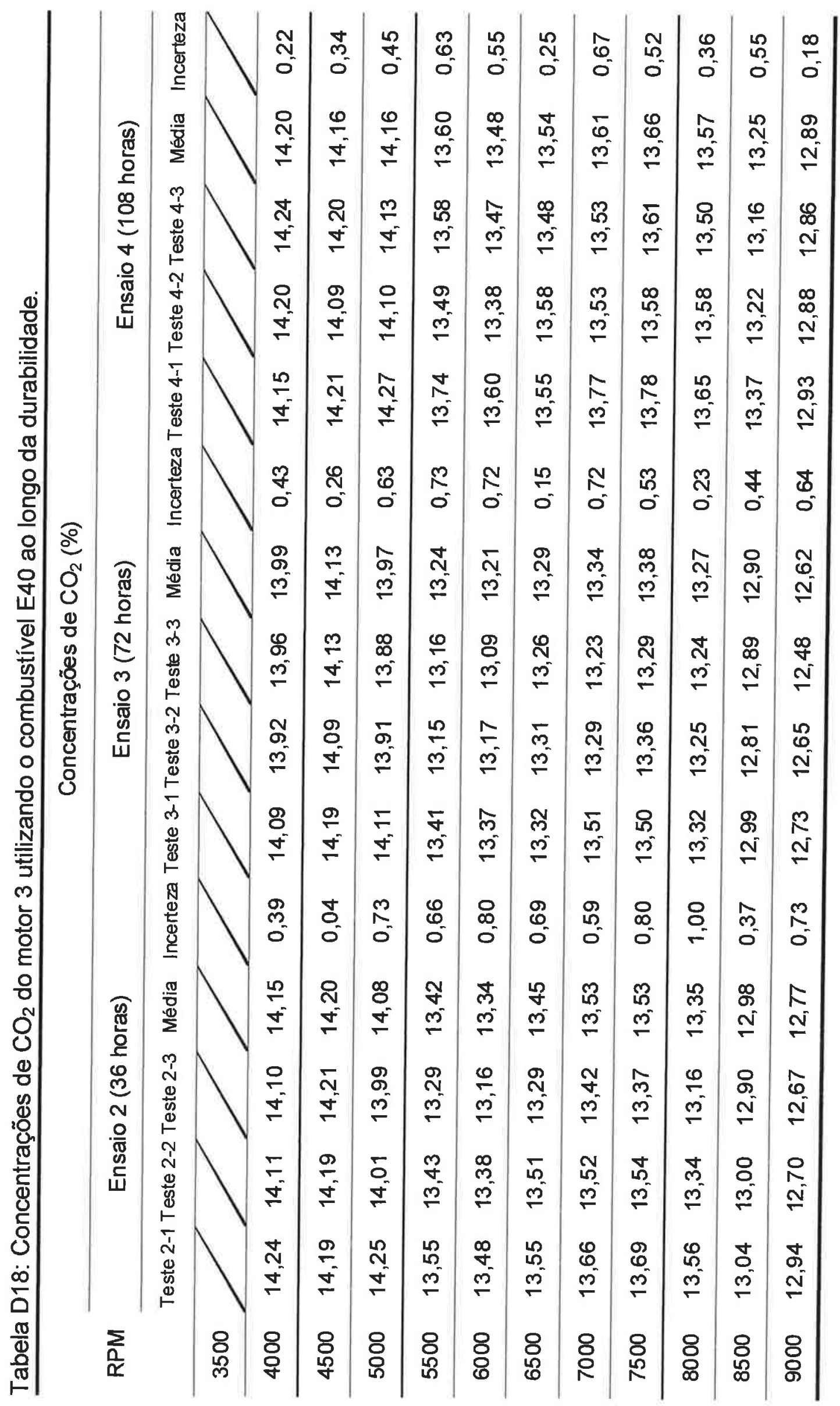




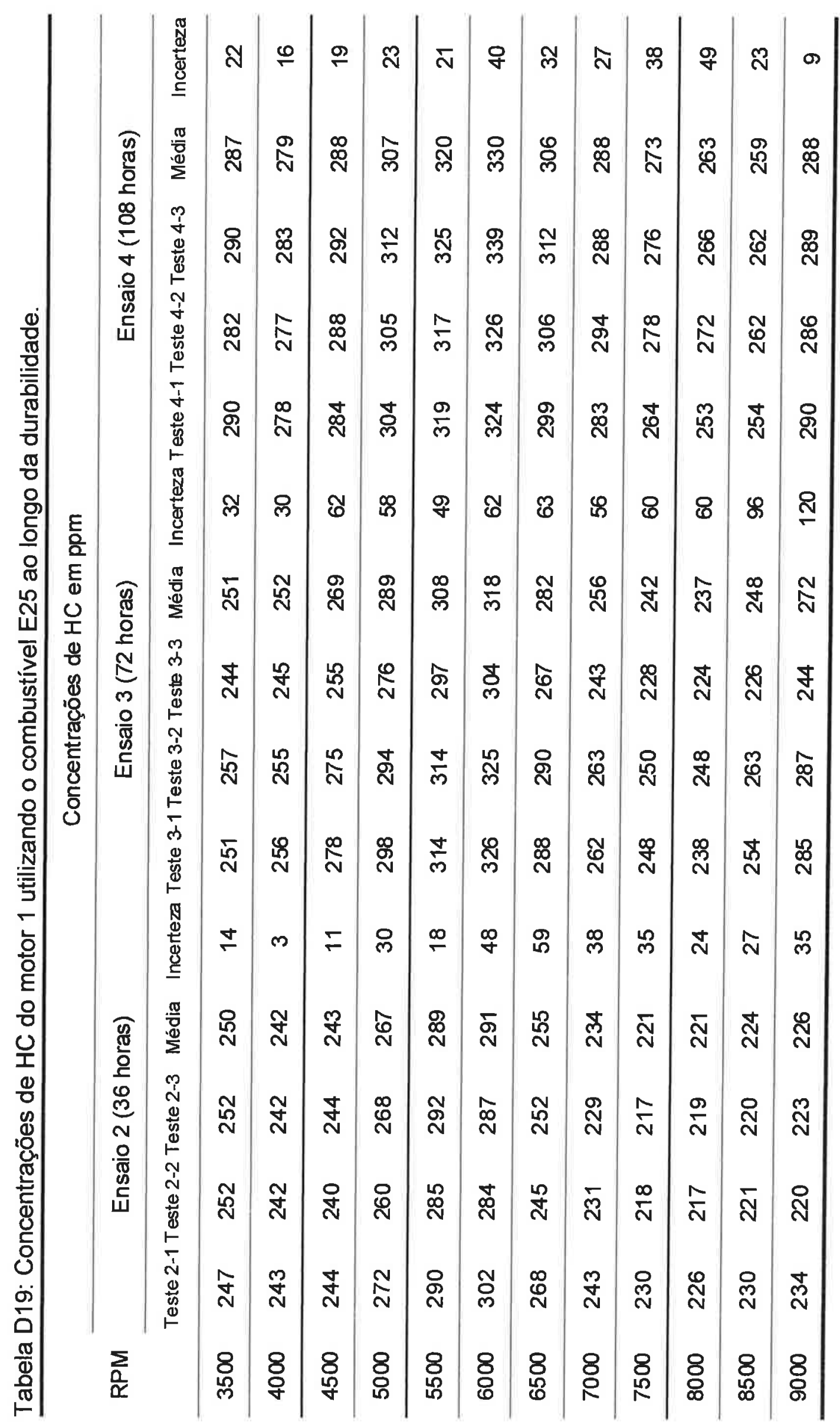


$\forall$

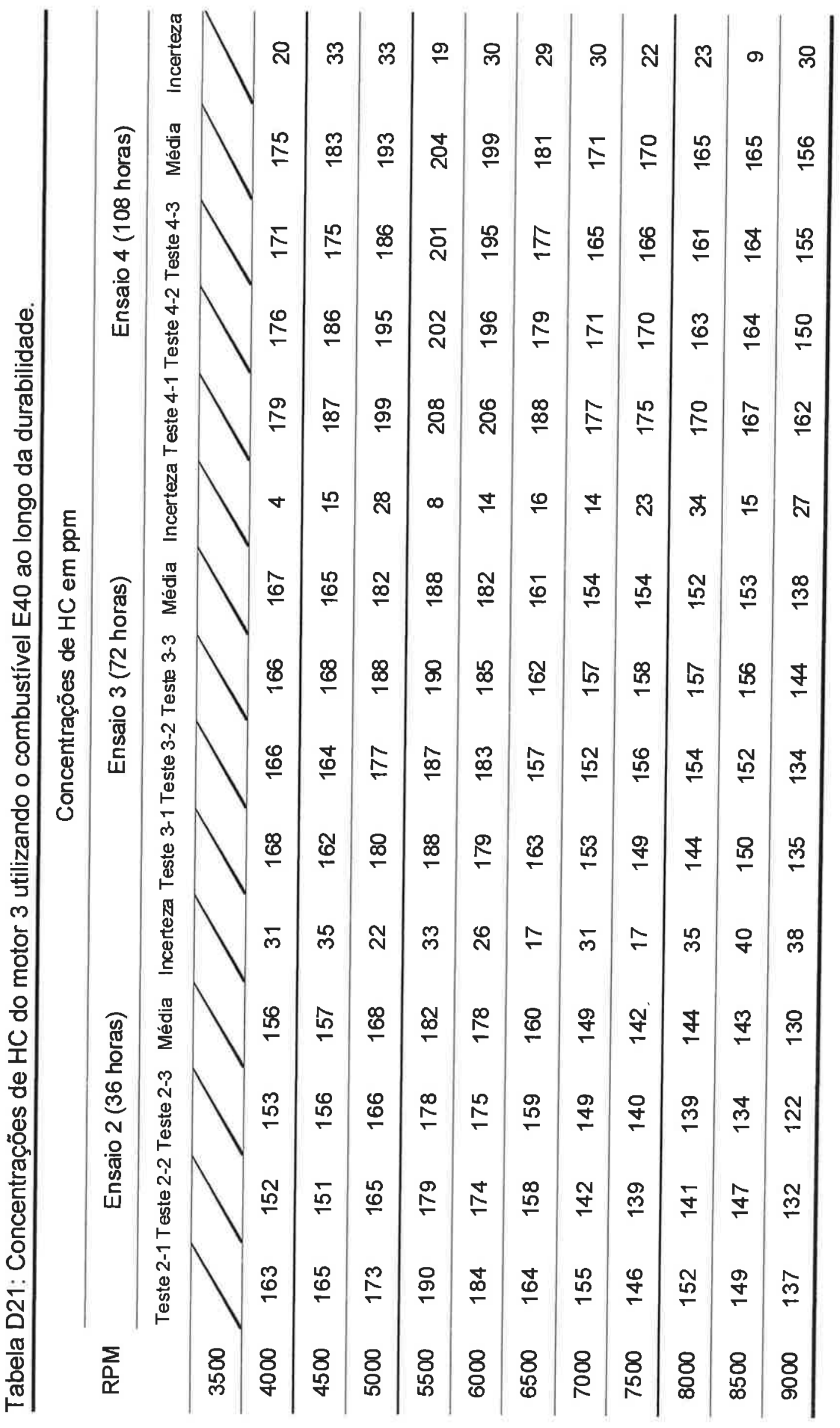




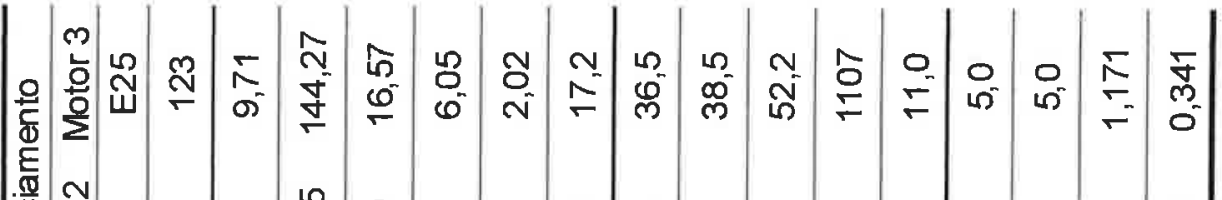

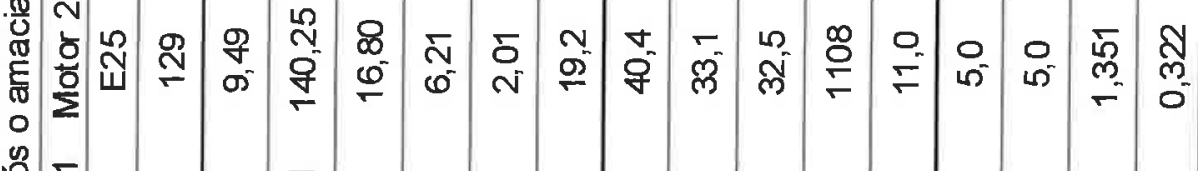

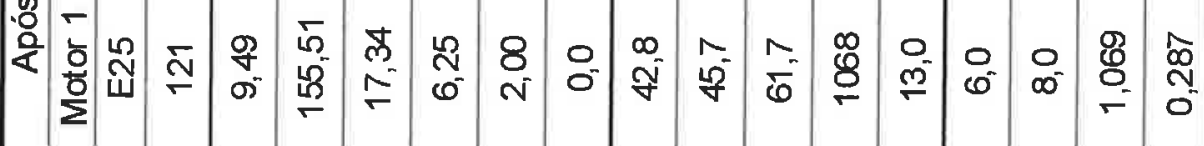

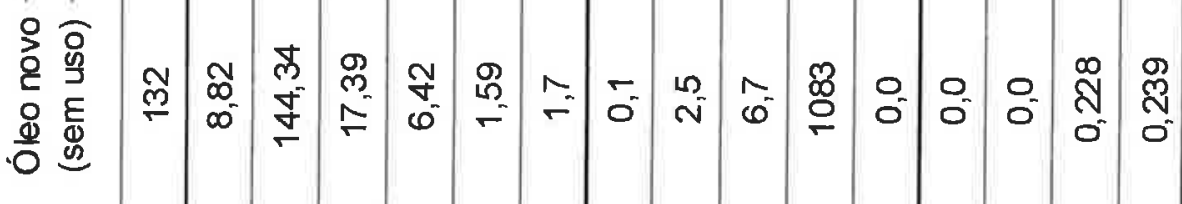

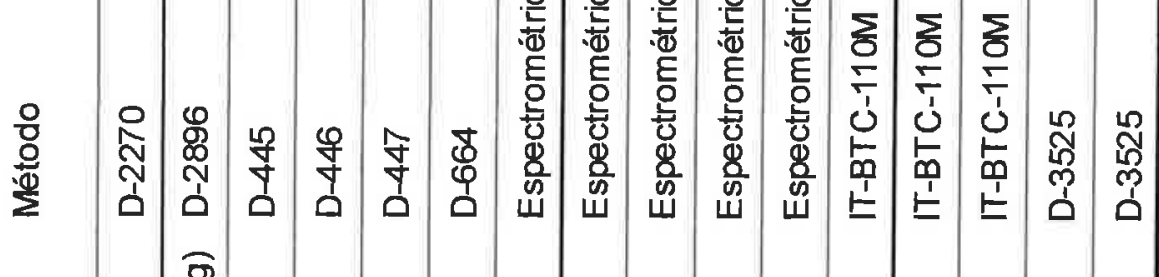

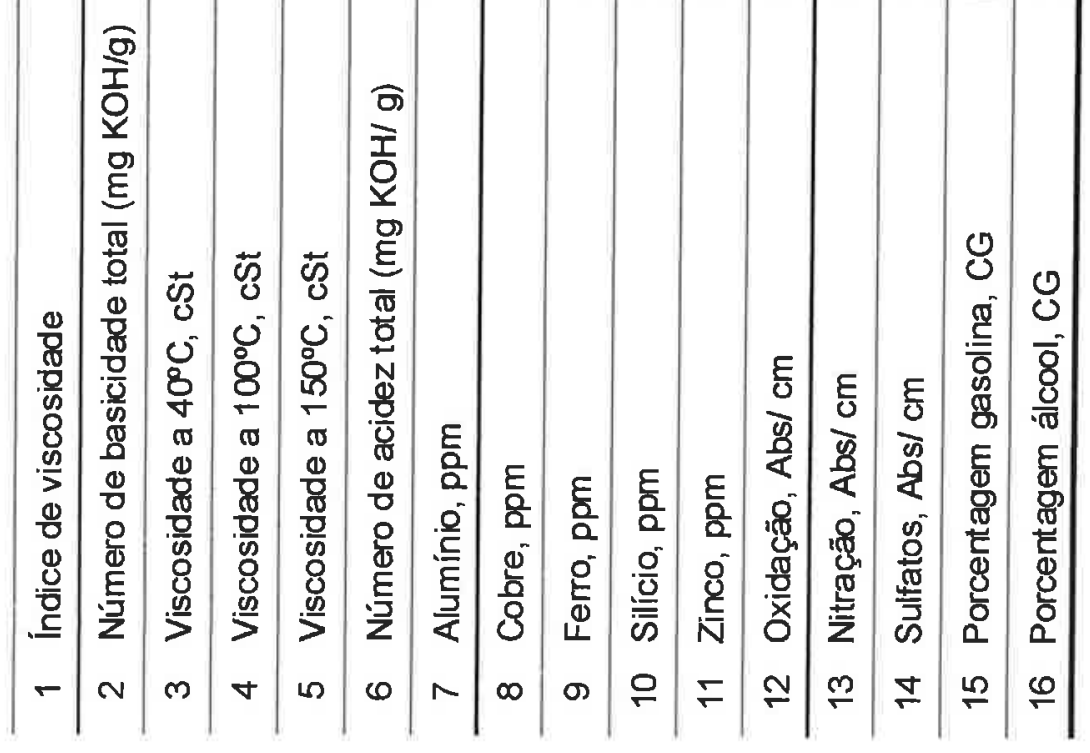


旻

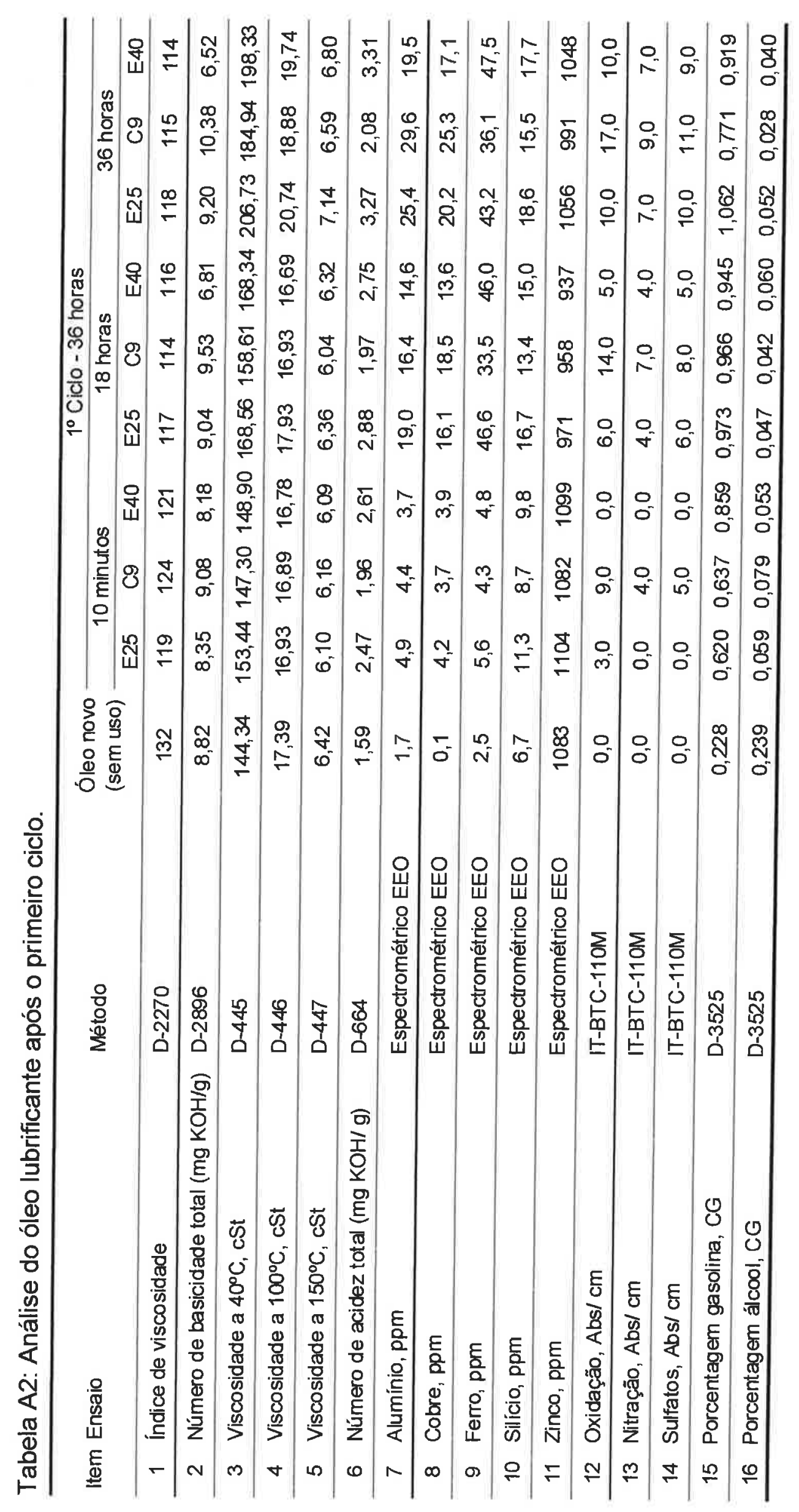




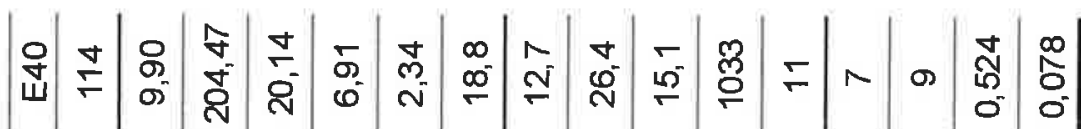

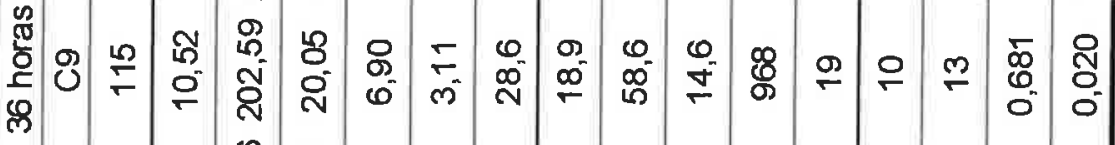
岗

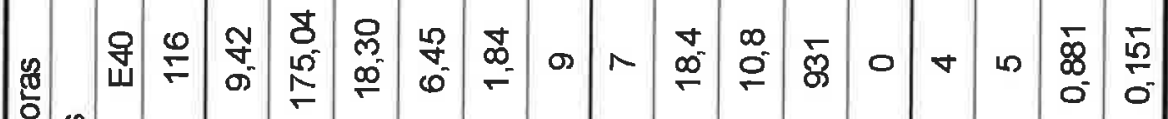

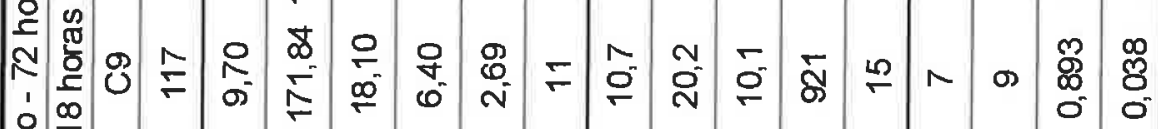
응

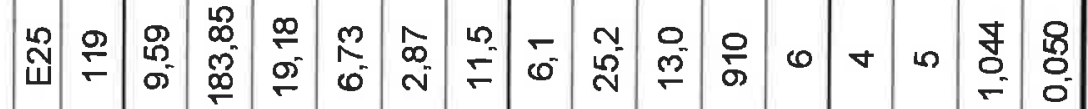

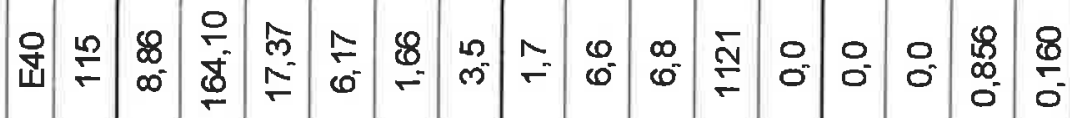

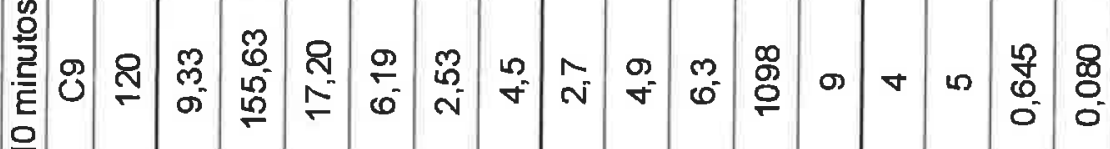

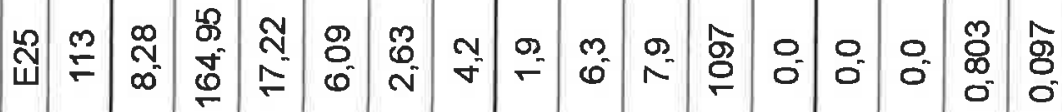

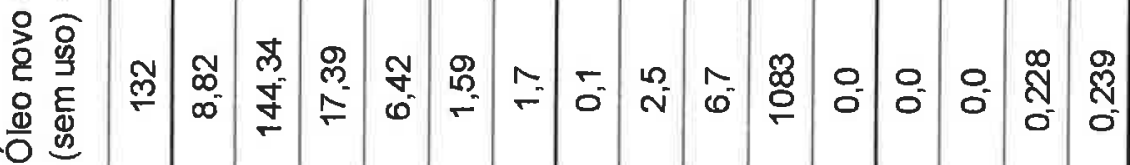

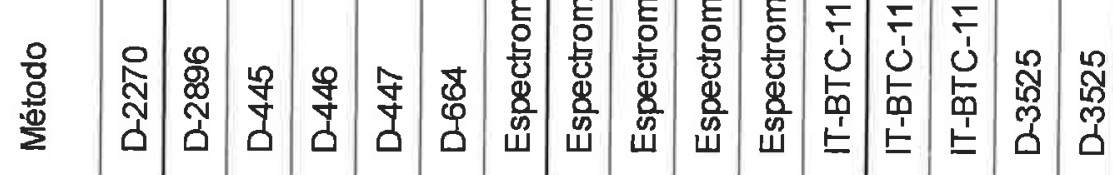

$\stackrel{\Phi}{\rightleftarrows}$

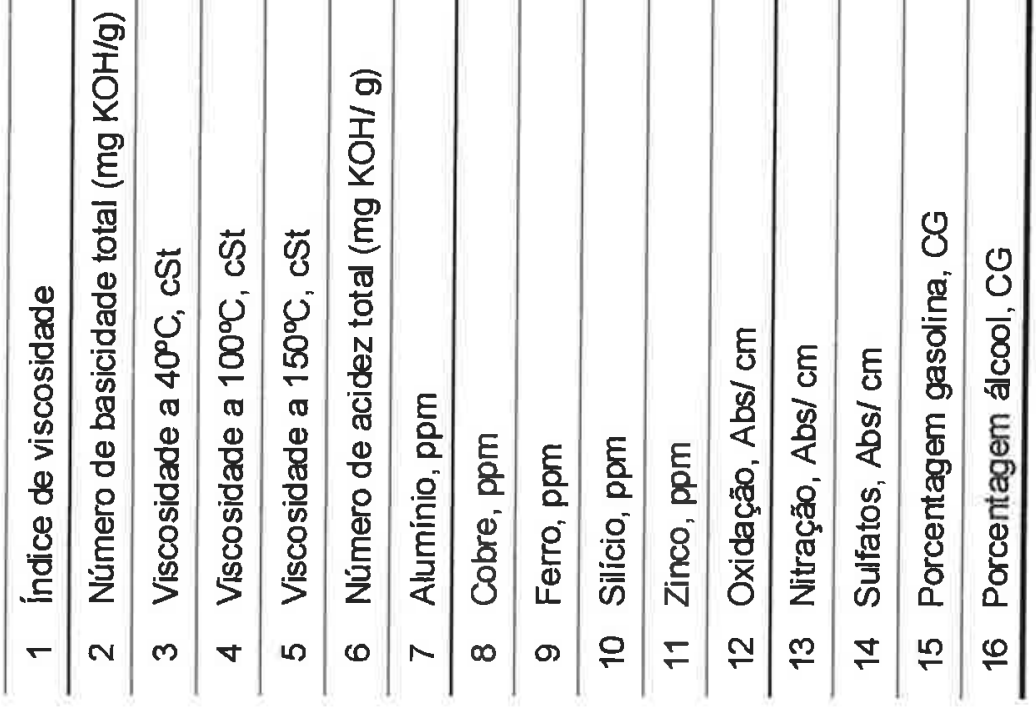


紊

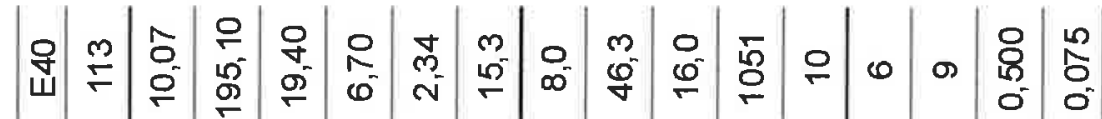

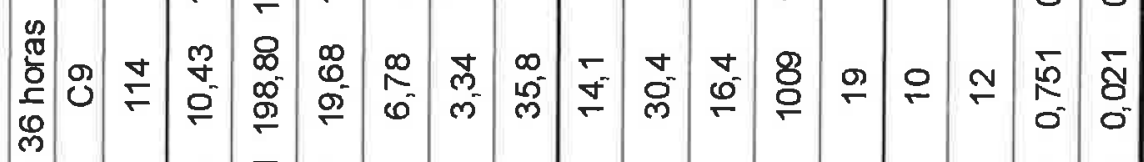

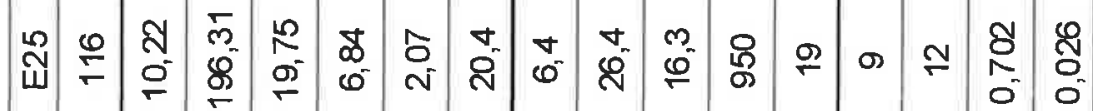

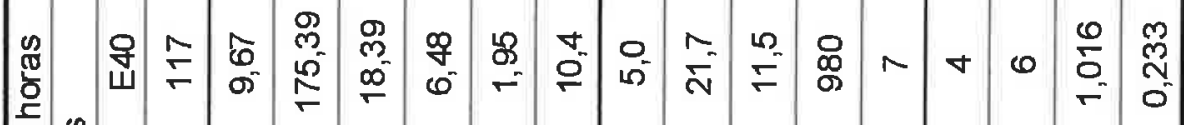

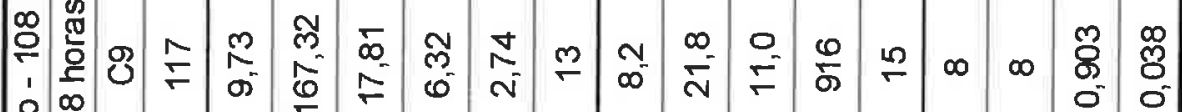
응 -

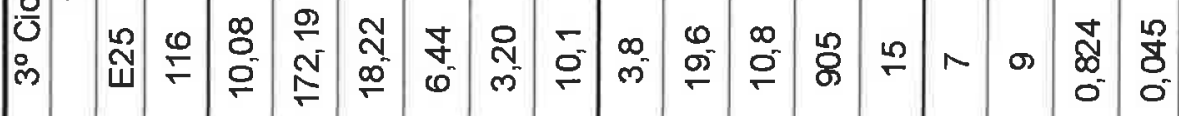

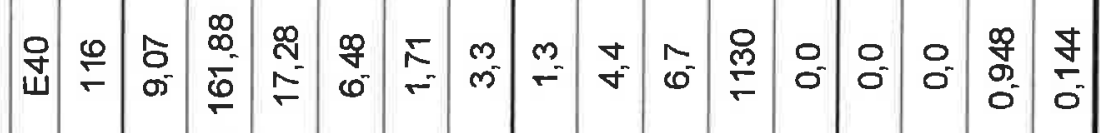

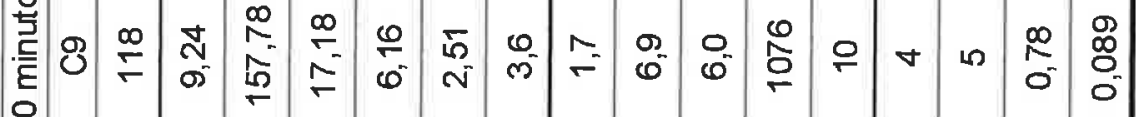
은

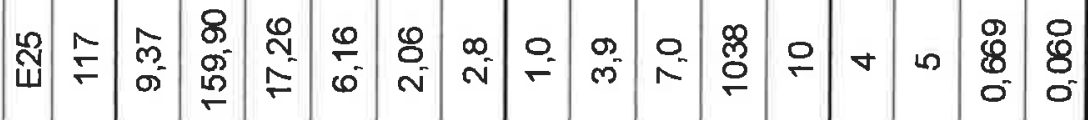

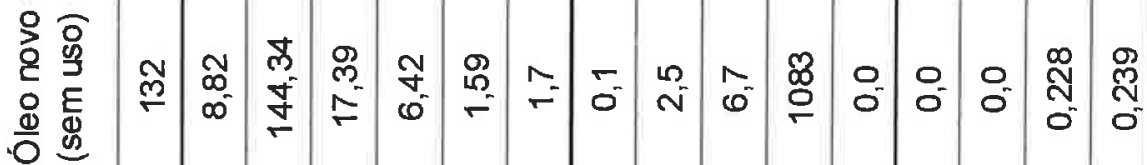

$\frac{0}{0}$

응

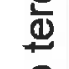

.

논

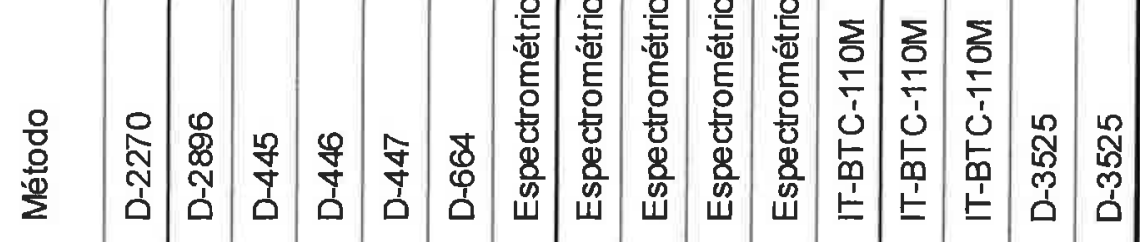

总

$\frac{0}{0}$

응

$\stackrel{.0}{\underline{\underline{m}}}$

产

$\ddot{4}$

$\frac{\pi}{0}$

였였였였

$\circ$ : 8 : 8

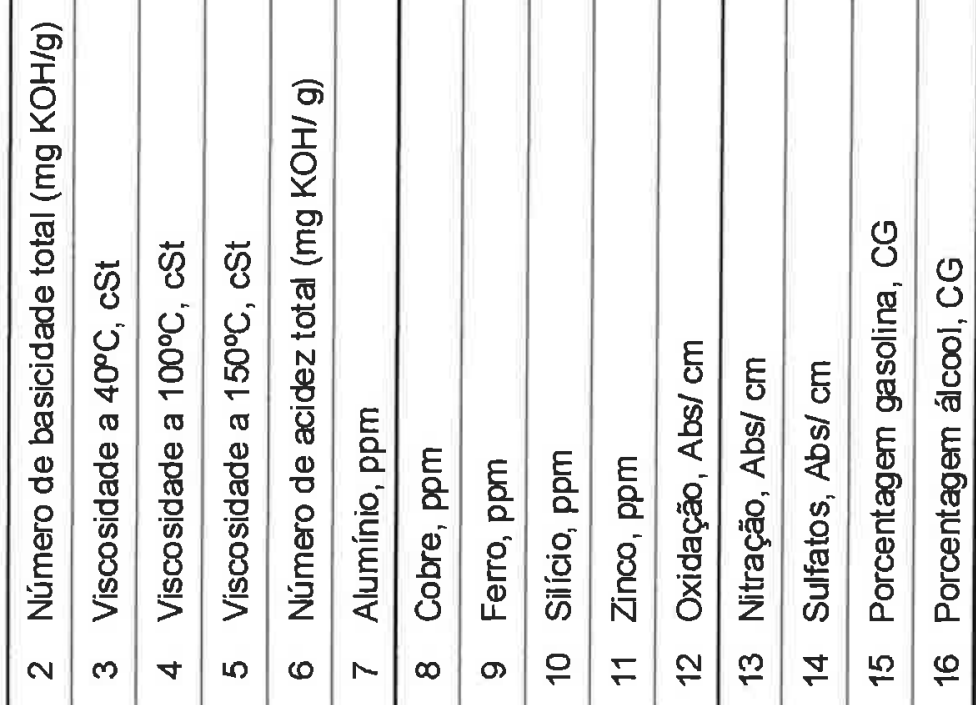

